1978

\title{
The New Orleans riot of 1866 : the anatomy of a tragedy
}

Gilles Vandal

College of William \& Mary - Arts \& Sciences

Follow this and additional works at: https://scholarworks.wm.edu/etd

Part of the United States History Commons

\section{Recommended Citation}

Vandal, Gilles, "The New Orleans riot of 1866 : the anatomy of a tragedy" (1978). Dissertations, Theses, and Masters Projects. Paper 1539623711.

https://dx.doi.org/doi:10.21220/s2-dt1s-dw06

This Dissertation is brought to you for free and open access by the Theses, Dissertations, \& Master Projects at W\&M ScholarWorks. It has been accepted for inclusion in Dissertations, Theses, and Masters Projects by an authorized administrator of W\&M ScholarWorks. For more information, please contact scholarworks@wm.edu. 


\section{INFORMATION TO USERS}

This material was produced from a microfilm copy of the original document. While the most advanced technological means to photograph and reproduce this document have been used, the quality is heavily dependent upon the quality of the original submitted.

The following explanation of techniques is provided to help you understand markings or patterns which may appear on this reproduction.

1. The sign or "target" for pages apparently lacking from the document photographed is "Missing Page(s)". If it was possible to obtain the missing page(s) or section, they are spliced into the film along with adjacent pages. This may have necessitated cutting thiru an image and duplicating adjacent pages to insure you complete continuity.

2. When an image on the film is obliterated with a large round black mark, it is an indication that the photographer suspected that the copy may have moved during exposure and thus cause a blurred image. You will find a gocd image of the page in the adjacent frame.

3. When a map, drawing or chart, etc., was part if the material being photographed the photographer followed a definite method in "sectioning" the material. It is customary to begin photoing at the upper left hand corner of a large sheet and to continue photoing from left to right in equal sections with a small overlap. If necessary, sectioning is continued again - beginning below the first row and continuing on until complete.

4. The majority of users indicate that the textual content is of greatest value, however, a somewhat higher quality reproduction could be made from "photographs" if essential to the understanding of the dissertation. Silver prints of "photographs" may be ordered at additional charge by writing the Order Department, giving the catalog number, title, author and specific pages you wish reproduced.

5. PLEASE NOTE: Some pages may have indistinct print. Filmed as received. 
7904283

VANDAL, GILLES

THE NEW ORLEANS RIOT UF 1866 : THE ANATUMY OF A TRAGEDY.

THE COLLEGE OF WILLIAM AND MARY IN VIRGINIA, PH.D. 1978

\footnotetext{
University

Microfilms

International 300 N. ZEEB ROAD, ANN AABOR, MI 48106
}

(C) 1978

GILLES VANDAL

ALI RIGHTS RESERVED 
The New Orleans Riot of 1866: the Anatomy of a Tragedy

\author{
A Dissertation \\ Presented to \\ The Faculty of the Department of History \\ The College of William and Mary in Virginia
}

\author{
In Partial Fulfillment \\ of the Requirements for the Degree of \\ Doctor of Philosophy
}

by

Gilles Vandal 


\section{APPROVAL SHEET}

This dissertation is submitted in partial fulfillment of the requirements for the degree of

$$
\begin{aligned}
& \text { Doctor of Philosophy } \\
& \text { Filles Condat }
\end{aligned}
$$

Approved, August 1978

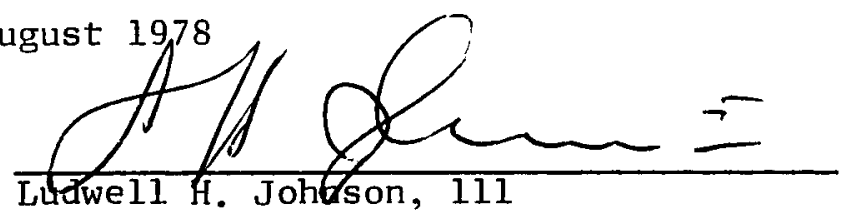

Heles C. Wanker

Helen C. Walker

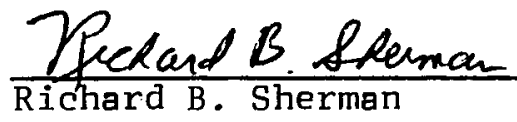

Richard B. Sherman
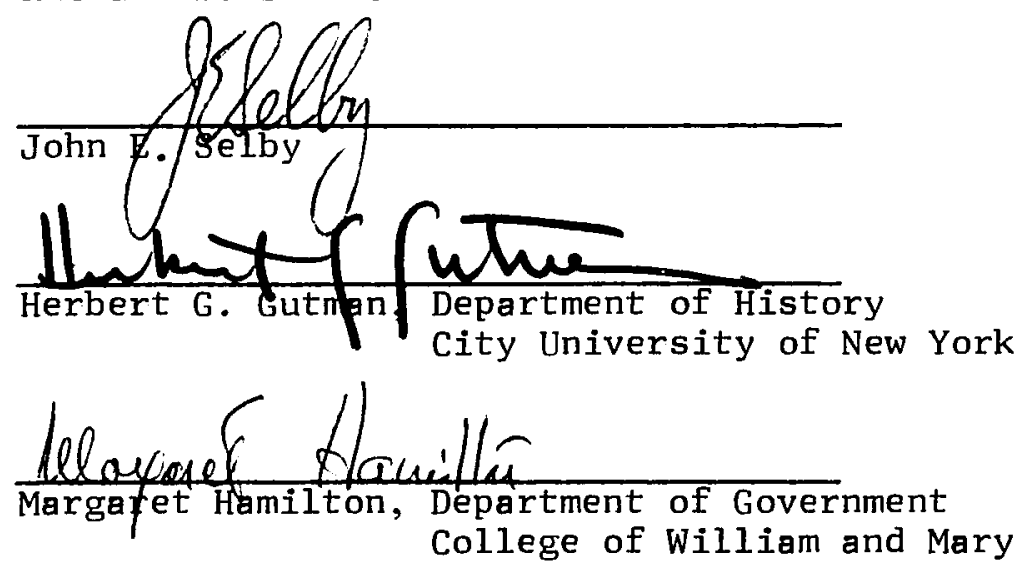
Table of Contents

Page

List of Abbreviations ................... . iv

Preface. . . . . . . . . . . . . . . . . . . v

List of Tables . . . . . . . . . . . . . . . . . .vii

List of Maps . . . . . . . . . . . . . . . . . . . ix

Abstract . . . . . . . . . . . . . . . . . . . x

Chapter I The Genesis of Reconstruction in Louisiana. . . . . . . .2

Chapter II Louisiana under the Hahn-Banks faction. . . . . . . .41

Chapter III Wells' Conservative Policy. . . . . . . . . . . . .78

Chapter IV The Democratic Ascendancy . . . . . . . . . . . 120

Chapter V The Impending Crisis. . . . . . . . . . . . . . 160

Chapter VI The "Bloody Details" of July 30 . . . . . . . . . 214

Chapter VII Crowd and Mob: A World Without Class Distinction . . . 243

Chapter VIII Conclusion. . . . . . . . . . . . . . . . 264

Appendix I . . . . . . . . . . . . . . . . . . 276

Appendix II. . . . . . . . . . . . . . . . . . . . 277

Bibliography . . . . . . . . . . . . . . . . . . . . . . . . . . 


\title{
List of Abbreviations
}

\author{
BRFAL Bureau of Refugees, Freedmen and Abandoned Lands \\ LC Library of Congress \\ LHSL Louisiana Historical Society Library \\ MHS Maine Historical Society \\ NA National Archives \\ NYHS New York Historical Society \\ PHS Pennsylvania Historical Society \\ UNCA University of North Carolina Archives
}


Preface

The New Orleans riot of July 30,1866 , was a grim event, with farreaching consequences for both the city and the nation. Three hours of savage violence had left between forty and fifty blacks dead and more than one hundred fifty others wounded. Federal troops were forced to intervene, and the city was put under martial law. The tragedy shocked the North, helped the Republicans to win a resounding victory in the congressional elections of 1866 , and paved the way for the Reconstruction Acts of 1867 .

Most historians have acknowledged the importance of the New Orleans riot in the history of Reconstruction, and yet, strangely enough, it has never been studied in detail. Historians who have dealt with the subject at all have been confused as to its origins and the nature of the contending parties involved in the riot, and they have failed to employ important sources that are here fully exploited for the first time. In this study, I have attempted to fill a gap in a critical period of American history.

Teaching assistantships from the College of William and Mary and scholarships from the Quebec Government helped to support me during the years of my doctoral studies and to complete my dissertation much sooner than would have otherwise been possible. 
My deepest gratitide goes to Professor Ludwell H. Johnson. His candid criticisms and his understanding of the difficulties confronting a French-Canadian in mastering the English language helped to make this study a reality. I am especially grateful to Professor Johnson for the freedom he left me in developing my own ideas.

I am also endebted to Professor Herbert G. Gutman, under whom I began this study during his year as Harrison Professor at the College of William and Mary. Professor Gutman willingly took time out of his busy schedule to read a draft of my dissertation and to serve on my committee.

I also profited from the comments of Professor Helen C. Walker who served as second reader on my committee. I should acknowledge, too, my indebtedness to Professor James P. Whittenburg for his patience and willing assistance. Finally, I want to thank the other members of my committee, Professors Margaret Hamilton, John E. Selby, and Richard B. Sherman.

Librarians and archivists at the Swem Library of the College of William and Mary, the National Archives, the Library of Congress, and the Public Library of New Orleans were particularly helpful in my search for pertinent sources. 
List of Tables

Page

Table II.1 Voting pattern on the question of black suffrage. . . .48

Table II.2 Occupation of the members of the 1864-1865 Legislature. .58

Table II.3 Occupation of the Participants at the N.E.R.L.

Convention held in New Orleans in January 1865. . . . .62

Table III.1 Occupation of the Delegates at the Republican

Convention of September 1865. . . . . . . . . . 94

Table III.2 Political Affiliation before the War of the

National Democrats. . . . . . . . . . . 98

Table III.3 Occupation of Democratic Members from New Orleans at November 1865 Election . . . . . . . . . . 101

Table III. 4 Civil War Record of New Orleans National Democrats. . 102

Table III.5 Occupation of the Conservative Union Party. . . . . . 104

Table III.6 Civil War Record of New Orleans Conservative

Union Party . . . . . . . . . . . . 105

Table IV.1 Occupation of March 1866 City candidates. . . . . . 141

Table IV.2 Civil War Record of March 1866 City candidates. . . . 142

Table IV.3 Occupation of May 1866 Candidates . . . . . . . . 144

Table V.1 Roles during the Civil War of the Participants in

the July 24 Democratic meeting. . . . . . . . 176

Table V.2 Officeholding in $1850 \mathrm{~s}$ of participants in

July 24 Democratic meeting. . . . . . . . . . 177

Table V.3 Political Affiliation in the 1850 s of the

Participants in the July 24 Democratic meeting. . . . 177

Table V.4 Occupation of Participants in the July 24

Democratic meeting. . . . . . . . . . . 178

Table V.5 Occupation of the Participants at the July 27

Republican meeting. . . . . . . . . . . 179

Table VI.1 Official Report of the Casualties in the Riot . . . . 224 
Table VII.1 Occupation of the White Supporters at the Riot. . . . 246

Table VII.2 Occupation of Members of the White Mob. . . . . . . 254

Table VII.3 Civil War Service of Members of White Mob . . . . . 255

Table VII.4 Previous Service of the Monroe Police of 1866 . . . 256

Table VII.5 Occupation of the Monroe Police Force . . . . . . . 258 


\section{List of Maps}

Page

Map VI.1 Map showing the route of the Black procession

marching to the Mechanics' Institute. . . . . . . .216 


\section{Abstract}

This study focuses on the origins and outcome of the Now Orleans riot of 1866, the evolution and problems of reconstructing Louisiana and the nation during and after the Civil War, and the impact of the division between President Johnson and Congress on Louisiana politics.

The underlying causes of the riot receive special attention. The alienation of the radical element in 1864, the displacement of the Free State faction in 1865 , the resistance of the majority of native whites to any government dominated by outsiders and their scalawag allies, a confused system of civil and military government, the aspirations of the blacks, and divisions over Reconstruction policy at the national level were the main ingredients of Louisiana politics between 1862 and 1866 . All of these factors helped to bring about the riot.

Military necessity had forced General Butler to proclaim martial law for Union-occupied Louisiana in 1862, but political necessity quickly brought the formation of a civil government. This dual system of authority encouraged the development of factions, since martial law remained paramount and each party sought the favors of a new commanding officer in order to remain in or return to power. When they failed to get military support, these factions called upon their allies within the Federal administration or in Congress for assistance. The division between the President and Congress further encouraged that factionalism.

By the summer of 1866 , factionalism had become the main characteristic of Louisiana politics, and compromise between the contending groups had become impossible. Each faction hoped to receive support either from the President or from Congress. The radicals, alienated in 1864 by General Banks' policy, were waiting for Congress to pass a radical reconstruction policy that would overthrow the existing regime in the state. The moderate faction, formerly led by Governor Michael Hahn, which had been ousted in 1865, called upon Congress to support them in their decision to reconvene the 1864 convention as a means of regaining power by enfranchising Negroes. The conservative Democrats, opposed to what they considered an attempt to subvert the state government, asked President Johnson to support them. But the attitude of Secretary of War Stanton, the abdication of responsibility by military officials in New Orleans and their paralysis of civil authority, and the refusal of either side to compromise rendered a collision inevitable.

This study presents a detailed description of the beginning of the riot, its evolution, and its suppression by Federal troops. It also attempts to examine the question of responsibility for the riot. Finally, one of the important points of this study is an analysis of the social, political, and economic characteristics of the participants in the riot. 
The New Orleans Riot of 1866: The Anatomy of a Tragedy 
CHAPTER I

The Genesis of Reconstruction in Louisiana

New Orleans fell under the guns of the Federal fleet on April 25, 1862, and the civil authorities surrendered the city to General Benjamin F. Butler a week later. Military necessity forced Butler to put the city under martial law. However, President Abraham Lincoln was anxious to begin the process of reconstruction, and so the revival of state and local government was a matter that immediately confronted both the conquerors and the conquered. Unfortunately, the loyal element in Louisiana could not agree on a common program of restoration; dissension appeared especially over the questions of emancipation and black suffrage. This factionalism was partly caused by the different commanding officers in the Gulf Department who could not agree on a permanent policy and who favored now one faction, now another. The restoration of civil government would be a long and painful process.

The first problem that General Butler met was the maintenance of public peace and order. Between the city's surrender to the Federal fleet and its actual occupation by the Union army a week later, New Orleans had lived under mob rule. This led General Butler to proclaim martial law on May 1, the day after he took control of the city. This proclamation, which would remain in force until President Andrew Johnson declared the war officially ended on August 20, 1866, 
brought to Louisiana and New Orleans a confusion of authority. ${ }^{1}$ This confusion originated from the partifular aspect of the application of martial law in a civil war, since the purpose of the occupation was to destroy Confederate rule and restore these states to the Union. Therefore, the military commander of a conquered region could not simply consider the territory as an occupied region, but had also to pursue a policy that would bring the local population to support the Union. The formation of Union organizations and of a civil government that would cooperate with the military authority was naturally an important subject of concern for President Lincoln and the commanding officers of the military departments in the south. ${ }^{2}$ Such considerations persuaded Butler to allow the civil officials of the city to perform their usual functions. But this division of authority between civil and military authorities lasted only two weeks, because of the unwillingness of the city officials to cooperate under the terms imposed by Butler. Therefore, on May 17, 1862, General George F. Shepley, a Democrat from Maine and a protege of Butler, who was already military commander of the city, superseded John T. Monroe as Acting Mayor of New Orleans. ${ }^{3}$

Almost immediately after the capture of New Orleans, President Lincoln saw the necessity of establishing a loyal civil government as a first step in the restoration of Louisiana to the Union. This was the main motive that justified his appointment of General Shepley as Military Governor of Louisiana in June 1862 , as a step toward taking civil affairs out of the hands of the commanding officer of the Department. Meanwhile, Butler, realizing that the development of Union sentiment would make his task easier, ${ }^{4}$ took measures to encourage its growth among the New Orleans population. He encouraged the formation of Union 
clubs. He favored the class interest of the poor and laborers who formed a majority of its population by granting them special measures of relief, while taxing the uppser class. He also required people either to take an cath of allegiance or to register themselves as enemies of United States. Finally, he vigorously enforced the confiscation act of July 1862. The appeal of Butler seemed to work well, since 11,000 people had taken the oath of allegiance by September 1862 and a Union Association had been formed in New Orleans as early as June 1862. 5 Such prominent citizens as Thomas J. Durant, J.A. Rozier, Jacob Barker, Thomas J. Earhart, Anthony Fernandez, Christian Roselius, and two unionists just back from exile, A.P. Dostie and Benjamin F. Flanders, were playing an active role in developing Union support in the city. The New Orleans Union Association had enough strength to hold on July 4 a large mass meeting. ${ }^{6}$ However the development of a strong Union party seemed to be checked by the question of slavery. These early unionists were ready to support a restoration of the state, but most of them still favored restoration on the basis of the 1852 constitution. In other words, they wanted to return to the ante-bellum situation. Consequently, the question of slavery became almost immediately a central issue in the development of a policy of restoration. 7

The arrival of the Union army in New Orleans had of itself hastened emancipation. Although Butler, as a means of maintaining order and preventing unrest, had allowed the provost marshals and the city police of New Orleans to search for and return runaway slaves to their masters, blacks increasingly took refuge in New Orleans in the summer of 1862 . By the fall of 1862 , the problem had become overwhelming. It was reported that more than 10,000 blacks had left the plantations for the 
city. This problem was aggravated by the fact that the military authorities employed blacks in great numbers. Although the policy was to employ only free blacks, the army had no way of checking their status and therefore accepted the assertion of the black workers that they were free. ${ }^{8}$ Moreover, fear of slave insurrection was fed by what whites saw as repeated acts of violence committed by slaves. On at least four occasions during the summer of 1862 groups of runaways clashed with city police in street battles, giving rise to rumors of a slave insurrection. These disturbances constituted, of course, a serious warning to the white population, demonstrating clearly the difficulty of holding biacks in bondage any longer and demonstrating also the readiness of some blacks to fight for freedom and equality. ${ }^{9}$ Finally, the shortage of troops in Louisiana and the suggestion of Secretary Stanton would bring General Butler to encourage the enlistment of black soldiers by the end of the summer of 1862.10

Those events were closely followed by the white population and would bring a thorough Unionist such as Thomas J. Durant to complain to the military authorities about the growing nunber of fugitive slaves, 11 while others such as George S. Denison, ${ }^{12}$ Jacob Barker, ${ }^{13}$ and Reverdy Johnson $^{14}$ saw in emancipation a threat to the development of any Unionist movement in Louisiana. ${ }^{15}$ Therefore, they all agreed that the federal administration must establish a clear policy on that question. They also wanted Washington to condemn General John W. Phelps for granting liberal protection to the "contrabands" inside the Union lines. ${ }^{16}$ Clearly, Loulsiana did not seem ready for emanclpation. However, the question of emancipation was transformed by Lincoln's preliminary Proclamation of Emancipation. 
President Lincoln had at first disclaimed any intention to interfere with slavery, but by the summer of 1862 new political and military factors brought him to change his views. Those factors were as diverse as the development in Congress and within the Federal Administration of a "war mind", the widening of the purpose of the war, the pressure of the foreign situation which called for a more definite policy on slavery, the need for more troops, the desire to create disorder within the Confederacy, the necessity of pacifying Northern radicals, and the plain practical problem of administrating the occupied territory. ${ }^{17}$

President Lincoln had specified in his preliminary proclamation that a final Proclamation of Emancipation would follow on January 1, 1863, if the Confederate states had not meanwhile resumed their allegiance to the national government. In his proclamation of January 1, 1863, President Lincoln declared free all persons held as slaves in the rebellious states, but he exempted the border states and areas under the control of the Union troops. In one sense, Lincoln's proclamation complicated problems in Louisiana, since the portion of the state controlled by the Union army was excluded from the Proclamation. ${ }^{18}$ For that part of the state, it was as if no proclamation had ever been issued. Local police regulations had not been removed and could still be enforced by provost marshals. In January 1863 , the white population of those parishes was still asking and expecting the enforcement of existing pre-emancipation laws and regulations in order to prevent trouble. ${ }^{19}$ Beyond this, planters began organizing their own party to fight for the continuation of slavery. The spirit of slavery was far from dead. The final abolition of slavery in Louisiana would have to await the military order of 
General Banks on January 11, 1864. That decision was ratified by the constitutional convention of 1864 and by the adoption of the 13th amendment in 1865 .

Following the preliminary proclamation of emancipation, discord appeared among Unionist circles. A more radical group, which had the support of General Butler and Governor Shepley and which controlled the Union Associations, began to advocate the restoration of Louisiana with emancipation. Meanwhile, another group, more conservative, hoped that a quick restoration of Louisiana under the 1852 constitution would exempt the state from the conditions of the Emancipation Proclamation. This division between unionists became apparent during the congressional election of December 1862, which had been ordered by General Butler at the request of the Federal administration. President Lincoln hoped that the election of representatives for the two congressional districts under the Union control, followed by the establishment of a loyal state government, could bring a quick restoration of Louisiana to the Union and open the way to the reorganization of the other Southern states. 20

There were four main contenders for the two seats. Edmund H. Durell, a prominent lawyer, and Benjamin F. Flanders, a former railroad administrator, represented the two "Simon Pure Unionists" candidates supported by the Union Association, while Jacob Barker, a wealthy young banker, and $\mathrm{Dr}$. Thomas Cottman entered the race as independent candidates representing the more conservative unionist element. In the midst of the canvass, General Butler forced the popular Dr. Cottman to withdraw from the race. The conservatives replaced him with the moderate Michael Hahn. On the day of the election, the voters (people who had taken the oath of 
allegiance) gave an easy victory to Benjamin F. Flanders over Jacob Barker for the seat of the First Congressional District, while they gave an overwhelming victory to Michael Hahn over E.H. Durell in the Second. The two congressmen-elect proceeded to Washington in early December. Both were allowed to take their seat for the remainder of the session, which ended in February 1863. 21

The Proclamation of Emancipation of January 1, 1863, gave the Union Association new vigor and a program under which the state could be reorganized. The removal of General Butler, necessitated by the protests of the foreign consuls of New Orleans, did not at first affect the Union Association. Although General Nathaniel P. Banks, a former Republican governor of Massachussetts and Speaker of the House of Representatives, who superseded Butler in the Gulf Department in 1862, adopted a more conservative policy than his predecessor, this did not immediately affect the process of reorganization and did not prevent the radical wing of the Union Association from adopting a policy which would make Louisiana a free state. For most of the year 1863, the Union Association would have the support of Governor Shepley, a Butler protege who was responsible for the civil affairs in Louisiana. ${ }^{22}$

The rejection by the Union Association of the 1852 constitution as a basis for reorganizing the state and its evolution into a Free State Association would occur in the spring of 1863, after Thomas J. Durant had become a leading figure in the Union Association. Durant, who had headed the cooperationist party in 1860, was already known before the war as a talented orator and a shrewd politician. Family sickness and a trip to the North during the summer 1862 explained his slowness in 
becoming an active member of the Union Association. Still, Durant did not remain completely inactive in 1862. He was the principal orator at a Union meeting held on November 15, $1862 .{ }^{23}$ Moreover, by the fall of 1862, he had become a close associate and adviser of General Butler. 24 On February 28, 1863, he attended his first Union meeting as a full member. He maintained that the reorganization of the state and preparation for a constitutional convention should go hand in hand. Durant also specified that at the election for the delegates to the convention and at the following one on ratification only unequivocal unionists who had taken an oath of allegiance should be allowed to vote. ${ }^{25}$ The plan suggested by Durant was well received by the members of the Union Association. They named a study committee to report to the Association at its next meeting ${ }_{n}^{\text {in }}$ March 7, 1863. On that date, the committee recommended favorably, and Durant's proposal of calling a constitutional convention was adopted unanimously. By then, in spite of objections of conservative unionists who favored the restoration of Louisiana under the 1852 constitution, the formation of a constitutional convention had becume the central goal of the Union Association. 26 Durant had become the impelling spirit of the Union Association, and he was ready to push its members in a radical direction.

By the beginning of May 1863, Durant had succeeded in combining the Free State Association and Union Association into one instrument to implement his plan for a constitutional convention. A General Executive Committee of the Free State Association was created, and Durant elected its president on May 8, 1863. Thereafter, the General Executive Committee held regular meetings to study Durant's design for holding a convention. 27 After two weeks of debates, mainly about the question of a 
new registration of voters, Durant's plan was adopted. Its provisions were: first, a new registry was to be ordered; second, only those citizens who had taken an oath of allegiance could be registered; third, there would be one delegate for each 2500 citizens, based on the 1860 census; fourth, the convention was to meet in New Orleans no more than sixty days after the election; fifth, the new constitution was to be submitted to the voters; and finally, after the ratification of the new constitution, the military governor was to order an election for state officers. ${ }^{28}$ The General Executive Committee also passed a resolution asking Durant to call upon General George F. Shepley, the military governor of Louisiana, and to submit its plan to him. ${ }^{29}$

Durant had already informed General Shepley of the evolution and intention of the General Executive Committee in a letter of May 8, 1863. He wrote Shepley again at length on May 21 and May 23, asking his advice and support on the questions of the basis of representation of a new registration. ${ }^{30}$ On May 25 Shepley replied to Durant, giving him full support. The military governor offered to collaborate in effecting the resolutions of the General Executive Committee and expressed his readiness to nominate the committee's candidates as commissioners of registration in the various districts and parishes of the state. Shepley went further, specifying that the questions of an oath and the basis of one delegate for 2500 citizens should be decided by the people themselves, rather than by any military authority. Finally, Shepley added that he preferred to leave the restoration of the state in the hands of the people and to avoid any military interference. 31 This response marked the beginning of a close relationship between Shepley and Durant. Early in June Shepley kept his promise by appointing persons recommended 
by the General Executive Committee as commissioners of registration for the parishes of New Orleans, Jefferson, Terrebonne, and Lafourche. On June 12 he appointed Durant as Attorney General and Commissioner General of Registration of Voters for Louisiana. ${ }^{32}$ This last decision solved the administrative problem of communication between the military governor and the Union Associations.

Meanwhile, on February 18 and 19, 1863, a group of planters had held a convention in New Orleans to discuss the subject of police juries, which promulgated regulations concerning vagrants, runaways and so forth, and to press General Shepley for a solution to that problem. ${ }^{33}$ In a letter to Shepley, written on April 19, 1863, J.Q.A. Fellows, a prominent lawyer and planter from Jefferson City, expressed the increasing anxiety of the planter and commercial class about the growth of the Union Associations of New Orleans and their expressed desire to make Louisiana the first free southern state. Supporting the view that the 1852 constitution was the fundamental law of the land, Fellows therefore opposed the assembling of any convention. The state, he said, could be restored to the Union only if the military governor called for an election in November to put "the machinery of the State \& Municipal Government into full \& effective operation." 34 In order to press those ideas on the Federal Administration and to check the growth of the Free State Association, the planters held a meeting in New Orleans on May 1, 1863. Three commissioners, E.E. Malhiot, Braddish Johnson, and Thomas Cottman, were chosen to visit Washington and present to the President the views of the loyal planters of Louisiana and ask him to restore Louisiana "to its full allegiance in the enjoyment of all rights and privileges exercised by the other States under the Federal constitution."35 
The three commissioners had an interview with President Lincoln on June 12 , but they failed to get any commitment from him. Indeed, Lincoln knew of the increasing importance of the Free State Association and the expressed desire of a "respectable portion of the Louisiana people. - . to amend their State Constitution" by means of a convention. As Lincoln said, "This fact alone, as it seems to me, is a sufficient reason why the General Government should not give the committal you seek, to the existing State Constitution." 36 The decision of President Lincoln greatly encouraged the Free State members. James E. Dunham, the sheriff of the Parish of New Orleans, wrote to Shepley:

Have you seen our good President's reply to that (selfconstituted) committee of planters from this State, consisting of Cottman, Johnson \& one other? Such reply, to such a party, is it not good? Is it not refreshing? Should you meet Doctor Cottman you may prepare to hear something about the ingratitude of republics? 37

By July 1863, the movement for reorganizing Louisiana was slowing down. Durant and his followers discovered that the registration of a large number of voters, development of a state-wide political apparatus, and gaining military control of a large part of the state would demand more time and work than they had first thought. Moreover, General Shepley's journey to the North and a severe inflammation of his eyes prevented Durant from doing anything during the months of August and September. ${ }^{38}$ Still, Secretary Stanton had given the Free State Association permission to pursue its policies by ordering General Shepley on August 24 to register all the loyal citizens of Louisiana along the lines drawn up by Durant. 39

In spite of Stanton's order in August, the work of reorganization was further delayed by a controversy over the right of the planter party 
to call a state election for the first Monday of November. That party had held a preliminary meeting on Szptember 18 and 19, and had decided to go forward with its project despite Shepley's opposition. Although they had deliberated secretly, the rumors that began to circulate brought protests from Union circles. ${ }^{40}$ And while it is important to note that the conservative group by holding its election and seeking admission to Congress came close to succeeding in its project, ${ }^{41}$ the main significance of the controversy was the rupture between Shepley and Banks, leading the latter to change his attitude toward Durant in January 1864. When the rumor arose that General Banks was supporting the conservative movement for a state election, Shepley and Durant called upon General Banks for an explanation. Moreover, Shepley and Durant told Banks that a direct order of the Secretary of War had put the reorganization of Louisiana under the control of the military governor and not under the commander of the Gulf Department. Banks replied that the Administration could only with difficulty suffer further postponement and that there was a need to move more quickly on Reconstruction matters. ${ }^{42}$ Thereafter, Banks began to work against Durant in an attempt to build his own party.

By the end of fall 1863, no reorganization had been accomplished in Louisiana, and President Lincoln was fast losing patience. In October he had received a letter from Durant informing him that there had been no registration of voters, and he had been visited by Hahn and Flanders, who told him that Union men in Louisiana did not think it appropriate to proceed further until there was more territory under the control of Union troops. Lincoln replied that "he would recognize and sustain a state government organized by any part of the state we then had control 
of". 43 In early November, Lincoln wrote Banks, expressing his strong disappointment that "nothing has yet been done," and urging him to work closely with Durant and Shepley. Banks was to lose no time, and "without waiting for more territory to go to work and give me a tangible nucleus, which the remainder of the state may rally around as fast as it can, and which I can at once recognize and sustain as the true state government". 44 Flanders returned in late November, bringing the President's expressed desire for speedy reorganization. This message had an immediate and tangible effect on the Free State Association. The General Executive Committee met on November 25, 1863, and selected January 25,1864 , as the most appropriate date for holding an election for a constitutional convention. It agreed to ask General Shepley to set the date. 45 Assuming that at least "an entire delegation from New Orleans in favor of abolition of slavery" could be elected, Durant thereafter pushed forward registration in the county parishes where such elections could be held. ${ }^{46}$ By December 1863, the Free State members "were at work, full of courage and hope." 47 There were registrars acting in the fourteen parishes under Union authority, and 4200 voters had already registered. 48

Amidst the new political enthusiasm accompanying the decision to hold an early constitutional convention, Durant raised for the first time the question of Negro suffrage. On December 3, 1863, in an address to the Workingmen's National Union League, he argued that the slavery issue was responsible for the war, that the South by beginning the war had stirred up revolutionary forces, and that "revolutions never leave nations as they find them." What Durant meant became more obvious when he then assured his audience that he had become a radical abolitionist 
and that he believed that blacks "who had been born free" were "equally entitled, with any other class, to all the rights, civil, education, political, and religious of American citizens." 49 At a Free State party convention, held on December 15, 1863, to elect a delegation to the Friends of Freedom convention to meet at Louisville, Kentucky, on January 8, 1864, Durant again advocated suffrage for free blacks and succeeded, in spite of strong opposition, in having two free black delegations seated in the convention. 50 On December 19, Durant addressed a meeting of the Free State Association and argued once again that suffrage for Negro men of property and education was the way to ensure freedom for the slaves and permanent peace and tranquility for the state. ${ }^{51}$ In spite of his open support of Negro suffrage, and even through he was advocating a measure far more radical than anything contemplated in the North, Durant did not lose the confidence of the Free State Association.

Durant's support of suffrage for blacks born free originated from the realization that the free black population represented an important loyal element that could give a part of the popular support the convention project needed. The movement to reorganize the state by the means of a constitutional convention furnished the free black population their first chance to press the question of suffrage. Moreover, the free blacks now had L'Union, a paper to advocate and defend their rights. Established in 1862, L'Union was printed in French and represented only the elite of the free black population of creole descent. Still it pressed firmly but respectfully for the rights of that population. In April 1863, L'Union asserted that simple justice demanded that the free colored population whose wealth contributed so largely to the support of 
the city and state governments and whose sons and husbands now served in the army should enjoy the same rights and privileges as all other citizens. $^{52}$ And on June 30 the free blacks held a public meeting at Economy Hall to impress upon the Free State people the importance of their demands. 53

A second mass meeting was held at Economy Hall on November 5, 1863, following a call of the Union Association of Free Blacks. Again the right of suffrage was the main subject of discussion. While Josiah Fisk and Dr. A.P. Dostie, two white orators who addressed the meeting, asked the free black population not to press the question of suffrage too far, three black speakers, Francois Boisdore, Capt. P.B.S. Pinchback, and C.C. Morgan, made it plain that if the blacks were not yet asking for social equality, they did expect and demand their political rights. If they were considered citizens when it comes to military duty, they should also be considered citizens at election time. The meeting concluded with adoption of a set of resolutions urging voting rights for blacks born free before the war. It also resolved that the free Negro population should petition General G.F. Shepley, the military governor, to allow the registration of free blacks. 54 By December 1, 1863, when another mass meeting was held, a petition signed by 700 people, mostly small merchants, artisans, and skilled workers, had been presented to the governor. In it the free blacks emphasized the fact that "they don't ask a favor, but a right: a right to vote as all citizens." 55 The free black leaders made it clear that they intended to have a say in the reconstruction of the state. And it seemed by late 1863 that Louisiana would not be reorganized without their participation, for the radical 
leader of the Free State Association, Thomas J. Durant, had become an open advocate of suffrage for the free black population. 56

Meanwhile, General Banks, who was maintaining a regular correspondence with the President, saw the situation differently. Determined to play an active role in the reorganization of the state, Banks shrewdly used Lincoln's letter of November 5, in which the President had blamed him indirectly for the slow reorganization of the state. 57 Banks replied to the President, on December 6, that he had always "regarded reorganization of Government here as of the highest importance" and that he had "never failed to advocate everywhere the earliest development of this interest." Then he insinuated that Durant and Shepley had rejected his collaboration and that he could not therefore be blamed for the lack of progress. Banks assured the President that if the work of reorganization in Louisiana had been "committed to me under general instructions only, it would have been completed before this day. It can be effected now in sixty days--let me say even in thirty days if necessary, with less public excitement than would attend the enactment of a 'dog law' in one of the stem States." On December 16, Banks wrote again to Lincoln, complaining about obstruction by military subalterns, court officers, and Treasury officials, and emphasizing the fact that he had only partial command in Louisiana. 58

At this time, Lincoln was also in frequent contact with Dr. Cottman and $\mathrm{Dr}$. Riddell, conservative pretenders to a congressional seat and to the governorship respectively. They were then in Washington telling the President "that the citizens of Louisiana will accept the proclamation of emancipation, provided they could come back to civil government under 
their constitution and laws." But if such illegal voters as Negroes, members of the United States Army and Navy, and residents of less than a year were admitted to the polls, as Shepley and Durant proposed, Riddell assured the President that "the mass of loyal citizens throughout the State. . would not" voluntarily concur. ${ }^{59}$ Learning from the conservatives that Louisiana was ready to accept emancipation and restoration under certain conditions, and assured by Banks that he could accomplish it in sixty days, Lincoln moved quickly. Riddell wrote to Banks on December 23, that the President had decided to place all power in Banks' hands: "he said to me that he would soon write you a letter, to take full, entire, and exclusive charge of all these matters."60 The following day, December 24, Lincoln appointed Banks "master" of the situation in Louisiana: "I now distinctly tell you that you are master of all, and that I wish you to take the case as you find it, and give us a free state re-organization of Louisiana in the shortest possible time." ${ }^{61}$.

To be fully understood the Lincoln's "Master" letter to Banks must be put in the context of the proclamation of amnesty and reconstruction of December 8, 1863, which embodied the President's plan of reconstruction. Although he excluded from his proclamation of amnesty the highranking civil and military Confederate officers, Lincoln's remaining conditions were mild. He asked only an oath of loyalty and the acceptance of the Emancipation Proclamation. Moreover, he declared that reconstruction could begin when those taking the oath equalled in numbers one-tenth the vote cast at the presidential election of 1860 . This meant that in Louisiana, which cast 50,000 votes in 1860 , as few as 5000 persons could establish a restored government. The growing split 
between the President and Congress on the question of reconstruction was a matter of grave concern to Lincoln. Reconstruction was, after all, the overriding issue of the war; the terms upon which the South was returned to the Union would affect not only the kind of nation that emerged from the war, but the very fate of the Republican party itself. Furthermore, control of reconstruction carried with it control of the party, and Lincoln had no intention of surrendering his leadership of the party to Congress. Circumstances seemed to favor making Louisiana the trail blazer for Lincoln's policy. It also involved a test of strength between the President and Secretary of the Treasury Salmon P. Chase. Lincoln knew of Chase's presidential aspirations, his influence with congressional radicals, and the role of the Chase Treasury's agents in Louisiana. Therefore, Lincoln believed that, in supporting Banks and the moderate Hahn, he could get a quick restoration of Louisiana before Congress acted and imposed its own conditions, while gaining the support of Louisiana delegates at the Republican convention of 1864 . These were some of the considerations that brought Lincoln to write his "Master" letter to Banks and put in his hands the responsibility of restoring Louisiana. 62

On January 11, 1864, after he received Lincoln's letter, General Banks issued a proclamation ordering an election to be held on February 22 , to fill the seven state offices of governor, lieutenant-governor, secretary of state, treasurer, attorney general, superintendent of public instruction, and auditor of public accounts. In the same proclamation, the general announced that "the fundamental law of the State is martial law," but he also recognized the validity of the 1852 consti- 
tution, except for the article related to slavery. Banks claimed that the main difference between his plan and the one proposed by the radicals was one of timing, yet the date he set for a state election was a month later than the one chosen for a state convention by the Free State Association. And the date Banks proposed for the election of a constitutional convention was two months later than the one suggested by the Union Association. 63 In fact, the difference was much more important than mere timing. With his proclamation, Banks had seized direction of political affairs in Louisiana and proceeded to reorganize Louisiana under the strict control of the military authorities. The plan of Banks differed from the one of Durant, who wanted a civil reconstruction which would have put Louisiana in the same condition as the Northern States. Meanwhile, Banks decided to use all his power, patronage, and influence to assure the election of his close friend, Michael Hahn, as governor. Banks expected some resistance from the conservatives and from a part of the Free State Association, which was more radical, but he calculated that such opposition, rather than posing a real threat to the election of Hahn, would simply increase the level of participation. Moreover, Banks believed that the opposition would soon disappear, and that he would be able "to harmonize all interests and to have all classes justly represented." 64 Banks intended to rally the different radical and conservative factions around his moderate candidate for governor by promising both the radical Durant and the conservative A. J. Rozier seats in the United States Senate. ${ }^{65}$ But the bitter and irrevocable opposition of both radicals and conservatives thwarted his plan.

The confusion and resentment created among the Free State members by the President's decision and General Banks' proclamation appeared in a 
series of letters sent to Lincoln and Chase, mainly by Flanders and Durant. On January 10, 1864, Flanders told Chase: "You may imagine, I shall not attempt to describe the feelings of those who have labored incessantly for months in developing and organizing the Union sentiment, for a free state Government, at this turn of affairs. On January 16, Durant's bitterness surfaced when he wrote to Chase: "It would have been better for this Major General Commanding here to have been kept out of the spheres of civil politics which must necessarily have a bad effect upon him." 66

Durant and Flanders developed a new strategy to cope with the changed situation. In a series of resolutions passed at a meeting of the General Executive Committee of the Free State Association on January 13 , the radicals decided to participate in the election, while refusing to endorse Banks' plan. They resolved to call a party convention for February 1 , in order to choose the candidates of the Free State Association for the state election of February 22.67 On the same day, Durant resigned from his two offices of Attorney General and General Registrar of Voters for the state so that he might attack Banks' policy without being accused of disloyalty. ${ }^{68}$ His resignation was the signal that any alliance with General Banks was out of the question, and that, as Flanders put it, the radicals had no "faith whatever in him and cannot have." 69 But they had not yet abandoned the idea of trying to persuade the general to change his decision about the state election. On January 15, the General Executive Committee held a second meeting and voted unanimously to present Banks with a memorial signed by all the members requesting him "to order an election of a convention on the 22nd of February, the same day appointed by him for election of State officers." 70 
Just as the radical leaders had anticipated, Banks replied to the committee that he had no objection to the time suggested by them, but that "a more careful consideration of the subject, satisfied me that there was not time to make the proper arrangements." 71

Governor Shepley's failure to reply to the ${ }_{n}^{b}$ petitioners coupled with the sudden news that President Lincoln had made Genral Banks "master" of the whole process of restoration in Louisiana led the free black leaders to change their strategy in early January 1864. In three successive meetings held on January 5, January 19, and February 8, 1864, the free blacks resolved to appeal directly to the Lincoln administration by sending a delegation to Washington. Captain Arnold Bertonneau, a wine merchant, and Jean Baptiste Roudanez, an engineer, were to present a copy of the petition which had been submitted to General Shepley, to the President and the Congress. At the mass meeting of February 8, 1864, James McKaye, who had been sent by President Lincoln to investigate the condition of the black population in the Mississippi Valley, warmly endorsed the idea of sending a delegation to Washington. 72

While the two delegates whe preparing for their journey to Washington, thirty-three black officers serving in the Union army at Port Hudson petitioned Congress to grant the black men "all civil and political rights now enjoyed by white men." 73 Additional support came from Thomas J. Durant who furnished Bertonneau and Roudanez with a letter of introduction to President Lincoln and members of Congress, asking them to receive the delegation and to extend equal suffrage to the free Negro population of Louisiana. 74 
In the meantime, the Free State Party was to convene on February 1 to choose its candidates for the coming state election. On January 31, the friends of Michael Hahn claimed the nomination for him. They assumed that he would run with or without the party's endorsement; if he did not have the Free State nomination, he would run on a conservative platform. ${ }^{75}$ Still, Hahn felt that Free State backing would give "a note of legitimacy which his candidacy needed very much, "76 and following Banks' example, he was ready to use any political trick or machination to get it. When the convention met and the committee in credentials appointed by the chairman, W. R. Crane, refused to seat some fifteen delegates for not having been regularly registered, Hahn's supporters broke up the convention by creating a terrific uproar. As the New Orleans Times reported, "several attempts were made to call the roll, and a scene of confusion was presented seldom seen in deliberate bodies. All attempts at keeping order proved futile." 77 The chairman was unable to subdue the demonstrations and ruled that the convention would move into another room. When Crane left his chair, followed by Durant and the radicals, the Hahn supporters got control of the hall. They chose a new president, W. H. Hire, and a new credentials committee, which agreed to seat the fifteen delegates whose admission had been previously contested. ${ }^{78}$ Then they unanimously nominated their candidate. To legitimize their position, Hahn's supporters argued that the radicals had "bolted" the convention. 79 Meanwhile, the radicals had proceeded to nominate another slate of candidates headed by B. F. Flanders. 80

Despite the grave schism within the Free State party, Durant and Flanders were still willing to forget the past in order to reach a 
compromise. On February 13, the General Executive Committee passed a resolution instructing Durant, its president, to confer with the president of the Hahn group, A. C. Hills. The committee hoped that differences could be resolved and a common ticket agreed upon. 81 However, the Hahn forces, assured of the victory, disdainfully rejected the radicals' offer. ${ }^{82}$ In fact, the division within the Free State party, which had begun as a clash of personalities, had become by mid-February an ideological conflict, making compromise impossible.

To ensure their candidate's election, the Hahn forces straddled the question of slavery during the campaign. They proclaimed that Hahn was "neither for nor against slavery," and pictured Flanders as a supporter of Negro equality. ${ }^{83}$ An angry Durant claimed that the opposing candidates appealed "to passion and prejudices to serve their ends," and specified that his own opposition to Hahn resulted not from personal animosity, but from the vagueness of Hahn's position on the "great question of slavery." Durant and Flanders charged "that Hahn was heading a reactionary movement detrimental to the public welfare, and therefore hostile to public liberty." 84 The bitterness of the electoral contest had brought Durant a step farther in the radical evolution of his political views.

Until January 1864, Durant had believed that Louisiana could be restored by means of a constitutional convention. But he had also insisted that as the rebels and their sympathizers were irreconcilable, a free state government must be organized slowly and carefully by the true, loyal element. To effect this, he had proposed that the franchise be limited to those who had taken a test-oath. ${ }^{85}$ By December 1863 
Durant had begun to advocate the enf ranchisement of the free-born blacks for reasons of justice and political necessity. While Durant was still working on the preliminaries of a constitutional convention, General Banks had issued his proclamation and reversed all the processes of Reconstruction in Louisiana. Assuming that slavery was the main issue of Reconstruction, Durant saw one main fallacy in Banks' plan: it committed such an "absurdity before the civilized world, as to refuse permission to the only men on whom freedom was to be conferred, to say that they were in favor of the measure." 86 Durant and the radicals knew they had lost the first round, but by linking a strong political ideology to a sense of fighting for a just and righteous cause, they found enough will and energy to continue the struggle. By then the only hope left to the radicals was that Congress would interfere with rather than recognize the Reconstruction policy of Banks and Lincoln. Durant proposed that "Congress should assume control of the whole matter and fix on an immutable basis the civil and political status of the population of African descent, before any state shall be readmitted to the Union." 87

The Conservative party, representing the old planting interest, was not indifferent to Banks' proclamation ordering a state election. But the conservatives were at first reluctant to enter the contest because of their objection to the oath required by President Lincoln in his proclamation of December $8,1863 .^{88}$ Under pressure from the conservatives, Banks wrote to the President on January 22, asking his advice on the test oath. The President replied on the 31 st that "you are at liberty to adopt any rule which shall admit to vote any unquestionable 
loyal free-state men, and none others. And yet $I$ do wish they would all take the oath." 89 Meanwhile, the rupture within the Free State party encouraged the conservatives to participate in the election, and they held a mass meeting on February 5 to ratify their platform and nominate their candidates headed by J.Q.A. Fellows. J.A. Rozier, a prominent lawyer who had voted against secession in the 1861 convention, addressed the meeting; he made it plain that although the conservatives stood by the Federal constitution, they were opposed to the new oath. ${ }^{90}$ However, by February 11, General Banks had received Lincoln's letter of January 31 , and had issued his General Order 24 , defining the qualifications of voters and requiring a test-oath for all voters. That Banks intended to limit the conservative vote by obliging everyone to take the President's oath is obvious. With his General Order 23 of February 3, Banks had already attempted to force those who had taken the oath to vote by announcing that he would consider indifference as a crime and faction as treason. 91 Denison reported to Chase on February 19, that "Fellows would probably have been elected had not General Banks issued an order requiring voters to take the proclamation oath." 92

On election day, to no one's surprise, the Hahn ticket received an overwhelming majority, with 6183 votes for Hahn, 2996 for Fellows, and 2232 for Flanders. The rest of the Hahn ticket won by similar majority. 93 Jubilantly, Banks wrote to Lincoln on February 25, that "there is no sounder basis for a State Government in this country than is presented by this population. ${ }^{94}$ Cuthbert Bullitt, a conservative friend of Hahn, wrote to Orville H. Browning, a former Whig from Illinois and old friend of Lincoln: "I gave you the glorious results of our State election. - In fact it is a triumph over Mr. Chase \& all his faction here, 
who left no stone unturned to defeat us. The truth must be told \& the sooner our worthy President knows it the better." Bullitt added, "our people are willing that the State should be free, but they cannot stand radicalism." 95 On February 23, A.C. Hills editorialized in the Era: "the people of Louisiana have spoken" and have given a glorious victory to the Hahn ticket; "the vote is an effectual answer to the charge of the bolters that they had a majority in the convention." 96

Even before the election was over, General Banks was accused of unfairly influencing the outcome by the following procedures: (1) his order of January 29, which allowed soldiers who were citizens of Louisiana to register and vote; (2) his General Order No. 23 of February 3, which required all qualified citizens to vote; (3) his General Order No. 24 of February 11, which obliged all voters to take the test-oath; (4) his appointment of Hahn supporters as election officials; and (5) his strict control of the press. If the conservatives were critical of Banks' action, their radical opponents were not idle in protesting against Banks' procedures and in pointing out the same irregularities and violations of the constitution. 97 In respect to the actual tally, the conservatives counted "4500 illegal votes cast for Hahn, the general's favorite, at the late election, \& 2000 others who were prevented from voting by his illegal \& unreasonable orders." 98 Meanwhile, Flanders explained Hahn's large majority by adding the votes of 500 city policemen to those of 1150 street laborers, to 150 city officials, to 150 state and court officals, to 850 quarter-masters and men, and to 1650 soldiers, for a grand total of 4450 votes. ${ }^{99}$ Finally, both conservatives and radicals declared not only that the election of 
February 22, 1864, was illegally conducted, but that it did not restore Louisiana to the Union. ${ }^{100}$

On March 4, "the persons claiming to be elected State officers of Louisiana were with great display inaugurated", ${ }^{101}$ while conservative unionists and Confederates offered a silent protest by forming a cortege over one mile long to pay their last respects to the wife of P.G.T. Beauregard. 102 Banks had spared nothing to present a magnificent inaugural scene: "Draped with flags and garlanded with evergreens, the platforms and the vast rows of seats beyond appeared to have sprung into existence under the touch of an enchanter's word. Unless the trees had been hung with diamonds instead of chinese lanterns, and the flags had been silk instead of ordinary bunting, there could scarcely have been nearer approach to the wild splendor depicted in Arabian tales." 103 Together the election and investiture had cost the state treasury over $\$ 10,000$; to Banks economy was unimportant when it came to recompensing Hahn's supporters and celebrating "the return of Louisiana to the Union." 104

"In Louisiana, the situation is different," Banks wrote proudly to Lincoln in March 1864; "we have changed all the elements of society--in labor, trade, social organization, in the church, and in the army. The Revolution is complete." ${ }^{105}$ Had Durant seen Banks' statement, he would have been flabbergasted. Louisiana was still under the 1852 constitution, and slavery was not yet abolished constitutionally. But though Banks proclaimed publicly that Louisiana had been restored by the election of February 22, he acknowledged privately that such was not the case. Banks not only asked President Lincoln to invest the new governor 
"with the power exercised hitherto by the military Governor," but he specified to Lincoln that "it is understood by the people that Mr. Hahn represents a popular power entirely subordinate to the armed occupation of the State." Banks added, "The election perilled nothing. Had it resulted in the election of an opponent, he would be without power. The election of a friend of the government on the other hand who acts in harmony with the military authorities, gives them the great benefit of the direct support of the people, without impairing their authority." 106 President Lincoln, by appointing Hahn military governor, concurred with Banks' views that the restoration in Louisiana was primarily a military one, in spite of the civil facade. ${ }^{107}$

While the new state government was inaugurated with pomp, the two black delegates had arrived in Washington in early March. They were well received by President Lincoln and members of Congress. The arguments of the memorial and the high character of the petitioners made a strong impression on the President. Only three days after he had met with the delegation, President Lincoln wrote to Michael Hahn, the new governor of Lousiana, to suggest that the upcoming constitutional convention should define the elective franchise in such a way as to include some of the blacks "as for instance, the very intelligent, and especially those who have fought gallantly in our ranks." Such an extension of the franchise would serve the Union cause and enlarge the political base of the Free State Party; Lincoln told Hahn, "they [The free blacks] would probably help, in some trying time to come, to keep the jewel of liberty within the family of freedom." 108 Lincoln showed some readiness to support partial suffrage behind the scenes, but he was not yet prepared 
to do it openly. Lincoln left Governor Hahn the initiative to deal as he saw fit on the suffrage question. Whether or not Governor Hahn would satisfy President Lincoln's desire for limited Negro suffrage wos a question that would be answered by the 1864 convention. 
Notes for Chapter I

1 James G. Randall, Constitutional Problems Under Lincoln (Gloucester, Mass. 1963), 215-238; G.M. Capers, Occupied City, New Orleans Under the Federals, 1862-1865 ([Lexington, Ky.], 1965), 73, 87; W.M. Caskey, Secession and Restoration of Louisiana (Baton Rouge, 1938), 45-46; J.G. Taylor, Louisiana Reconstructed, 1863-1877 (Baton Rouge, 1974), 2-3.

2J.G. Randall, Constitutional Problems Under Lincoln, 215-238; G.M. Capers, Occupied City, 90; W.M. Caskey, Secession and Restoration, 55 .

3G.M. Capers, Occupied City, 65-73; W.M. Caskey, Secession and Restoration, 50-51.

${ }^{4}$ G.M. Capers, Occupied City, 91; W.M. Caskey, Secession and Restoration, 55.

5G.M. Capers, Occupied City, 79-82, 86, 93; W.M. Caskey, Secession and Restoration, 46-47; 55, 59-63; J.G. Taylor, Louisiana Reconstructed, 14 .

6G.M. Capers, Occupied City, 91; W.M. Caskey, Secession and Restoration, 56 .

7G.M. Capers, Occupied City, 94-97; W.M. Caskey, Secession and Restoration, 57 .

${ }^{8}$ When Butler captured the city, New Orleans' population numbered 168,000 , including 14,500 slaves and 10,900 free blacks. Therefore, those 10,000 slaves represented a substantial increase in the city population. During the ante bellum period new Orleans had been an ideal refuge for slaves desiring to escape the social control of the plantation system. There slaves enjoyed a greater social and economic freedom, hiring themselves out on a rental basis in large numbers or working for free blacks. See G.M. Capers, Occupied City, 95; W.M. Caskey, Secession and Restoration, 53; W.F. Messner, "Black Violence, and White Response, Louisiana, 1862," Journal of Southern History, XLI (1975) 25; J.W. Blassingame, Black New Orleans, 1860-1860 (Chicago, 1973), 29-30; C.B. Rousseve, The Negro in Louisiana (New Orleans, 1937), 93; R.C. Wade, Slavery in the Cities, 214-225; Louis S. Gerteis, From Contraband to Freedman, Federal Policy toward Southern Blacks, 1861-1865 (Westport, Ct.,1973) argued convincingly that General Butler did not come to Louisiana to free the slaves.

${ }^{9}$ Denison to Chase, August 11, 1862, Chase Papers, LC; New Orleans Bee, September 23, October 3, November 7, 1862; New Orleans 
Picayune, July 22, August 14, September 24, 1862; New York Times, August 1, 26, 1862; W.F. Messner, "Black Violence and White Response," 19-22; P. Ripley, Slaves and Freedmen in Civil War Louisiana, 28,395. G.M. Capers, Occupied City, 97 ; W.M. Caskey, Secession and Restoration, 54 , 249; J.W. Blassingame, Black New Orleans, 25-30; C.P. Ripley, Slaves and Freedman in Civil War Louisiana, 39.

${ }^{10}$ Reverdy Johnson reported to Lincoln in July 1862 that at least 30,000 more troops were needed in Louisiana (Johnson to Lincoln, July 1862, Lincoln Papers, LC) C.P. Ripley, Slaves and Freedmen in Civil War Louisiana, 106. L.S. Gerteis, From Contraband to Freedman, 68-71.

${ }^{11}$ Lincoln, in a letter to Cuthbert Bullitt on July 28, 1862, referred to a letter by Durant protesting to Butler about the violation of the Federal pledge to protect the slave property of the loyal members of the community. Joseph G. Tregle, "Thomas J. Durant: Unionism as the Heir of Utopian Socialism", Paper presented at the meeting of the Louisiana Historical Association on March 9, 1978, 16, argued that Durant, in spite of his antislavery views, took that stand because he feared an open policy of abolition by "the occupation forces would destroy all hope of sustaining the Unionist sentiment in the state." But the view of Dr. Tregle did not seem to fit the facts, since Durant freed his slaves only in March 1863, after Lincoln had issued his Emancipation Proclamation. Lincoln to Bullit, July 28, 1865, Lincoln Papers, LC; this letter is also in Butler Papers, LC, New Orleans Bee, March 9, 1863.

12 In 1862, George S. Denison was the acting collector of the Port of New Orleans. He had lived in Texas from 1853 to 1861, when he escaped for the North. In 1862 when New Orleans fell, Secretary Chase, to whom he was closely related in politics, sent him to New Orleans.

13Jacob Barker was a young conservative banker who had remained loyal to the Union through all secessionist crisis.

${ }^{14}$ Reverdy Johnson was a northern Democrat, and friend of Lincoln, who visited New Orleans during the summer of 1862.

15Dension wrote to Chase in May 1862 that "abolition of slavery in Gulf area will create a unanimity that does not exist there. . . they all abhor the idea of the negroes being set free among them and made their equals." Denison to Chase, May 1862, Chase Papers, LC; Barker reported to Lincoln that "if the agitation about slavery is not silenced - . We are in imminent danger of another revolution a thousand times more bloody that the present." Barker to Lincoln, July 15, 1862, Lincoln Papers, LC; Reverdy Johnson notified Lincoln that an impression was growing up here "that it is the purpose of the Government to force the Emancipation of the slaves. - . . Depend upon it, my dear sir, that unless this is at once corrected, this State cannot be, for years, if ever, re-instated in the Union." Johnson to Lincoln, July 1862, Lincoln Papers, LC.

${ }^{16}$ The treatment of runaway slaves also caused controversy between General Btitier and General Phelps during the summer of 1862 . General 
Butler, who had accorded military protection to a large number of contrabands when he was commanding officer at Fortress Monroe, Virginia, adopted a more conservative stand in Louisiana. But General Phelps began to admit and protect contrabands inside Union lines, furnishing them with employment and going so far as to incorporate them in semimilitary organization. General Phelps' policies produced great concern among the planters and the white population. General Butler finally obtained the removal of General Phelps, only to adopt immediately thereafter the same policy. See Denison to Chase, May 1862, Chase Papers, LC: Barker to Lincoln, July 15, 1862, Johnson to Lincoln, July 1862, Lincoln Papers, LC; Butler to Stanton, July 8 and August 2, 1862, Letters received, RG 393, Gulf Department, War Department; See also G.M. Capers, Occupied City, 95; L.S. Gerteis, From Contraband to Freedman, 68-72; W.F. Messner "Black Violence, and White Response," 26; C.P. Ripley, Slaves and Freedmen in Civil War Louisiana, (Baton Rouge, 1976) 29-32, 104 .

17James G. Randall, Constitutional Problems under Lincoln, 342-370.

18 Among the portion of Louisiana excepted by the Presidential proclamation were 13 parishes of the state including New Orleans, St-Bernard, Plaquemines, Jefferson, St-John, St-Charles, St-James, Ascension, Assumption, Terrebonne, St-Mary, and St-Martin.

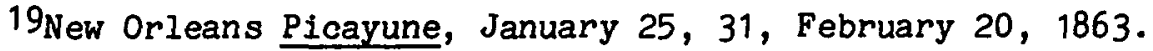

${ }^{20}$ G.M. Capers, Occupied City, 91-92; W.M. Caskey, Secession and Restoration, 57, 63-65; J.G. Taylor, Louisiana Reconstructed, 15.

21G.M. Capers, Occupied City, 91-92; W.M. Caskey, Secession and Restoration, 63-65; J.G. Taylor, Louisiana Reconstructed, 16.

22W.M. Caskey, Secession and Restoration, 70-75; J.G. Taylor, Louisiana Reconstructed, 18-21.

23Ibid., 17; New Orleans True Delta, November 16, 1862.

24 Joseph G. Tregle, "Thomas J. Durant," 17.

25New Orleans Era, March 1, 1863, cited in James P. McCrary, "Moderation in a Revolutionary World: Lincoln Policy in Louisiana", Ph.D. Dissertation, Princeton, 1972, 81-83. It is important to note here that Durant, although he had been one of the leading opponents of the secession movement and a disciple of Charles Fourier, had been himself a slaveholder up to March 1863. In early March 1863, he emancipated his slaves in court; it was at the same period that he began to play a major political role and to express radical views on Reconstruction. For emancipation of Durant's slaves, see New Orleans Bee, March $11,1863$.

26 Petition of C.W. Hornor, W.W. Handling, J.A. Rozier, T.J. Earhart for the Organization of a State Convention to General Shepley, March 7, 1863, George F. Shepley Papers, Maine Historical Society; See also New 
Orleans Bee, March 9, 1863, New Orleans Picayune, March 8, 15, 1863, and New York Tribune, March 24, 1863; L'Union, April 14, 1863.

27Minute Book, General Committee of the Union Associations of New Orleans. May $8,15,21,1863$, New York Historical Society (NYHS); Durant to Shepley, May 8, 21, 23, 1863, George F. Shepley Papers, Maine Historical Society (MHS).

28 Minute Book, May 15, 21, 1863, NYHS; Durant to Shepley, May 21, 23, 1863, Shepley Papers, MHS.

29 Minute Book, May 21, 1863; NYHS; Durant to Shepley, May 21, 23, 1863, Shepley Papers, MHS.

30Durant to Shepley, May 21, 23, 1863, Shepley Papers, MHS; Hahn to Lincoln, May 9, 1863, Lincoln Papers, LC.

${ }^{31}$ Shepley to Durant, May 25, 1863, Shepley Papers, MHS.

32Hahn to Lincoln, June 6, 1863, Lincoln Papers, LC; Minute Book, June $5,12,19,1863$, page 26-27, 38, 32-47; NYHS; Durant to Shepley, June $6,12,18,1863$, Shepley Papers, MHS.

33New Orleans Picayune, February 20, 1863.

34 Fellows to Shepley, April 19, 1863, Shepley Papers, MHS.

35Minutes of Proceedings of Louisiana Planter, May 1, 1863, Lincoln Papers, LC; Malhiot, Johnson, Cottman to Lincoln, May 1, 1863, Lincoln Papers, LC.

36 Lincoln to Malniot, Johnson, Cottman, June 19, 1863, Lincoln Papers, LC; See also New Orleans Bee, June 23, 1863.

37Dunham to Shepley, July 24, 1863, Shepley Papers, MHS.

${ }^{38}$ Durant to Lincoln, October 1, 1863, Lincoln Papers, LC; Minute Book, September 5, 12, 1863, NYHS.

39'Stanton to Shepley, August 24, 1863, Shepley Papers, MHS; A copy of this letter is also in Banks Papers, LC.

40 Fellows to Lincoln, September 5, 1863, Field to Lincoln, September 20, 1863, Lincoln Papers, LC; For more details on the election controversy see Riddell to Shepley, October 30, 1863; Lacey and Ker Report, October 31, 1863; Fellows Address to the Citizens of Louisiana, October 29, 1863; All in Shepley Papers, MHS; Barker to Banks, August 3, 1863, Banks Papers, LC; New Orleans True Delta, November 1, 1863; New Orleans Times, October 29, November 7 , December 18, 20, 1863.

41 In his article, "The Etheridge Conspiracy of 1863: A Projected Conservative Coup," Journal of Southern History, XXXVL (1970), Herman Belz presents strong evidence to support the view that the clerk of the House of Representatives was willing to use his power over the roll of 
the representatives-elect as a way to seat Cottman, Field, and Barker, leaving some Republicans off the roll in order to give control of the House to the Democrats.

42Durant to Banks, October 25, 1863, Banks Papers, LC: Shepley to Banks, October 25, 1863, Banks to Shepley and Durant, October 25, 1863, Durant to Shepley, October 24, 1863, Shepley Papers, MHS; Denison to Chase, November 6, 1863, Durant to Etheridge, November 6, 1863, Durant to Chase, November 6, 1863, Chase Papers, LC.

43Lincoln to Flanders, November 9, 1863, cited in James P. McCrary, "Moderation in a Revolutionary World", 162.

${ }^{44}$ Lincoln to Banks, November 5, 1863, Banks Papers, LC.

45Flanders to Lincoln, December 11, 1863, Lincoln Papers, LC. (Same letter in Flanders Papers, Louisiana State University Archives, Baton Rouge); Durant to Chase, December 4, 1863, Denison to Chase, December 4, 1863, Hutchins to Chase, December 10, 1863, Chase Papers, LC.

46 Durant to Chase, December 4, 1863, Flanders to Chase, December 4, 1863, Chase Papers, LC; Durant to McPherson, December 7, 1863, Durant miscellaneous, Louisiana Historical Society Library, New Orleans.

47Flanders to Chase, December 12, 1863, Chase Papers, LC.

${ }^{48}$ Shepley to Stanton, December 31, 1863, Lincoln Papers, LC.

49 New Orleans Times, December 4, 1863; New York Times, December $21,1863$.

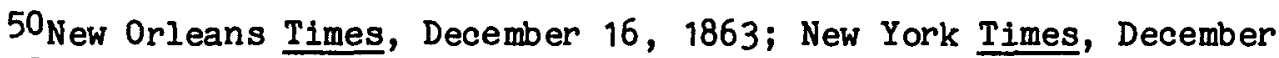
$27,28,31,1863$; See Also James P. McCrary, "Moderation in a Revolutionary World", 201-204.

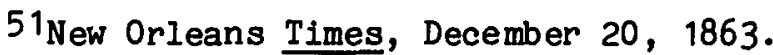

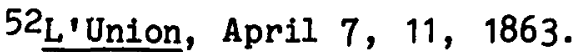

53L'Union, June 4, 30, 1863.

${ }^{54}$ New Orleans Times, November 6, 1863; W.E.B DuBois, Black Reconstruction (New York, 1935), 155-7; D.E. Everett, "Demands of New Orleans Free colored Population for Political Equality, 1862-1865," Louisiana Historical Quarterly, XXXVIII, (April 1945) 45-46; C.P. Ripley, Slaves and Freedmen in Civil War Louisiana, 164.

55L'Union, December 3, 1863.

56 Durant to Chase, December 4, 1863, Chase Papers, LC; New Orleans Times, December 16, 20, 22, 1863; New York Times, December 27, 28, 31, 1863.

57Lincoln to Banks, November 5, 1863, Lincoln Papers, LC. 
58 Banks to Lincoln, December 6, 1863, Lincoln Papers, LC (those two letters are also in Banks Papers, LC). The motives of General Banks are not difficult to understand. First Banks wanted to play an active role in the political reorganization of Louisiana so as to enhance his chance to become a dark horse candidate for the presidency if the Republican convention came to a deadlock; a second motive, which could be related to the first, was that Banks favored a more moderate policy than the radical leaders as a way to unite the loyal elements. "But if the policy proposed be too conservative or too radical it will bring on counter-revolution which will be the seeds of infinite revolution and anarchy" he wrote Lincoln on December 30, 1863. By the end of December 1863, even before he had received the presidential letter that gave him full authority, Banks had already decided upon a plan of Reconstruction that reversed the one proposed by Durant and the Free State Association. See Banks to Lincoln, December 6, 16, 30, 1863, Lincoln Papers, LC.

59Riddell to Banks, December 15, 23, 1863, Banks Papers, LC.

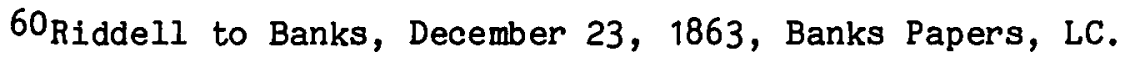

${ }^{61}$ Lincoln did not, as the conservatives wanted, give any directive on the way to proceed. See Lincoln to Banks, December 24, 1863, Lincoln Papers, LC.

62 W.M. Caskey, Secession and Restoration, 92-95; W.B. Hellestine, Lincoln's Plan of Reconstruction (Tuscaloosa, 1960) 70-72; J.G. Taylor, Louisiana Reconstructed, 23-24.

63Banks to Lincoln, January 11, 1864, Lincoln Papers, LC; New Orleans Bee, New Orleans Picayune, New Orleans Times, January 13, 1864.

64 Banks to Lincoln, January 11, 1864, Lincoln Papers, LC.

65Denison to Chase, January 29, 1863(4), Chase Papers, LC.

66 Flanders to Chase, (January 10, 1864), Chase Papers, Pennsylvania Historical Society (PHS). Durant to Chase, January 16, Chase Papers, LC; See also, Durant to Chase, February 21, 1864, Morse to Chase, February 12, 1864, Chase Papers, LC; But as Flanders wrote to Chase on January 23, 1864, those feelings could not be expressed publicly: "The feeling among the old union men against Gen. Banks for the course he has taken is getting to be intense, but it has no public expression, not aword disrespectful to the General has ever dropt from any speaker at our meeting; nor will he be treated otherwise at least before the election." Flanders to Chase, January 23, 1864, Chase Papers, PHS.

67Flanders to Chase, January 14, 1864, Chase Papers, PHS; L'Union, January $16,1864$.

68 Durant to Shepley, January 13, 1864, Durant Papers, New York Historical Society (NYHS).

69Flanders to Chase, January 14, 1864, Chase Papers, PHS. 
70 Flanders to Lincoln, January 16, 1864, Lincoln Papers, LC; Memorial to Banks, January 25, 1864, Waples to Banks, January 19(29), 1864, Banks Papers, LC; Durant to Davis, March 31, 1864, Durant Papers, NYHS; New Orleans Times, May 3, 1864.

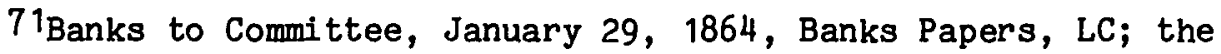
objections advanced by General Banks had no basis, since he had already been forced to resolve those questions for the state officers election and because the General Executive Committee in its preliminary work for a constitutional convention had already presented a plan of action and a way to resolve those questions.

72Memorial to President Lincoln, March 5, 1864, Petition of Free Blacks to President Lincoln and Congress, January 5, 1864; Both in Legislative Document, National Archives; S.F. Cassanave to Banks, January 11, 1864; L'Union, January 23, February 11, 1864; New Orleans Times, January 6, February 9, 1864; Petition of November 6, 1863, Shepley Papers, MHS; see also D.E. Everett, "Demands of the Free colored population of New Orleans," 50; C.P. Ripley, Slaves and Freedmen in Civil War Louisiana, 164.

73Petition of Colored Officers, Port Hudson, February 22, 1864, Legislative Document, National Archives.

74 Durant to Lincoln, February 10, 1864, Lincoln Papers, LC.

75Denison to Chase, January 29, 1863(4), Chase Papers, LC. New Orleans Times, February 1, 1864.

76 James Peyton McCrary, "Moderation in a Revolutionary World", 237.

77In his testimony before the Smith-Brady Commission, investigating corruption in the Gulf Department, W.R. Crane gave a clear description of the scene that occurred at the Liberty Hall and how by disturbance and police interference, the Hahn group got control of the hall (National Archives, War Department, RG 94, Smith-Brady Report, Box 7, Crane testimony, May 2, 1865.) See also Durant to Davis, March 31, 1864, Durant Papers, NYHS; New Orleans Times, February 1, 3, 1864.

${ }^{78}$ Hahn could not have received the nomination of the Free state party without disrupting the convention. His delegates, plus the 15 whose admission was contested, made only 51, while the total number of regular delegates was 81 . Taking the 15 from 51 , the number left would be but 36 , while a majority was no less than 41" (New Orleans Times, February 3, 1864). J.M. Wells for 1t-governor, A.S. Wrotnowski for secretary of state, J.G. Belden for treasury, B.F. Lynch for attorney general, A.P. Dostie for auditor of public accounts, and John McNair for superintendent of public education were the other candidates nominated by the Hahn forces. See New Orleans Times, February 2, 1864.

79 New Orleans Era, February 16, 1864. F.H. Harrington, Fighting Politician; Major General N.P. Banks (Westport Ct., 1948) 145, erron- 
eously held the view that the radicals left because the moderates had a majority in the convention, while W.M. Caskey, Secession and Restoration, 97-98, rightly pointed out the irregular procedures of the Hahn group and assumed that the charges of the radicals were well founded.

${ }^{80}$ Since Durant had already decided that he was not going to be a candidate, he wrote to the convention on February 1, "Having been prevented by superior force from completing, with the aid of the known Friends of Freedom in Louisiana, the plan for the reorganizaton of civil government, which had been prepared and was being successfully carried on by the Free State Committee, it seemed to me inconsistent with my self-respect, as thoroughly identified with that plan, to consent to be a candidate under the scheme that destroyed it; and this determination I beg leave to announce to my friends in your Convention" (New Orleans Times, February 3, 1864). The radicals proceeded, after a warm debate, to nominate as their candidate for governor, B.F. Flanders, for Itgovernor, J.M. Wells, for secretary of state, J.C. White, for Treasurer, A. Shelly, for attorney general, C.W. Hornor, for auditor of public accounts, W.M. Abbott, and for superintendent of public education, B.L. Brown.

${ }^{81}$ Dension to Chase, February 5, 19, 1864, Chase Papers, LC; Durant to Hills, February 13, 1864, Durant Papers, NYHS; New Orleans Times, February 14, 17, 1864.

82 New Orleans Era, February 16, 17, 1864; see also James P. McCrary, "Moderation in a Revolutionary World", 243.

83Denison to Chase, February 19, 1864, Durant to Chase, February 21, 1864, Hutchins to Chase, February 24, 1864, Chase Papers, LC; L'Union, February 11, 1864; New Orleans Era, February 9, 13 16, 18, 1864; New Orleans Times, February 1, 14, 1864. See also W.M. Caskey, Secession and Restoration, 104, and Joe Gray Taylor, Louisiana Reconstructed, 1863-1877, (Baton Rouge, 1974), 29.

${ }^{84}$ Durant to Chase, February 21, 1864, Chase Papers, LC; Durant to Boutwell, February 25, 1846. Durant Papers, NYHS; New Orleans Times, February 6, 14, 1864. Durant acknowledged in his letter to Chase that he thought Hahn only a subordinate agent of a military authority who used influence and tricks to promote his success.

85 The test-oath proposed by Durant was merely an oath of allegiance and was not related to the oath asked by President Lincoln in his Proclamation of December 8, 1863.

86 Durant to Chase, February 21, 1864, Chase Papers, LC.

87Durant to Chase, February 21, 1864, Chase Papers, LC.

88 Roselius to Lincoln, January 12, 1864, and Barker to Lincoln, January 22, 1864, Lincoln Papers, LC; See also New Orleans Era, February 17,1864 .

${ }^{89}$ Lincoln to Banks, January 31, 1864, Lincoln Papers, LC. 
90 Denison to Chase, February 19, 1864, Chase Papers, LC; New Orleans Times, New Orleans Picayune, February 6, 1864. When Roselius declined to become the conservative gubernatorial candidate, the conservatives chose Fellows to head their ticket, followed by J.M. Pelton for It-governor, G.S. Lacey for secretary of state, John Gauche for treasurer, J.A. Rozier for attorney general, Julian Neville for auditor, and Dennis Cronan for superintendent of public education. See W. M. Caskey, Secession and Restoration, 102-106.

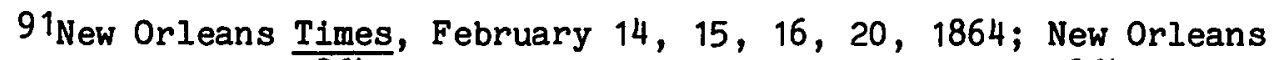
Era, February 17, 1864; New Orleans Times, February 17, 1864; General Order No. 23, February 3, 1864, Scrapbook of Orders received and sent, Gulf Department, War Department, National Archives; See also James P. McCrary, "Moderation in a Revolutionary World", 266.

92Denison to Chase, February 19, 1864, Chase Papers, LC.

93Hahn to Lincoln, November 23, 1864, Lincoln Papers, LC; See report on election return, February 23, 1864, Banks Papers, LC.

94Banks to Lincoln, February 25, 1864, Lincoln Papers, LC.

95Bullitt to Browning, February 23, 1864, Lincoln Papers, LC.

96 New Orleans Era, February 23, 24, 25, 26, 1864.

97 Christie to Lincoln, February 28, 1864, Lincoln Papers, LC; Flanders to Chase, February 26, 1864, Chase Papers, PHS; Durant to Chase, March 5, 1864, Chase Papers, LC; Durant to George Boutwell, February 25, 1864, Durant to Lincoin, February 26, 28, 1864 (those two letters are also in Lincoln Papers, LC), Durant to Stevens, February 29, 1864, Durant to Davis, March 31, 1864, Durant Papers, NYHS; See also a letter of Durant to Davis, July 26, 1864, published in the New Orleans Times, New Orleans Picayune, New Orleans True Delta, and New Orleans Era, August 18, 19, 20, 1864; See another letter of Durant to Davis, October 27, 1864, Library of Congress; Finally, "A Memorial of T.J. Durant and Others to Congress", December 7, 1864, published in Senate Mis. Doc. No. 2, 2nd session, 38th Congress.

98Fellows to Collamer, March 4, 1864, Lincoln Papers, LC.

99Flanders to Chase, February 26, 1864, Chase Papers, PHS; Durant in his letter to Boutwell on February 26, 1864, reported a similar number of illegal votes (see Durant Papers, NYHS). In his testimony before the Judiciary Committee of the United States Senate, Banks denied the charges that the election of February 22, 1864, had not been conducted according to the constitution and laws of Louisiana: "In this election no person voted who was not by the constitution and laws of Louisiana a voter, except one class of persons. These were the soldiers who, as citizens of Louisiana, had enlisted in the armies of the United States." Banks boldly assumed that although 10,000 citizens of Loulsiana were enlisted, only 808 soldiers and sailors voted and that "I do not believe that 500 persons voted in this election of the 22 of February who were not citizens of the State previous to the rebellion." 
Banks concluded his testimony by rejecting as irrelevant any criticism made against his actions, since "departure from the Statute provisions of the State rests upon the impossibility of an exact compliance therewith." See Senate Mis. Doc. No. 9, 2nd session, 38 th Congress; see also for more information on the defense by Banks of the validity of the February 22 election, House Report No. 13, 2nd session, 38 th Congress, and "Letter of N. P. Banks to Senator Lane" September 24, 1864, in Library of Congress. A subsequent report made by J.R. Terry, Register of Voters in the parish of New Orleans, to Governor Wells on March 6, 1865 , shows that more than half the registered voters in New Orleans were illegally registered.

100 Bacon to Lincoln, March 4(5), 1864, Fellows to Cottman, March 4, 1864, Fellows to Collamer, March 4, 1864, Lincoln Papers, LC; Durant to Chase, March 5, 1864, Chase Papers, LC.

${ }^{101}$ Bacon to Lincoln, March 5, 1864, Lincoln Papers, LC.

102New Orleans Picayune, March 4, 5, 1864.

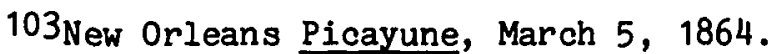

${ }^{104}$ Banks to Lincoln, March 6, 1864, Lincoln Papers, LC; a state auditing committee studied this spending after the election and made its report to the state auditor. An original copy of this report is found in Box 21, Smith-Brady Report, RG 94, War Department, National Archives, while a print copy was published in New Orleans Times of November 15, 1864. See al so W.M. Caskey, Secession and Restoration, 112-115.

105 Banks to Lincoln, March 21, 1864, Lincoln Papers, LC.

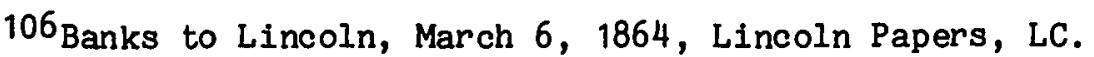

107Lincoln to Hahn, March 15, 1864, Lincoln Papers, LC.

108 Lincoln to Hahn, March 13, 1864, Lincoln Papers, LC. 


\section{CHAPTER II}

\section{Louisiana under the Hahn-Banks faction}

Although he had achieved his goal of placing his own candidate, Michael Hahn, in the gubernatorial office, Banks could not be content until he was certain that men devoted to his views would be chosen at the coming convention election. Toward this end, Banks not only postponed his departure for the Red River, ${ }^{1}$ where a major campaign was under way, but made extensive use of patronage and influence. One result was that the delegates elected to the state constitutional convention represented neither the "best class" of the Louisiana population nor the most radical group among the Union element--a circumstance that imperiled popular support of whatever constitution emerged from convention deliberations. In practical political terms, pro-constitution forces could expect opposition from both conservatives and radicals. Men with wildly divergent views could agree on the shortcomings, the wrongdoings, and even the corruption and fraud that tainted both the 1864 convention and the general civil reorganization of Louisiana. The preconditions for political chaos were clearly present. Accordingly, an understanding of the reaction of the Louisiana white population in 1866 to the reconvening of the 1864 convention requires a rather full picture not only of the real achievements of that convention, but also of the corruption, scandals, and shortcomings pervading the work of the 1864 convention and the Free State Legislature of 1864-1865. 
Thomas Durant was one of those who quickly repudiated the new regime. At first he had thought of running for election to the convention, 2 but he changed his mind after the election of February 1864. On March 5, he informed Chase of his decision and attacked Banks who, he said, had "carried his election under the oligarchic constitution, vitalized by his military edict. . ." and "is now about to declare how many members shall be elected to a constitutional convention, what should be the basis of representation. . . which simply means that he will declare who the members of the convention should be and [what] the convention shall do." 3 Durant felt that under those conditions, he could not run. On March 19, Durant nade public his decision not to be a candidate at the coming election. 4

While Durant boycotted the convention election and appealed to Congress for redress, two alternatives existed for radicals not enamoured of their leader's tactics. They could either join the Hahn faction and be elected on the moderate ticket, or they could attempt to be elected on their own. The names on the two tickets contesting the March 28 election showed that at least ten radicals who had supported Flanders in February chose to run on their own, while only two joined the Hahn ticket. ${ }^{5}$ The election produced an overwhelming victory of the moderate faction in the city of New Orleans, with 59 candidates elected. Only four anti-Hahn candidates prevailed under the Free State Citizens banner--one conservative, two moderates, and one radical. All of the prominent radicals were defeated. 6

Nevertheless, the result was clouded by a very low voter turnout, traceable to the declared boycott of the election by leading radicals 
and conservatives, coupled with cold rainy weather. The vote was so small that Hahn felt it necessary to apologize to Lincoln when he reported the election results that made Louisiana a free state. ${ }^{7}$ The victory was also not a popular one in terms of public opinion. Banks' methods had discredited the elected delegates whom a large portion of the population looked upon as representing "rowdy" and corrupt elements. ${ }^{8}$ It was therefore predictable that the work of the convention, and the constitution it produced, would suffer from the low reputation of its framers.

A thorough investigation of the social background of the 96 delegates who served in the 1864 convention, reveals their middle-class origins. The professional class contributed 33 delegates, the business community 36 , and the working class only 15 . The 1864 convention differed from the 1845,1852 , and 1861 conventions principally in the fact that the agricultural interests had only four representatives (Appendix I). Although 59 delegates held office during the war, one fact is certain, the old political elite was not represented in the 1864 convention. Only 13 of the 96 had been politically active in the 1850's and only 19 had held office prior to the war. ${ }^{9}$ A large number were appointed to public office after Hahn's election, and still more after the convention.

Moreover, a study of the wartime history of the delegates indicates that 37 of them served either in the Confederate army or in the Confederate Louisiana State militia, and that five others held public office under the Confederacy. ${ }^{10}$ Thus at least 42 delegates, or $44 \%$ of the assembly, sympathized with the Confederate cause before the fall of New 
Orleans. The federal occupation, plus a sense of prudence and a desire to hold offices ( 32 of those 42 delegates held offices as Union men during the War), might explain this shift of many delegates from the Confederate to the Union cause. They were ready to fill the vacuum left by the conservatives who could not accept the policy of General Banks on emancipation or who had left to serve in the Confederate army.

On April 6, 1864, the delegates convened at Mechanics' Institute, where they deliberated for the next 111 days. The convention quickly drew harsh criticism from the New Orleans Times, a radical paper, ${ }^{11}$ for presuming to exercise powers the Times felt more correctly resided with the people, and for spending more than $\$ 1200$ a day while deliberations proceeded without visible result. (The convention had voted each member a $\$ 10$ per diem.) The Times asserted that the constitution merely required slight revision on the question of emancipation and on the status of blacks, a task that should have required little time. Much capital was therefore made by the Times of the convention's casual pace, the drafting, the "lack of decorum," and the lavish expenditures. 12 The fairness of the criticism of the Times was even acknowledged by A.C. Hills, a Hahn supporter, who was also a member of the convention and the editor of the New Orleans Era. ${ }^{13}$

The major achievement of the new constitutional document, a revision of the old 1852 constitution, concerned the status of the black population. Slavery was abolished and the recognition of property in man forever prohibited. Also recognized were the rights of blacks to education, to equality before the law, to service in the milita, to the franchise,--though the latter was limited to an article of the constitu- 
tion which empowered any future legislature to extend the right of suffrage to citizens in considerations of military service, payment of a certain amount of tax, or intellectual fitness, without distinction of color. Another important change involved a return to a "white" basis of representation, which had the effect of substantially enlarging the importance and influence of the city of New Orleans. In the new apportionment, the city would have 44 of the state's 118 legislators, up from the 24 of 100 in the previous arrangement. Moreover, the new constitution differed greatly from the 1852 constitution by prohibiting the extension of banking and discounting privileges to corporations and by fixing the wages and hours of persons employed on public works. These changes revealed a decisive shift from the recognition of the mercantile and planting interest to a consciousness of the rights and needs of labor. In the same spirit, the convention demonstrated a preoccupation with public welfare and a desire to end the reign of police thuggery that had prevailed in New Orleans during the 1850's. The police of New Orleans were strictly regulated: they were to be overseen by a fivemember public police board; they were to be permanent citizens of the state and to wear uniforms. Finally, the new constitution denounced the rebellion, rejected the secession proclamation, repudiated Confederate debts, and reaffirmed loyalty to the United States constitution. ${ }^{14}$

In sum, the new constitution was a much more progressive document than its predecessor. Still, it had many shortcomings that reflected the majority's strong prejudice against blacks. If the majority of the conventionists was willing to accept emancipation, this liberal attitude did not extend to questions of education and suffrage for blacks. On June 17, 1864, Denison informed Chase that "prejudices against the 
colored people is [sic] exhibited continually--prejudices bitter and vulgar." He added that the whole attitude of the conventionists is "ungenerous and unjust" and that "the attempt to induce such a convention to grant to colored men limited right of suffrage, or any other right--would be futile." ${ }^{15}$ Careful study of the daily debates confirms Denison's appraisal. ${ }^{16}$ John Henderson, Jr., who was to die during the 1866 New Orleans riot, declared on the floor of the convention that he was in favor of only a white electoral basis, and that his support of emancipation did not mean that he favored a government based on racial equality. Benjamin H. Orr, another conventionist, announced that he would "vote against giving the negro the right of suffrage" and that he would "vote against it on all occasions." Other delegates who could not be classified as conservatives, such as W.T. Stocker and J.H. Wilson, told the convention either that they had "no friendship for the negro" and that they would oppose lifting of legal restrictions in a number of spheres, extending from emigration to education, or they did not believe that the African was equal, either politically or socially, to the white man. ${ }^{17}$ Alphonse Cazabat, one of the few liberals in the convention, became so upset by the prejudices of the majority that he told the convention that "the hue and cry" over Negro equality and the "declaration of future dangers" revealed "a spirit of cowardice," and he concluded by asking the delegates if they were "afraid that the despised African shall become your equal or superior?" ${ }^{18}$

It is clear from the work of scholars of wartime Louisiana, particularly that of J. Peyton McCrary, that a strong and bitter prejudice against blacks persisted within the convention. This hostility was partly overcome by the fact that the liberals, though in a distinct 
minority, ${ }^{19}$ were able to influence the work of the convention by making effective use of parliamentary maneuvers and by assuming the chairmanship of the committees handling the most controversial issue of emancipation, black suffrage, and public education. ${ }^{20}$ The influences that such men as the arch-conservative Edmund Abell were able to exert on the convention amply demonstrated the "fragile quality of its commitment to freedom" and supports McCrary's view that the convention barely managed "to stave off the white supremacy advocates through shrewd parliamentary maneuvers." 21

Parliamentary maneuvers were not required to secure the adoption of the two articles on emancipation since almost everyone acknowledged the necessity of their adoption: the only question was whether or not slave owners should be compensated. But such maneuvers played an important role in the adoption of the articles on public education, without distinction of race, and amendments allowing blacks to serve in the militia and granting them due process of law. ${ }^{22}$ McCrary credits the adoption of the clause allowing the Legislature to grant a limited suffrage to blacks and the convention's change of vote on that issue to parliamentary devices and the influence of General Banks. At one critical point, for example, the liberals seized upon the momentary absence from the floor of the arch-conservative Abell to present a "sneak" amendment that had the effect of revising a previous decision on suffrage from a vote of 74 to 14 against to a positive vote of 48 to 31.23 The convention had been under pressure by Governor Hahn to pass such an amendment. The governor's support of partial suffrage originated in a letter of President Lincoln that he had received in March 1864. The 
president had expressed to the new governor his wish that the new constitution embody an article granting partial suffrage to the black population. 24

A study of the votes cast by conventionists holding office and candidates on the Hahn ticket at the Legislative election of September 5, 1864, reveals a clear connection between those who changed their votes and those who won appointments or were selected as candidates for the Legislature. A comparison of the two wildly contrasting votes on the suffrage issue produces the following pattern: 29 twice opposed the measure, 12 supported it twice, 2 supported it the first time but were absent for the second vote, 13 opposed it at the first vote but were absent at the second vote, 2 were absent twice, 2 were absent at the first vote and opposed it at the second vote, 4 were absent the first time and supported it the second time, which left 32 who had originally voted "no" supporting the suffrage question on the second vote (See Table II.1).

Table II.1

Voting pattern on the question of black suffrage

Second Vote

\begin{tabular}{|c|c|c|c|c|}
\hline First Vote & for & against & did not vote & total \\
\hline against & 32 & 29 & 13 & 74 \\
\hline for & 12 & 0 & 2 & 14 \\
\hline did not vote & 4 & $\underline{2}$ & 2 & 8 \\
\hline total & 48 & 31 & 17 & 96 \\
\hline
\end{tabular}

Sources: Convention Journal, 74, 130. 
of these 32 delegates, 23 held office, of whom 11 were appointed after the convention adjourned. These 11 people represent more than half of all conventionists who were appointed to any office after the convention by Governor Hahn. Only two of the 29 who twice voted in opposition received any appointment to an office after the convention adjourned. 25 of the 32 delegates who changed their votes from opposition to support, 19 were candidates at the legislative election of September 5, 1864. As George Fosdick reported, Hahn rewarded some delegates who had voted favorably on the question of black suffrage by making ${ }_{n p l a c e}$ for them on his legislative ticket. 26 In summary, of the 32 who changed their vote, 11 were rewarded by a seat in the legislature, 8 by a seat and an office, and 3 by an office--a total of 22 receiving some kind of reward. Clearly Governor Hahn resorted to his patronage power to influence the convention; that pressure explains why the suffrage amendment passed so quickly, without debate.

Rumors of continued corruption with the convention served further to discredit that body in the eyes of a sullen and hostile populace, restive under continued military occupation. The possibility that the new constitution would not be ratified had become quite real. Before adjourning, the convention accordingly took the singular action of passing a motion to allow its president to call delegates together again if he thought it necessary. It was understood at the time that this expedient would be used only if the constitution was not ratified by the people. It was subsequently to be put to quite a different use. 27

During the spring and summer of 1864 , the radical New Orleans Times, and the moderate New Orleans Era had questioned the "get-rich-quick- 
fever", especially expressed in their $\$ 10$. per diem, that seemed to move many of the delegates, ${ }^{28}$ but it was only later in the year, after the constitution had been ratified, that the fraudulent financial dealings of the convention took on the dimensions of a major scandal. General S.A. Hurlbut, who had superseded General Banks temporarily as the commanding officer of the Gulf Department, became alarmed by the report of State Auditor Dostie which report revealed the exorbitant expenditures of the convention. On October 20, Hurlbut asked Governor Hahn to send him an early accounting of the amount of money that was in the state treasury when he assumed office, the amount spent since, and the amount spent for the convention. Although Governor Hahn had forwarded the letter to the state auditor, General Hurlbut, impatient to receive an answer, two days later asked the state auditor to furnish him a report on the details concerning the $\$ 156,825.20$ spent for printing and advertising, and the $\$ 46,395.25$ spent for "contingent expenses" that he had referred to in his early report. On October 31, the auditor forwarded to Governor Hahn a statement upon the balances of the general funds in the treasury from March 9 to October 27, 1864, specifying that out of $\$ 688,598.69$ on March $9,1864, \$ 541,147.22$ had been spent by October 27 , leaving only $\$ 147,451.47$ in the state treasury. Of the money spent, $\$ 392,939.92$ was for the state convention--72\% of the total for that period. The auditor reaffirmed that $\$ 46,395.25$ went for the contingent expenses of the convention, while $\$ 155,427.70$ went for the mileage and salaries of the members of the convention. Another $\$ 191,116.97$ had been paid for the printing of debates, journal, and proceedings of the convention. Moreover, the auditor added that $\$ 71,509.65$ was still left to be paid on the printing. The stupendous 
character of those amounts can perhaps best be appreciated by a comparison with the costs of similar conventions in other states. Although the state of Missouri had $\$ 2,404,639$ in her treasury, the state convention of October 1862 cost only $\$ 14,000$. In 1863, West Virginia, with $\$ 150,000$ in her treasury, spent $\$ 2,028$ for her state convention. 29 Proof that the enormous expenses in Louisiana constituted fraud remained to be advanced, but General Hurlbut's requests had the effect of opening the way for a full-scale investigation.

Late in October the radical New Orleans Times and the moderate New Orleans Era attacked the convention's financing procedures and particularly questioned the stupendous cost of the convention's printing. ${ }^{30}$ Following this outburst of the press, the state legislature formed two different committees to investigate the spending of the convention. ${ }^{31}$ It was quickly established that the True Delta, the convention's printer, defrauded the state treasury of at least $\$ 80,000$ to $\$ 85,000$. It was also discovered that Governor Hahn who had kept a share in the True Delta $^{32}$ was involved in a conflict of interest. It was futher shown that Michael De Coursey, the sergeant at arms of the convention, had defrauded the state of over $\$ 3,000$ (by submitting false vouchers). Finally, it was proven that several members of the convention, including its president, had drawn $\$ 5,380$ in per diem salaries after the convention had adjourned. 33 When these fradulent practices were combined with the prevailing desire of the conventionists to hold all the profitable offices in the city and state, it explained why they reacted with so much anger in 1865 to Governor Wells' policy of putting his own men in office. Their greed and desire for offices would bring them to the decision in the summer of 1866 to reconvene the 1864 convention. 
Meanwhile, General Banks and Governor Hahn readied plans in August 1864 to achieve the ratification of the constitution by the same methods they had used so successfully earlier in the year. Their principal hazard was the fact that a large part of the population believed, as Denison reported to Chase, that "the whole civil reorganization in Louisiana is a cheat and a swindle." ${ }^{34}$ The ratification election soon confirmed this view. In spite of the undue interference by Banks, the turnout was 30 percent lower than in the gubernatorial election of February 1864.

Before the election, Banks was supremely confident of the outcome. "The constitution is already ratified in Louisiana," he said to Dostie, "It is not in human power to defeat it here, but it may meet serious opposition elsewhere." 35 The strategy of Hahn and Banks was to enlist the support of President Lincoln, the collaboration of the press, and, finally, to suppress the radical opposition.

The first goal was easily accomplished. Hahn went to Washington to report personally to the President, while Banks wrote Lincoln that the constitution is "one of the best ever framed. The convention--reviewing the circumstances under which it has labored--is entitled to the highest respect and the warmest support of the government." Then Banks added that the constitution

abolished slavery in the State and forbids the legislature to enact any law recognizing property in man. The emancipation is instantaneous and absolute without condition or compensation and nearly unanimous. It confers upon the legislature the power to grant the right of suffrage to negroes. It provides for the compulsory enrollment of all able-bodied men in the militia without distinction of race or color. It requires the legislature to provide means for the education of all children without restriction as to color. 36 
Lincoln was persuaded and soon announced he was "anxious" that the new constitution be ratified. 37

Banks also easily acquired the support of the press. Only the New Orleans Tribune, a free black paper, openly editorialized against the constitution because "its authors were unprincipled tricksters and their work was necessarily detrimental to the public will," The New Orleans Picayune, a conservative paper, remained silent. ${ }^{38}$ Compelled by the end of the electoral campaign to support the new constitution, the New Orleans Times, overcame its early opposition: "We might, with reason, advance many objections to this constitution, but we could, with still more reason and justice, advance many arguments for its adoption. Therefore, we shall vote for it." Banks was, or course, ensured of the total collaboration of the New Orleans Era, edited by A.C. Hills, and the True Delta, edited by W.R. Fish, both members of the convention. Both the Era and the True Delta proclaimed that the ratification of the constitution would not only bring immediate admission of Louisiana to the Union, but also "open the way for all other States, following the path of the victorious Union army" to "set an example to the world--an example of democratic liberty." 39

Banks completed his pre-election planning by declaring all citizens of Louisiana enlisted in the Union army eligible to vote. He appointed J. Randall Terry as register of voters for the parish of New Orleans, and allowed him to proceed to register the voters without following the regular procedure. 40 As the election day drew near, the Banks-Hahn forces felt assured of drawing a turnout as large as the election of February 22--over 11,000 votes. On August 25, Dostie announced to Banks 
that he expected even greater participation than had been achieved the preceding February. The Era joyfully proclaimed that 13,000 people had taken the oath and were registered as voters. Finally on September 2, Alfred C. Hills wrote to Banks that "before the people in defense of this policy, you could be invincible, if we succeed in getting out 13,000 or more voters next Monday. 41 Thus, Banks was not prepared for the disagreeable surprise he received on September 5, when the constitution was ratified by only 6836 voters. Another 1566 opposed. 42

The following day, Banks had the difficult task of explaining to President Lincoln the meaning of the low turnout. Banks began his letter to Lincoln on a positive note. "I am gratified to be able to report that the constitution was ratified by a very large majority of votes, and that intelligent, able and patriotic men have been elected to Congress." He then conceded that "the vote is not so large as we expected." He offered a variety of reasons. First, "interested parties, secretly represented that all citizens registered or voting in the election would be forced into the military service of the country." "No representations could disabuse them of this fear," he added, and "many of the men employed by the Government declined to vote or to register for this reason." Banks also asserted that "the officers of the Government, civil or military, have not assisted with energy," and that "with the exception of Mr. Denison, collector, no aid has been given by the Treasury Department." Banks claimed, too, that September, "the fever month," found "many of the most prominent and influential registered voters absent in the North," and "great heat" made it difficult for "a large class of men to particpate in the contest." Finally, Banks com- 
plained of a shortage of funds to bring voters to the polls and observed that "the time allowed for the canvass was unusually short." 43

General Banks was not at the end of his troubles, as the irregularities of those elections soon surfaced under the investigations of the press, the radicals, and the Smith-Brady Commission. The Smith-Brady Commission, appointed by President Lincoln in December 1864 to investigate corruption in the administration of the Gulf Department, was the first agency to take a close look at civil affirs in Louisiana. This commission began to study the election after Durant published a letter in the New Orleans Times in the spring of 1865 specifying serious irregularities in the process of registration. Durant acknowleged that the city of New Orleans cast 5,451 votes, 4,662 in favor of and 789 against the constitution at the election of September 5, 1864, while there were 9,995 registered voters. But by sub_tracting from that total some 4,918 persons that the Registrar of Voters recognized as being imperfectly registered, Durant concluded that the ratification was a "hoax." 44 The Register of Voters in New Orleans, J.R. Terry, and his subordinates appointed by General Banks, all testified before the Smith-Brady Commission that a large number of persons were registered without being required to present papers of naturalization. They added that the original registration sheets had been destroyed when the list of voters was transcribed in new books of registration. Moreover, Terry testified that General Banks ordered him verbally to "register all persons of lawful age whether citizens of the US or not" and that he had felt obliged to comply with the order since "we are under martial law, and military order." He submitted to "the will of the commander." The Smith-Brady Commission also discovered that soldiers were forced to vote under the 
supervision of their officers, that workers were advised that they would lose their jobs if they did not vote, and that illegal polling places had been established. The greatest irregularity, however, occurred on the day of the election when at two o'clock in the afternoon Governor Hahn and Sheriff Shaw intervened directly in the election to ensure the victory of M.F. Bonzano, the chairman of the committee on emancipation in the late convention, over his conservative opponent, Edmund Abell, for the Congressional seat from New Orleans. Consequently, Bonzano was able to defeat Abell by more than one hundred votes. Angered by this interference, Abell decided to challenge the election. But Governor Hahn succeeded in convincing Abell to drop the case by promising him the important office of Judge of the First District Criminal Court of the Parish of New Orleans. 45

As if all this were not enough to cast a heavy shadow over the election proceedings in the Parish of New Orleans, it was also discovered that in many countryside parishes the votes of Union soldiers constituted the only votes cast for members of both houses of the legislature. 46 Still, the Hahn faction was not satisfied with having swept the election, it also wanted to remove all radicals from office. Angered by the opposition of Durant, who was arousing northern public opinion and Congress against the new state government of Louisiana by a series of letters, memorials and addresses to northern political meetings, the Free State leaders pressed President Lincoln to remove the officials of the Treasury Department in New Orleans because of their support for Durant and on the false grounds that they did not vote in the September 5 th election. 47 
The Free State legislature that convened on October 3 shared many characteristics with the late convention. In fact, out of 94 members of the two houses 53 of them--or 56.4\%--had served as delegates to the conventior. Only eight of the 94 state senators and representatives had been politically active before the war, while 14 of them had held some kind of office during the $1850^{\prime} \mathrm{s}$. This contrasted with the fact that 70 of them--or $74.5 \%$--did hold an office after the fall of New Orleans. 48 Moreover, 33 of them had served in the Confederate army or Confederate State militia, and four others had held office under the Confederacy, which meant that $39.4 \%$ of them had ostensibly sympathized with the Confederate cause, while only two had enlisted in the Union army. Finally, as in the convention, the members of the legislature were overwhelmingly middle-class people, coming from the business and professional community (See Table II.2).

The five-month record of the fall and winter legislature of 18641865 was thin in everything, except expenditures. More than $\$ 200,000$ was spent in the course of passing 22 minor bills. 49 Governor Hahn's performance during the session cannot be described as impressive. He had scant influence on legislation, failed in his efforts to control the legislature's choice of two United States senators, hesitated indecisively on the matter of the rights of freedmen, and generated a disruptive controversy over Supreme Court appointments. All of which served to reveal that the job was too much for him. His lack of leadership was especially conspicuous in the matter of Negro suffrage. Although he had succeeded in persuading the convention to adopt article 15, in line with the recommendation of President Lincoln, Hahn did not succeed in convincing the Legislature to grant blacks partial suffrage. 
Table II.2

Occupation of the Members of the 1864-1865 Legislature

\begin{tabular}{|c|c|c|}
\hline $\begin{array}{l}\text { Occupation } \\
\text { Professional }\end{array}$ & $\begin{array}{c}\text { Number } \\
18\end{array}$ & $\begin{array}{c}\text { Percent } \\
23.3\end{array}$ \\
\hline Low Level Prof'essional & 12 & 15.6 \\
\hline Business & 15 & $19 \cdot 5$ \\
\hline Low Level Business & 16 & 20.8 \\
\hline Skilled Worker & 10 & 13.0 \\
\hline Laborer & 6 & 7.8 \\
\hline Total & 77 & $100.0 \%$ \\
\hline
\end{tabular}

Note: Anybody who held such occupation as doctor, lawyer, minister, reporter or teacher was considered as professional, while clerk and bookkeeper were seen as Low Level professional. While bankers, merchants, accountants, and brokers were regrouped in the category of Business, small dealers, grocers, coffeehouse owners, and undertakers composed the Low Level Business group.

Sources: Debates in the House of Representatives of the State of Louisiana, Sessions 1864-65. New Orleans, 1865; Debates in the Senate of the State of Louisiana, Session 1864-(1865); New Orleans, 1865; Census Reports, New Orleans, 1860, 1870, Microfilm Room, National Archives; Gardner's New Orleans City Directory for 1861, 1865, 1866, 1867; New Orleans Picayune, September 6, 1864.

Many free blacks had considered the attitude of the 1864 convention

a setback to the movement for equal suffrage. Disappointment among them was very great. Some of them thought of testing "the rights of colored citizens of this State in regard [to] the elective franchise" before the United States Circuit Court, but finally rejected the idea on the advice of Christian Roselius, advice which was reinforced by General 
Banks' refusal to support their cause. In their disappointment many free people of color decided to emigrate to Mexico, while others followed the lead of the New Orleans Tribune in expressing open contempt for and opposition to the new state government. ${ }^{50}$ This setback also brought a radical change in the strategy of the fight for equal suffrage. Originally the free black population had demanded suffrage primarily for its prosperous, well educated members. ${ }^{51}$ The first major change in strategy occurred in July 1864, with the appearance of the New Orleans Tribune, the paper that succeeded L'Union, which had ceased publication in July 1864. With the Tribune, especially after Charles J. Dalloz became its editor in November 1864, the black population of Louisiana acquired a paper of national importance and influence. 52

In November of 1864 , the Tribune found in the so-called Quadroon's Bill, introduced in the state legislature by Senator Charles Smith, an issue around which it could rally the entire black population. Senator Smith's bill would define as white all persons who had one quarter or less African blood. The Tribune opposed the measure as both unjust and absurd. If the bill passed, the paper believed, it would have the effect of dividing the black community at a time when it was crucial for all blacks to stand up for universal suffrage. As the Tribune argued, a true republican form of government could not exist without complete freedom and complete freedom was impossible without equality before the law and at the ballot box. ${ }^{53}$ The Negro paper considered the bill an attempt to avoid the real question: what are the rights of the black population? Why should a light skinned minority be allowed to vote, when thousands of their darker brothers had been fighting for the Union 
and fulfilling all the requirements of citizenship? The Tribune sternly opposed the Smith bill, and two weeks later attacked Smith's new proposal, which would have granted the right of suffrage to all black people according to the limits stipulated by Article 15 of the state constitution. 54 Although the new bill would have enfranchised all blacks who had served for one year in the Union army, who could pass a literacy test, or who paid $\$ 30$ a year property tax, the Tribune refused to be satisfied with half-measures. It demanded that the black population be subject to the same laws that governed the white voters. 55

Despite Hahn's support, bills to grant suffrage to blacks qualifying under the new constitution were twice rejected by the state senate, 20 to 4 , and 15 to 5 . Arguments against such bills reveal a great deal about the underlying anxieties pervading Louisiana politics during the early Reconstruction era. Opponents said the bills, if passed, would make Negroes "our equals in society." Since they formed a majority in the country parishes, with the right of suffrage, "they would control all elections, claim for themselves all public offices, and from a position of servitude assume one of mastery." 56 Meanwhile, the Era acknowledged that "the constitution has given the Legislature power to extend the right of suffrage to any class who may deserve it, either by intellectual fitness, military service or taxation, for the support of the Government," but the paper concluded that "in our judgement the whole subject should rest for the present and it should be unreasonable and inexpedient for the General Assembly at its present session, to attempt so radical a change in our system of laws." 57 
The attitude of the legislature over the suffrage question showed both the prejudices and misunderstanding entertained by the Free State leaders concerning the political force represented by the black population. The political potential of the blacks was evident during the fall of 1864. Black leaders had founded in September the National Equal Rights league of Louisiana and had in November called a convention of the N.E.R.L. of Louisiana to meet in New Orleans in early January 1865. The convention assembled on January 9, 1865, at Liberty Hall in New Orleans. The eighty-six delegates represented country parishes, such as Assumption, Baton Rouge, Jefferson, Lafourche, and Terrebonne, as well as the Crescent City. Although the New Orleans. Times insinuated later that the convention was made up of illiterates, ${ }^{58}$ the New Orleans Tribune was closer to the reality when it observed:

There were seated side by side the rich and the poor, the literate and educated and the country laborer, hardly released from bondage, distinguished only by the natural gifts of the mind. There the rich landowner, the opulent tradesman, seconded motions offered by humble mechanics and freedmen. Ministers of Gospel, officers and soldiers of the U.S. army, men who handle the sword or the pen, merchants and clerks,--all the classes of society were represented, and united in a common thought: the actual liberation from social and political bondage. 59

A study of the background of each conventionist shows that at least 32 delegates, or 37.2 percent, had served or were serving in the Union army and 52 , or 60.4 percent, were free blacks before the War. Moreover, information uncovered about the occupations of 65 of the 86 delegates shows that most were artisans, businessmen, or professionals. (See Table II.3). 
Table II.3

Occupation of the Participants at the N.E.R.L. Convention held in New Orleans in January 1865

Known-Occupation

Laborer

Skilled worker

- sea related

- industrial workers

- building trades

- clothing trades

- domestic trades

- barber

Small store Owner

Small Professional (clerk)

Merchant

Planter

Professional

- lawyer

- doctor

- teacher

- minister

- musician
Number

10

26

\section{Percentage}

15.4

40.0

Total

5

7.7

3

4.6

6

9.2

1

1.5

14

21.5

Sources: Gardner's New Orleans City Directory, for 1861, 1865, 1866; Census Reports, New Orleans, 1860, 1870, Microfilm Room, National Archives; New Orleans Tribune, January 9 to January 15, 1865. 
After protesting against the discrimination on the New Orleans City street cars, ${ }^{60}$ the delegates heatedly debated whether or not to petition the state legislature for suffrage. The main objection came from those who pointed out that the state legislature could only accord a limited suffrage in accord with Article 15 of the constitution. Debate continued for three days. The petition was finally rejected by a vote of 51 to 22,61 after both Thomas J. Durant and Capt. James H. Ingraham spoke against it. Durant, appearing at the request of the delegates, argued that only Congress had the authority to enfranchise the black population and that the delegates could not expect the legislature to grant what the 1864 convention had expressly opposed. 62 The convention adjourned on January 14, after five days of hard work, but the N.E.R.L. had split over the petition issue. A group seceded and decided against the will of the majority to petition the Legislature. ${ }^{63}$

Still the convention had several accomplishments to its credit. It had taken the major step of providing the black population of Louisiana with a permanent executive organization, the Central Executive Committee of the National Equal Rights League of Louisiana, to which it added committees on industry and information. Moreover, the convention had indicated the determination of the National Equal Rights League of Louisiana to play a major role in the "promotion of moral development, education and industry" of the freedmen. ${ }^{64}$ It had also demonstrated the growing radicalism of the free blacks by inviting Thomas J. Durant to become a member of the convention and the N.E.R.L., while it refused to grant B.R. Plumly the same honor because he supported General Banks' policy. Finally, the convention had revealed, as the Tribune observed, 
the blacks' distrust and contempt for the Free State government by refusing even to petition the legislature. 65

On February 17, 1864, A.C. Hills attempted to introduce a suffrage petition signed by 5,000 blacks, whom the isew Orleans Tribune described as "illiterate laborers." 66 The proposal of Hills was met by a storm of opposition in the Legislature. ${ }^{67}$ Senator J.P. Montamat, declaring himself "a native of Louisiana," announced that "when this State extends to negroes the right of suffrage. . . he. . . should leave it forthwith and go to live in China." Senator J.D. O'Connell with the approval of the president of the senate, Lieutenant-Governor Wells, launched a lengthy attack against T.J. Durant, as a way of impeding the debate over the suffrage question. ${ }^{68}$ Despite the demonstrated unwillingness of the legislature to extend the right of suffrage, one prescient observer, G.S. Dension, foresaw the political dynamics set in motion by emancipation. Denison wrote to Chase, "The result, I think, will be, that when the rest of the State comes in, the opposite party strives to get the power, the present dominant party through the Legislature, will immediately confer suffrage on all. colored men, so that by their assistance they may retain control of public affairs." 69 Dension was correct; in due course, Senators Montamat and $0^{\prime}$ Connell themselves became advocates of Negro suffrage.

The question of suffrage was one of the most difficult problems that Governor Hahn had to face during the fall and the winter of 1864-1865. But it was not the only one or even the most delicate. The departure of General Banks on a leave of absence in September 1864 uncovered the precarious and uncertain character of the relationship between the new 
state govermment and the military authorities. General Hurlbut, who had temporarily superseded Banks as commanding officer of the Gulf Department in September, was much more favorably disposed toward Louisiana's conservative Democrats than he was toward the Hahn faction. The new and more conservative order of things became clear almost immediately after the departure of General Banks when members of the Hahn faction, clashing with Hurlbut, sent North a series of complaints about military interference and urged President Lincoln to return Banks to Louisiana. ${ }^{70}$

As one discouraged Free Stater wrote Banks, "your friends are prostrated here, at present. This pretorian rule of West Point may be good for the field or for West Point or for a frontier, but it is ruinous to the policy of restoration." 71 Hahn himself wrote Banks that "the new regime (military) and myself do not get along smoothly. Indeed I feel so that if the present military authorities were to continue to remain and to act for any length of time, I should resign and retire into private life." "The expectation of seeing you here soon gives me courage to bear what I should never bear under any other circumstances," Hahn added. "The authorities here appear determined to kill off any reorganization of a loyal state Government." 72

The political realities underlying this correspondence were complex. The conservative orientation of General Hurlbut was an irritation but not a decisive factor. The chief complaint against him was that he seemed to feel no compulsion to cover up any schemes of corruption or fraud in order to prove that Louisiana had been successfully reorganized. In fact, to the great anxiety of Governor Hahn, he tended to do just the 
opposite by pressing the question of whether or not fraud lay behind the remarkable cost of the 1864 convention. 73 This tack, or course, was unacceptable to such a friend of freedom as Governor Hahn.

The complaints of the Hahn faction did not fall on deaf ears. On November 14 Lincoln sent Hurlbut a harsh letter criticizing the bitter military opposition to the new State Government of Louisiana. Lincoln noted that what had been done "was done under military protection, directed by me, in the belief, still sincerely entertained, that with such a nucleus around which to build, we could get the State into position again sooner than otherwise" and that "in this belief a general promise of protection and support, applicable to Louisiana and other States, was given in the last annual message." The President observed that since "every Unionist ought to wish the new goverment to succeed; and every disunionist must desire it to fail," such military opposition seemed incomprehensible. Though the President maintained that "the military must not be thwarted by civil authority," he added carefully that he did not mean that the military should interfere with purely civil affairs. He concluded pointedly that should the military commander have "a purpose obvious, and scarcely unavowed, to transcend all military necessity, in order to crush out the civil government," this unwanted intrusion "will not be overlooked." 74

In his reply to President Lincoln, General Hurlbut stood his ground, thought he confessed he was "much surprised at the tenor and spirit" of the President's letter. Hurlbut said the President could only have been misinformed about the situation in Louisiana. Since the adoption of the constitution nothing has been done concerning the important question of 
the freedmen, "except by military authority"; neither the executive nor the legislature has done "a single thing for their benefit or offered to take the charge off our hands." Hurlbut recognized the work of the constitutional convention as "one of great merit and of vast importance at the time when it was accomplished," but he did not think he should entertain for the individual members of that body "any other sentiments than those which their conduct deserves." Hurlbut also felt it necessary to inform the President that "the State of Louisiana is not a loyal State not by any means 'as loyal as the State of Massachusetts'," contrary to what General Banks had affirmed in the North. "We hold our tenure in the State by the bayonet, and the region so held is limited by actual occupation. . . the City of New Orleans is practically the State of Louisiana." General Hurlbut concluded his letter with the sober prediction that "the State Government can never successfully go into operation until armed resistance ceases." 75 On December 1, 1864, General Hurlbut repeated these charges in a lengthy letter to Governor Hahn, and dismissed the Governor's protests concerning military interference. ${ }^{76}$ The only answer that the Governor could make to the charges of the commanding officer of the Department was that he could not be held responsible for the machinations of legislators. 77

Following that exchange of letters, Hahn wrote to Lincoln that the situation and his relationship with General Hurlbut had greatly improved. Still, they were both far from sharing the same views concerning the state's political reorganization. ${ }^{78}$ The conflict over jurisdiction persisted up to the moment that Lieutenant-Governor J.M. Wells succeeded Hahn in the gubernatorial office on March 4, 1865. Even then, General Hurlbut, although he had developed a good working relationship with the 
new governor, held to the opinion "that the convention, and the Legislature and officers created by it are the creatures of the Executive authority exercised through the. . Commanding General." 79

The situation facing all parties was complicated by the assumptions of the distant President in Washington. Hurlbut's control over civil affairs was limited by the President, while the military authorities were still held ultimately responsible for any mischief committed by the civil authorities. In an effort to clarify these problems of authority, Hurlbut dispatched to Lincoln a series of charges against the Legislature, describing that body as "entirely useless, very expensive, and liablé to do serious harm by its legislation." It had not "originated any measures for the public good" but only increased the public debt after having spent "all the money in hand." Hurlbut concluded that this useless legislature, coupled with the fact that a large part of the state was under rebel control and that a large number of rebel sympathizers were within Union lines, made it "unsafe to the government to permit the exercise of the function of sovereignty by the people of Louisiana under their State Government." 80 The Free State party countered these charges by rightly accusing General Hurlbut of "pushing all re-actionary measures with the bayonet" and of "pressing out of civil place, all men suspected of adhesion to the Free State, and pressing in old semi-rebels, and copperheads, one of them at least, a registered enemy." 81

The civil-military dispute was, however, temporarily set aside in March 1864 with the accession of Lieutenant-Governor James Madison Wells to the gubernatorial chair. Given his poor relationships with the 
legislature and the military authorities during the fall of 1864 , Governor Hahn felt that his future in state politics was dim. Therefore, he graciously accepted his election by the legislature to a six year term in the United States Senate. Although Louisiana had been, during the year of Hahn's incumbency, reorganized with a new state government, a new legislature, a new judiciary, and a new constitution, the experiment had many negative sides. In spite of strong pressure from the President, from the Louisiana delegation, from General Banks and Governor Hahn, the Congress had remained adamant in refusing to recognize the legitimacy of the new state government, which was limited in its jurisdiction largely to the city of New Orleans, and was mainly an appendix of the military authorities, which remained the ultimate master of the situation. Moreover, in its first and only year in office, the Free State government had been discredited by corruption, fraud, and insensitivity to the public interest. The Hahn-Banks faction did not at first see that the change of governor would bring an immediate change of policy which would put to an end the Free State experiment. Following the election of Governor Hahn to a United States Senate seat, the True Delta wrote that Wells "has shown himself a man of firmness, patriotism and fitness for the position, The people of Louisiana may well feel proud of such a man as Lt Gov Wells and fortunate that their first office falls in such safe and reliable hands." 82 
'Banks' involvement in Louisiana politics postponed his departure for the Red River until March 18.

2Durant to Chase, January 16, 1864, Chase Papers, LC.

3Durant to Chase, March 5, 1864, Chase Papers, LC; see also Durant to Davis, March 31, 1864, Durant Papers, NYHS.

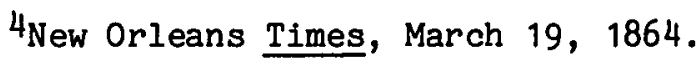

5 Among those who ran on their own on the Free State Citizens ticket, an alliance of radicals and conservatives, were prominent radicals such as C.W.Hornor, the law-partner of Durant, Judge Ezra Hiestand, who joined the Hahn faction in the summer of $1864, \mathrm{Dr}$. James Ready, Judge J.S. Whitaker, and Alfred Jervis. Only Judge E.H. Durrell and Judge R.K. Howell, who had supported Flanders in February 1864, ran on the moderate ticket. See New Orleans Picayune, February 12, 13, 1864; New Orleans Bee, February 12, 13, 1864; New Orleans Times, March 27, 28 , 1864 .

$6_{A}$ copy of the official return of the convention election is found among miscellaneous documents of the Smith-Brady Report, Box 1, RG 94, War Department, National Archives.

7Hahn to Lincoln, April 2, 1864, Lincoln Papers, LC.

${ }^{8}$ This pejorative characterization originated among the radicals. See Denison to Chase, April 1, June 17, July 26, October 8, 1864, Whitaker to Chase, April (?) 1864, Tucker to Chase, December 10, 1864, Chase Papers, LC; New Orleans Times, May 3, June 24, 30, 1864; New Orleans Era, May 25, July 1, 23, 1864.

9Historians have offered two major interpretations of the social composition, the political background, and the administrative capacity of the 1864 convention delegates. J.R. Ficklen and W.M. Caskey, following the conservative tradition generated by William Dunning, have described the 1864 conventionists as "a motley assemblage of yankee adventurers and natives of low social status", while Robert W. Shugg pictured the Free State convention of 1864 as the first native radical body to express the economic grievances of the white farmers and workers of the South. James P. McCrary, in "Moderation in a Revolutionary World", was the first to question those two interpretations by pointing out that the 1864 convention was composed neither of yankee adventurers and poor whites nor of native radicals, instead it was an overwhelmingly middle class body, its members drawn from the business or the professional community. Caskey, Secession and Restoration, 116-40; J.R. 
Ficklen, History of the Reconstruction in Louisiana, 67-87; F.H. Harrington, Fighting Politicians, 140-150; J. P. McCrary, "Moderation in a Revolutionary World", 281; R.W. Shugg, Origins of Class Struggle in Louisiana, 196-210; J.G. Taylor, Louisiana Reconstructed, 44. (Baton Rouge, 1939).

10 Among those 5 Confederate officeholders were two members of the Louisiana rebel legislature of 1861 , O.W. Austin and J.V. Bofill.

${ }^{11}$ It is worth noting that the conservative press, especially the New Orleans Bee and the New Orleans Picayune, could hardly criticize General Banks policy or the convention without being censured or suspended as the Picayune had been for two months in summer 1864 . Even the radical Times editor, Thomas $P$. May, was arrested by order of the convention for having described the disturbances caused in the convention hall by the drunkeness of many delegates on July 22. See Debates in the Convention for the Revison and Amendment of the Constitution of the State of Louisiana (1864). New Orleans, 1864, 609 (hereafter Convention Debates).

12New Orleans Times, April 17, 20, 22, 29, May 3, 4, 17, June 20, 24,30 , July 1, 22, 1864.

13 New Orleans Era, April 14, 20, 23, 26, 27, June 15, 19, July 1, 23, 1864; see also True Delta, July 23, 1864; Denison confirmed the fact that the convention had sunk to a low-level of ridicule, when he informed Chase that "in the public estimation, General Banks' State Convention stands no higher than Banks himself, 'What fools they are making of themselves' is a very common remark, even among those who helped to elect them" Denison had been a supporter of Banks in early 1864. Denison to Chase, June 17, 1864, Chase Papers, LC.

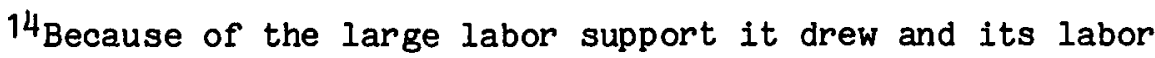
clause, Shugg described the 1864 constitution as an "extraordinary document which contained reforms and innovations of great social import." R.W. Shugg, Origins of the Class Struggle in Louisiana, 203.

15Denison to Chase, June 17, October 8, November 25, 1864, Tucker to Chase, December 10, 1864, Whitaker to Chase, December 16, 1864, Chase Papers, LC.

${ }^{16}$ Convention Debates, 139-205, 210-225, 233-250, 473-480.

17 Convention Debates, 182, 214, 218, 246.

${ }^{18}$ Convention Debates, 158.

19 McCrary divides the convention between 21 hard-line liberals, 21 others who are liberal, except for the question of suffrage, another group of 20 who supported emancipation but tended to oppose education or suffrage for blacks, and a last group of 21 hard-line conservatives. J.P. McCrary, "Moderation in a Revolutionary World," 302-3.

${ }^{20}$ Ibid., 303-4. 
21 Ibid., 300-317.

22Ibid., see also Convention Debates, 221-24, 631-43; Convention Journal, 74, 91-100.

230n May 9, Abell presented the motion that the legislature would not be allowed to grant suffrage to blacks; this motion passed, only to be rescinded the following day by a vote of 59 to 23, but it was only 6 weeks later that Joseph Gorlinski presented the motion that the legislature should be allowed to grant limited suffrage to blacks who could qualify by intelligence, property or military service (see McCrary, "Moderation in a Revolutionary World," 310-12; Convention Debates; 450, Journal Debates, 130; F.H. Harrington, Fighting Politicians, 148; J.R. Ficklen, History of Reconstruction in Louisiana, 71-2; J.G. Taylor, Louisiana Reconstructed, 47-8; W.M. Caskey, Secession and Restoration, 128-130; G.M. Capers, Occupied City, 229). On April 1, 1864, Denison had written to Chase that he did not expect "there is much propect that the Convention will extend the elective franchise to free persons of color. If it is not done, the responsibility should rest on Gen. Banks, for the Convention is composed mostly of persons who would do whatever he should request." (Denison to Chase, April 1, 1864, Chase Papers, LC). The sudden and rather strange change, if we consider their prejudices, in the attitude of the conventionists on the suffrage issue has sometimes been explained by historians as a consequence of pressure from General Banks. That General Banks did socialize often with the conventionists while the convention was working, that the conventionists were mostly his picked men and that he could influence them, are all obvious facts. The conservative delegate at the convention, Edmund Abell, testified before the Smith-Brady Commission that the change of vote in the suffrage question did occur at the convention only after some interference and pressure had been exerted, and that several of those who changed their vote did it because they felt "they might be injured by voting as they had done." George A. Fosdick, a liberal delegate, was even more explicit in his testimony before the same Commission, when he said that he did not know anything about any interference of General Banks but that he did know that in order to get the article on suffrage through, Governor Hahn promised many delegates either an office or a seat in the Legislature for those who would change their vote. Fosdick then presented a list of 22 delegates who held office before the convention convened and 17 who were appointed after. (See Warmoth Papers, Diary, May 31, 1864, University of North Carolina Archives "UNCA"; Denison to Chase, October 8, November 25, 1864, Whitaker to Chase, December 16, 1864, Chase Papers, LC; Smith-Brady Report, War Department, RG 94, Box 7, J.E. Neelis testimony, May 4, 1865, E. Abell testimony, April 21, 1865, Box 15, George A. Fosdick Testimony, April 27, May 1, 1864, Joseph G. Baum testimony, May 2, 1865).

${ }^{24}$ Lincoln to Hahn, March 13, 1864, in Lincoln and Banks Papers, LC.

25 This confirmed the testimony of Fosdick before the Smith-Brady Commission. See War Department, RG 94, Smith-Brady Report, Box 15, Fosdick testimony, April 27, May 1, 1865. 
26 Ibid.

27Convention Debates, 623-24; Denison to Chase, July 26, 1864 , Chase Papers, LC.

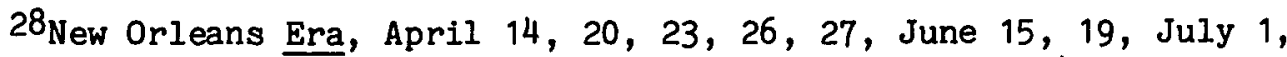
23, 1864; New Orleans Times, April 17, 20, 22, 29, May 3, 4, 17, June $20,24,30$, July $1,2,22,1864$.

29 Hurlbut to Hahn, October 20, 23, 1864, Hurlbut to Dostie, October 22, 1864, Hahn to Hurlbut, October 23, 1864, Dostie to Hahn, October 31, 1864, Lincoln Papers, LC (those letters are also in War Department, Gulf Department, M 1738, General Correspondance); Hurlbut to Lincoln, November 29, 1864, Lincoln Papers, LC; The State Auditor Report, September 30, 1864.

$30 \mathrm{New}$ Orleans Era, October 27, 29, 1864, New Orleans Times, October 26, 28, 29, November 5, 1864.

31 Debates in the Senate of the State of Louisiana, Session of 1864-(1865), New Orleans, 1864 (hereafter as Senate Debates, 1864-1865), October $31,1864$.

32The True Delta, which had been sold to Hahn, Shaw and Fish in January 1864, was after the February 1864 election officially owned by W.R. Fish, but evidence shows that Governor Hahn and Sheriff A. Shaw kept their share in the ownership of the paper. after they became officeholders. See George Fosdick testimony, April 27, May 1, 1865, Alfred Shaw Testimony, April 27, 1865, C.W. Hornor Report, May 6, 1865, Box 7, 15, Smith-Brady Report, RG 94, War Department, N.A.

33John Foley to General Hurlbut, November 23, 1864, and Memorandum of General Hurlbut, April 13, 1865, Box 15, Smith-Brady Report, RG 94, War Department, N.A.; Debates in the House of Representatives in the State of Louisiana, Sessions 1864-1865, November 3, December 9, 20, 1864; New Orleans Times, December 10, 21, 1864; New Orleans Tribune, December 10, 21, 1864.

${ }^{34}$ Denison to Chase, September 6, 1864, Chase Papers, LC.

35 Banks to Dostie, August 23, 1864, Banks Papers, LC.

$36_{\text {Banks }}$ to Lincoln, July 25, 1864, Lincoln Papers, LC.

37Lincoln to Banks, August 9, 1864, in Lincoln Papers, LC, and in Banks Papers, LC.

${ }^{38}$ New Orleans Plcayune, August, September 1864; New Orleans Tribune, July 25, 26, 28, August 6, 9, 13, September 1, 1864; Gerard Stith, a printer, and A. Morris Hanksworth, the owner of the Picayune, testifled that Banks forced the paper to publish as if they were from the Picayune two editorials on August 24 and September 3, 1864, in 
support of the convention. Stith Testimony, May 1, 1865, Hanksworth Testimony, April 29, 1865, Box 7, 15, Smith-Brady Report, RG 94, War Department, N.A.

39 New Orleans Times, September 1, 5, 1864; New Orleans Era, July 27, August 3, 4, 12, 17, 25, 27, 1864; New Orleans True Delta, August 7, $9,10,11,17,19,21,1864$.

40 New Orleans Era, September 1, 1864; New Orleans Picayune, May 4, 27, 1865; New Orleans Times, April 13, 14, November 4, 1865; New Orleans Tribune, April 15, 1865.

${ }^{41} \mathrm{Hills}$ to Banks, September 2, 1865, Banks Papers, LC.

42 Hahn to Lincoln, November 23, 1864, Lincoln Papers, LC; New Orleans Era, September 21, 1864.

43 In his letter to Senator Lane, on September 24, 1864, Banks resorted to the same arguments in explaining the result of the election. In January 1864, Banks and the different representatives elected to Congress at the September 5, 1864, election again used those same arguments in an attempt to defend the Banks-Lincoln policy in Louisiana and to win the congressional recognition. The Banks-Hahn party acknowledged that 1178 soldiers, which meant $14 \%$ of those who cast a vote, voted at the election; but in attempting to minimize that vote, they emphasze that compared to the election of February 22, 1864, rested on the fact that Banks could not force the 3500 to 4000 supporters of the McClellan interest and the 2500 supporters of $\mathrm{Mr}$. Durant to vote. But they could not without great difficulty reject the hard fact that out of 48 parishes in Louisiana, only 19 voted, leaving 29 unrepresented, and that out of 8000 votes, the parish of New Orleans cast 6500 , while only 1500 came from the rest of the state. These facts brought the congressional minority report to conclude that "In view of the facts, it may be truly averred that the people of Louisiana did not participate or concur in the establishment of the Government presented for recognition." See Letter of Major-General N.P. Banks to Senator Lane, "The Reconstruction of States," N.Y. Harper Brothers, 1865(4), LC; This letter was also widely published in the different papers of New Orleans on September 24, 1864; House Report no 13, Louisiana Election Case, 38th Congress, 2nd session, pp. 7-10, 37; New Orleans Era, September 23, 1864.

${ }^{44}$ New Orleans Tribune, April 14, 15, 1865; See also letter of J. Randall Terry to Governor Wells, March 6, 1865, included in Louisiana Legislative Documents, 1 session of the Second Legislature of the State of Louisiana, New Orleans, 1866.

45 Seicshnaydre testimony, April 20, 1865; Abell testimony, April 21, 1865; Terry testimony, April 30, 1865; Candellack testimony, April 21, 1865; Ames testimony, April 21, 1865; Leaumont testimony, April 22, 1865; D'avignon testimony, May 1, 1865; Russ affidavit, September 13, 1864; letter of E. Abell to M.F. Bonzano, October 1864; C.W. Hornor report, May 6, 1865; Stulia testimony, May 3, 1865. Crane testimony, 
May 2, 1856; Hanksworth testimony, April 29, 1865; Lynch testimony, May 1, 1865; all those testimonies, letter and affidavit are in Box 7 and 15 of the Smith-Brady Report, RG 94, War Department, N.A.

46 See Report of the Committee on election of US Senator Hahn and Cutler, Documents of the First Session of the Second Legislature of the State of Louisiana, New Orleans, 4, 6, 7; C.W. Hornor report, May 6 , 1865, Smith-Brady Report, Box 15, RG 94, War Department, NA.

47Denison to Lincoln, September 28, 1864; Bullitt and Terry to Lincoln, September 6, 12, 1864; Hahn to Lincoln, September 24, October 28, November 5, 1864; Banks to Lincoln, October 28, November 8, 1864; Lincoln Papers, LC.

48 Senate Debates, 1864-1865; House Debates, 1864-1865; "Administration of the Mayors of New Orleans," City Archives, New Orleans Public Library; Gardner's New Orleans City Directory for 1861; New Orleans Bee, 1850 to 1866; New Orleans Picayune, 1850 to 1866; New Orleans Times, 1863 to 1866; New Orleans Tribune, 1864 to 1866.

49J.V.C. Smith to N.P. Banks, February 20, 1865, Banks Papers, LC; New Orleans Picayune, April 6, 1865; New Orleans Times, February 14, $15,17,21,1865$; New Orleans True Delta, March 21, 1865.

50 P.M. Tournee to Banks, July 30, 1864, P.M. Tournee to John F. Collins, August 12, 1864, Conway to Roudanez, August 19, 1864, Banks Papers, LC; New Orleans Tribune, July, August, 1864: D.E. Everett, "Demands of the Free Colored Population of New Orleans," 54; C.P. Ripley, Slaves and Freedmen in Civil War Louisiana, 174.

${ }^{51}$ The free black population of New Orleans would have been satisfied if the 1864 convention had extended suffrage in accordance with Lincoln's letter to Governor Hahn, but the reluctance of the convention to do so pushed the free blacks a step further in their radicalization. The free black population did not want at first to assimilate its cause with the cause of the black population as a whole. (see J.C. Houzeau, "Journal Noir, aux Etats-Unis," 8-12). Still in July 1864, Tourne wrote to Banks about the new General Order of General Canby concerning the militia: "In the General Order of General Canby for the enrollment of the State militia, how are we to be classed? I hope we are not to be enrolled with the blacks." July 30, 1864, Banks Papers.

52 Charles J. Dalloz was the pseudonym of Jean C. Houzeau, a white radical and socialist Belgian who had been forced to leave Europe in the 1850 's because of his radicalism and came to live in America from 1858 to 1870 . Thoroughly a humanist, Houzeau was strongly opposed to secession and slavery; when the war broke out, he escaped from Texas and arrived in New Orleans in February 1863. He was in Philadelphia in October 1864 when $\mathrm{Dr}$. Roudanez, a free black and co-proprietor of the Tribune with Paul Trevigne, another free black, asked him to take the direction of the paper. Houzeau followed the progressive views already expressed by Roudanez, but gave to the paper its clear radical approach on social, political, and economic questions for the next four years. J.C. Houzeau, "Journal Noir," 15. 
53 Senate Debates, November 14, 16, 1864; New Orleans Era, November $17,1864$.

$54 \mathrm{New}$ Orleans Tribune, November 10, 11, 12, 15, 16, 19, 1864;

J.C. Houzeau, "Le Journal Noir," 11-16; J. McPerhson, The Negro's Civil War, (New York, 1965), 283-4.

$55 \mathrm{New}$ Orleans Tribune, November 19, 1864; J.C. Houzeau, "Le Journal Noir," 11-12.

56 Senate Debates, November 14, 16, 1864.

57 New Orleans Era, November 17, 1864.

58 New Orleans Times, January 26, 1865; New Orleans Tribune, January $27,1864$.

${ }^{59}$ New Orleans Tribune, January 15, 1865.

${ }^{60}$ New Orleans Tribune, January 13, 1865.

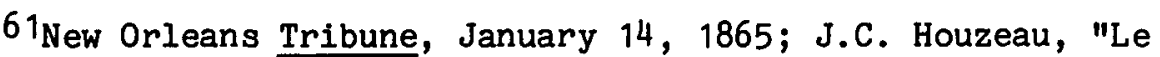
Journal Noir, " 21-22.

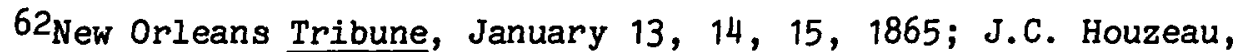
"Le Journal Noir," 21-22.

63New Orleans Tribune, February 15, 1865; C.P. Ripley, Slaves and Freedmen in Civil War Louisiana, 179-80.

${ }^{64}$ New Orleans Tribune, January 13, 14, 15, 1865.

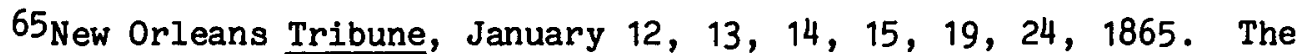
True Delta, the paper of Governor's Hahn administration, saw clearly the radicalization of the black population when it said: "We regret to perceive that there is a disposition, on the part of many intelligent delegates, to assume an attitude of hostility to the present Free State Government, and to make an appeal direct to Congress. Ignoring the fact that the late Convention of 1864 took a step in the cause of the colored man of gigantic proportions, and, with one blow, shattered his chains, they now accuse them of having been inimical to the race that has, so far, failed to obtain the full recognition of its civil rights." True Delta, January 15, 1865; in the same way, the radical special supervising agent of the Treasury, B.F. Flanders, reported to Chase: "It would not surprise me if the Convention of intelligent colored men, now in session here, should make a declaration of their distrust of the Union Government." Flanders to Chse, January 10, 1865, Chase Papers, PHS; On January 24, 1865, the Tribune harshly criticized the Free State party for having given the freedmen only freedom in words, not in deeds. The Tribune specified that real freedom should mean the right to go and come everywhere at will, the right to vote, the right to an education, the right to hold public office, and the enjoyment of all civil rights in Court. 
${ }^{66}$ New Orleans Tribune, February 19, 1865.

67Senate Debates, February 17, 1865, 157-171; Black Republican, April 15, 1865; W.E.B. DuBois, Black Reconstruction, 159.

${ }^{68}$ Senate Debates, February 17, 1865, 157-171.

69Denison to Chase, November 25, 1864, Chase Papers, LC.

$70_{\text {Hahn }}$ to Lincoln, September 24, 1864, Lincoln Papers, LC.

$7^{1}$ Plumly to Banks, October 8, 1864, Banks Papers, LC; see also Plumly to Mrs. Banks, October 26, 1864, Banks Papers, LC.

72 On October 29, 1864, Hahn complained directly to Lincoln that "the military officers now in power in this Department seem not only to ignore all civil authority, but their acts look as if they were determined to prevent the organization of a loyal state Government, and to extinguish as much of it as has been established," He concluded by demanding that the President make "no delay in sending Genl Banks, or some man to take the charge of the Department of the Gulf who will have the power and the desire to aid us." Hahn to Lincoln, October 29, 1864, Lincoln Papers, LC; see also Hahn to Banks, October 28, 1864, Banks Papers, LC.

73Hurlbut to Hahn, October 20, 23, 1864; Hurlbut to Dostie, October 22, 1864; Lincoln Papers, LC; Memorandum of General A.S. Hurlbut, April 13, 1864, Box 15, Smith-Brady Report, RG 94, War Department, N.A.

${ }^{74}$ Lincoln to Hurlbut, November 14, 1864, Lincoln Papers, LC.

75Hurlbut to Lincoln, November 29, 1864, Lincoln Papers, LC.

76 Hahn to Hurlbut, December 1, 1864, Hurlbut to Hahn, December 1, 1864 , in M 1738, General Correspondence, Gulf Department, War Department, N.A.

77Hahn to Hurlbut, December 5, 1864, M 1738, Gulf Department, War Department, N.A.

${ }^{78} \mathrm{Hahn}$ to Lincoln, December 2, 9, 1864, Lincoln Papers, LC.

79Hurlbut to Lincoln, March 15, 1864, Lincoln Papers, LC.

80 Ibid.

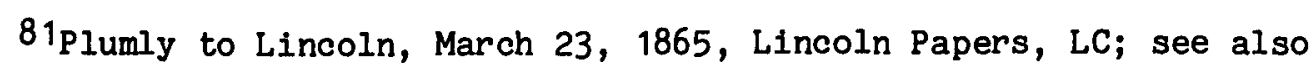
Field to Lincoln, March 16, 1864, Lincoln Papers, LC.

82New Orleans True Delta, January 10, 1865. 


\section{CHAPTER III}

Wells' Conservative Policy

The inauguration of James Madison Wells meant both a change of Governor and a change of style and policy. Governor Wells was a wealthy planter of Rapides Parish who has been pictured by historians as a master of tergiversation and dissimulation, the Talleyrand, in fact, of Louisiana politics. Once in office, Governor Wells, who had heretofore avoided taking a stand on the major issues of the day, broke openly with the policy of his predecessor by launching a conciliatory policy that would oust from office the Hahn proteges and ultimately would bring to power the conservative and ex-Confederate elements. By the end of summer 1865 Governor Wells seemed in full control of the political situation in Louisiana, in spite of the factional opposition of moderates and radicals.

The new governor made the speedy reestablishment of complete civil government and the "resumption of Louisiana's relations with the Union" the main goals of his administration. Wells described his policy as an attempt to find a middle ground between two extremes: Rebel and Yankee adventurers, who wanted to enrich themselves at the cost of the South. ${ }^{1}$ Wells proclaimed in his inaugural address his intention to forget and forgive past views and actions and to grant political favors and offices on the basis of merit and capacity. 
In attempting to implement his conciliatory policy, Wells quickly discovered that the power of the Governor was limited by martial law. Consequently, Wells, in order to consolidate his power and to gain control of apppointive offices then under military jurisdiction, repeatedly urged President Lincoln and then President Johnson to appoint him Military Governor of Louisiana. Throughout the summer of 1865 he waited and hoped to receive the nomination. On March 6, 1865, two days after he became Governor, Wells asked Lincoln to confer on him the same military power that Hahn had enjoyed. Wells argued that "such power is absolutely necessary to provide for the exigencies of our situation" and that without it he "should be powerless to make appointments of civil officers." On April 28, 1865, complaining of military interference, Wells made the same request to President Johnson. 2

Although Wells had declared in his inaugural address his intention to call to his aid "the best and ablest men of the state, " 3 once in office, it became increasingly obvious that the new governor intended to build a political party by appointing his own men to key judicial and political positions in the state and in the city of New Orleans. He relied for advice and support on old Democrats, such as $\mathrm{Dr}$. Hugh Kennedy, Dr. Thomas Cottman, and United States Marshal Cuthbert Bullitt. Thus he linked himself to the old planting and commercial interest of the city, ${ }^{4}$ the group that had supported Fellows, the conservative candidate for governor, in February 1864. Since the control of the city administration was the cornerstone of his political strategy, Wells appointed his friend, Dr. Kennedy, ${ }^{5}$ as Acting Mayor of New Orleans replacing Major Stephen Hoyt. This was his first step toward acquiring 
control of the city. In a letter to General Stephen A. Hurlbut, the commanding officer of the Gulf Department, Wells explained:

\begin{abstract}
My idea is to select a citizen of the proper qualifications who is not an office seeker, who will not be a candidate for election by the people, and consequently will not use the patronage of the office to promote his own ends. 6
\end{abstract}

General Hurlbut warmly approved of that policy, and assured Dr. Kennedy of his support in the removal of any office holder who was either corrupt or incompetent. ${ }^{7}$ Once in office, Dr. Kennedy made clear his intention to implement a policy of economy and efficiency. To show that he meant what he said, he proceeded immediately to appoint Glendy Burke, an old city merchant, as chairman of the city finance bureau, an office previously held by Judge E.H. Durrell, the president of the 1864 convention. Following the direction given by Kennedy, Burke immediately proceeded to remold all the city administration by changes in personnel, salary cuts, and dismissals. Old Union men were removed from office under the suspicion that they had served in the Confederate army. For the same reasons, police lieutenants James Duane, Boyd Robinson, and W.D. Miller were dismissed, while the police force was reduced from 450 to 400 men and filled up largely with new appointees. ${ }^{8}$ These changes at the clty level were in accordance with Governor Wells' intention of breaking with the Hahn faction, and enlarging his own political base. Wells, in order to gain complete control of the political and electoral machinery of the State, had, meanwhile, ordered the dismissal of several key office holders. When necessary Governor Wells used the police to eject from their offices the state auditor, Dr. Dostie, the sheriff of the Parish of New Orleans, the clerk of the second District Court, the Registrar of Voters, the judge of the first District Court. He replaced 
them with conservatives, some whom had served in the secession convention and others in the Confederate army. ${ }^{9}$ Moreover, Wells declared the present registry of voters to be illegal, fraudulent, and void. He estimated at least 5000 voters were registered illegally, and ordered a complete new registration of voters. ${ }^{10}$ As Denison reported to Secretary of Treasury Hugh McCulloch, these actions made Wells master of the electoral process in Louisiana. As the New Orleans Picayune noted, a new registry was particularly important to achieve that goal and to undermine the influence of the Banks-Hahn faction:

They know their political doom is sealed under a new and legal registry of voters. Not only the power of the State Government promises to slip from their hands, but their hopes of grasping the fat offices under the City corporation have vanished into the air. 11

By the end of April and the beginning of May 1865, the conditions of affairs in New Orleans and in Louisiana were at the boiling point. The Hahn-Banks group were dismayed to see the lever of power slip from their hands just when the Union had crushed the rebellion. Fast-growing resentment among the members of the Free State party made confrontation between the Hahn-Banks faction and Governor Wells unavoidable. General Banks had returned to the city on April 20 and was ready to take the necessary action to protect his political friends.

The inevitable conflict came not because the Hahn-Banks faction refused to support a policy of reconciliation and forgiveness, but because the members of that faction were not ready to share the spoils of office. They were ready to compromise with the radical Durant group and the conservative Unionist element by creating a larger unity amorg Union men, as a way to reinforce their position, but they insisted that 
all office-holders had to be irreproachable unionists. ${ }^{12}$ The members of the Free State party held that the ex-rebels "should leave politics to men of more enlarged ideas and of more comprehensive understanding" and argued that they should, after having taken the oath of allegiance, serve an apprenticeship before they could be again allowed to have any political power and influence. 13

Henry C. Warmoth, a member of the Banks-Hahn faction, who was to become the notorious Carpetbag Governor of Louisiana in 1868, held a similar view when he wrote in his diary on May 14, 1865; "The City is full of returned soldiers and officers from Genl Lee's and Johnson's [sic] army. I suppose they expect to go into business \& take part in government affairs as if they had always been loyal citizens. ${ }^{14}$ on May 26, 1865, Warmoth had only harsh word for ex-rebels:

Will the men who instigated and propagated the wicked attempt at the national life be allowed to return home from the field of blood and carnage where hundreds and thousands of our brave boys sleep in the cold grave of death, with all of their bitterness and vindicationness [sic] which has been engendered for years and increased by the revolutionary conflict and soured upon them by failure and necessary acknowledgement of defeat, returned to cloth [sic] themselves in the garb of citizenship and exercise all of the rights, socially and politically that we enjoy, who have been through the din of battle and rivers of blood, the magnificent old flag which they sought to disgrace and destroy, heaven forbid. 15

The members of the Hahn-Banks faction adopted the dual strategy of pestering the Federal Administration in Washington with protests against the policy of Governor Wells and of pressing General Banks to remove Dr. Kennedy. ${ }^{16}$ On May 4, 1865, the committee of laboring men appointed on the $27^{\text {Th }}$ of April called upon General Banks and presented a long petition protesting against interference by city authorities and calling for 
the removal of $\mathrm{Dr}$. Kennedy. The following day, General Banks delivered a coup d'etat that divided the city between happiness and anger by ousting Dr. Kennedy and appointing Colonel S.M. Quincy as Acting Mayor of the city. In the following days, Colonel Quincy found himself assailed by a multitude of office seekers, since General Banks decided to reappoint many of those who had been previously removed. Colonel Quincy reported that all this was "done in accordance with the almost unanimous wish of the Union men of the City." 17

On May 17, 1865, Dr. Dostie, with the support of the Hahn-Banks faction, organized a large meeting in Lafayette Square in support of Andrew Johnson's policy and in opposition to Governor Wells. Judge E.H. Durrell presided and Col. T.B. Thorpe, H.C. Warmoth, A.P. Field, Judge Ezra Hiestand, and Dr. Dostie all spoke. The addresses, and especially the resolutions passed by the meeting, strongly opposed Governor Wells' lenient policy toward ex-Confederates. ${ }^{18}$

Governor Wells perceived that Banks's return to Louisiana had put an end to the close collaboration he had enjoyed with the military authorities. At the end of April 1865, Wells had already warned President Johnson that the continued existence of martial law eccentrically enforced could prevent the political machinery of the state from being fully restored. ${ }^{19}$ General Banks did what Governor Wells feared by removing $\mathrm{Dr}$. Kennedy. Wells decided to go to Washington, accompanied by Dr. Kennedy and Dr. Cottman, and present his case directly to the President. In one day Wells had seen destroyed everything he had patiently tried to build, so he decided to secure Banks's removal. "The Governor is enraged \& has gone to Washington to protest against military despotism" 
Quincy wrote to his mother. ${ }^{20}$ During his stay in Washington, Wells not only had Banks removed and replaced by General E.R.S. Canby, and Dr. Kennedy re-appointed as Mayor of New Orleans, but he also discovered that he and the President had similar ideas about reconstruction. 21 After several interviews with the President, Governor Wells wrote exultantly to his wife:

Tell the boys we shall not again be troubled with further yankee adventurism. Banks is the last and he is for ever killed off. - As has been proved to have been the case with this miserable man. . . prosperity has been too much for him--not accustomed to the society of decent people he knows not how to appreciate it. 22

Wells was unable, however, to convince the President to appoint him Provisional or Military Governor of Louisiana. It is worth noting that Wells met with President Johnson during the last week of May 1865, a few days before Johnson issued his proclamation of pardon and amnesty of May 29. This fact showed that Johnson intended to maintain a certain continuity with the policy of his predecessor. The new president could have satisfied Wells and appointed him Provisional Governor of Louisiana, but it would have undone the policy Lincoln had pursued in Louisiana. Consequently, Governor Wells was unable to obtain all the power he desired in his attempt to bring about a new reorganization of the state, although Johnson ensured him of the full presidential support and confidence. 23

Meanwhile, Governor Wells decided, as he told his wife, to pursue his conciliatory policy toward ex-Confederates and his conservative reorganization of the state government. "I as you know have constructed [sic] against the usurpation of both rebels and yankees and aboli- 
tionists and shall do so long as the right is granted."24 Moreover in order to smooth the return of Louisiana to the Union, Governor Wells issued a proclamation after his return from Washington urging the people the forget the past and to work together to build the future:

Whatever may have been the causes of the outbreak, and however, bitter may have been the feelings engendred in the hearts of some, it is better that all such matters be buried out of sight forever. It is not the past, but the present and future, we have to deal with. Great and responsible duties rest upon every citizen at this crisis, to manfully go to work and assist in the re-establishment of civil government. You must go to work to organize civil government in your respective parishes. Sheriffs, Recorders, Clerks of Courts, and police jurors, will have to be appointed provisionally, until elections can be held to fill these offices as provided by law. You must confer among yourselves and select men of integrity and capacity to fill these positions. I will act on your recommendation by appointing the person named by you, if they are men of proper character, and have taken the oath prescribed in the President's proclamation of the 8 th December, 1863, or that of the 29th of May 1865. This will be pre-requisite in all cases, the original or certified copy of which oath must be transmitted with the application for appointment. 25

In accordance with these principles, Governor Wells appointed a large number of ex-Confederates to important offices at the local level, especially in the country parishes. In a letter to the President, Governor Wells attemped both to justify his leniency and to answer the charges that he favored rebels over Union people. ${ }^{26}$ The popularity of Governor Wells' lenient policy among returned Confederates and some Union people was demonstrated in a large meeting organized mainly by Douglas Democrats and held in Lafayette Square on June 17, 1865. That meeting showed the strength and popularity of the governor; but it antagonized some members of the Free State party, who, led by Dostie, tried to disrupt the meeting, forcing the police to maintain order. ${ }^{27}$ 
Meanwhile, the Governor had asked General E.R.S. Canby, a professional soldier who had succeeded Banks as Commanding Officer of the Gulf Department, to issue an order revoking all appointments made by miltiary or semi-military officers in the state of Louisiana prior to March 4, 1865. The Governor had been forced to proceed that way because some office-holders contended that Gov. Wells was not clothed with the power to remove them from office. ${ }^{28}$ General Canby refused to comply with the Governor's demand, but added:

All officers who hold their offices by the tenure of military appointment are subject to military authority and control, and will not be permitted to interfere with in any manner whatever with the exercise of functions that have been committed to you as Governor of Louisiana. 29

Partially satisfied with the General's answer and assured of presidential support, Wells energetically pushed his removal policy, using the police when necessary. Even the arch-conservative creole paper, the New Orleans Bee, found that Governor Wells' direct and vigorous actions were scarcely accomplished "in a spirit of servile adherence to the usages and tradition of civil administration". Still, the Bee justified the "quasi-despotic attitude" of the governor on the grounds something had to be done and at once. 30

In the meantime, Thomas J. Durant, encouraged by Congress' refusal during the 1864-65 session. to admit the representatives and senators from Louisiana, began to forge a new political alliance of black and white radicals. 31 In order to achieve that goal, he had accepted honorary membership in the National Equal Rights League of Louisiana, a black political organization. ${ }^{32}$ By April and May 1865, a small circle of staunch radicals, under Durant's leadership, was building an organization to promote universal suffrage. 
The Universal Suffrage Movement held its first meeting on June 10, 1865 , in response to a call issued by Durant, Hornor, and Fernandez. It appears that the movement had two ultimate aims: to launch a strong party in favor of universal suffrage and to prevent the admission of the Louisiana delegation into Congress. The group held weekly meetings to strengthen its membership and to deal with current issues. The second of these meetings, on June 16, was especjally important; it was then that objectives and strategy were decided upon. The main event of the second meeting was the presentation of a far-sighted proposal by William R. Crane, a friend of Durant. Crane suggested the strategy that the radicals would adopt in the coming year: the radicals should first petition the state government for universal suffrage, and only after this demand had been rejected, devise some practical means to show the nation that "the colored vote should have beaten the copperhead candidates." Then, Crane detailed his views: "We must, first, demand the registration of all men legally; and then, if refused, let a voluntary registration be made. When the election for Governor takes place, let us have a candidate of our own, and see what the colored vote will be." The meeting concluded with the election of twenty-four members to a Central Executive Committee of the Friends of Universal Suffrage; Durant was made president. The committee was chosen without any distinction as to race or color and on the basis of six members, five legal voters and one black representative, for each of the four city districts. The Universal Suffrage Movement was launched. 33

In early July, 1865, Crane was beginnning to advocate the disfranchisement of the signers of the Ordinance of Secession, the supporters of the Confederacy, and rebel officers, while supporting suffrage and 
elegibility for offices for all other adult males. ${ }^{34}$ At the same time Durant was drafting, in accordance with Crane's resolutions of June 23, a petition for immediate universal registration in Louisiana. Durant was appointed by the Central Executive Committee to present it to Governor Wells, a task he performed on July 3. This memorial began with the assumption that "the rebellion has overthrown the Constitution and Civil Goverment of Louisiana, and rendered necessary the creation of a new State Government by the direct act of the people." But "the recent attempt here to re-establish government on a limited and imperfect suffrage is an admitted failure." Therefore, the petitioners asked Governor Wells to use the same discretionary porer by which he had "defined the qualifications of those who may be admitted to the registration of voters in New Orleans" to extend the elective franchise to all loyal citizens of the state, without distinction as to color or race. The memorial predicted that such an action:

Will make you forever loved and respected in Louisiana and throughout our country; it will ensure the tranquility of the State; it will establish the logical consequences of emancipation; it will put an end to the power of that aristocracy which organized the rebellion and still ambitiously aims at the power of the Government; it will neutralize and overpower the rebel elements which cannot be successfully excluded from the polls; it will speed our State on a new and unknown career of health and honor. 35

Wells not only refused to comply with the demand of the memorial, but published it, along with his written answer, in the New Orleans papers. In his reply, Wells opposed universal suffrage on the grounds that "from my knowledge of the negro character. . nine out of ten of the late entire slave population would support their former masters, personally or politically, or any way in preference to all strangers." 36 
Following Wells' negative answer, Durant forwarded the memorial to the President himself. Durant appealed to Johnson, "should [he] determine to exert any interference in Louisiana affairs, in advance of the action of Congress," to follow the recommendations of the memorial. 37 The President declined even to reply to Durant's letter. 38

While Wells was rejecting the proposal of the radicals, the BanksHahn faction which had lost the first round in its confrontation with the governor, did not abandon the fight. First it held a meeting at the Custom House to celebrate the 4 th of July. It then decided to send to Washington a series of petitions asking once more for the removal of Governor Wells and the appointment of a Provisional or Military Governor with the full power to complete the reorganization of the state by its loyal citizens. Finally, the Hahn-Banks faction used the visit of Carl Schurz, sent on a tour through the South by President Johnson, to vent their anger at Wells and his policies. ${ }^{40}$ Schurz's visit seemed an auspicious time to send Dostie to Washington to present the Free State party's case to government officials and to attack Wells and Kennedy. ${ }^{41}$ Hahn, Banks, Fish, and Shaw saw much of Schurz and tried to influence him on their behalf. ${ }^{42}$ Stanislas Wrotnowski, the secretary of state of Louisiana, and R. King Cutler and Michael Hahn, both United States senators-elect from Louisiana, wrote letters to General Schurz about the condition of affairs in Louisiana, letters which Schurz forwarded to the President. 43 But what the Banks-Hahn faction feared most and tried to prevent at any cost was the setting aside of the constitution of 1864 and the appointment of Governor Wells as Provisional Governor. ${ }^{44}$ The reason of their opposition was, as General Schurz reported, plain and simple: 
The transformation of the State Government of Louisiana into a Provisional Government would involve the setting aside of the Constitution of 1864, and if Gov Wells be made Provisional Governor, it will entrust him with the preparation necessary for the election of a convention and the making of a new Constitution. Having the vast machinery of the State Government with all its power and patronage in his hands--There are over two thousand civil officers in Louisiana, all selected and appointed by him--he will have a very great, perhaps decisive influence upon the result of the operation. 45

In fact President Johnson refused to appoint Wells provisional governor or to allow him to set aside the Constitution of 1864.46 Therefore, in accordance with the constitution, Wells called an election for November 6, 1865, by a proclamation of September 21, which recognized the validity of the 1864 constitution. The action antagonized the banking and business circles, since the 1864 constitution favored labor rather than the commercial interests. ${ }^{47}$ Moreover, it seems that "the pressure on him from Hahn, Cutler, Field, Hyams, and the thousand of other appointees whose places lay upon the adoption of the 64 swindle" was immense. 48 But, as the Picayune reported, Governor Wells "has not been able, nor has he, as we are aware, pretended, to do anything under the Constitution of 1864 , without the permission of the present military authority." 49 Wells had been left with but one choice: to call the election.

While the state was preparing for the election and political parties were taking form, adopting their platforms, and shaping their views about the different issues, Wells' policy of conciliation seemed to have succeeded marvelously in healing the wounds left by the war. The New Orleans papers, except for the Tribune, were defending him against Northern criticism. President Johnson was expressing confidence in him, and it seemed he would be the overwhelming choice for Governor at the election. 50 
By early September 1865, the Free State party and the old Planter party had disappeared and given way to four new parties. J.A. Rozier, rallying the old Democrats, formed the National Democratic party and called for a return to the 1852 Constitution, minus slavery. Meanwhile, the Old Whigs and Know-Nothings. coalesced around J.R. Conway, opposed the 1864 Constitution, and founded the Conservative Democratic party. Next, A.P. Field assumed the leadership of the most conservative portion of the Free State party, and created the Conservative Union party, which supported the 1864 Constitution but opposed universal suffrage. Finally a small group of radicals rallied around T.J. Durant in support of universal suffrage and a congressional Reconstruction and launched the National Republican party. By the end of the month each party was preparing for its state convention and adopting its strategy for the coming elections. 51

Meanwhile, after a summer of debate, the Central Executive Committee of the Universal Suffrage Movement translated Crane's original resolution into the concrete project of holding a Universal Suffrage state convention, to assemble on September 25. September 16 was set apart as election day for delegates to the convention; there would be six delegates, three whites and three blacks, for each of the eleven representative districts of the city, and six delegates for each country parish. Oscar J. Dunn, a former slave and a future lieutenant-governor of the state, was responsible for the organization of the election in New Orleans; this had to be conducted in accordance with the state electoral laws. Because of rumors spread "among the freedmen that registration was used to serve the US army, to enlist soldiers," Dunn at first had some difficulty with the task. 52 
The Tribune remarked on the day of the election that the members of the state convention would have important work to accomplish. They "will have to organize on a permanent basis, the great party of Universal Suffrage in Louisiana. They will shape the course of the party at the coming State election, and consider the propriety of sending a delegate to knock at the door of Congress." The paper noted also that the convention would be the first important deliberative body ever to assemble in Louisiana without distinction as to color or race and would be on a true fraternal footing, for the common defense of justice, freedom, and liberty. 53

More than 3000 people, whites and blacks, some of them workers who "had to leave their jobs from remote corners of the City" came to vote and elect delegates to the convention. As the Tribune reported, this first voluntary election demonstrated "that the disfranchised citizen can be safely trusted with the right of suffrage, without the slightest danger for the public peace. No election passed off more orderly and more quietly. $" 54$

Durant, as president of the Central Executive Committee, used the occasion of threats of violence made by the Southern Star to inform General E. R.S. Canby of the committee's intention of holding a convention as a first step "to appeal to the justice and intelligence of the representatives of the people in Congress to confirm the freedom of the colored race by extending the right of suffrage." Durant also told the general that he had "appointed agents to make a voluntary registration of the names and residences of the men of African descent so that at a future time they may designate by their votes one or more persons to go 
to Washington as delegates to support their views." To win Canby's support, Durant referred to the Star's editorial as "an allusion to and threat of assassination, or mob violence" and then asked the general "whether the discussion of the question of universal suffrage, and the course intended to be pursued by the Committee is anything else than innocent" or "is in any degree unlawful." 55 The general replied to Durant that after an examination of the subject, he had failed to find anything that was unlawful or "that militates against the peace and dignity of the United States." Since "the right of petition is a constitutional right" the petitioners would be protected "in the exercise of that right without distinction as to color. " ${ }^{56}$ Thus the convention could proceed to its work assured of the support and protection of the military authorities.

One hundred and eleven delegates assembled on September 25, 1865, at Economy Hall in New Orleans. In general, the delegates came from the business and professional community and represented the middle class whites and the upper class blacks (See Table III.1). As far as the white delegation was concerned, it tended, like the Free State party, to represent politicians who had been excluded from office or political influence before the war. Only four of the delegates had held office before the war, thirteen others only after the fall of New Orleans. However, the white Radicals differed slightly from the moderates as far as their role in the Civil War was concerned. Only nine of them--or 25 percent--out of a sample of 36 delegates had served in the Confederate army, while six--or 16.7 percent-had served in the Union army. But overall the Radical delegates did not differ greatly from the moderates. 


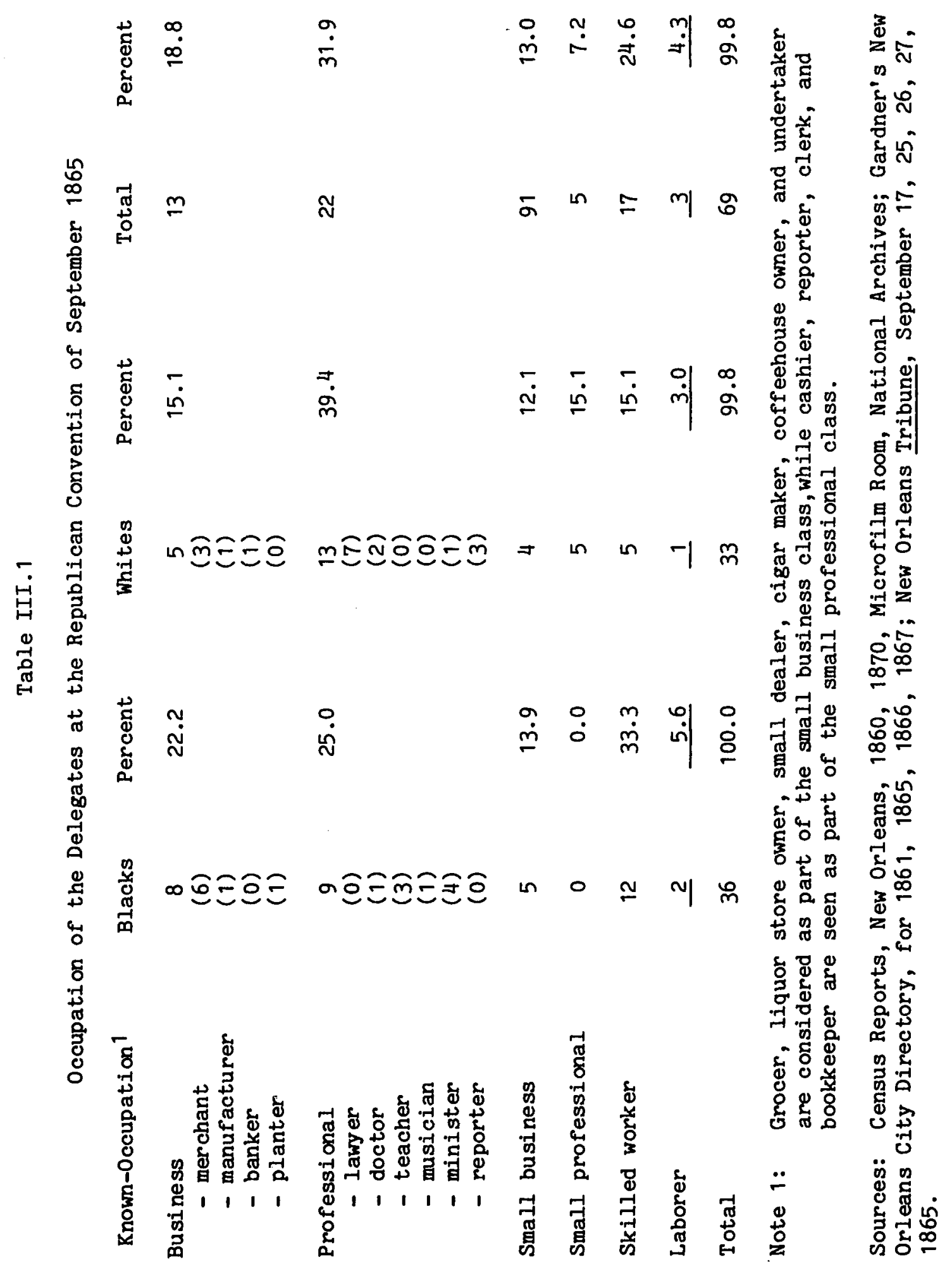


W.E.B. DuBois assumes that only 19 blacks--18 free blacks and 1 freedman--participated in the work of the Republican convention. ${ }^{57} \mathrm{~A}$ close study reveals that the black delegation was more than twice as large as DuBois' estimate. The Central Executive Committee had agreed before the convention election to a delegation equally divided between the two racial communities. 58 Therefore, New Orleans alone had at least 33 black delegates, since the city representation was fixed at 66. Of the 43 blacks that we identified, at least 33--or 78.6 percent--were free blacks before the war; a look at their occupation reveals an overwhelming predominance of upper class free blacks.

On the first day of its deliberations the convention unanimously elected Durant as its president. Thereafter, the convention divided on Warmoth's proposal that it adopt the principles and name of the National Republican party. Many Radicals objected to that step, seeing it as a halfway measure that would force the convention to follow the policy of the Northern Republicans and their party which had not yet given complete support to universal suffrage, but the National Republican label was finally adopted. The same session saw Warmoth offer twelve resolutions as the basis for the party platform. ${ }^{59}$ On September 27 the convention rejected a resolution critical of President Johnson. It then elected a Central Executive Committee, chose the Tribune as the official organ of the Republican party, and began to debate one of Warmoth's resolutions. Warmoth proposed that the convention proceed to the revision of the state constitution "to be submitted to the people for their ratificaton or rejection, at the next election, preparatory to the admission of Louisiana into the Union as a State." 60 The convention concluded its work on September 28 with the rejection of the Warmoth 
resolution on the drafting of a state constitution. The delegates decided that there was no time to spare for it, and that it would be illogical to "ask at once and the same time to be governed under the control of the General Government as a Territory, and to re-enter the Union as a State." Moreover, the convention voted to send but one delegate to the Congress to represent Louisiana as a Territory. Both Durant and Crane declined the nomination for this position; they said that they did not want any position of honor, profit, or emolument to be bestowed upon them, and that they could better serve the movement by remaining in Louisiana. The nomination was accorded to Warmoth, who accepted it with great pleasure. Finally, the convention adopted the final draft of a platform that advocated complete emancipation, and condemned any substitute for it in the form of serfdom or forced labor. It called upon Congress to extend complete civil, social, legal, and political equality to the black population, with universal suffrage as the cornerstone and the safeguard of that equality. 61

Following the adjournment of the convention, the new Republican party took immediate steps to ensure a large vote at the "voluntary" election of November $6,1865.62$ To achieve that effect, the party widely publicized its platform, especially among the freedmen; ensured a large registration by appointing in all the parishes where it was feasible registrars of voters; and, finally, held public meetings. The Tribune attempted to explain the meaning of the election. The Republican paper noted that while the Republican party did not present any candidate for state offices, it needed the votes of all those who were regularly registered; a large vote would serve as "the title by virtue 
of which the delegate will receive his credentials," which "title will be investigated by Congress." 63

On October 2 and 3, the National Democrats and the Conservative Democrats met together to choose a common ticket and adopt a common platform under the name of the National Democratic party. ${ }^{64}$ The significance of the Democratic convention came not from the platform or the ticket, but from the fact that for the first time it united under the same banner old Whigs and old Democrats. As Albert Voorhies, their candidate for the lieutenant-governorship, declared during the campaign, the convention made the Democratic party the white man's party, regrouping under the same leadership "without distinction of nationality and former political association--0ld Democrats, 0ld-time Whigs, KnowNothings, Bell-men, Douglas-Democrats, and Breckinridge-Democrats." 65 Moreover, Governor Wells in a letter to President Johnson and A.P. Field, the president of the Conservative Union party, in an address to a Union meeting before the election, declared that the new Democratic party was mainly composed of former Whigs and Know-Nothings. ${ }^{66}$ A close look at the political antecedents of the delegates at the convention, of the candidates, and of their supporters in the 1850 's reveals the predominance of Whigs and Know-Nothings in the 1865 Democratic party (See Table III.2).

On October 2 the Democratic convention was called to order by Dr. Riddell, who made the opening speech. Dr. Riddell told the delegates that the platform to be adopted and the ticket to be chosen had to reflect the conservative views of the Democratic party, though he also advised the delegates about the necessity of taking a moderate stand 


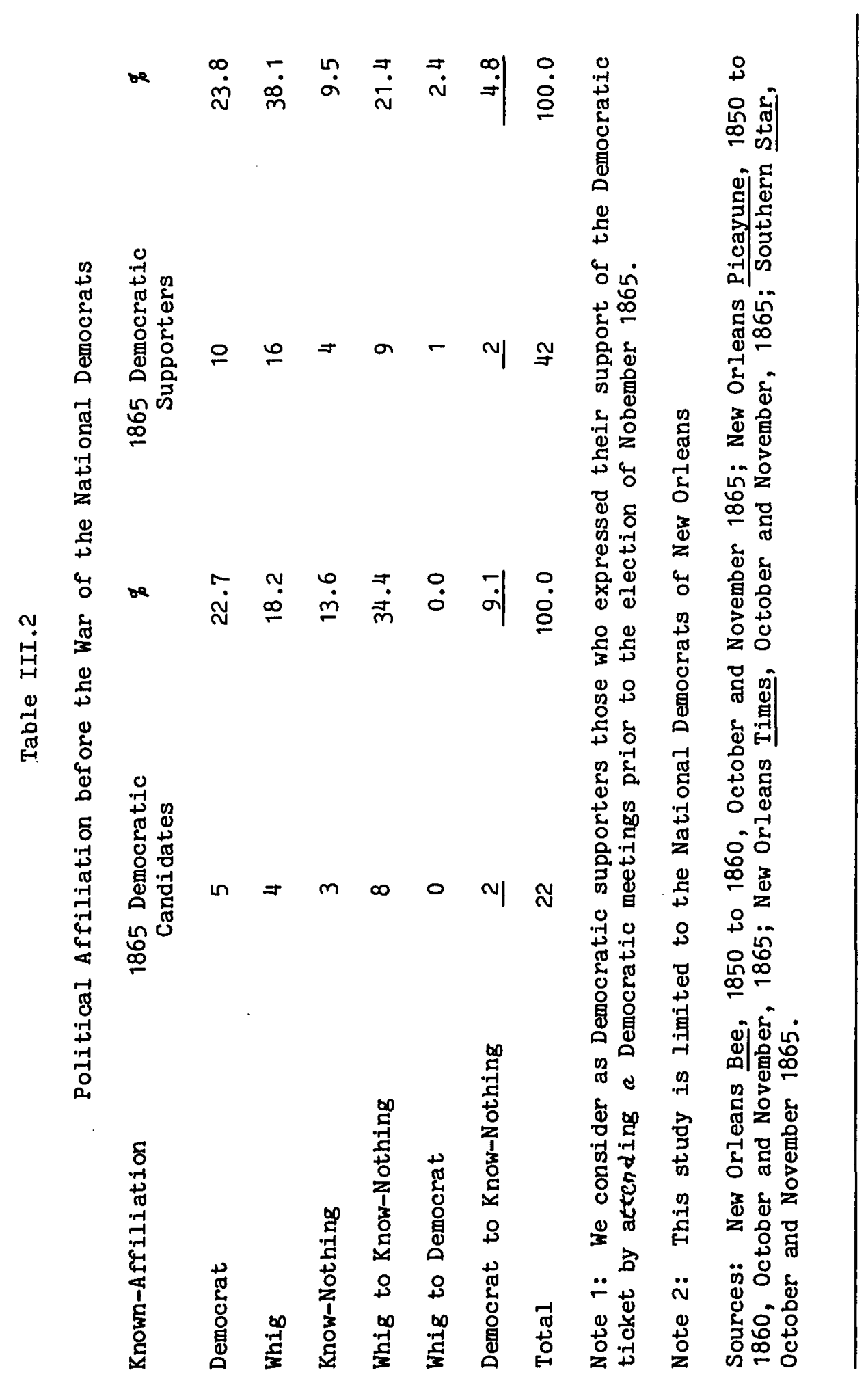


that would not conflict with Johnson's policy. But the convention was not ready to follow Riddell's advice. Resolutions were offered to ask the President to pardon Jefferson Davis, to expel a Mr. Shellery because he had been a "Black Republican", and to censure Dr. Riddell for having declared in his opening address that "secession. . was worse than a crime--it was a blunder."67 Finally, Albert Voorhies congratulated himself for having participated in the Rebellion. 68

The convention, however, declared its unqualified support for the national Demodatic party and the Johnson policy. The tone of the platform was throroughly conservative. It resolved that the government of Louisiana was one of white men, for the benefit of the white men. 69 It declared that since the 1864 Constitution was a fraud a state convention should be called to drawa new Constitution. Slaveholders should be compensated for emancipation, a general amnesty should be given and property fully restored, and, finally, all citizens should join the Democratic party in its opposition to the Radical Republican party. 70

Next the convention chose a ticket. The Executive nominees were drawn from the most conservative and "respectable" class of the state. The convention chose the Acting Governor J. Madison Wells as its candidate for the governorship; Albert Voorhies, son of a Justice of the state Supreme Court and himself a former member of that Court, as LieutenantGovernor; J.H. Hardy, brother of a former Secretary of State, as Secretary of State; Major A.S. Herron, former Secretary of State, as Attorney General; J.H. Peralta, a former State Auditor, as Auditor of Public Accounts; Adam Giffen, former New Orleans C1ty Treasurer, as Treasurer; and finally R.M. Lusher, former United States District Court Clerk and 
former Chairman of the Board of School Di rectors of New Orleans, as Superintendent of Public Education. 71 The main weakness of the Executive ticket was that, with the exception of Governor Wells, the nominees had all actively supported the Confederacy.

The Democratic Legislative ticket had the same quality and the same deficiency as the Executive ticket. The candidates chosen to represent New Orleans included the best names in the City. Among the Senate candidates, were Judge M.A. Foote, a brilliant young jurist, Judge Louis Duvigneaud, a well-known scholar and writer, John Finney, a former member of Judah P. Benjamin's law firm, and J.M. Lapeyre, president of the Louisiana State Bank. Nominees for the House, included such influential members of the New Orleans bar as James Phillips, Alfred Philipps, B.F. Jonas, James Eustis, J. McConnell, and C.A. Fenner; Thomas Murray, the architect who built the Mechanic's Institute; Charles J. Leeds, son of a wealthy business family; W. Alexander Gordon, a wealthy and distinguished merchant; Joseph Solomon, the well-known ex-Recorder of the Third District; P.S. Wiltz, an old state legislator and city administrator. Of the 48 city candidates for the legislature, there were 11 lawyers, 8 merchants, 7 clerks, 6 business men, 4 bankers or brokers, 1 doctor, 1 reporter, and 10 whose occupation is unknown. The Democratic party had become the party representing the interest of the commercial and professional community (See Table III.3). Of those 48 city candidates at least 17 had previously held public office. Although conservative, the Democratic ticket could be fairly described as one of the best ever presented to the city with respect to capacity, talents, and experience. Although a fairly large number of ex-rebels had joined the Democratic party, many of whose names appeared on the ticket (See Table III.4), 


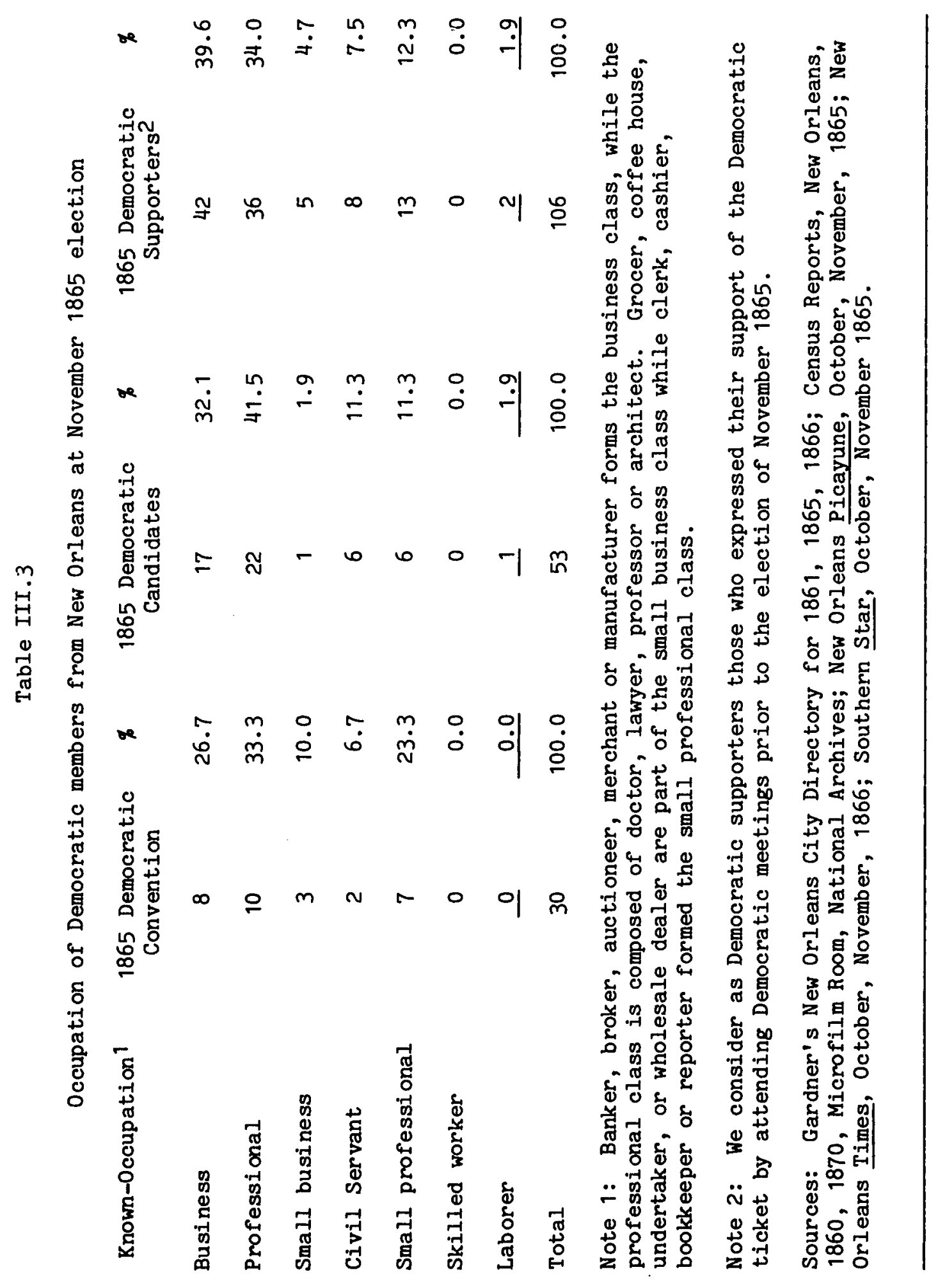




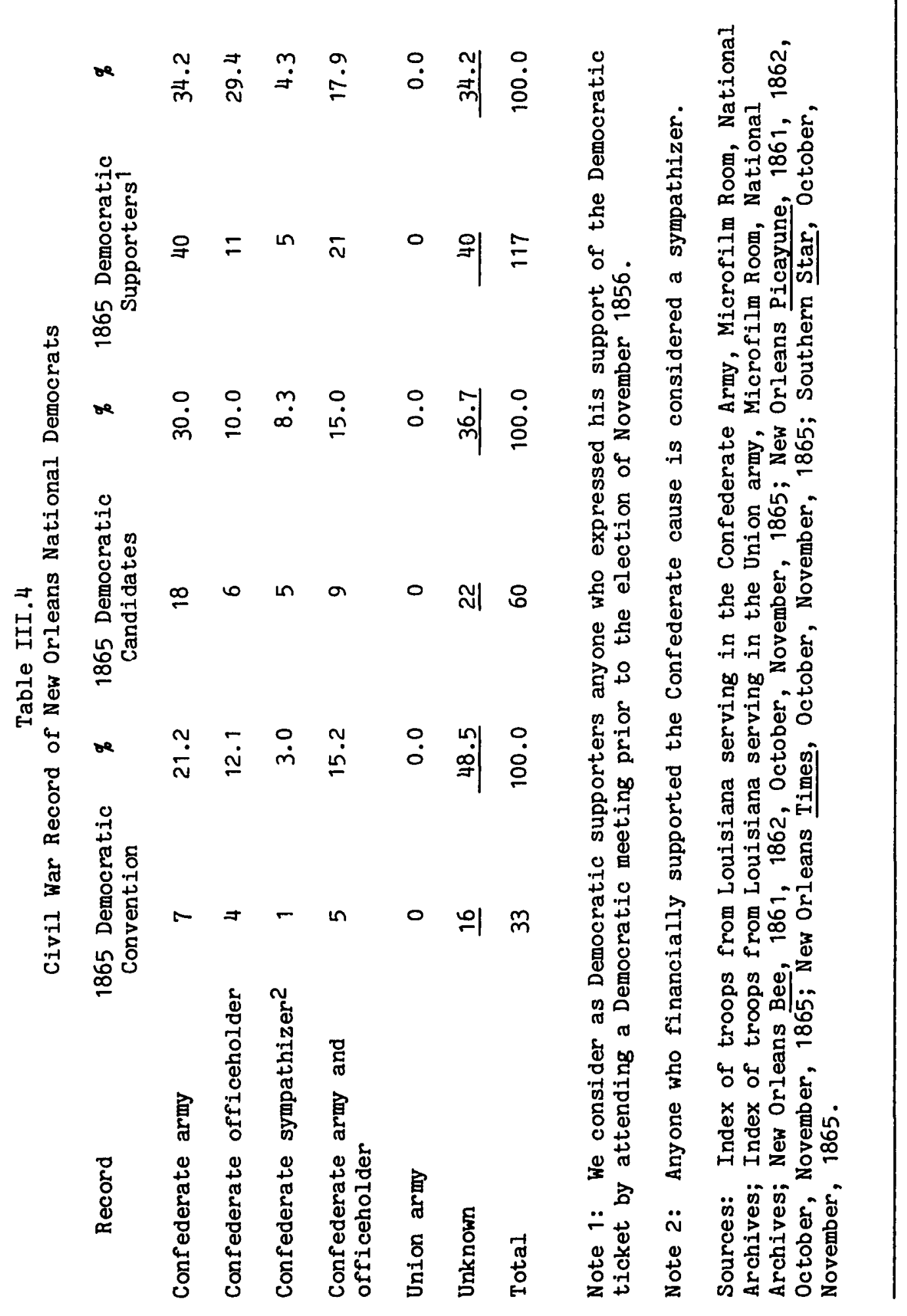


Governor Wells did not seem to be afraid of them. As he wrote President Johnson:

\begin{abstract}
Whatever may have been their antecedents, I regard them as true, sincere and loyal men, who have renewed their allegiance in good faith--who realize and accept the new order of things and will prove faithful to the Government and the trust reposed in them, if elected.72
\end{abstract}

Events would quickly demonstrate the governor's error. In October 1865, his political prospects seemed promising, as the Conservative Union party gathered to adopt its platform and to choose its ticket. In the Conservative convention, the Free State men were reunited; only their leaders had changed. Hahn, Cutler, Durrell, Dostie, and Howell had been replaced by A.P. Field, Dennis Cronan, and R.C. Richardson. ${ }^{72}$ Like the Free State party, the Conservative Union party drew its ticket from the middle class and looked for support to the small business and professional community and to the working class (See Table III.5). Although the percentage of ex-rebels in the Conservative Union party was as large as in the Democratic party, the conservatives avoided placing too many ex-Confederates on their ticket (See Table III.6). Moreover, the Conservative ticket differed from the Democratic one in that few of its candidates had played an active political role in the $1850 \mathrm{~s}$ or had held some office. ${ }^{74}$ Still, the Conservative convention was able to choose a respectable executive ticket.

The convention, by a vote of 117 to 30 , chose Governor Wells over Judge J.G. Taliaferro as its candidate for the governorship. The rest of the Conservative ticket was composed of Judge Tallaferro for Lieutenant-Governor, T.J. Edwards for Secretary of State, J.T. Michel for Treasurer, George S. Lacey for Attorney General, Valsain Founette 


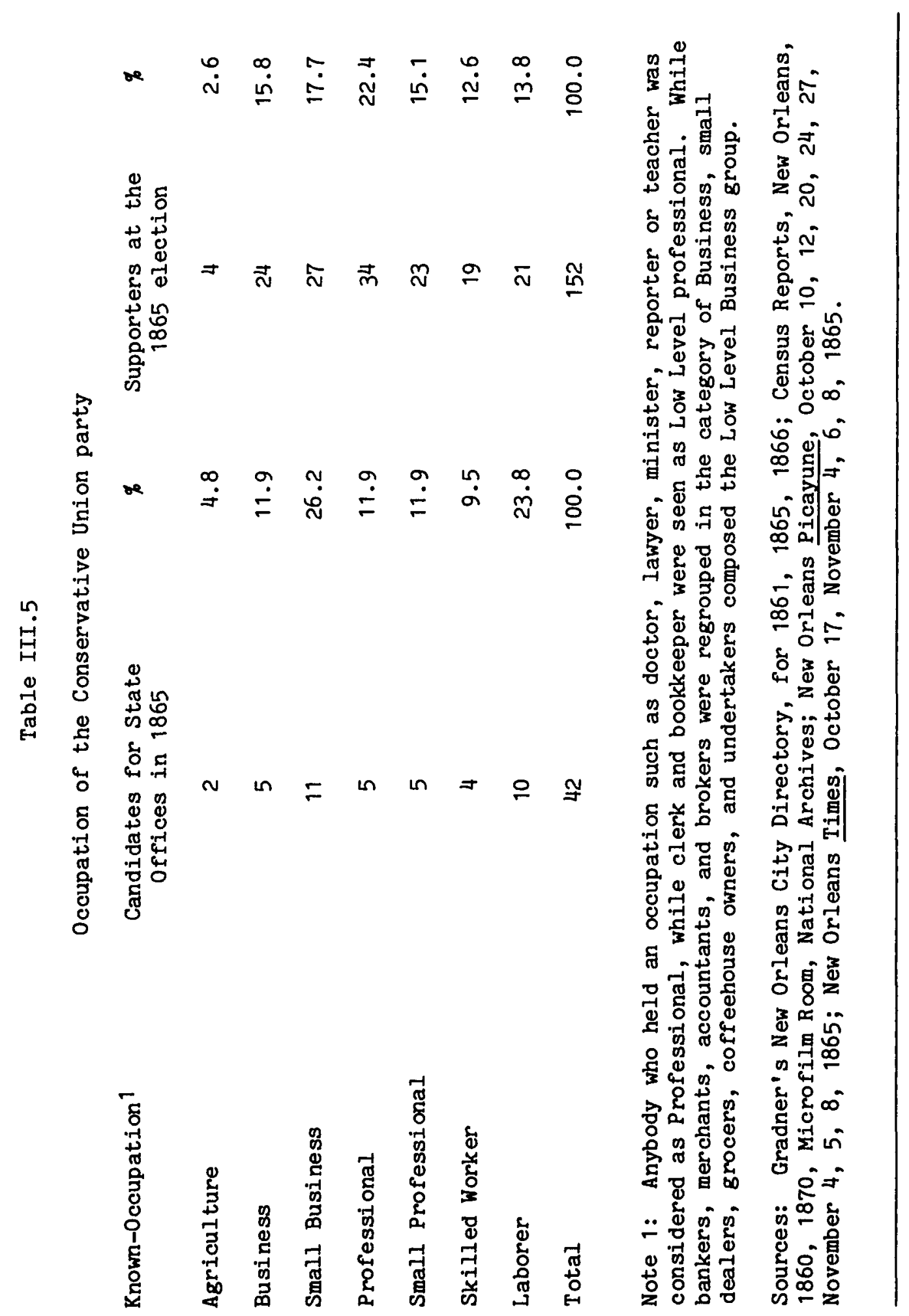




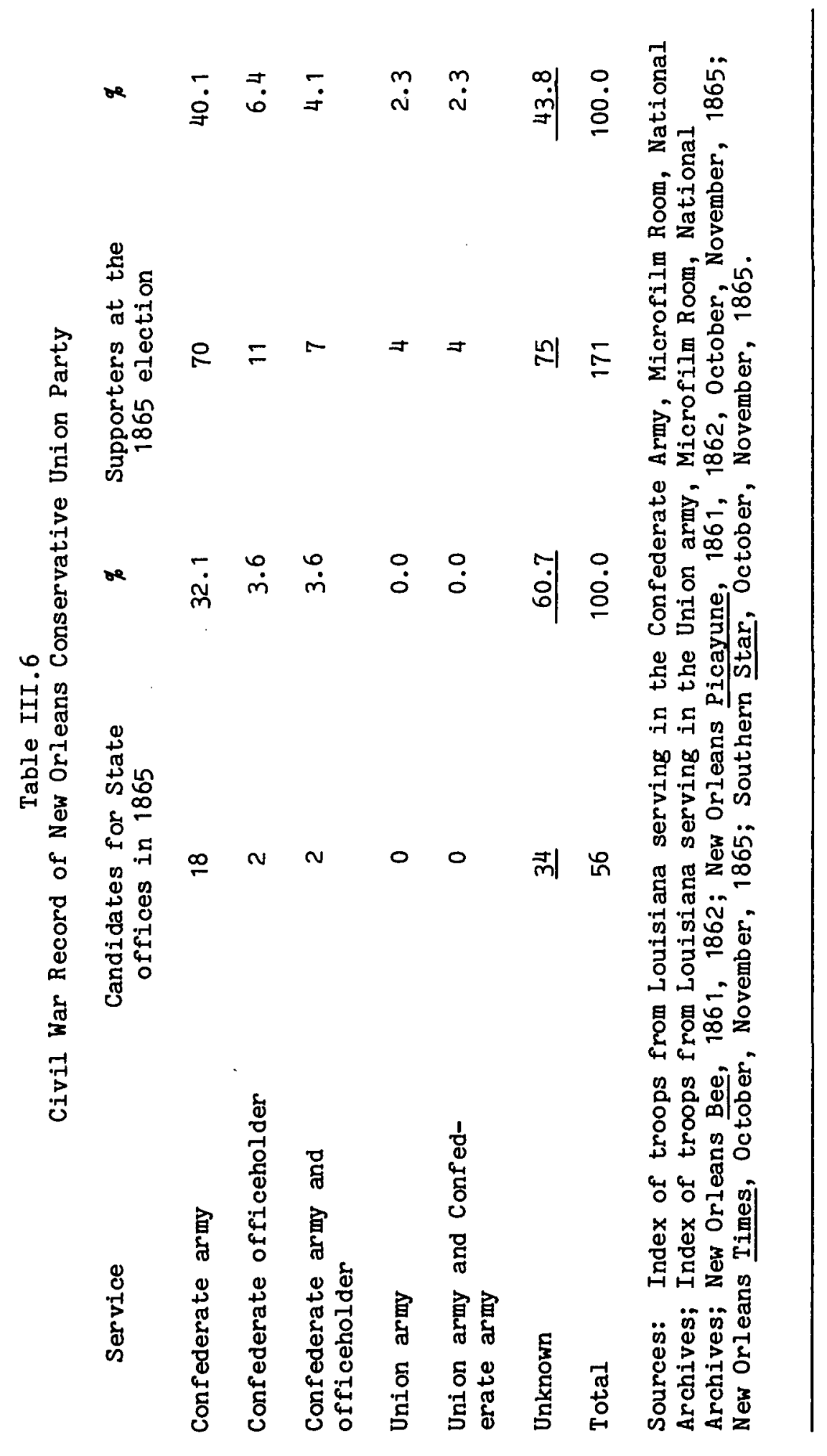


for Auditor of Public Accounts, and R.C. Richardson for Superintendent of Public Education. 75 Governor Wells, who had seen a growing challenge inside the Democratic party with the development of a movement to elect Henry $w$. Allen, the popular ex-Confederate governor of Louisiana, 75 was pleased and accepted the nomination gracefully.

Afer carefully reading the same, I am pleased to acknowledge the conservative character and conciliatory tone that pervades the platform. According to my understanding, there is no material difference in its principles and those adopted by another convention, whose nomination I have already accepted. Both platforms are in unison with principles, liberal measures and harmonized policy of the National Executive. 77

Since the new party was anxious not to be pictured as the "nigger party," the Conservative convention adopted a platform very similar to the Democratic one. It called for a speedy resumption of Louisiana's relations with the national government, acceptance without reserve of the United States constitution, support of Johnson's policy, opposition both to the "spread of radical principles and the elevation of the African upon a footing of political equality with the white man," the permanence of "the right of suffrage as now established by the Constitution of the State, restricting the elective franchise to the white race alone," the establishment of just labor laws, and a general amnesty. But the Conservative platform differed from the Democratic one in its support of the 1864 constitution and its strong oposition to the assumption of the Confederate State debt. ${ }^{78}$ This difference over the 1864 constitution would be the main issue between the Conservative and Democratic candidates thoughout the electoral campaign. 79

At first, it appeared that the election would be a contest between the Conservative Unionists and the Democrats, while James Madison Wells 
who headed both tickets, would be the overwhelming choice of the people. But soon after the Democratic Convention, Wells saw this happy prospect fade away. The governor, who had been the unanimous choice of the Democratic convention, discovered that it would be more difficult than he at first thought to keep the dissident element of that party under control. As H.M. Watterson wrote President Johnson, that Governor Wells "has to meet many difficult questions and encounter some factious opposition." 80 Watterson was referring not only to Durant's radical group but also to the growing movement in favor of Henry $W$. Allen. Although neither he nor his friends approved of the movement, some Democrats unhappy with the Democratic platform and ticket decided to launch a movement for Allen's election. Allen's candidacy was quickly seen by the entourage of Governor Wells as a real and serious danger, threatening to jeopardize all the governor had attempted to do during the previous eight months. 81

The Southern Star, Governor Wells' and Mayor Kennedy's paper, repeated again and again that Allen's candidacy was unacceptable to the North and that his election would prevent a speedy restoration of Louisiana to the Union, jeopardizing Johnson's policy. The Star was forced to acknowledge that Governor Wells was perhaps not the most popular candidate, argued he was the best man for the situation. Finally, the Democratic party asked prominent ex-Confederates such as General Harry T. Hays to sign a public appeal advising people not to vote for Allen but for Wells. The Allen candidacy seemed to become the issue as the electoral campaign drew to a close. 82

In fact, the threat represented by Allen's candidacy was believed to be so grave that President Johnson thought it necessary to intervene in 
the campaign in order to help Wells. Johnson decided to replace the Rev. Thomas W. Conway, Assistant Commissioner of the Freedmen's Bureau in Louisiana, who had antagonized not only a large segment of the white population but the President himself by his political radicalism and his support of universal suffrage. ${ }^{83}$ But the significance of the removal of Conway became clear only when the President ordered General J.S. Fullerton to Louisiana to take charge of the Freedmen's Bureau during the interim period before the crucial election and before General Absalom Baird, the new assistant commissioner, had arrived in New Orleans. Immediately after his arrival in Louisiana, General Fullerton attempted to influence the outcome of the voting. First, he published an address to the Freedmen of Louisiana advising them that he would enforce the anti-vagrancy law; second, he closed the Freedmen's Court opened by Conway at the end of September, judging that the state courts were sufficient for the present need; third, he restored a large part of the confiscated property to its owners, even to unpardoned ex-Confederates; finally, he abolished the school tax for Freedmen schools, which the whites had complained about. 84

Meanwhile the electoral contest came to an end. The campaign had been bitter; many candidates had set aside the discussion of the pending issues and assumed the unpleasant task of probing old sores. "With sincere regreat" wrote the Times, "we notice that a feeling of bitterness accompanied by criminative and recriminative assaults has become mixed up with the canvass in this City." 85 0ld political quarrels were revived and mixed with personal attacks. "This candidate is assailed because he was not a representative Confederate in Confederate 
lines; that one, because he was; this one, because he was too early in abandoning the sinking ship. . ..."86

On November 6, 1865, the people of Louisiana went to the polls and showed near unanimity in favor of the National Democracy. "The Democratic ticket, as might have been expected, swept all before it." 87 The governor and other Democratic candidates for state executive offices won a six to one majority; the five Democratic candidates for Congress a four to one majority; the six state senators representing New Orleans a five to one majority; and the 42 state representatives from the City of New Orleans a four to one majority. The threat represented by Governor Allen appeared to have been greatly exaggerated, and the bitterness of the campaign was soon forgotten. The result of the election was seen as an enthusiastic endorsement of the Wells-Johnson plan of Reconstruction. The Louisiana population now expected the lifting of martial law, the removal of the Freedmen's Bureau, and the admission of the state to the Union. 88

While the state was holding its regular election the Republican party of Louisiana simultaneously held its voluntary election with H.C. Warmoth as candidate for a seat in Congress as "territorial delegate". The election was a great success for the Republican party, although as Flanders wrote to Warmoth on November 23, 1865: "if there had been a little more exertion made to secure a larger colored vote, there is no doubt that you would have received twice the vote that Wells has. As it is your vote is nearly as large as his." 89 The Iribune stated that "the vote has been remarkably heavy in the civilized parishes, where lawful liberties were respected." 90 In fact, in the ten parishes 
where bureaus of registration had been opened, Warmoth received 19, 105 votes of which more than 9,000 came from New Orleans. Moreover it was calculated that around 2500 ballots were cast for Warmoth by registered voters at the regular polls. Secretary of State Wrotnowski certified that at the voluntary polls approximately 2500 whites, 1000 black soldiers born free, 5000 blacks born free, 2000 freedmen soldiers, and 8605 civilian freedmen had cast votes. 91

A Republican rally was held on November 13 to celebrate the election results. Although the meeting was attended not only by radicals but also by large numbers of the Hahn faction, the two speakers for the night were the radical Benjamin Flanders and Rufus Waples. Both were later strongly criticized by the conservative press for their "incendiary" speeches. Waples had charged that the majority of the population favored a republican form of government, but that "the temper of the unrepentant traitors renders good men apprehensive that they would, by violence, undertake to defeat the will of the majority." Flanders was accused of attempting to incite the recently emancipated freedmen with his statement:

\begin{abstract}
We hear it stated that the men of this party--they who are the advocates of equal rights--will yet be killed upon the streets-that it will be unsafe for them to hold their opinion. This threat has been held on that the Union men are to be killed [cries of never, never]. Now, some of us may fall. If we cannot discuss our principles without fear of assassination, we may know it. 92
\end{abstract}

The meeting concluded with the adoption of a series of resolutions in support of Warmoth, republican government, and recognition of Louisiana as a territory, and against Governor Wells and the Democratic 
party. 93 Following the meeting, the Southern Star expressed the hope that:

Some of the talkers at the assemblage will be taken in hand by the Grand Jury of the Parish of Orleans, in accordance with the charge of Judge Abell of the Criminal Court. As a matter of course we do not report the proceedings--no decent paper would do so. 94

In early November 1865, Governor Wells' political situation could scarcely have been better. His conciliatory policy toward the ex-Confederates seemed to be working beyond any expectations and he had just been overwhelmingly elected governor. The only thing left was to secure the full readmission of Louisiana to the Union, with the seating of its representatives in Congress. And yet, a close observer could have predicted that great difficulties lay ahead for the politics of conciliation. 
Notes for Chapter III

1 Wells to his wife, May 23, 1865, Wells Papers, Louisiana Historical Society Library (LHSL), New Orleans.

2Wells to Lincoln, March 6, 1865, Lincoln Papers, LC; Wells to Johnson, April 28, 1865, Johnson Papers, LC.

3 Debates in the House of Representatives of the State of Louisiana, Sessions of 1864-1865, March 4, 1865, 394-95.

${ }^{4}$ Schurz to Johnson, September 4, 10, 1865, Cutler to Schurz, September 5, 1865, Wells to Johnson, September 23, 1865, Johnson Papers, LC; See also G.M. Capers, Occupied City, 143; J.R. Ficklen, History of Reconstruction in Louisiana, presented a succinct view of the conciliatory policy of Governor Wells $(104-106)$; F.H. Harrington, Fighting Politician, commented that Wells as a planter, "could hardly fit into the Banks-Hahn party", since that party "drew much of its support from white laborers" (166-167); W.M. Lowrey, "The political Career of James Madison Wells", Louisiana Historical Quarterly, XXXI, (October, 1948) also presented a succinct view of Wells' conciliatory policy (1024-26).

$5 \mathrm{Dr}$. Hugh Kennedy had been from the 1850 s up to 1864 the owner and the conservative editor of the New Orleans True Delta. Kennedy had not only headed a vigilante group in 1858, but was in 1863 a leading member of the Planter's party which opposed Durant's convention project.

6 Wells to Hurlbut, March 17, 1865, letters received, Civil Affairs, RG 393, War Department; New Orleans Picayune, May 9, 1965.

7Hurlbut to Kennedy, March 22, 1865, letters sent, Civil Affairs, RG 393, War Department; New Orleans Picayune, May 9, 1865.

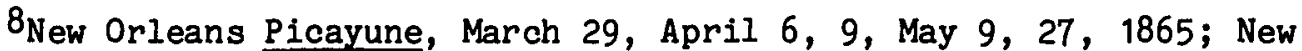
Orleans True Delta, April 11, May 2, 1865; See also G.M. Capers, Occupied City, 143.

9Julien Neville, the defeated conservative candidate for state auditor in February 1864, replaced Dostie as auditor; Charles Bienvenue, a member of the secession convention, succeeded Alfred Shaw as Sheriff for New Orleans; Aristide Bienvenue, a former Confederate office-holder, superseded W.R. Fish as Clerk of the Second District Court, C.W. Stauffer, an ex-Confederate soldier, supplanted J.R. Terry for the important office of Registrar of Voters, and the arch-conservative Edmund Abell replaced Ezra Hiestand as judge of the First District Court.

10 Fernandez to Johnson, May 7, 1865, Johnson Papers, LC; Denison to McCulloch, May 6, 1865, Denison Papers, LC; New Orleans Picayune, 
May 27, November 4, 1865; New Orleans Tribune, May 3, 4, 1865; See also F.H. Harrington, Fighting Politician, 167, 172, 173; W.M. Lowrey, "The political career of James Madison Wells," 1025, 1028, 1034, 1052; J.G. Taylor, Louisiana Reconstructed, 59

${ }^{11}$ New Orleans Picayune, May 27, 1865.

12New Orleans True Delta, March 31, 1865.

13Brook to Johnson, May 5, 1865, Johnson Papers, LC; New Orleans True Delta, June 4, 13, 1865.

${ }^{14}$ Warmoth diary, May 14, 1865, Warmoth Papers, UNCA.

15Warmoth diary, May 26, 1865, Warmoth Papers, UNCA.

${ }^{16}$ Dostie to Wells, April 21, 1865, Brook to Johnson, May 5, 1865, May to Schurz, May 6, 1865, Banks to Hooper, May 6, 1865, Banks to King, May 6, 1865, Banks to Ashley, May 6, 1865, Christie to Johnson, May 7, 1865, Fernandez to Johnson, May 7, 1865, Graham to Denison, May 10, 1865, Johnson Papers, LC; Denison to McCullock, May 6, 1865, Denison Papers, LC: See also W.M. Caskey, Secession and Restoration, 166-167; W.M. Lowrey, "The Political Career of James Madison Wells," 1029-31.

17A certain Paul McLean wrote to George Hardy on May 7,1865 , on the subject of the Smith-Brady investigation. McLean specified to Hardy that General Banks thought he had played a strong card in removing Dr. Kennedy: "I have appointed Col. Quincy, a scion of a noble house, who can command the support of Sumner, Andrews, Wilson \& this party. These secesh sympathizers Gov. Wells, Dr. Kennedy make war up on me because Col. Quincy is a Yankee, one of the old puritan stock and one of you. Gentlemen you must sustain me in this matter." See McLean to Hardy, May 7, 1865, New Orleans, Box 15, Smith-Brady Report, RG 94, War Department; see also Quincy to his mother, May 5, 10, 1865, Quincy Papers, Massachussetts Historical Society (MHS); Labor Petition, May 1865, Banks Papers, LC; New Orleans Times, May 5, 6, 7, 8, 9, 1865; New Orleans True Delta, May 5, 6, 7, 8, 9, 1865; W.M. Lowrey, "The Political Career of James Madison Wells," 1031.

${ }^{18}$ See Warmoth Diary, May $16,7,1865$, Warmoth Papers, UNCA; New Orleans Picayune, May 17, 18, 19, June 17, 18, 1865; New Orleans Times, May 14, 18, 19, June 18, 1865; New Orleans Tribune, June 1, 1865; New Orleans True Delta, May 18, 1865.

19 Wells to Johnson, April 28, 1865, Johnson Papers, LC.

20 Quincy to his mother, May 10, 1865, Quincy Papers, MHS.

21 Quincy to his mother, June 1, 5, 7, 1865, Quincy Papers, MHS; Wells to his wife, May 23, 1865, Wells Papers, LHSL.

22Wells to his wife, May 23, 1865, Wells Papers, LHSL; See also W.M. Lowrey, "The Political Career of James Madison Wells," 1032. 
23Cottman to Johnson, June 14, 1865, Johnson Papers, LC; Eric L. McKitrick, Andrew Johnson and Reconstruction (Chicago, 1960), 48-49.

${ }^{24}$ Wells to his wife, May 23, 1865, Wells Papers, LHSL.

$25 \mathrm{New}$ Orleans Picayune, June 10, 11, 12, 1865; New Orleans Times, June 11, 12, 1865; New Orleans True Delta, June 11, 1865.

26 Wells to Johnson, July 3, 1865, Johnson Papers, LC.

27Warmoth diary, June 16, 17, 1865, Warmoth Papers, UNCA; New Orleans Bee, June 18, 1865; New Orleans Picayune, June 18, 1865; New Orleans Times, June 18, 1856; New Orleans Tribune, June 17, 18, 1865; See also W.M. Lowrey, "The Political Career of James Madison Wells," 1035-36; Senate Exec. Docs., 39 Cong., 1 sess., No 2, "Report of Carl Schurz," 12, 67, 68 .

28 "Report of Carl Schurz", Documents, Wells to Canby, June 10, 1865,54 .

29 But this did not resolve all problems between military and civil authorities. During the months of July, August, and September, 1865, Dr. Kennedy complained regularly of military interference in purely civil affairs. The mayor saw the military authority overruling his decisions on questions of prisoners in the workhouse, the repairing of the city wharves, appointment of a school board, and police regulations concerning black meetings. Kennedy accused Canby of military despotism and collusion with the Hahn-Banks faction, and asked repeatedly for his removal. See "Report of Carl Schurz," Documents, Canby to Wells, June 19,1865 , 55; See on Kennedy-Canby controversy, Johnson Papers, in July, August, September, 1865.

${ }^{30}$ New Orleans Bee, June 15, 1865; See also New Orleans True welta, June 25, 1865.

31 The House Judiciary Committee drew a report in favor of the admission of the Louisiana Free State delegation, but Congress adjourned without taking any decision on the case.

32New Orleans Tribune, January 15, 19, 1865.

33"Proceedings of the Convention of the Republican Party of Louisiana, held at Economy Hall, New Orleans, September 25, 1865," see report on June $10,16,1865$, this pamphlet can be found in Library of Congress; J.C. Houzeau, "Le Journal No1r," 98-99; New Orleans Tribune, June 17, 18, 1865; P.D. Uzee, "The Beginnings of the Louisiana Republican Party," Louisiana History, XII, (Summer 1977), 205.

${ }^{34}$ New Orleans Tribune, July 7, 1865.

35 New Orleans Times, July 12, 1865; New Orleans Picayune, July 12, 1865; New Orleans True Delta, July 12; 1865; New Orleans Tribune, July 12 , 13, 1865; W.M. Caskey, Secession and Restoration, 170-71. 


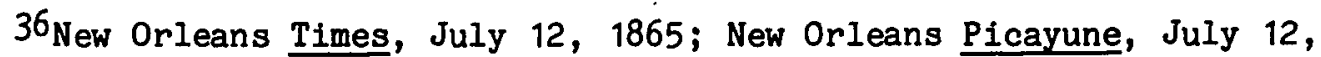
1865; New Orleans True Delta, July 12, 1865; New Orleans Tribune, July 12 , 13, 1865; W.M. Caskey, Secession and Restoration, 170-71.

37Durant to Johnson, July 13, 1865, Johnson Papers, LC.

${ }^{38}$ Durant to Warmoth, February 14, 1866, Warmoth Papers, UNCA.

39 Hire to Covode, July 12, 1865, Petition to Andrew Johnson, July, 1865, Cottman to Johnson, July 20, 1865, Johnson Papers, LC; New Orleans Tribune, July 6, 1865; F.H. Harrington, Fighting Politician, 169.

${ }^{40}$ See Johnson Papers, Letters of Schurz to Johnson, July, August, September, 1865.

${ }^{41}$ Banks to Maynard, September 5, 1865, Kennedy to Johnson, September 10, 1865, Johnson Papers, LC.

${ }^{42}$ Cottman to Johnson, September 9, 1865, Kennedy to Johnson, September 10, 1865, Johnson Papers, LC.

43Cutler to Schurz, September 5, 1865, Hahn to Schurz, September 6, 1865, Wrotnowski to Schurz, September 7, 1865, Johnson Papers, LC.

${ }^{44}$ Schurz to Johnson, September 4, 15, 23, 1865, Johnson Papers, LC; See also Telegram of Major General Carl Schurz to President Johnson, September 5, 1865, series 2, Microfilm 40, Johnson Papers.

${ }^{45}$ Schurz to Johnson, September 23, 1865, Johnson Papers, LC.

46 on August 19, 1865, Johnson sent a telegram to Wells asking him "what number of persons who are active and prominently desire the appointment of a Provisional Governor?" A month later on September 18, 1865, Johnson telegraphed again to Wells stating that he had been very inclined to name a Provisional Governor but still hold it in suspense and asked Wells to proceed promptly and without delay or hindrance on the work of reorganization. However, Johnson assured Wells of his support, if any conflict occurred with the military. See Telegram of Johnson to Wells, August 19, September 18, 1865, Microfilm 40, series 2; see also in Johnson Papers, Cottman to Johnson, June 14, July 20, 1865, Kennedy to Johnson, July 21, 1865; for New Orleans press see, New Orleans Bee, June 15, 17, August 31, September 14, 1865; New Orleans Picayune, June, August 19, 30, September 10, 21, 24, 29, 1865; New Orleans Times, June 15, July 13, 1865; Southern Star, September 3, 8, 1865 .

47Schurz to Johnson, September 23, 1865, Spoffard to Rozier, September 26, 1865, Johnson Papers, LC; New Orleans Picayune, September 24, 29, 1865; J.G. Taylor, Louisiana Reconstructed, 71.

48 Spoffard to Rozier, September 26, 1865, Johnson Papers, LC.

49 New Orleans Picayune, September 21, 1865. 


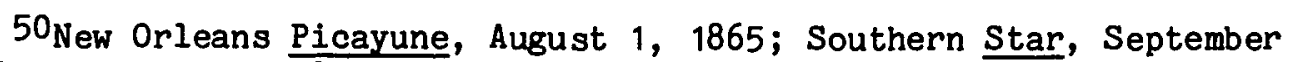
$3,8,29$, October 18,1865 .

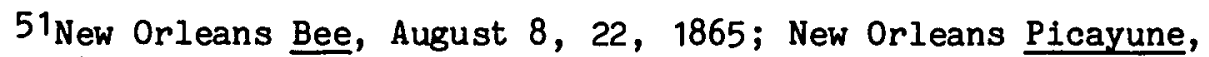
August 8, 22, September 1, 22, 1865; J.G. Taylor, Louisiana Reconstructed, 71,72 .

52New Orleans Tribune, August 4, 23, 29, September 8, 13, 1865.

53New Orleans Tribune, September 16, 1865.

${ }^{54} \mathrm{New}$ Orleans Tribune, September 16, 19, 1865; see also J.C. Houz eau, "Le Journal Noir." 99.

55Durant to Canby, September 21, 1865, RG 393, M 1738, Gulf Department, War Department; see also Southern Star, September 17, 1865; New Orleans Tribune, September 24, 1865.

${ }^{56}$ Canby to Durant, September 26, 1865, letters sent, RG 393, Gulf Deartment, War Department.

57W.E.B. DuBois, Black Reconstruction, 462

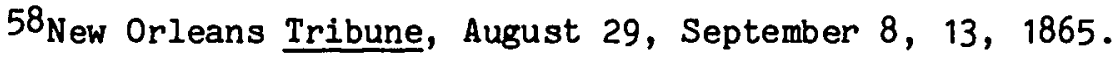

59 Warmoth diary, September 25, 1865, Warmoth Papers, UNCA; see also J.R. Ficklen, History of Reconstruction in Louisiana, 112-13; P.D. Uzee, "The Beginnings of the Louisiana Republican Party," 205-6; J.G. Taylor, Louisiana Reconstructed, 76; New Orleans Tribune, September 26, 27, 1865; "Proceedings of the Republican Convention of Louisiana," September 26, 27, 1865.

60 New Orleans Tribune, September 28, 1865.

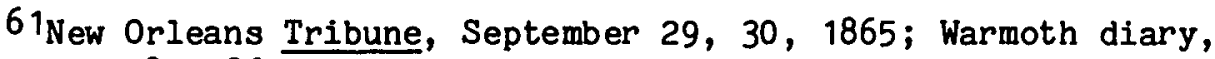
September 28, 1865, Warmoth Papers, UNCA; J.C. Houz eau, "Le Journal Noir," 100-101; J.R. Ficklen, History of Reconstruction in Louisiana, 113; P.D. Uzee, "The Beginnings of the Louisiana Republican Party," 205-6; J.G. Taylor, Louisiana Reconstructed, 76 .

62 The name "voluntary election" was used by the radicals to distinguish it from the regular election. Both elections were to be held on November 6; but the voluntary differed from the regular one in that blacks were allowed to vote. Moreover, the radicals did not present any ticket for state offices, only a candidate to represent Louisiana as a Territory in Congress.

63 New Orleans Tribune, October 1, 1865.

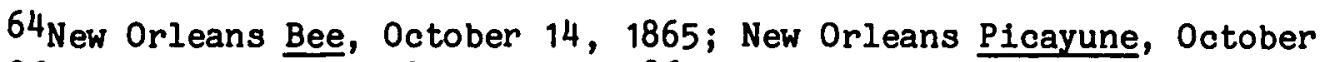
3, 1865; Southern Star, October 3, 1865.

65 Southern Star, November 6, 1865. 
66 New Orleans Picayune, November 5, 1865.

$67 \mathrm{Dr}$. Riddell was forced by the convention to apologize in the newpapers for his remarks and he died heartbroken, a few days later. See New Orleans Picayune, October 3, 1865; Southern Star, October 3, 1865; J.G. Taylor, Louisiana Reconstructed, 72.

68 Warmoth diary, October 3, 1865, Warmoth Papers UNCA; New Orleans Picayune, October 3, 4, 1865; New Orleans Times, October 3, 4, 1864; Southern Star, October 3, 4, 1865.

69 That the Democratic convention did not show any open-mindedness about the question of suffrage is quite obvious; and yet it scarcely acted worse than the Conservative Union convention or the Northern. Radicals. On October 19, 1865, in an exasperated tone, the New Orleans Bee commented about the inconsistency of Northern radical who asked for Negro suffrage in the South but refused it in their own State: "Why should Louisiana adopt it when Connecticut had just voted to perpetuate the exclusion of the negroes from the ballot box, and in the Ohio when the negroes have not political right and when the people have just elected a governor opposed to negro suffrage."

$70 \mathrm{~A}$ copy of the Democratic platform was printed frequently in the major city papers; See New Orleans Bee, October 1865; New Orleans Picayune, October 1865; New Orleans Times, October 1865; See also New York Times, October 5, 1865; W.M. Caskey, Secession and Restoration, 174-75; J.R. Ficklen, History of the Reconstruction in Louisiana, 109; W.M. Lowrey, "The Political Career of James Madison Wells," 1056; J.G. Taylor, Louisiana Reconstructed, 72.

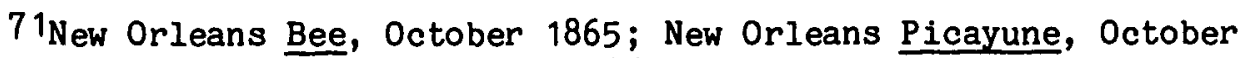
1865; New Orleans Times, October 1865; See also New York Times, October 5, 1865; W.M. Caskey, Secession and Restoration, 174-75; J.R. Ficklen, History of the Reconstruction in Louisiana, 109; W.M. Lowrey, "The Political Career of James Madison Wells," 1056; J.G. Taylor, Louisiana Reconstructed, 72.

72 Wells to Johnson, October 6, 1865, Johnson Papers, LC.

73 New Orleans Picayune, September 12, October 10, 1865; See also W.M. Caskey, Secession and Restoration, 175.

74 At least 17 Democratic party candidates had either held a city or a state office during the $1850 \mathrm{~s}$, while the Conservative Union party had only 4. And yet the Conservative party had 21 of ? candidates who held an office under the Union during the War.

75 New Orleans Picayune, October 12, 1865; W.M. Caskey, Secession and Restoration, 176-77; J.R. Ficklen, History of Reconstruction in Loulsiana, 111; Surprisingly, J.G. Taylor, Loulsiana Reconstructed, did not mention the role played by the conservative Union party in the election of November 1865. 
76 Watterson to Johnson, October 14, 1865, Johnson Papers, LC; Southern Star, October 12, 18, 21, 28, November 1, 3, 4, 1865; W.M. Caskey, Secession and Restoration, 176; W.M. Lowery, "The Political Career of James Madison Wells," 1058, 1060.

77 Southern Star, October 13, 1865.

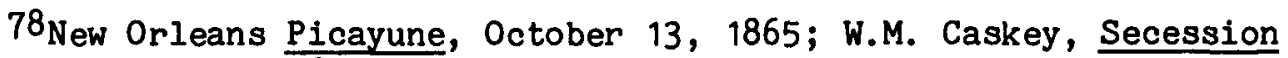
and Restoration, 176-77; J.R. Ficklen, History of Reconstruction in Louisiana, 111; W.M. Lowrey, "The Political Career of James Madison Wells," 1058-60.

79 New Orleans Picayune, October 15, 17, November 5, 1865; New Orleans Bee, October 16, November 3, 1865; W.M. Caskey, Secession and Restoration, 176-77.

80 Watterson to Johnson, October 14, 1865, Johnson Papers, LC.

81 W.M. Lowrey, "The Political Career of James Madison Wells," $1058-60$.

82 Southern Star, October 12, 18, 21, 28, November 1, 3, 4, 1865; See also New Orleans Bee, New Orleans Picayune, New Orleans Times, October 1865; and W.M. Caskey, Secession and Restoration, 176-77.

83House Exec., Docs., 39 Congress, 1 session, No. 70, "Report of General 0.0. Howard", 393; The best account on the removal of Conway is found in W.S. McFeely, Yankee Stepfather, General 0.0. Howard and the Freedmen, (New York, Norton, 1968) 173-79; see also H.A. White, The Freedmen's Bureau in Louisiana, (Baton Rouge, 1970) 19-21.

84"Report of General 0.0. Howard," 393-403; Fullerton "Address to the Freedmen of Louisiana" October 20, 1865, Circular no 22, October 25, 1865, Circular no 24, October 30, 1865, Circular no 27, November 2, 1865, in Scrapbook of Order and Circular received and issued, in Freedmen Bureau, RG 105; see also Fullerton to Canby, November 1, 1865, letters recelved, Freedmen Bureau, RG 105; New Orleans Bee, October 19, 21, 1865; New Orleans Times, October 21, 1865; The best account on the role played by General J.S. Fullerton in the November 1865 Louisiana election is W.S. McFeely, Yankee Stepfather, 173-179; see also H.A. White, The Freedmen's Bureau in Louisiana, 22-24, and C. Peter Ripley Slaves and Freedmen in Civil War Louisiana, 187-8, 204-5.

$85 \mathrm{New}$ Orleans Times, November 2, 1865.

86 Ibid.

87 Southern Star, November 7, 1865.

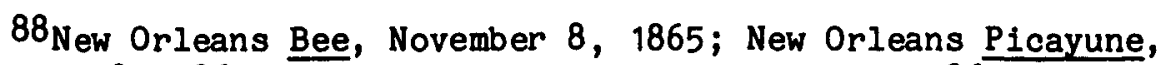
November 8,1865 ; $\overline{N e w}$ Orleans Times, November 12, 1865; New Orleans Tribune, November 7, 1865; Southern Star, November 8, 1865.

${ }^{89}$ Flanders to Warmoth, November 23, 1865, Warmoth Papers UNCA. 


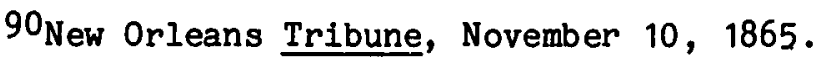

91 Warmoth diary, November 6, 18, 1865, Warmoth Papers, UNCA; National Republican, December 4, 1865; New Orleans Bee, December 20, 1865; New Orleans Tribune, November 15, December 19, 1865; W.M. Caskey, Secession and Restoration, 181.

92New Orleans Bee, November 16, 1865; New Orleans Times, November 14, 15, 16, 1865; New Orleans Tribune, November 14, 15, 16, 1865; Southern Star, November 14, 1865; W.M. Caskey, Secession and Restoration, 181-184.

93Warmoth diary, November 6, 18, 1865, Warmoth Papers, UNCA; National Republican, December 4, 1865; New Orleans Bee, December 20, 1865; New Orleans Tribune, November 15, December 19, 1865; W.M. Caskey, Secession and Restoration, 181.

${ }^{94}$ Southern Star, November 14, 1865. 
CHAPTER IV

The Democratic Ascendancy

Until the election of November 1865, Governor Wells' conciliatory policy proved to be very successful, and then in the month following the election it collapsed like a house of cards. In early December, Wells' message to the legislature involved him in a bitter fight with the Democratic assembly. An embittered Wells shifted from a very conservative to a very radical policy. By the spring of 1866 , he not only encouraged Warmoth in his project of holding a radical state convention, but he also began discretely to induce the members of the late 1864 convention to re-assemble.

After the November election Governor Wells seemed less ready to pursue his policy of concilation and accomôdation. Wells discovered that he would now have to hold in check a state legislature dominated by ex-Confederates. The campaign and the election results led the governor to think that it would be more difficult than he had previously believed to keep the Democratic party under his control. Besides the Allen movement, Wells' fears had been aroused by a group of ex-Confederates whom the governor, in an unusual step, had personally commended to the President as deserving pardon and who were now fomenting opposition to the governor's policy. 1 One sign of the change in Wells' attitude, as Kennedy reported, was his request to Johnson, in November 1865 , that a Negro regiment be quartered in each of the parishes that had given a majority to Allen. ${ }^{2}$ 
Following the election, the governor decided to call a special session of the new legislature for November 23, 1865. Wells wanted the legislature to elect senators to replace Hahn and Cutler when Congress met in December, take action to repair the levees in order to prevent destructive inundations, and restore the state's oredit. ${ }^{3}$ Before the legislature convened, such questions as calling a new constitutional convention, instituting a new labor code, creating a new banking system, and calling a city election began to stir up public opinion and were discussed at length by the press. 4

The legislature assembled in the hall of the Mechanics' Institute in New Orleans on November 23, 1865. Since only one half of the membership was present, Governor Wells waited until November 29 to allow the delegates of the northern part of the state to make their journey to New Orleans before he delivered his message to the assembly. By then the city delegation was already working as a unit and using its power to override the rural delegates. ${ }^{5}$ The legislature had embarked upon "the uncertain and dangerous era of general and experimental legislation." 6 Bills had been presented to amend the city charter, to remodel the courts, to protect creditors, to regulate labor, and to call a constitutional convention. 7

On November 29, the governor delivered his message. The choice of United State senators, the question of the state debt, and the need to repair the levees formed the cornerstone of his message. But the governor also called the attention of the legislature to the question of labor, suggesting that each laborer should have as much as possible control over his own affairs and the right to contract with whomever he 
chose. The governor also pointed out the need to appropriate money to encourage immigration. Finally, the governor concluded his message by pointing out the danger of secret associations. ${ }^{8}$ The message of Governor Wells was direct, straightforward, and free from party spirit. But the message was also important for what it did not say. It did not mention the calling of a convention, nor did it ask the legislature to amend the city charter of New Orleans or to call a city election.

At the beginning of the session, the governor and the legislature quickly fell out over minor points. First, the legislature antagonized Wells by choosing as its official journal the New Orleans Crescent of J.0. Nixon, a former leading Know-Nothing, rather than the Southern Star, the official journal of the state in which the governor and the mayor had heavily invested. ${ }^{9}$ Second, Wells offended the legislature by postpolng his own inauguration at the last minute because of personal indisposition without fixing any future date for it, which was seen by many legislators as a great lack of consideration on the part of the governor. ${ }^{10}$ However, the major differences were precipitated by the governor's message. Disputes over the existence of "secret societies", the election of United States senators, labor legislation, city elections, and the tax collection bill brought a complete rupture between the legislative and the executive branch as early as December 1865.

The legislature got particularly angry about Wells' allusion to "secret societies;" it asked him to be more specific. The governor refused to comply with the assembly's request on the grounds that by so doing "the ends of public justice would be defeated;" but the governor again asked the assembly to pass a law giving him the power to deal with 
that question. ${ }^{11}$ The legislature not only refused to pass such a law, but threatened to impeach him if he persisted in his refusal to give a satisfactory answer to its request. ${ }^{12}$ From numerous sources, it appears that Wells' anxiety over the question of secret associations was based on real foundations, but behind that question lay a fight for offices. ${ }^{13}$ This incident shows that the breach which had already appeared inside the Democratic party prior to the election was deeper than it seemed at first glance.

As for electing new senators, the legislature quickly followed Wells' suggestion. It agreed that Michael Hahn and R. King Cutler should be replaced, but differences arose about the choice of their successors. The governor had emphasized that the legislature had the power to deal with that question, since Hahn and Cutler had been elected by a legislature which did not represent the whole state. However, some members of the legislature argued that such a step would be unconstitutional, and that only after a constitutional convention could new senators be elected. The legislature finally followed the governor's suggestion and proceeded to an election. During the debates over who should represent the state, an attempt was made to get rid of Wells by electing him to one of the seats. Lieutenant-Governor Voorhies would then have become governor. Angered by this maneuver, Wells made it clear that he would refuse the nomination. Then the legislature chose two prominent exConfederates, Henry Boyce and Randall Hunt, as the United States Senators for Louisiana. 14

The next question debated by the assembly was whether or not a constitutional convention should be called. By the fall of 1865, the 1864 
constitution had drawn opposition from all quarters and support only from a handful of unionists. The Democratic legislature had been elected on the promise of getting rid of that constitution. Conservatives argued that a new convention was needed because the existing constitution had been framed by fraud and by only a part of the state, and because the United States Congress refused to recognize its legality. There were other justifications for a new convention such as a judiaiary which needed both remolding and new appointments, a city delegation which was too powerful in the assembly, and the need to replace Hahn and Cutler, the two unseated United States Senators elected by the preceding legislature. But finally, the basic question was whether a state government should be organized by the people for themselves, or created by others and imposed upon them without their participation or consent. ${ }^{15}$ Those who opposed the call of a new convention contended that article 147 of the constitution furnished a way to make all the necessary changes without the calling of a new convention. They argued that a new constitution would have lesser standing before a radical Congress and hence would delay the state's readmission; furthermore it would cost from $\$ 200,000$ to $\$ 300,000$, a large burden for an empty treasury. Finally, they contended that President Johnson supported the 1864 constitution and a change would undercut his policy. ${ }^{16}$

The first ten days of the session were completely overshadowed by the convention question. Subjected to strong pressure from the governor to set it aside, ${ }^{17}$ the legislature was divided on the issue. Finally, despairing of success and afraid of undermining the President's policy for a smooth restoration of Louisiana to the Union, the assembly moved to postpone the question to the next session. ${ }^{18}$ But the debate was far from over. 19 
The city delegates, defeated on the convention issue, then forced a debate over the call for a city election. The supporters of this idea justified it on the grounds that Federal authorities needed to be relieved of the burden of supervising the municipal corporation, and that the actual condition of affairs compelled the present military city administration to do many things which should be done by civil officials elected by and responsible to the people. ${ }^{20}$ But the move for a city election was really a fight for power and offices, a subtle attempt to undercut the power of the governor by getting rid of Mayor Kennedy. ${ }^{21}$

The followers of Governor Wells and Dr. Kennedy saw a need for a new charter. However, they opposed the idea of an early city election, which would have deprived Wells of his control over the city administration, since "those who were the author of our national calamities" were likely to win the contest. Two thousand offices were at stake and the governor's faction was particularly concerned about the role that the police force of the city, as then organized, could play in the political arena. $^{22}$

Although a few city delegates defended Wells' position, a bill was introduced to call a city election. It seemed to have the approval of a majority of the legislature, but failed to pass because Wells opposed it. 23 The question was postponed until the next session.

The next matter to be debated by the legislature was a new labor code. By the fall of 1865 , the white population of Louisiana felt an urgent need for a new system that would replace slavery while ensuring white control of black workers. ${ }^{24}$ The planters had suffered severely from the drastic reduction of sugar and cotton production since 1860 , 
and they felt threatened by large-scale black vagrancy and by the "unfortunate teaching" of white radicals. They also resented the presence of the Freedmen's Bureau as an encroachment upon the state's jurisdiction. $^{25}$ They favored a new system of labor which would bring the black population back to the plantations. As R.P. Constantin observed in "The Louisiana 'Black Code' Legislation of 1865", the question of securing an adequate labor force was for the planter an acute one. This "was not just a question of whether he could wait until the freedmen settled down; but whether he could survive the waiting bankruptcy and foreclosure." 26 The legislature was especially sensitive to the feeling and problems of the planters and white population in general over that issue. 27

The conservative press cynically exploited white fear of black competition in order to prevent white and black workers from making a common front to defend their rights. The papers argued that all whites--workers, merchants, businessmen, shipowners, and planters--had an interest in the military measures that prevented plantation workers from flocking into the city. If those orders were suspended as many as 50,000 blacks would pour into the city and, through competition, bring considerable reduction in the wages of white workers. In every way, they argued, it would be in their interest for the white workers to support the measures advanced by the leading men of the community and to oppose racijal equality and universal suffrage. ${ }^{28}$ The appeal worked; racism and fear of black competition proved stronger than any common economic interests. White workers, who had previously aligned with the Free State party, massively supported the Democratic party at the November 1865 election. 29 
The Democratic legislature elected in November 1865 represented mainly the old order and was largely composed of ex-Confederates. Elected on a white supremacy ticket, it approached the need for a new labor system less as a way to reduce the blacks to slavery than as a means of social control and as a way to prevent the black population from becoming a burden on the community. 30 Moreover, the Democrats thought that Johnson's plan of Reconstruction would prevail and that a new labor code would be needed to replace the Freedmen's Bureau. They argued that new labor contracts had to be concluded for the coming year and regulations passed for their enforcement. Furthermore, they said, the existing system based on competition was unfair to the blacks. ${ }^{31}$ Thus the "black codes" that the legislature ultimately passed are important as a statement of white expectations with respect to Reconstruction.

On November 24, Duncan F. Kenner, a state senator, wealthy sugar planter, and former Confederate Congressman, introduced several resolutions dealing with the labor question. ${ }^{32}$ As chairman of the select joint committee, he played a vital part in getting several bills through the legislature. ${ }^{33}$ The first compelled the planters to furnish the same clothes, food, and medical attention to hired vagrants as they did for their other workers. The second provided punishment for whoever harbored, helped, or incited laborers, vagrants, or servants to escape. The third provided punishment for employers who hired laborers already under contract or who discharged a laborer without cause before the end of his contract. The fourth and last act defined the status of the freedmen and regulated labor contracts. 34

The three first bills became law as Governor Wells signed them on December 20 and 21, 1865. But the last one, the cornerstone of the 
Louisiana Black Codes, never became law. Wells refused to sign it in order to "avoid conflict of interest between Louisiana Civil Law and Freedmen Bureau's regulations." 35 As a matter of fact, on December 18, General Absalom Baird, the new assistant commissioner for the Freedmen's Bureau, had asked the governor for his views on the recent labor bills. The governor answered the general on December 20:

I had already determined in my own mind that the action of the Legislature was not only impracticable, but unnecessary. I consider the existing laws as sufficient in defining the rights and status of the Freemen and in conjunction with the just and liberal rules and regulations you have recently promulgated. I cannot recognize the expediency of further legislation in the matter. I shall therefore withhold my signature in the case of the acts referred to. 36

Consequently, Wells pocket-vetoed the bill on the freedmen's status. Most of the New Orleans press supported the new legislation and praised the assembly for having passed such just and humane laws, without distinction as to race or color. It had, the papers wrote, avoided the short-sighted and selfish policy of Alabama and Mississippi, which had rushed into extremes by reviving the old servile institution. $37 \mathrm{By}$ contrast, Louisiana radicals strongly opposed the labor code, and Charles J. Dalloz wrote a series of three articles in the New Orleans Tribune attacking the unjust and inhumane side of the new labor code. ${ }^{38}$ Meanwhile in Washington, Hahn and Shaw joined H.C. Warmoth, Louisiana's "territorial delegate" in discrediting the Louisiana labor code and in arousing the Northern press against it. 39

In a final clash between governor and legislature, Wells vetoed a bill to suspend the collection of taxes for the years 1861, 1862, 1863, and 1864. This measure, said its backers, would mean "that the people 
of the country parishes should not be called upon to pay again the taxes they had been obliged to hand over to collectors under confederate rule." 40 However, Governor Wells refused to sign a bill that saw differently the situation he considered discriminated in favor of ex-rebels "at the expense of the loyal men of a portion of Southern Louisiana" on whom "the entire burden of sustaining the State and Local administration for merely four years had been thrown." 41 However, the governor's veto message drew a strong objection from the New Orleans Crescent, the Know-Nothing paper that had become the official paper of the legislature. The Crescent rejected the governor's objections as prejudiced and assumed that they originated from other sources, such as Dr. Kennedy: "But we find ourselves totally unable to pass over this attack upon the character of our people. It is so ungenerous, so undeserved, so unnecessary, that we can scarcely believe the Governor to have been incited to it by the promptings of his own mind or his own heart. " 42

The legislature adjoumed until the regular session, which would begin on January 23, 1866. It had sat for 25 days and had accomplished nothing. Its labor code was either vetoed by the governor or nullified by the General Order No. 29, on December 4, 1865, issued by General Baird, assistant commissioner of the Freedmen's Bureau. Its senatorselect did not even think a trip to Washington worth the expense. The urgent business of repairing the wharves and restoring the credit of the state had been set aside, while the state judiciary, the state militia, the country parishes, and the city of New Orleans had not yet been reorganized in accordance with the constitution of 1864. Finally, no 
constitutional convention had been called, nor had amendments to the 1864 constitution been proposed. Everything was left to be attempted again. 43

Trouble with the governor accounts in large part. for the legislature's undoing. But the legislature was also guilty of having launched experimental and unwise legislation, rather than implementing the recommendations of the governor. The New Orleans Crescent aside, all the city papers agreed that the legislature wasted its precious time discussing whether or not it should call a constitutional convention or a city election, the pet schemes of the city members, who were interested only in legislation dealing with offices. 44 In fact, the question of offices was the main cause of the break between the legislature and the governor, the single most important event of the extra session. As the legislature could be satisfied with nothing short of complete victory and total control of offices and patronage, the rupture between the governor and the assembly degenerated quickly into a deadly fight for power and control of offices. 45

By the end of 1865 , Governor Wells was in the peculiar situation of being attacked from every side and seeing his conciliatory policy shattered.

There are men, nevertheless, as the public are fully aware, who make charges against him; who do say, on one side, that no loyal man experiences his friendships; and, on the other, that no rebel is favored or countenanced by him. The first call upon the President to remove him; the second plot, censure, defame and intrigue to diminish and destroy him upon [sic] the popular affection. 46

To the radicals, both in the North and in Louisiana, he was a tool of the rebels at a time when the "rebels" wanted to get rid of him. 
Extremes had met in their hate of the governor and in opposition to his goal of "reconciling the people to the Government and Government to the people." 47 The governor had refused to give his complete endorsement to any clique, faction, or party whatsoever, only to discover at the end that all of them opposed his policy.

Henry $C$. Warmoth, who had been elected by white and black radicals as a "territorial delegate" in early November 1865, would play during the winter of 1866 an important role in discrediting the conciliatory policy of Governor Wells and Johnson's restoration of Louisiana. On November 18, Warmoth left for Washington to beseech Congress to admit him as a delegate from the Territory of Louisiana. He took with him not only his credentials, but a long petition signed by hundreds of people asking Congress to refuse Louisiana admission as a state and to establish a preliminary system of government "founded on the theory of equal political privileges before the law for all men without distinction of race, and that the military force of the United States be in no case withdrawn for the present." 48 Accompanied by Governor Hahn and Alfred Shaw, Warmoth called on Thaddeus Stevens, Edward McPherson, and others. Following those interviews, Warmoth reported in his diary that "old Thad says I am the only man who will be admitted from the Southern States. So do all the Radical Republicans." 49

Although Warmoth was never seated in Congress, he played an important role in the strategy of the Louisiana radicals. He kept Congress "daily advertised [sic] of the outrages and injuries frequently committed on loyal men, white and black." ${ }^{50}$ By sending Warmoth the Tribune and other New Orleans papers, as well as personal letters, Louisiana 
radicals publicized all incidents of violence occurring in the state. As Durant wrote to Warmoth, "these acts of terrible violence" should alert Congress to the true "temper of the people to whom the usurpation of the President confides exclusively the Governments of their States." These acts, Durant believed, were "better calculated to arrest the attention of a majority of members of Congress than any arguments founded on justice and the true law of political progress constructed from equality of rights." 51 However, Durant began in early January 1866 to express doubts as to the effectiveness of the radical strategy in sending a delegate to Washington.

By the end of January 1866, while Warmoth was expressing great confidence in the will and capacity of Congress to pass a radical Reconstruction program, Durant was becoming increasingly disappointed with Congress' handling of the suffrage question. On January 20 he worried that after Congress had passed the suffrage bill for the District of Columbia, "these virtuous defectionists will find themselves too much exhausted from the effort, to do anything more." Durant emphasized that "simply to refuse admission to Senators and Representatives from insurrectionary States, will not be enough. Inaction cannot be enough, we must have something done." The apparent unwillingness of the Republican party to deal with the real issue of suffrage brought Durant to conclude that the sooner the Republican party could be broken up, the better it would be for the country. On January 29, Durant informed Warmoth again of his apprehension that Congress would not pass a reconstruction bill with universal suffrage. Three days later he complained of the inaction of Congress and expressed his fears to Warmoth that Congress would leave suffrage decisions to the states. Durant also told Warmoth that the 
money advanced to him by the committee would run out by the end of the month, and that present financial conditions made it impossible to support Warmoth in Washington any longer. 52

Warmoth was of another opinion. He told Durant he believed that Congress was going to pass a constitutional amendment which would "base representation in Congress on the number of voters in each State." Durant, however, thought such a measure unwise. It would be accepted by the Southern states because they would have full representation in the Senate and would therefore be able to block an amendment securing universal suffage. Durant insisted that the only way to put the cause of republican government upon a firm and permanent base was "to have a reconstruction bill with equal and general suffrage, providing territorial government to last about 10 years, and a military bill such as Wilson's." 53 On March 2 Durant sent Warmoth final instructions: as neither the President nor Congress intended to enfranchise the blacks, the Central Executive Committee had decided "that your prolonged presence in Washington could be of no further service." 54

Even before Warmoth left for Washington, moderates expressed a desire to forget past differences and work with the radicals. The large number of Hahn faction members attending the Republican meeting of November 13,1865 , indicated that to some degree a process of radicalization was taking place among the moderates. There was a radical tone also in a series of complaints about conditions in Louisiana forwarded by many moderates to Banks and Warmoth in the late fall of 1865 . They reported that threats were daily and openly made against them, and they feared that former Confederates would persecute Union men once federal 
soldiers had been withdrawn. They complained that General Canby favored ex-rebels on all occasions and that trouble would result; they lamented that politics was at a standstill, and the only struggle was to avoid becoming involved with any particular party trend. 55 C.W. Stauffer, a former conservative member of the 1864 convention, described this growing radicalism. when he wrote to Warmoth in December 1865; he thought the universal suffrage movement was gaining ground in Louisiana and that from what he heard and saw "Union men are becoming more harmonized. $" 56$

On January 27,1866 , an attempt was made to unite the different unionist factions. Flanders, Dostie, and Field, the president of the conservative Union party, were the three main speakers at this gathering. Alhough many radicals were present and Flanders was elected chairman of the meeting, the proceedings were dominated by the Hahn people, represented mainly by R. King Cutler, United States senator-elect, R.W. Taliaferro, G.A. Fosdick, Julian Neville, W.H. Hire, M.F. Bonzano, W.T. Stocker, Edward Hart, and Terrance Cook. Dr. Hire and Dr. Dostie emphasized the need for Union men to forget past differences and to unite in resistence to the hostile plotting of the rebels who surrounded them. 57 Following the meeting, it was announced that Dostie and Field had joined the radical party, and many others were only waiting upon Congress' actions to do the same. 58

In addition, Warmoth collaborated closely in Washington with Hahn and Banks. 59 Such cooperation was desired by some important officials of the federal administration, as demonstrated by a letter to Flanders from William P. Mellen, former supervising special agent for the 
Treasury Department at Memphis. Mellen asked Flanders to promote an accord between radicals and moderates that would result in a state convention, where the black population would have some representation and which would amend the current state constitution. 60 But an alliance never materialized. For one thing, Durant was opposed to it, ${ }^{61}$ and for another, the ideological gap between the two factions remained too great.

During the winter of 1886 , most of the members of the Hahn faction continued to be more interested in disfranchising (which also disqualified them from holding office) the rebels than in enfranchising the blacks. 62 Although by Novemeber 1865, Michael Hahn had become an open advocate of universal suffrage, regularly attending the meetings of the Universal Suffrage Association in Washington, ${ }^{63}$ the majority of his faction was slow to follow his lead. John Henderson, Jr., a former member of the 1864 convention, later killed in the riot of July 30, 1866, wrote to Banks in December 1865, telling of his impression that "the loyal voters of the South are not yet prepared for political equality of the negro with the white man." Reiterating the common apprehension that with the right to vote would also come the right to hold office, Henderson asked Banks if "the people of the free States would select a black President over a white one? Would they be right if they did so?" And, Henderson inquired, "if the negroes are permitted to vote and hold offices, why not extend this right to the Indians?". For Henderson, the best way to secure tranquility in the South was not by granting suffrage to the blacks, but by refusing "to allow the Southern people back into the Union until they are faithful to the United States Government,"64 Writing in the same vein, Simeon Belden, a former senator in the Free 
State Legislature of 1864-1865, told Warmoth that although he shared with him the same devotion to the federal government, he was "not prepared to think it wisdom to invest the recently emancipated colored people indiscriminately with the right of suffrage," and that he would accept it only if "the people of the United States decided the universal rights of all men to suffrage." 65 Bernard Soulie, a free black radical, opposed the uniting of radicals and moderates because of the material differences which yet separated them. Commenting on the meeting of January 27 , he wrote to Warmoth that the participation of Colonel Field in that rally was "calculated to inspire distrust to all true lovers of universal liberty and equality." Soulie went on the express his pain at having seen Flanders figure in that "hybrid conclave." 66

The reassembling of the legislature toward the end of January proved to be another blow to any hopes for a political consensus in Louisiana. Two familiar questions dominated the debates: the calling of a constitutional convention and the passing of a city election bill. Over these two questions, Governor Wells and the legislature would clash once more. The session would show that the rupture with the governor, which was already evident during the previous session, was a complete and permanent one.

On the second day of the session the convention question was introduced. Many members acknowledged that during recent weeks they had found their constituents to be unanimously in favor of a convention. That assertion was not denied by their opponents, who simply argued that a convention was impossible as long a military authority and martial law 
were paramount. 67 Meanwhile the question continued to be debated extensively in the city press. ${ }^{68}$

Sensitive to the political struggle between President Johnson and Congress, early in February the legislature decided that before it took a decisive step toward a convention, it would send a committee to Washington in order to get the views of the President. The question was postponed until May 10, $1866 .^{69}$ The joint committee, composed of W.B. Egan, J.B. Eustis, and Duncan S. Cage, the speaker of the House, arrived in Washington near the end of February. In the course of several interviews the President convinced the committee of the necessity of dropping the idea of a convention al together. 70

Although the legislature was forced to drop the convention question, it was not completely defeated. The committee learned from the President that he opposed a new convention because, in accordance with his proclamation of May 29, 1865, he considered the 1864 constitution to be the fundamental law of the state, and that was the main reason why he did not appoint a Provisional governor for Louisiana in 1865. He could not change this policy now without jeopardizing his plan of reconstruction. ${ }^{71}$ But more important, the committee was able to cultivate a close relationship with the President at a time when the governor was losing the latter's confidence and support. The importance of this fact would become apparent in the debate over a city election.

At the beginning of the session, the legislature passed a bill calling for a city election on March 12, 1866, for Mayor, Common Council, and other officers of the municipal government of New Orleans. The second election was to be held on May 7, for the offices of Sheriff, 
Clerk of the Court, Justice of the Peace, and Constable for the parish of New Orleans and other parishes of the states. This speedy act of the legislature caused great excitement in the city. "The Johnny rebels are in great glee in anticipation of having the City Hall, cleaned out of all those whose sympathies and assistance have been given to the U.S. Government." 72 As former state senator Simeon Belden reported to Warmoth, the act showed how far the legislature and the governor were at odds, and how the control of the city of New Orleans had become the central issue. 73

Meanwhile, the governor asked the President his views and presented his own objections to the bill. Such an election, argued Wells, should be held no earlier than the time fixed by the city charter, the second Monday of June, and it should not be held at all if the city charter was not amended, because the influence of the newly elected officers would be sufficiently powerful to postpone indefinitely any amendment. ${ }^{74}$ But the main objection of the governor, as C.W. Stauffer recalled, was that the governor had "become fully convinced that the late returned rebels can not be trusted with power in their hands: and he was afraid that a city election would give. them control of the city administration. 75

One of the main objections of Wells to a city election was removed by early February 1866, when the legislature passed a bill amending the city charter. ButThis change did not satisfy the governor. Except for the support of the city officers, the governor stood alone against the express desire of the President, ${ }^{76}$ the commanding general of the Department, the overwhelming majority of the legislature, and the almost 
unanimous voice of the whole people, ${ }^{77}$ by vetoing both the city election and the city charter bills. ${ }^{78}$

The governor vetoed both bills on the grounds that the city election bill did not provide the necessary time required by 1 aw, ${ }^{79}$ and the city charter bill violated article 119 of the constitution, which specified that no bill could be passed in violation of an article of the constitution. The city charter bill, by calling for an election in March and fixing the term of office for those elected at two years and three months, violated the constitution, which specified that election of the city officers would take place in June, and that the officers elected should serve for two years. ${ }^{80}$ Therefore, the governor maintained that he could not in good conscience sign the bills, since they were unconstitutional and the present officers could refuse to vacate their offices and could bring their case into court. 81

But the legislature was not convinced by the governor's objections and unanimously overrode his veto on both bills. ${ }^{82}$ The legislature repassed both bills, with only eight who opposed the first and boycotted the second. 83 The governor, having lost the contest and the President's support was forced to direct the city administration to hold elections. 84

Two parties entered the contest: the National Democratic party supported by the legislature, and the Conservative Union party, supported by Governor Wells, Sheriff Bienvenu, Mayor Kennedy, and old members of the Free State party. ${ }^{85}$ As in November 1865 the same two parties opposed each other, with only one major change; the governor having passed to the Conservative Union party. The Democratic ticket 
was composed mainly of the old Know-Nothing office-holders of 1860 , running again for the same offices. The Conservative party drew its ticket largely from that part of the Free State party which had been Democratic before the war. ${ }^{86}$ Moreover, the Democratic candidates tended to have greater administrative experience than the Conservative ticket (See Table IV.1). Finally, there was a slight difference on the record of the candidates of each party during the war; the Democratic ticket had more candidates who had supported the Confederacy (See Table IV.2). But the two parties had, as the New Orleans Tribune reported, one thing in common; they were not formed of men of principle, but of office-hunters. 87

The electoral campaign did not proceed without incident. In order to influence the outcome, voters were intimidated, secret societies were formed on both sides, and police power used; one result of this was the political assassination of a man three days before the election. ${ }^{88}$ Moreover, the city administration also attepted to buy votes by hiring additional labor for public works, spending $\$ 26,000$ in the 15 days before the election when the usual amount spent per month was $\$ 15,000$. $^{89}$

On election day, the city voters had to choose 31 officers from among 68 candidates. The Democratic party won 21 offices, and the Conservative party 10 in a very close contest. Compared to the November 1865 state election, the March 1866 election showed a marked revival of the Union party. 90

The Conservative Union party did not accept its defeats easily. Protests were made, and a petition signed by 300 citizens was presented 
Table IV.1

Occupation of March 1866 city candidates

$\begin{array}{lcccc}\text { Known-Occupation } 1 & \begin{array}{c}\text { Democratic } \\ \text { candidates }\end{array} & \% & \begin{array}{c}\text { Conservative } \\ \text { candidates }\end{array} & \% \\ \text { Business } & 12 & 37.5 & 4 & 13.3 \\ \text { Professional } & 10 & 32.0 & 5 & 16.7 \\ \text { Small business } & 3 & 9.4 & 5 & 16.7 \\ \text { Low level Professional } & 5 & 15.6 & 8 & 26.7 \\ \text { Skilled Worker } & 2 & 6.3 & 6 & 20.0 \\ \text { Laborer } & 0 & 0.0 & \underline{2} & 6.7 \\ \text { Total } & 32 & 100.8 & 30 & 100.1\end{array}$

Note 1: Anybody who held such occupation as doctor, lawyer, minister, reporter or teacher was considered as professional, while clerk and bookkeeper were seen as Low Level professional. While bankers, merchants, accountants, and brokers were regrouped in the category of Business, small dealers, grocers, coffeehouse owners, and undertakers composed the Low Level Business group.

Note 2: Due to rounding, totals do not equal $100 \%$.

Sources: Gardner's New Orleans City Directory for 1861, 1865, 1866; Census Reports, New Orleans, 1860, 1870, Microfilm Room, National Archives; New Orleans Bee, March 12, 13, 1864; New Orleans Picayune, March 10, 11, 12, 13, 1866; New Orleans Times, March 12, 13, 1866; New Orleans Tribune, March 13, 1866.

to the military authorities contesting the election of John T. Monroe (Mayor), J.0. Nixon and Thomas McKnight (Aldermen), A. Bellanger (Street Commissioner) and P.G. Mohan (Controller). They were accused of being notorious rebels as yet unpardoned by the President. 91 The most interesting thing about the petition is the fact that one third of the signers served on the police force appointed by Mayor Kennedy. 92 
Table IV.2

Civil War Record of March 1866 City candidates

\begin{tabular}{|c|c|c|c|c|}
\hline Record & $\begin{array}{l}\text { ocratic } \\
\text { didates }\end{array}$ & $\%$ & $\begin{array}{l}\text { Conservative } \\
\text { Candidates }\end{array}$ & $\%$ \\
\hline Confederate army & 22 & 68.7 & 3 & 12.5 \\
\hline Confederate officeholder & 4 & 12.5 & 0 & 0.0 \\
\hline $\begin{array}{l}\text { Confederate army and } \\
\text { officeholder }\end{array}$ & 6 & 18.8 & 1 & 4.2 \\
\hline Union army & 0 & 0.0 & 2 & 8.3 \\
\hline Union officeholder & 0 & 0.0 & 2 & 8.3 \\
\hline $\begin{array}{l}\text { Union army and office- } \\
\text { holder }\end{array}$ & 0 & 0.0 & 3 & 12.5 \\
\hline $\begin{array}{l}\text { Confederate army and } \\
\text { Union of ficeholder }\end{array}$ & 0 & 0.0 & 8 & 33.4 \\
\hline $\begin{array}{l}\text { Confederate and Union } \\
\text { army }\end{array}$ & $\underline{0}$ & 0.0 & 5 & 20.8 \\
\hline Total & 32 & 100.0 & 24 & 100.0 \\
\hline
\end{tabular}

Sources: Index of troops from Louisiana serving in the Confederate Army, Microfilm Room, National Archives; Index of troops from Louisiana serving in the Union army, Microfilm Roon, National Archives; New Orleans Bee, 1861 to 1866, New Orleans Picayune, 1861 to 1866; New Orleans Times, 1863 to 1866; New Orleans Tribune, 1864 to 1866.

General Canby decided to suspend John T. Monroe, the mayor-elect, and J.0. Nixon, an alderman-elect, before proceeding to the installation of the new city administration. When Monroe and Nixon journeyed to Washington to receive Presidential pardons, the new administration with George Clarke as acting Mayor, was installed on March 20 as provided by the city charter when the mayor was temporarily absent. 93 
The change of city administration did not bring any major improvement. Putting new men in office did nothing to improve the ethical tone of the city administration. The new city officers, like the former ones, continued to consider the city goverment as a "fat cow" that they could despoil with impunity. First, a new police force was appointed, with 4000 applicants competing for the 500 po:sitions at a salary of $\$ 80$ per month. Second, the new administration increased the salary of city officers by about 20 to 30 per cent. 94

By April 1866 both parties were getting ready for a new contest. This time they were competing for the offices of sheriff, clerks of the district courts, justices of the peace and constables for the different parishes of the state. The only change as far as the parish of New Orleans was concerned was that the Conservative party had changed its name to the National Union Workingmen's party, and had attracted a large number of workingmen to its ticket (See Table IV.3). However, the radical element boycotted the election, and Harry T. Hays, former Confederate General and candidate for sheriff, ${ }^{95}$ led the Democrats to a sweeping victory.

The legislature which adjourned on March 22, had succeeded in isolating Governor Wells by destroying his influence over the Democratic party and the legislature, diminishing the President's confidence in him, and depriving him of control over the city administration. By April 1866 Wells was virtually alone. ${ }^{96}$

Embittered by his fight with the legislature, Governor Wells was ready to use any means to get the Democratic party out of power; even if it meant supporting the radicals and a policy that he had rejected less 
Table IV.3

Occupation of May 1866 candiates

$\begin{array}{lcccr}\text { Known-Occupation }{ }^{1} & \begin{array}{c}\text { Democratic } \\ \text { Candidates }\end{array} & \% & \begin{array}{c}\text { Conservative } \\ \text { Candidates }\end{array} & \% \\ \text { Business } & 2 & 9.5 & 2 & 8.0 \\ \text { Professional } & 5 & 23.8 & 5 & 20.0 \\ \text { Small business } & 1 & 4.8 & 2 & 8.0 \\ \text { Low level Professional } & 11 & 52.4 & 3 & 12.0 \\ \text { Skilled Worker } & 2 & 9.5 & 10 & 40.0 \\ \text { Laborer } & -0 & -0.0 & \underline{3} & 12.0 \\ \text { Total } & 21 & 100.0 & 25 & 100.0\end{array}$

Note 1: Anybody who held such occupation as doctor, lawyer, minister, reporter or teacher was considered as professional, while clerk and bookkeeper were seen as Low level professional. While bankers, merchants, accountants, and brokers were regrouped in the category of Business, small dealers, grocers, coffeehouse owners, and undertakers composed the Low level Business group.

Sources: Gardner's New Orleans City Directory for 1861, 1865, 1866; Census Reports, New Orleans, 1860, 1870, Microfilm Room, National Archives; New Orleans Bee, May 9, 1866; New Orleans Crescent, May 8, 9 , 1866; New Orleans Picayune, May 8, 9, 1866; New Orleans Times, May 8, 9, 1866; New Orleans Tribune, May 8, 9, 1866. Picayune, April 14, 1866; Southern Star, April 13, 1866.

than a year before. The change in the governor's mind became obvious in March 1866 when he gave his support to H.C. Warmoth's resolution calling for a state convention. On March 22, during this first participation in the Central Executive Committee's debates since his return from Washington, Warmoth proposed an election for April 20 to choose delegates for a state convention, which would assemble in New Orleans on May 1. The 
state convention would convene "with the view of framing a constitution and preparing the organization of a state government in harmony with the government of the United States." 97 In defense of his plan, Warmoth offered several arguments. First, he told the committee that such action was infonformity with the right of citizens to petition Congress. Second, he reported that the House Committee on Territories had passed a series of resolutions supporting the reorganization of the Southern states by independent action of the people. Finally, he stated that Governor Wells did not object to his proposal. 98

Crane immediately labeled the whole scheme unworkable; in fact, he opposed Warmouth's plan because he believed it came from Hahn and Banks. Crane concluded that he radicals must wait for Congress to act. 99 Although Warmoth had the support of the Tribune, whose only objection was the election of new state executive officers, ${ }^{100}$ he had been put on the defensive within the committee by Crane, Waples, and Hornor.

Unable to gain the support of the whole committee, Warmoth attempted first to have the matter referred to a subcommittee of ten. Durant opposed this maneuver on the grounds that the Central Executive Committee could not delegate such absolute power; the resolution failed by a vote of 12 to $11 .^{101}$ Meanwhile, Warmoth had attempted to gain the collaboration not only of Governor Wells, but also of General Philip H. Sheridan, commander of the Gulf Department. On April 3, he and Sheridan discussed the question of a new convention. At the end of a pleasant interview, Sheridan told Warmoth that he could be of no help and that his main concern was the maintenance of peace, but that he would place no obstacles in Warmoth's way. 102 
On April 18, the resolution for a convention came to a final vote in the Central Executive Committee, which decisively rejected it, 17 to 8 . Yet, the whole project was definitely set aside only after Durant intervened in the debates. Departing from his usual policy of nonalignment as president of the committee, Durant closed the argument for the opposition. He placed Reconstruction politics in historical perspective, told the committee that the success of Reconstruction depended upon bringing discordant elements into harmony, and argued that this would be a long process. He reiterated his previously expressed opinions that a provisional government, supported by military force, was indispensable to a final settlement, and that "the only mode in which the question must be decided is to range ourselves, on the side of Congress, against the Executive." Durant concluded by emphasizing his opposition to violence and his advocacy of popular participation; he submitted that rash acts would cause trouble and warned that "if unfortunately a collision should occur, it would be an occasion for our opponents to injure us in the judgment of the people of the United States." 103

The political career of Thomas J. Durant, perhaps the most consistent of all the Louisiana radicals, was now drawing to a close. His last public appearance at a New Orleans political meeting came on May 11,1866 , when he addressed a radical audience on the subject of the Civil Rights bill recently passed by Congress. 104 Durant had been very critical of Congress for its inaction in early 1866; now he had nothing but praise for the lawmakers. He emphasized that al though the bill only implemented emancipation, it was nevertheless an important piece of legislation. It confirmed for everyone the right to make contracts, sue, inherit property, sell or hold real estate, benefit 
equally from all laws and proceedings for the security of person and property. The bill also forbade discrimination in punishment on account of race or in the right to carry arms. The bills great defect, Durant noted, was that Congress had not conferred political equality, and he thought it unlikely that Congress would do so during the present session. But, Durant concluded, equality before the law had been achieved with the Civil Rights bill, and with it

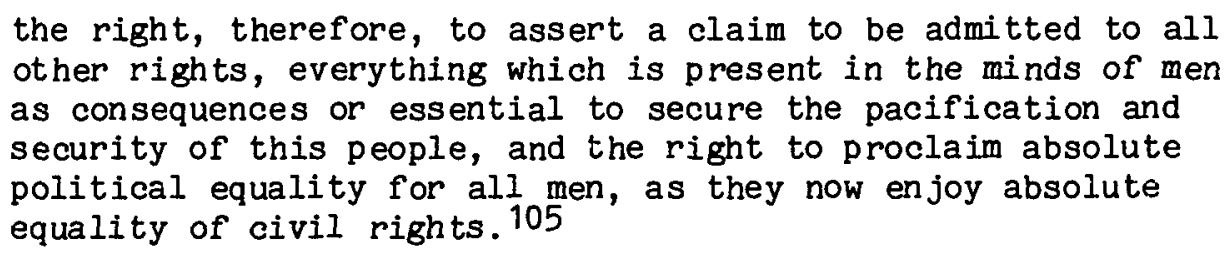

Durant's career as leader of the Republican party in Louisiana came to an end on May 24, 1866, when he refused to stand for election for another term as president of the Central Executive Committee. However, he remained a member of the committee, and was succeeded by his friend, Crane. Addressing the committee that night, Durant recognized that "this organization was only regarded as a pioneer," and pointed out many of its shortcomings. He said that it had accomplished, through the exercise of free assembly and free discussion, "a part of the work that was contemplated." Their group had also demontrated that there were men in New Orleans who saw the necessity of giving the ballot to all. Still apprehensive that Congress would leave the question of suffrage to be decided by the states, Durant concluded that the radicals should continue efforts to consolidate "with all the Union men who have seen the propriety of an extension of suffrage and form with them a large and powerful party." 106 
In the meantime, Governor Wells and the Hahn faction had decided to push for reconvening the 1864 convention, a subject that will be fully discussed in Chapter V. Durant, however, did not choose to adopt this strategy. Rufus Waples defended a resolution to offer the good wishes of the committee to the convention. The resolution was tabled at the suggestion of Oscar J. Dunn, after Durant had opposed it, declaring that the committee could not have any confidence in that convention. Durant further stated:

It is right that we should be consistent, until we have honestly changed. Not having changed, not being in favor of constitutions dictated by military orders, we must not indulge in expressions which would induce the public to believe that we have abandoned our former opinions. Moreover a convention, although legitimate in the beginning, is no longer in existence after its work has been accomplished. It cannot perpetuate itself. 107

Durant argued also that the moderates would notgratify the expectations they had aroused, that they would draft a constitution that would exclude the rebels, but would not admit the black population to vote. This would, Durant asserted, create an oligarchy, a handful of men who would control the state. Agreeing with Durant, the Central Executive Committee continued to oppose the reconvening of the 1864 convention. If some radicals sanctioned it, they did so as individuals. ${ }^{108}$

By the summer of 1866 , Louisiana politics had taken an ironical turn. Both Governor Wells and the Hahn faction, which had been up to then very conservative on the question of black suffrage, were proposing to enfranchise the black population by recalling the 1864 convention. ${ }^{109}$ Meanwhile, the radicals who had advocated universal suffrage for the last 
two years joined the conservative Democrats in opposition to the conventionists and Governor Wells' scheme. Factionalism and quest for power had made a political crisis unavoidable. 
Notes for Chapter IV

${ }^{1}$ Kennedy to Johnson, November 23, 1865, Johnson Papers, LC; Southern Star, December 29, 1865, January 8, 1866.

2Kennedy to Johnson, November 23, 1865, Johnson Papers, LC.

3 New Orleans Bee, November 8, 11, 1865; New Orleans Times, November 12, 1865; Southern Star, November 10, 13, 1865; W.M. Caskey, Secession and Restoration, $1 \overline{85-187}$; J.G. Taylor, Louisiana Reconstructed, 80 .

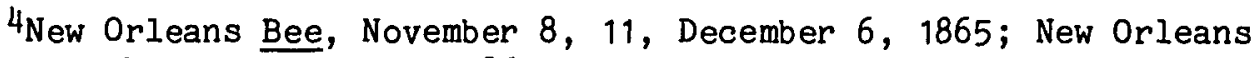
Picayune, November 21, 22, 1865; New Orleans Times, November 12, December 5, 9, 1865; Southern Star, November 1865.

5 Southern Star, November 27, 1865.

$6_{\text {New Orleans }}$ Picayune, November 28, 1865.

7 Journal of the House of Representatives of the State of Louisiana, Extra-session 1865 (hereinafter House Journal 1865) New Orleans, 1866, 1-15; Journal of the Senate of the State of Louisiana, Extra session 1865 (hereinafter Senate Journal 1865), New Orleans, 1866, 1-13; Paradoxically by early December the legislature was being heavily criticized for its non-action. After ten days, the legislature was still in a state of total confusion, having passed only one bill concerning its own expenses. The legislature's work was especially impeded by discussions over the necessity of calling a state convention. On November 23, 1865, Benjamin Flanders noted with satisfaction that the members of the legislature seemed "divided in opinions upon most of the questions upon which they are called together to act: and that "the leaders. . . will not in my opinion be restrained by sufficient prudence to prevent them from the most extreme measures. . .", he concluded with the words "let them work." See Flanders to Warmoth, November 23, 1865, Warmoth Papers, UNCA; New Orleans Times, December 5, 9, 1865; Southern Star, December 4, 1865.

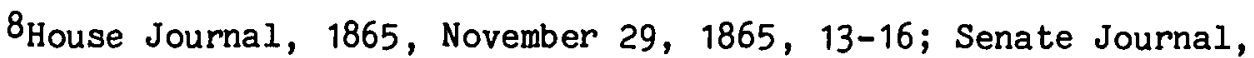
1865, November 29, 1865; New York Times, November 30, 1865; New Orleans Picayune, December 1, 1865; Southern Star, November 30, 1865; W.M. Lowrey, "The Political Career of J.M. Wells," 1066-68.

9New Orleans Times, December 23, 1865.

10House Journal, 1865, December 4, 1865, 24; N.Y. Times, December $9,1865$. 
${ }^{11}$ House Journal, 1865, November 29, December 11, 1865, 16, 37, 38; Southern Star, December 29, 1865.

12 Southern Star, December 9, 1865.

13 For details see Kennedy to Johnson, July 21, September 1, November 23, 1865, Schurz to Johnson, September 15, 1865, Johnson Papers, LC; see also Kennedy to General Mussey, Military secretary of President Johnson, August 2, 1865, Series 2, Microfilm 40, Johnson Papers; Wells to Johnson, February 10, 1866, Johnson Papers, LC; New Orleans Picayune, March 26, 1865; New Orleans Times, October 26, 1863, February 27, 1865, March 11, 1866; New Orleans Tribune, January 11, 1866; Southern Star, December 29, 1865, January 10, 1866.

${ }^{14}$ House Journal, December 5, 6, 8, 1865; Senate Journal, December $5,6,8,1865$; Hiestand to Banks, November 19, 1865, Field to Banks, November 20, 1865 Banks Papers, LC; New Orleans Picayune, November 21, 1865; Southern Star, November 22, 1865; J.R. Ficklen, History of Reconstruction in Louisiana, 116; J.G. Taylor, Louisiana Reconstructed, 81; W.M. Lowrey, "The Political Career of J.M. Wells," 1069.

15 The irony was that the conservatives talked about democratic rights and values when they were unwilling to grant those same rights to half of the Louisiana population. See New Orleans Bee, November 11, 22, 1865; New Orleans Picayune, November 17, 21, 25, 1865; Southern Star, Novemer 18, 1865; House Journal, 1865, 16, 26, 37, 39.

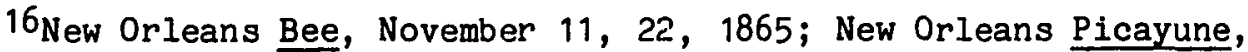
November 21, 1865; New Orleans Times, October 1, 1865; Southern Star, November 22, 27, 1865.

17The governor had before the election called the 1864 constitution a "bogus concern" and given his support to the repudiation of that constitution. However, after the election he began to perceive in such a move a threat to his own political power. W.R. Fish in a letter to Banks explained why the governor had changed his mind: "He of course opposes the measure, and is supported in so doing by his numerous appointees who see in it their own official death. There are threats of impeachment should he continue." Fish to Banks, November 26, 1865, Banks Papers, LC.

18 House Journal, November 29, December 5, 8, 11, 1865; New Orleans Bee, December 6, 1865; New Orleans Times, December 5, 9, 12, 13, 1865; Southern Star, November 22, December 6, 9, 11, 1865.

${ }^{19}$ The New Orleans Picayune continued to support the idea of a convention as the only way to settle the constitutional puzzle (Picayune, December 13, 16, 24, 1865), when the New Orleans Times opposed it on the basis of political necessity: "Unless it be recognized as binding, we have neither laws, nor judges, nor State officers, nor authorized legislature." (New Orleans Times, December 9, 30, 1865). 
${ }^{20}$ New Orleans Picayune, December 3, 1865, January 4, 1866; New Orleans Times, December 3, 1865.

${ }^{21}$ The legislature resented the fact that $\mathrm{Dr}$. Kennedy could pursue his independent policy and control the city administration by his patronage power and played a major role in the state politic as a close friend of the governor. See House Journal, December 13, 15, 1865, 46, 52; New Orleans Picayune, August 5, 19, December 3, 15, 1865, January 4, 1866; New Orleans Times, August 6, 19, December 3, 1865; Southern Star, October 8, December 9, 14, 1865.

22 New Orleans Picayune, December 15, 1865; Southern Star, December $14,16,18,1865$.

23New Orleans Picayune, January 4, 1866.

24 Emancipation had not only freed the slaves, it had also destroyed a labor system. Although the planters had gradually accepted Emancipation, they saw the need for new regulations for their own economic benefit and in order to prevent what they saw as a general demoralization among the freedmen. The military authority had since 1863 closely and drastically regulated the relations between employers and employees, postponing the development of a free labor system. By the spring of 1865 , Congress had established the Freedmen's Bureau which had to play both roles of protector of the freedmen and arbitrator between freedmen and planters. With the end of the war, the white population hoped that the Freedmen's Bureau would expire and pushed the legislature for a new labor code. See Southern Star, November 23, 1865; New Orleans Bee, December 1, 1865; for more details on the freedmen's question and Freedmen's Bureau policy see Chapter V.

25 The Freedmen's Bureau commissioner could not only interefere with state courts, as Thomas $W$. Conway did, but it could also by resorting to military force declare void and null any regulations or laws of the state or parish that affected the freedmen.

26 R.P. Constantin, "The Louisiana 'Black Code' Legislation of 1865", M.A. Thesis, Louisiana State University, 1956, 77; Constantin attempted to justify the conservative approach of the legislature on the question of labor; he shows little interest in the rights of blacks. It is, however, the most complete study of the subject. See also J.G. Taylor, Louisiana Reconstructed, 90-91.

27 Southern Star, November 23, 1865.

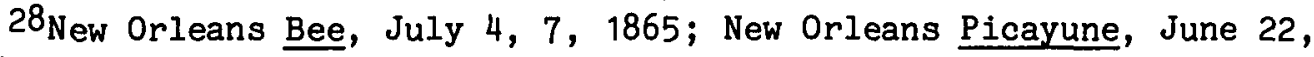
1865.

$29 \mathrm{New}$ Orleans Bee, November 8, 1865; New Orleans Picayune, November 8, 1865; New Orleans Times, November 12, 1865; Southern Star, November 8, 1865; J.G. Taylor, Louisiana Reconstructed, 384; H.W. White, The Freedmen's Bureau in Louisiana, 115. 
${ }^{30}$ Ibid; New Orleans Bee, October 28, 1865.

31 New Orleans Bee, October 28, December 1, 1865; New Orleans Picayune, November 17, 1856; Southern Star, November 23, 28, 1865; R.P. Constantin, "The Louisiana Black Code," 70 .

32 Senate Journal, November 24, 1865, 6; Letter of Governor Hahn to Senator Howe, April 1866, in Library of Congress.

33southern Star, December 14, 1865.

${ }^{34}$ Legislature, Law, Extra-Session 1865, Acts 12, 16, 20, pp 17, 24, 32; House Journal, December 18, 19, 20, 1865, pp. 58-65.

35 New Orleans Bee, December 18, 22, 1865; New Orleans Picayune, December 21, 1865; Southern Star, December 20, 1865.

36 Wells to Baird, December 18, 1865, letter received, RG 105, Freedmen's Bureau. This letter is also in Banks Papers, LC; Governor Wells was referring to the General Order No. 29, issued by Baird on December 4, 1865, which nullified even before it had passed through the legislature the black code.

37New Orleans Bee, December 16, 18, 22, 1865; New Orleans Picayune, November 28, December 21, 1865; New Orleans Times, December 14, 1865; Southern Star, December 16, 20, 1865; Commenting on the "Black Code" J.R. Ficklen, History of Reconstruction in Louisiana, 142, assumed correctly that "surely the legislators of the South must have been blind to their best interest to suppose that Congress would permit such a return to the old regime," W.M. Caskey, Secession and Restoration, 187-192, held the view that the legislators proceeded very cautiously over the question of labor legislation.

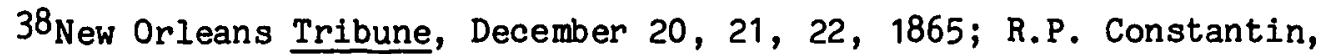
"The Louisiana Black Code," 77; J.R. Ficklen, History of Reconstruction in Louisiana, 143; J.G. Taylor, Louisiana Reconstructed, 101-103.

39Stauffer to Warmoth, December 18,1865 , Stauffer to Hahn, December 19, 1865, Warmoth Papers, UNCA; Letter of Warmoth to Senator William, February 1866, in Library of Congress; New York Tribune, November 15, 30, 1865; New Orleans Crescent, June 8, 1866; New Orleans Tribune, December 20, 21, 22, 1865; R.P. Constantin, "The Louisiana Black Code," 77; J.R. Ficklen, History of Reconstruction in Louisiana, 143; J.G. Taylor, Louisiana Reconstructed, 101-103.

40 New Orleans Crescent, December 25, 1865.

41 House Journal, December 21, 1865, pp 75; Southern Star, December 27, 1865; New Orleans Times, December 23, 1865.

42New Orleans Crescent, December 25, 1865. 
43 In spring and summer of 1866 , Louisiana suffered heavily from floods and inundations; see J.G. Taylor, Louisiana Reconstructed, 344. New Orleans Bee, December 20, 22, 1865; New Orleans Picayune, December 24, 1865; Southern Star, December 20, 1865.

${ }^{44}$ New Orleans Times, December 9, 1865; New Orleans Bee, December $6,20,22,1865$; New Orleans Picayune, December 24, 1865; Southern Star, December 20, 29, 1865; See also W.M. Lowrey, "The Political Career of J.M. Wells," 1068 .

45 As Stauffer wrote to Warmoth "Our Rebel Legislature is upsetting things generally and I trust before they get through they will upset themselves. . . Governor Wells is [doing] his utmost to hold the Legislature in check, but I am fearful they will swamp him." Stauffer wrote also to Hahn: "They had so far done nothing, but adopt measures tending toward destroying the influences of loyal citizens at Washington. They elected two rebel Senators to contest your seat, appropriate $\$ 20,000$ for the relief of rebel soldiers striking out the word Federal. They had used every effort to legislate loyal men out of office and in part nothing remains undone to complete but to vote Governor Wells out of office, and have Voorhies as Governor." Stauffer to Warmoth, December 18, 1865, Stauffer to Hahn, December 19, 1865, Warmoth Papers, UNCA. See also Southern Star, December 29, 1865, January 8, 1866.

46 Southern Star, January 8, 1866; Although many historians have recognized the existence of some differences between the governor and the legislature during the extra session of November and December 1865, they have blamed the rupture on the controversy over the city election in February 1866; but the evidence tends to show that the rupture was already complete by the end of the extra session. See W.M. Caskey, Secession and Restoration, 199; J.R. Ficklen, History of Reconstruction in Louisiana, 146-7; W.M. Lowrey, "The Political Career of J.M. Wells," 1072-74; J.G. Taylor, Louisiana Reconstructed, 81.

47Southern Star, January 8, 1866.

${ }^{48}$ National Republican, December 4, 1865; New Orleans Bee, December 20, 1865; New Orleans Tribune, December 19, 1865.

49 Warmoth diary, December 1, 1865, Warmoth Papers, UNCA.

50 Durant to Warmoth, January 12, 13, 20, 1866, Warmoth Papers, UNCA; New Orleans Tribune, January 3, 11, 20, February 17, 18, 1866.

51 Durant to Warmoth, January 12, 13, 20, 1866, Warmoth Papers, UNCA; New Orleans Tribune, January 3, 11, 20, February 17, 18, 1866.

52 Durant to Warmoth, Janury 20, 29, February 2, 4, 14, March 2, 1866, Warmoth Papers, UNCA.

53 Ibid.

${ }^{54}$ Ibid. 
55 Hiestand to Banks, November 19, 1865, Henderson to Banks, November 26, 1865, Murphy to Banks, December 1 1865, White to Banks, December 22, 1865, Plumly to Banks, January 3, 1866, Ready to Banks,, January 8, 1866, Banks Papers, LC; Sheldon to Warmoth, November 26, 1865, Warmoth Papers, UNCA; Richardson to Hon. G.S. Boutwell, November 29,1865 , and Field to James W. Greeves, November 29, 1865, both cited in Letter of Warmoth to Senator Williams, pp. 28-29.

56 Stauffer to Warmoth, December 18, 1865, Warmoth Papers, UNCA.

57 New Orleans Tribune, January 28, 1866; Southern Star, January 28, 1866; Soulie to Warmoth, February 12, 1866, Warmoth Papers, UNCA.

${ }^{58}$ Stauffer to Warmoth, February 6, 1866, Warmoth Papers, UNCA; New Orleans Tribune, February 23, March 9, 1866.

59 Warmoth diary, December 1, 1865, Durant to Warmoth, January 29, February 2, 4, 14, March 2, 1866, Warmoth Papers, UNCA; Speech of Warmoth delivered at Economy Hall on March 21, 1866, published in New Orleans Tribune, March 22, 1866.

60 W.P Mellen to Flanders, March 17, 1866, Flanders Papers, Louisiana State University Archives.

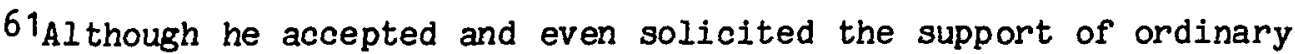
members of the Hahn-Banks moderate faction, Durant distained, as late as February 1866, all contact with the leading personalities of that faction. Durant's unwillingness to forgive Banks and Hahn's machinations appeared in his correspondence with Warmoth. On January 29, 1866, he informed Warmoth, the radical delegate purporting to represent "Louisiana Territory" in Congress, that "some colored men of this city are in correspondence with Hahn and Banks. . . Who are entirely untrustworthy, and are ready to sustain or betray, with equal cold-bloodness, any cause." Durant continued, "I am well aware that you are in daily communion with these men, but I have no confidence in them;" they were only "miserable politicians.". Then, in attempt to prove his charges, Durant added, "the policy of Banks in Louisiana placed all that I considered respectable in the Union ranks here under the heel of men who were so degraded. . . that no gentlemen could associate with them." In other letters to Warmoth on February 2, and 4, Durant described Hahn and Banks as miserable scoundrels and wretches that President Johnson used as his dirty tools. See Durant to Warmoth, January 29, February 2, 4, 1866, Warmoth Papers, UNCA.

62Stauffer to Warmoth, December 18, 1866, Warmoth Papers, UNCA.

63Southern Star, November 25, 1865; New Orleans Tribune, January 4, 1866.

${ }^{64}$ Henderson to Banks, December 24, 1865, Banks Papers, LC.

65Belden to Warmoth, February 20, 1866, Warmoth Papers, UNCA. 
66 Soulie to Warmoth, February 12, 1866, Warmoth Papers, UNCA.

67 Joumal of the House of Representatives of the State of Louisiana, Sessi on 1866, (House Journal, 1866) January 24, 1866;

Southern Star, January 26, 1866; New Orleans Picayune, January 27, 1866.

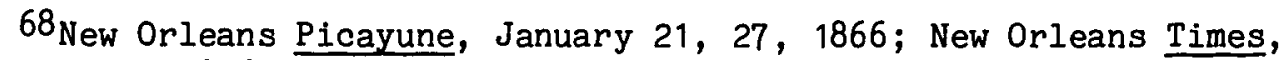
January 29, 1866; Southern Star, February 28, 1866.

${ }^{69}$ Senate Journal, February 10, 1866; House Journal, January 26, 27, February 19, 1866; Southern Star, February 28, 1866.

70 Telegram of D.S. Cage and J.B. Eustis to Hon. A.L. Tucker, House of Representatives of Louisiana, Washington, March 8, 1866, in House Journal, March 9, pp. 96-97. That the visit of the committee to Washington was opportune and averted great embarrassment is shown by the fact the telegram of Cage and Eustis, asking the legislature to drop the convention question, was received in New Orleans on March 9, 1866, and only after a vote had been taken in the House with 62 to 24 in favor of calling a convention for the first Monday of May 1866. After the telegram was received, the bill was laid on the table. House Journal, March 9, 1866, 94-95; Southern Star, March 10, 1866; New Orleans Times, March 10, 1866; See also Telegram of Wells to Johnson, March 15, 1866, and Telegram of Johnson to Eagan, Cage, Eustis, March 16, 1866, in Johnson Papers, series 2, Microfilm 41.

${ }^{71}$ Southern Star, March 23, 1866.

72 Stauffer to Warmoth, February 6, 1866, Warmoth Papers, UNCA.

73Belden to Warmoth, February 20, 1866, Warmoth Papers, UNCA; J.R. Ficklen, History of Reconstruction in Louisiana, 147, and W.M. Lowrey, "The Political Career of J.M. Wells," 1075-76, assumed correctly that Wells opposed the City Election Bill because he wanted to keep control over the city patronage.

74 Wells to Johnson, January 29, 1866, Johnson Papers, LC; and Telegram of Wells to Johnson, January 29, 1866, series 2, Microfilm 40, Johnson Papers.

75 Stauffer to Warmoth, February 6, 1866, Warmoth Papers, UNCA.

76 Telegram of Wells to Johnson, January 29, 1866, series 2, Microfilm 40, Johnson Papers; On January 19, 1866, Senator John Purcell wrote Johnson asking his views on the city election. On January 21, the president replied that he would allow the election to preceed undisturbed, provided they elect "loyal men" and that there will be no military interference. See New Orleans Tribune, March 11, 1866.

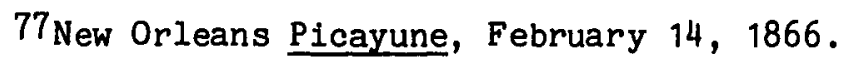

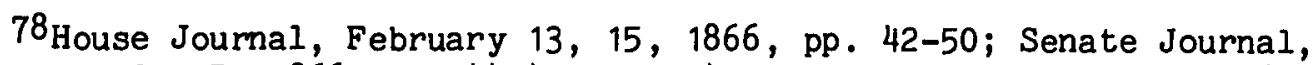
February 13, 15, 1866, pp. 44-45, 50, 74; Southern Star, February 16, 1866, W.M. Caskey, Secession and Restoration, 199. 
79 The governor had a point here, since the date fixed by the legislature for a city election did not allow the legal time necessary for the promulgation of the bill and did not provide enough time for the revision of electoral qualifications or of the registry that was necessary to prevent a return to the electoral mockery of the 1850 s.

80 House Journal, February 9, 3, 1866; Senate Journal, February 9, $13,1866$.

${ }^{81}$ Southern Star,, February 16,1866.

82House Journal, February 13, 15, 1866, pp. 44-50.

83 Ibid.

840 narch 2, 1866, Secretary Stanton sent a telegram to General Sheridan directing him to issue an order for the holding of the city elections and to assure by other orders a fair election if the governor did not order a city election in accordance with the recent act of the legislature within a reasonable time. Stanton to Sheridan, March 2, 1866, Johnson Papers, LC.

85 New Orleans Tribune, March 10, 1866.

86Southern Star, March 8, 1866; New Orleans Tribune, March 10, 11, April 4, 1866.

87 New Orleans Tribune, March 10, 1866.

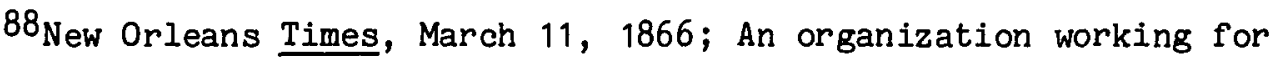
the Union party was formed among the police in order to control the election of city officers. The police officers who refused to pledge their support to that organization were summarily discharged from the force; see New Orleans Picayune, March 7, 27, 30, 1866; Grand Jury Report, in New Orleans Times, April 4, 1866, Southern Star, April 4, 1866 .

${ }^{89}$ New Orleans Times, March 25, 1866.

90 Perhas the money spent by the city had some effect on the outcome of the election, since John T. Monroe, as an example, was elected with only 300 votes of majority out of 6,500. See New Orleans Bee, New Orleans Picayune, New Orleans Times, New Orleans Tribune, March 13, 1866.

91 Petition to General Canby, March 16, 1866, Letters Received, M 1738, Gulf Department, RG 393, War Department, National Archives.

92It has been possible to establish that a third of the signers were policemen by comparing the list of petitioners with the city police roll call for 1865. The city police roll call for 1865 can be found in the New Orleans Public Library, archives section.

93Louisiana Senator John Purcell wrote to President Johnson on March 22, 1866, that "this suspension will have a salutary influence on 
a large class here. It is absolutely necessary to show them that we have a government magnanimous and forgiving to the penitent,, but able and determined to punish the contumacious. . . Purcell to Johnson, March 22, 1866, Johnson Papers, LC; see also Canby to Wells, March 18, 1866, Letters Received, Gulf Department, Canby to Secretary of War, March 20. 1866; General Order No. 26, March 18, 1866, in General Orders Book, 1866, Gulf Department, RG 393, War Department; New Orleans Tribune, March 20, 1866; Southern Star, March 21, 1866.

94 Even the arch-conservative creole paper, the New Orleans Bee, felt necessary to criticize the new administration for its multiplication offices, its salary increases, and its easy way of spending the public money. See New Orleans Bee, July 12, 1866; New Orleans Picayune, April 21, May 3, June 6, 1866; New Orleans Tribune, May 3, 1866; see also J.G. Taylor, Louisiana Reconstructed, 81-2.

95 Governor Wells communicated to President Johnson his anxiety about the election of Parish officers to be held on May 7, 1866. "I am apprehensive the parochial elections which are ordered for the seventh of May next will be but a enregistration elicit of the virtual sentiment of the State. I shall anxiously await your views as to the proper policy to be pursued." Wells to Johnson, April [30?], 1866, Johnson Papers, LC; by the way, Wells gave his support to the Workingmen ticket (see New Orleans Picayune, April 19, 1866). For the result of the election see New Orleans Bee, New Orleans Picayune, New Orleans Times, New Orleans

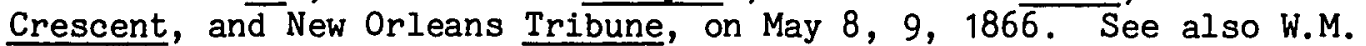
Caskey, Secession and Restoration, 202-3.

$96 \mathrm{An}$ attempt was made as late as early April 1866 to rally all Unionists (except radicals) and to form a new party. This attempt failed. See New Orleans Tribune, April 3, 1866.

97Warmoth diary, March 22, 1866, Warmoth Papers, UNCA; New Orleans Tribune, March 23, 1866; New Orleans Times, March 26, 1866.

98 Warmoth recorded his long interview with Governor Wells in his diary on March 28, 1866. The governor expressed his intention to use any means to get rid of the present state government and promised again not to oppose the radical plan. (Warmoth diary, March 28, Warmoth Papers, UNCA). See also New Orleans Tribune, March 23, 25, 27, 1866.

99 New Orleans Tribune, March 23, 1866.

$100_{\text {New }}$ Orleans Tribune, March 24, 27, 29, 30, April 20, 1866.

101 Warmoth diary, March 29, 1866, Warmoth Papers, UNCA; New Orleans Tribune, April 13, 1866.

102Warmoth diary, April 3, 1866, Warmoth Papers, UNCA.

103Warmoth diary, April 18, 1866, Warmoth Papers, UNCA; New Orleans Tribune, April 20, 1866; The New Orleans Times applauded the decision of the radicals to reject the Warmoth resolution. From the beginning the Times had vehemently opposed the whole idea, calling it a "crazy revolu- 
tionary scheme: produced by "the efforts of a few crazy disorganizers". The Times compared the acts of the Territorialists with "the deeds of the incendiary and the insane ravings of those who are sometimes brought before our courts of justice," and did not stop short of some threats. If the Times considered that "any person who, in this day of enlightenment, is crazy enough to believe in universal quality, is 'below the salt' of criticisms and almost beneath contempt," the remaining papers of the conservative New Orleans Press did not find it even worthy of mention. But this did not mean that they did not share the view of the Times. For view of the Times, see New Orleans Times, March 26, April 1, $7,24,1866$; for general view of the New Orleans Press on the question of suffrage and equality for the blacks, see New Orleans Bee, July 4 , October 7, 19, 26, 30, 1865; New Orleans Picayune, April 10, November 9, 1865, February 7, 1866; Southern Star, September 22, 27, November 25, 1865, February 10, 1866.

${ }^{104}$ The Civil Rights bill had been vetoed by President Johnson, but on April 4, 1866, Congress overrode the presidential veto.

105 New Orleans Tribune, May 12, 1866.

$106_{\text {New }}$ Orleans Tribune, May 25, 1866.

107 "Report of the Select Committee on the New Orleans Riots," House Report, No. 16, 2 sess., 39 Cong., pp. 7, 42, 70, 292-4, 440; New Orleans Crescent, July 12, 24, 1866; New Orleans Times, July 21, 1866.

${ }^{108}$ Ibid.

109 on March 28, 1866, Warmoth summarized in his diary the new position of Governor Wells and his friends: "Mr. Fish, Bullitt, Cottman, \& Governor Wells and myself had a long discussion about politics this morning, at the National Union Club during which Gov Wells said that 'By the Eternal he intended to beat the rebels and keep them from power if in doing so he destroyed the State Government and produced anarchy for twenty years. That he had fought them and would continue to do so forever. He also said that he was in favor of calling the Convention of 1864 together \& disfranchinsing the rebels and admitting negroes to vote, was not in favor of universal suffrage for the reasons that the rebels could be used to vote against us." (Warmoth diary, March 28, 1866, Warmoth Papers, UNCA). In his letter to President Johnson on April [30?], 1866, Governor Wells communicated to the President his "indirect" support for reconvening the 1864 convention: "Another party, the one which framed the constitution of 1864 and under which the present state goernment is conducted propose to reconvoke its convention as provided for by that body, its adjournment being only temporary. It is probably this is contemplated as a check move and if conducted wisely good result may be hand and quiet. . ." (Wells to Johnson, April [30?], 1866, Johnson Papers, LC; G. Granger, a close observor of the Louisiana politics wrote in summer 1866 to Hon. E. Cooper that Governor Wells was at the head of the movement to reconvene the convention of 1864 and that the main object of the movement was to regain power. (Granger to Cooper, June 11, 1866, Johnson Papers, LC). 


\section{Chapter V \\ The Impending Crisis}

It is too easy to describe the New Orleans riot of July 1866 as the product "of a spontaneous explosion of racial antipathy" and "of blind rage. . . on the part of the white mob." ${ }^{1}$ A closer study demonstrates that the riot stemmed from deeply rooted political, social, and economic causes. However, this chapter presents only the immediate origins of the riot: the social tension generated by the movement to reconvene the 1864 convention, the application of the new federal Civil RightsAct in two emotion-packed cases in New Orleans in July, and the emotional impact of the speeches given at a preliminary meeting of conventionists on Friday night, July 27.

By April 1866, some members of the old 1864 convention had concluded that the constitution they had adopted needed revision. Under that constitution two strategies were open to them. Either they could call upon the state legislature to summon a new convention, or they could ask the legislature to propose the desired amendments as provided by article 147:

Any amendment or amendments to this Constitution may be proposed in the Senate or House of Representatives, and if the same shall be agreed to by a majority of the members elected to each house, such proposed amendment or amendments shall be entered on their journals, with the yeas and nays taken there on. Such proposed amendment or amendments shall be submitted to the people at an election to be ordered by said Legislature, and held within ninety days after the adjournment of the same, and after thirty days publication according to law; and if a majority of the voters at said election shall approve and ratify such amendment or amendments, the same shall become a part of the Constitution. If more than one amendment be 
submitted at a time, they shall be submitted in such a manner and form, that the people may vote for or against each amendment separately.2

But the conventionists did not follow either alternative. Their opponents, who commanded a majority of registered voters, would probably have controlled a convention; and if the second possibility was adopted, a legislature controlled by Democrats would undoubtedly oppose the amendments they desired. The conventionists therefore decided instead to revive the convention of 1864 .

In order to achieve this goal, the conventionists needed legal grounds on which to base their action. They found such grounds in two resolutions passed by the former convention on July 25, 1864 :

Resolved, that when this Convention adjourns, it shall be at the call of the President, whose duty it shall be to reconvoke the Convention for any cause, or in case the Constitution should not be ratified, for the purpose of taking such measures as may be necessary for the formation of a civil government for the State of Louisiana. He shall also, in that case call upon the proper officer of the State to call election to be held to fill any vacancies that may exist in the convention, in parishes where the same may be practicable. Resolved, that in case of the ratification of the Constitution, it shall be in the power of the Legislature of the State, at its first session, to reconvoke the Convention, in like manner, in case it should be deemed expedient or necessary, for the purpose of making amendments or addition to the Constitution that may, in the opinion of the Legislature, require a reassembling of the Convention, or, in case of any emergency, requiring its action. 3

These resolutions, proposed by $\mathrm{R}$. King Cutler and passed 62 to 14, were meant to be used only in case the constitution had not been ratified, or if the legislature in its first session found some other pressing reason to recall the convention. Now, two years later, the constitution had long been ratified and a functioning civil government had been established 
and accepted by all political parties except the group of Radicals led by Thomas J. Durant and Benjamin F. Flanders.

In June 1866 , Judge E.H. Durell, president of the convention of 1864, was apparently ready to use the ambiguous resolutions to recall the convention. ${ }^{4}$ On June 18,1866 , he sent a telegram to William P. Fessenden, Thaddeus Stevens, and George Boutwell, all Radical congressmen, to find out if Congress would support such a move. Receiving no reply, Durell refused to sanction a recall of the convention; without congressional support he doubted that he had the legal power to do so. Moreover he did not believe that a riot could be avoided unless Sheridan provided military protection. 5

The fact that Judge Durell, who, as former president, was the only one entitled to recall the convention, refused to cooperate and in fact left the city did not stop the conventionists. They issued a call to convention members to meet on June 26,1866 :

New Orleans, June 23, 1866.

Sir: Several members of the Convention, as well as the executive, request you to attend a meeting of the members of the Constitutional Convention of the State of Louisiana, at the Mechanics' Institute, New Orleans, on Tuesday the 26 inst., at 2 o'clock p.m.

John E. Neelis, Secretary. 6

The meeting of June 26 was attended by 39 of the 96 original members of the 1864 convention. ${ }^{7}$ As Judge Durell did not attend and persisted in refusing to recall the convention, the conventionists present ousted him and named Judge R.K. Howell president pro tem. The conventionists' second action on that day was to designate July 30 , a Monday, for the 
first meeting of the full convention. They also asked Judge Howell to call upon Governor Wells "to issue writs of election for vacancies." The conventionists concluded the meeting by sending Judge Howell to Washington to obtain at least the tacit support of the Radicals in Congress. 8

The decisions made by the conventionists at the meeting of June 26 presented some legal problems. First, how could a convention, which had adjourned two years before after having completed its work, including the drafting of a constitution which had been ratified by the people, suddenly decide to reconvene and to revise that constitution? Judge Howell answered by claiming that it was an unusual period of history, and that, although the constitution provided another method of amendment, it had always been a custom in Louisiana to call a convention whenever there was sentiment to revise the constitution. Moreover, Howell added, Louisiana was not unique in this, since conventions in states such as Missouri, Mississippi, and North Carolina had survived six months to two years following their adjournment. The second problem came from the decision to oust Judge Durell. How could the convention reconvene without the sanction of its president? Judge Howell justified the unusual move on the ground that the action of the president was not absolutely necessary and the convention could legally reconvene on its own authority. ${ }^{9}$

There was also a question about the election of Judge Howell as president pro tem. First, because Judge Durell had not resigned as president, it was not certain that anyone could legally be elected president pro tem. Moreover, on May 6, 1864, Judge Howell himself had 
resigned from the convention, which had not only accepted his resignation by a vote of 55 to 22 , but had called upon the governor to order an election to fill the vacancy. ${ }^{10}$ Three days later, on May 9 , the convention had rescinded $i$ ts decision under a special motion from John Henderson, Jr. But this motion had first been rejected by a standing vote of 40 to 34 , and then accepted 45 to 29 , at a time when the convention's quorum was 76 . Could the convention legally rescind its decision to accept the resignation of Judge Howell and seat him as a full member without reelection, when his resignation had been made "en bonne et due forme"? Ironically, too, the rump convention of 39 members in June 1866 still did not have a quorum. ${ }^{11}$

Before leaving for Washington with former Governor Michael Hahn and former Attorney General Bartholomew L. Lynch, Judge Howell issued, as president pro tem, a proclamation reconvening the convention on July 30.12 That date had been selected at the request of the governor, whose support for reconvening the convention had become public by July 7.13 The meeting on July 30 was intended only "to get what the governor required--authentic evidence of the vacancies to be filled." 14 Then the governor would announce an election to fill the vacancies.

From the proclamation of Judge Howell, the resolutions of the June 26 meeting, and the conventionists' own testimony, it is possible to establish with great accuracy the main goal in reconvening the convention. Although the conventionists justified their action on the broad and noble principles of establishing impartial justice, insuring domestic tranquility, securing the blessings of liberty to all citizens, and restoring "the state to a proper and permanent position in the great 
Union of States," 15 they had at least three other reasons for wishing to amend the organic law of Louisiana.

One resulted from the patent intention of Congress, in view of the Civil Rights Act and its refusal to recognize the states reconstructed by Presidents Lincoln and Johnson, not to admit any state which had not proved its loyalty. Specifically, Congress expected that southern states would enfranchise blacks and disfranchise so-called "ex-rebels" in order to insure that only "loyal" elements could vote or hold office. Thus, to insure Louisiana's readmission, stronger measures than had so far been adopted would be necessary. ${ }^{16}$ A second reason was the anger of many conventionists and Conservative Union men at having been ousted from office in the previous state election of November 1865 and in city and parish elections of March and May 1866. ${ }^{17}$ Reconvening the convention was a way of reversing the popular verdict and returning themselves to power. ${ }^{18}$ As A. Oubre, planter and assistant-sergeant at arms at the meeting of July 30 , expressed it, the conventionists and their supporters wanted a change, because they felt abused by the rebel leaders. ${ }^{19}$ Finally, as Edward P. Brooks, reporter of the New York Times, pointed out, to insure the accomplishment of the first two objectives, the conventionists planned to control the new election not only by enfranchising freedmen and disfranchising ex-rebels, but also by arrogating "to themselves to decide who shall come in under a new election and who shall stay out." This last would be achieved by refusing to admit to the convention members who are opposed to their political views. 20 
But it is not clear how, even after writing a new constitution according to the radical principles required by Congress, the conventionists intended to achieve their goal. How did they plan to make it the constitution of Louisiana? How were they to "break the local power of the secession element" as they said they intended to do? ${ }^{21}$ Would they dictate a constitution to, the people? Would they rely solely on the support of Congress? Or would they try to have the changes ratified by popular vote? Judge Howell was at first vague on these aspects of the plan; he reported that he and the other conventionists did not intend to dictate to the people, or have Congress do so, but would seek ratification by the people. 22 But what did he mean by "the people"? Who were they? Only the registered voters? Only the white people? Only the loyal element? Or did he mean all the people without distinction of race or color? Howell subsequently clarified his position in a public letter of August 15, 1866, in which he said that the convention would submit the revisions "to all who are now legal voters and also those to whom the right of suffrage would be extended by their action." 23 Howell did not say if those who would be disfranchised by the new constitution would be allowed to vote. He later added in the same letter: "Whatever the result, it would have flown from the will of the whole loyal people," 24 which may have implied that those who were to be disfranchised would not be allowed to vote on ratification--a dangerous precedent indeed.

Judge Howell agreed that the final decision lay with Congress. The main purpose of his visit to Washington was to consult with members of Congress and win as much support as possible. The results of the visit, he acknowledged, were inconclusive at best: 
They were not as satisfactory as I had desired or expected from what I had heard; in this respect--I had the impression that there were Congressmen who had suggested the reassembling of the convention, and the submission of their work to Congress for its acceptance. That I did not find to be the case. 25

Judge Howell explained that he and the other conventionists were waiting for "some action, some resolution, or something to encourage the meeting of the convention," but that the Radicals in Washington "declined it as not belonging to the actions of Congress. "26

The movement to revive the convention was ridiculed as not having the slightest chance of success, until the support of Governor Wells became public knowledge in early July. Then the opposition among the National Democrats and their allies in the conservative press of the city, and among the civil authorities of New Orleans and of Louisiana, took the possibility more seriously.

Judge Edmund Abell of the First District Court of New Orleans, a member of the 1864 convention, was the first to question the legality of the reconvening convention. In an instruction to the Grand Jury of the parish of New Orleans in July 3, Abell charged that if the conventionists reassembled, they would be guilty of insubordination and rebellion:

I charge you that the Constitution adopted on the day of July, 1864, and submitted to and ratified by the people on the lst Monday of September of the same year, is the Constitution of the State, which all her officers, have sworn to support. I further charge you that the constitution makes no provision for the continuance of the Convention of 1864; and I further charge you that there is no convention in the state of Louisiana known to the constitution and laws of the State; that the resolution offered by Hon. R. King Cutler, by which the defunct convention claims the right to reassemble, is neither a part of the constitution or laws of the State, and furmishes no legal pretext for its pretensions, and that any effort upon the part of that defunct body to assemble, for the purpose of altering or amending the constitution, is subversive 
of good order and dangerous to the peace of the State, and any overt act to subvert the Constitution by any officers of the State who have sworn to support it renders them liable to the criminal laws of the State for misdemeanor in office and per jury. 27

It was perhaps ironical that Judge Abell who had been a conspicuous opponent of the constitution in 1864 , should now be its ardent supporter. ${ }^{28}$ But history does not ask people to remain consistent, ${ }^{29}$ and the important thing is that Abell, as judge of the First District Court where the question of the legality of reconvening would be raised, had called for the indictment of its members on the ground that they represented a threat to the public peace and to the constitution.

The indictment of any who participated in the meeting of July 30 , in Abell's view, was the way for the civil authorities to proceed; but the conventionists and their supporters rejected the authority of the court, citing three flaws in the proceedings of the court and in Abell's charge to the Grand Jury.

The first stemmed from a law passed by the last legislature which required that "all persons qualified to be jurors, have to be registered legal voters" and had to be registered before December of the previous year. ${ }^{30}$ One of Abell's 16 Grand Jurors, Raphael B. Flores, was not even a registered voter and had been in the city for only the last three months, after an absence of three years. 31 A second problem was that under Louisiana law the Grand Jury could not indict or decide criminal cases when the court was not in session. ${ }^{32}$ The last session of the court had ended on July 3, and the next session was not scheduled until November. 33 Finally, the Grand Jury violated another statute when it made public its report on the riot. ${ }^{34}$ 
Conventionists therefore could argue that the Grand Jury was not legal and had no power to indict them. The court could only issue writs of habeas corpus and admit them to bail. 35 This point was important, because, prior to the meeting of July 30 , the conventionists had already arranged with Judge Guy Duplantier, one of their supporters, ${ }^{36}$ for immediate bail in case they were arrested. 37 Moreover, they held a meeting on the morning of the riot to discuss the question among themselves. ${ }^{38}$ Clearly, they hoped to win their cases on technicalities. As a matter of fact, they would have appealed to the State Supreme Court, of which Judge Howell was a member, or ultimately to a Federal court, where they would probably have received a sympathetic hearing, if the general attitude of the Federal courts after 1862 is any indication.

Judge Abell rehearsed the same charge to the Grand Jury on July 23, adding that the constitution, since it had been ratified by the people, was the fundamental law of the state and contained in itself the provisions by which it could be altered. Any attempt to change it that was not based on these provisions was "illegal, and unconstitutional, and punishable by law." 39

Judge Abell added that contrary to the claims of his opponents, the Civil Rights Act was not a significant cause for recalling the 1864 convention to amend the state constitution, because the constitution and laws of Louisiana already incorporated the objectives of the Act and gave the Negroes the protection that they needed.

Under the laws of the State of Louisiana the colored man has precisely the same rights and redress in all cases, civil and criminal, that any white man has or can have. . .40 
Abell failed to add that article 15 of the constitution of 1864 authorized the state legislature to grant suffrage to any group:

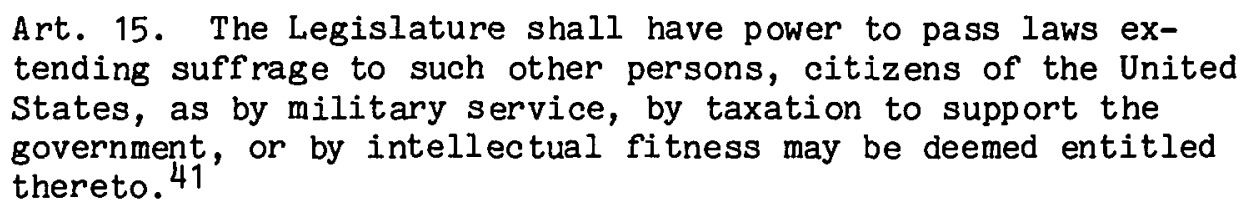

The importance of Judge Abell's charge was to provide the Democratic administration and the Democratic party a legal basis for their opposition to reconvening the convention. The Democratic press, mainly the New Orleans Bee, the New Orleans Crescent, the New Orleans Picayune, and the New Orleans Times, followed Abell's lead in attacking the "conventionist conspiracy". These papers labeled the proclamation of Judge Howell "The Rump Proclamation" and argued that Howell was without legal authority, since Judge Durell was the valid president of the convention. The Conservative Democratic press pointed out that Durell's removal was accomplished by a group who did not even form a quorum of the old convention. The New Orleans Picayune concluded with the New Orleans Times that the Cutler resolution was not a legal basis for reconvening, since it was contained only in the Journal of the Convention and had never been incorporated into the constitution or ratified by the people. Meanwhile, the New Orleans Bee and the New Orleans Crescent pointed out that the convention had expired two years before. As for Governor Wells, by supporting this "monstrous fraud" he was supporting an attempt to overthrow "the authority from which he derives title" 42

The New Orleans Picayune believed that the idea of reviving the convention originated with Governor Wells in April 1866. Having manu- 
factured an authority to be used in case of an "emergency", continued the Picayune, the conventionists proceeded to manufacture an emergency. The conventionists' project was therefore "a scheme of partisan trickery, with the object of giving aid and comfort to the adversaries of the President, by inciting disorders in Lousiana, and getting power to cast a fraudulent vote against him." 43 . Three weeks before the riot, at least one paper advanced the idea that there was a conspiracy behind the reconvening of the convention emanating from the Radicals in Congress, but presented no evidence to support the statement.

The Picayune and the Times suggested a way of resolving this question without involving the state or the city government. Although the state of Louisiana had the right to quell this "revival plot" by its own laws and authority, the two papers argued that it would be wiser to leave the whole question to the Federal executive. Since the people of Louisiana had organized their government in conformity with the plan proposed by Federal authority, they had a right to be aided and protected by that authority. 44

The reconvening of the 1864 convention generated bitterness, anger, and excitement among the majority of the white population. Their reaction was so hostile not only because the avowed goal of the conventionists was to disfranchise a portion of the white population and enfranchise the black population, but also because these supporters of the convention were members of the same group who at the election of November 1865 had defended the constitution of 1864 as the law of the land, and had strongly opposed civil equality or universal suffrage for the blacks. 45 Many opponents of the convention, who had been 
ex-Confederate soldiers or office-holders, personally disliked the conventionist leaders, such as Michael Hahn, King Cutler, Judge Howell, J.R. Terry, W.R. Fish, J.F. Mollers, and R.F. Daunoy. These men, who in the summer of 1866 professed Radical principles, had earlier been either strong advocates of secession, or Confederate officers or officeholders, and had abandoned the Confederate cause only after the fall of New Orleans. 46

The old planting and merchant aristocracy also disliked the conventionists because the latter represented a new class of politician which had arisen during the Civil War. The reassembling of the convention represented a threat to the old aristocracy which had succeeded with the end of the war in regaining its social and political ascendancy. John Lawson Lewis, former major-general in the Confederate army, explained how his class perceived the conventionists:

There is a class of men here who had any position before the war, but who now make themselves notorious. As in all revolutions, men who are the dregs of society come to surface. These are the men who profess to have become radicals, such men as King Cutler, Hiestand, and Hahn. 47

However, the old aristocracy was not alone in seeing the conventionists as adventurers. In a dispatch to General Grant on August 1, General P. H. Sheridan, the commanding officer of the Gulf Department in 1866, described the conventionists as "political agitators and revolutionary men." 48 The same point of view was reflected by William P. Kellog, a Union man, former Chief Justice of Nebraska Territory, since 1865 , collector of the port of New Orleans, and now on his way to becoming governor of Louisiana: 
Very many of them profess to be called "radicals"; but I do not regard them as representing, to any extent, the radical men of the north. I rather regard them as political adventurers; as men who have taken the peculiar views held by them politically for the purpose of personal agrandizement; men who have no more love of the Union really at heart than any others who have been outspoken secessionists. That is the opinion I have been compelled to come to from my observation since I have lived in this community, and I am satisfied the statement I have given is a truthful one. 49

But for many others, there was a more important reason to oppose the convention--by a riot, if necessary. Amendment of the constitution as proposed by the conventionists could have injured many citizens who had been Confederate soldiers. Many of them would have lost their employment in city or state government. This was especially true for the New Orleans police force, ${ }^{50}$ which had to quell the riot on July 30 . This fear of unemployment was an essential, if not determining, factor in bringing on the riot, as many contemporaries recognized. Some rioters "were afraid of the action of the convention." 51 Joseph A. Rozier, a leading Democrat who had been thoroughly unionist through the whole secession crisis, described why:

At the close of the war the confederates returned to the city in large numbers. As a matter of course a great many had gone off during the war in consequence of the military orders issued at the time. These men came back entirely impoverished, and therefore there was a great avidity on their part to hold office, and a great many of them had obtained office to the exclusion of a large portion of the Union men appointed by Governor Wells and Governor Hahn in the times of the Union regime. 52

A.P. Field, a former president of the Conservative Union party who by the summer of 1866 had become an ardent supporter of a radical revision of the constitution, stated: 
There is no doubt of that fact; and that all the office-holders --those men who had the offices--expected that, if the convention had met and accomplished its purpose, they would have made a change that would have prescribed a qualification which would have disqualified those who held the offices. . . .53

The riot thus originated mainly in a bitter fight between two opposing factions for power and office. One sought to return to power by the dubious method of reconvening a defunct convention, while opponents sought to use control of judicial and municipal offices to maintain ascendancy. 54 What stirred up an even larger portion of the white population was the attempt of conventionists and their supporters to resort to black suffrage to achieve their ends.

Opponents of the convention expressed their views in a great Democratic mass meeting at Lafayette Square on July 24 . There the Democratic party reiterated $i$ ts support for the Johnson plan of reconstruction and chose a delegation to represent the state in the National Union Convention $^{55}$ in Philadelphia on August 14. The meeting then expressed in strong terms its opposition to reassembling the 1864 convention:

Resolved, that the constitution of 1864 has been recognized by all the departments of the Government as the fundamental law of the land, and as such has been acquiesced in by the people; that the convention that framed the constitution was dissolved by the performance of the trust reposed in it; that it was without lawful authority to perpetuate its existence, and the attempt now being made by certain of its members to reinvest it with absolute power has its origin in motives purely selfish; that unable to sustain themselves under a constitution of their own creation, they seek to alter and modify it so as to enable them to obtain and keep power; that the convocation of the convention is illegal and revolutionary, and that it is the duty of the Executive, the Judiciary and the law officers of the State to take such steps as the occasion demands, to save Louisiana from the anarchy which threatens her, because of the reckless misconduct of unworthy citizens and pretended patriots. 56 
This resolution was especially ironic since but a few months earlier the Democratic legislature was restrained from calling its own state constitutional convention only by pressure from President Johnson, and because of the fact that out of the 219 persons who were listed as vicepresidents of the July 24 meeting at least 118 had served or supported the Confederacy (See Table V.1). The old political elite of the city, who had rallied in the fall of 1865 under the Democratic banner, was there. Out of the 219,49 had held city or state office in the $1850 \mathrm{~s}$ (Table V.2), 57 had been active in politics, and 35 had either been candidates for election to, or members of, the secession convention of 1861. It is worth noting that out of the 57 who played a political role in the 1850s, 49 came from either the Whig or Know-Nothing party (See Table V.3). As the elections of November 1865 and March 1866 had shown, the Democratic party of New Orleans had become the party of former Whigs and Know-Nothings. Out of the 219 who attended the July 24 meeting, 70 participated in the election of November 1865, and 35 became members of the state legislature. Participants at the meeting, moreover, represented not only the old political elite, but also the mercantile and professional upper class of the city (See Table V.4). The presence of so many properous professionals contrasted sharply with the middle class status of those who assembled on July 27 to express their support for reconvening the 1864 convention.

After the July 24 meeting, the civil authorities of Louisiana and New Orleans, assured of the support of the majority of the white population and of the leading citizens, the press, and the courts, were ready to deal with the convention through legal channels. But the civil authorities, in spite of their desire to resolve the question peacefully, 
Table V.1

Roles during the Civil War of the Participants in the July 24 Democratic meeting

\begin{tabular}{|c|c|c|c|}
\hline & Number & Relative $q$ & Adjusted $g$ \\
\hline Confederate army & 71 & 32.4 & 60.2 \\
\hline Confederate officeholders & 14 & 6.4 & 11.9 \\
\hline $\begin{array}{l}\text { Confederate army and } \\
\text { officeholders }\end{array}$ & 25 & 11.4 & 21.2 \\
\hline $\begin{array}{l}\text { Confederate sympathizers } \\
\text { (supported it financially) }\end{array}$ & 8 & 3.7 & 6.7 \\
\hline Missing data & 101 & 46.1 & --- \\
\hline Total & 219 & 100.0 & 100.0 \\
\hline
\end{tabular}

Table V.2

Officeholding in 1850 s of participants in July 24 Democratic meeting

Offices Number $\quad$ Relative $\%$ Adjusted $\%$

City office

$33 \quad 15.1 \quad 67.4$

State office

10

4.6

20.4

City and State Office

6

2.7

12.2

Missing data

$\underline{170}$

77.6

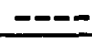

Total

219

100.0

100.0

Sources: Administration of the Mayors of New Orleans, Compiled and Edited by Work Projects Administration, 1940, City Archives, New Orleans Public Library, New Orleans Bee, 1850 to 1860; New Orleans Picayune, 1850 to 1860 , July $25,1866$. 
Table V.3

\section{Political Affiliation in the 1850s of the Participants in the July 24 Democratic meeting}

\begin{tabular}{|c|c|c|c|}
\hline Party & Number & Relative \% & Adjusted \% \\
\hline Democratic & 8 & 3.6 & 14.0 \\
\hline Whig & 26 & 11.9 & 45.6 \\
\hline Know-Nothing & 9 & 4.1 & 15.8 \\
\hline Whig to Know-Nothing & 11 & 5.0 & 19.3 \\
\hline Democratic to Know-Nothing & 2 & 0.9 & 3.5 \\
\hline Democratic to Whig & 1 & 0.5 & 1.8 \\
\hline Missing data & 162 & 74.0 & $\cdots$ \\
\hline Total & 219 & 100.0 & 100.0 \\
\hline
\end{tabular}

could not foresee that the conventionists by calling a grand mass meeting on July 27 would upset their strategy.

The meeting ${ }^{57}$ called for the night of July 27 was divided into two groups: one met inside the Mechanics' Institute and a second in the street out in front. The meeting indoors was presided over by former Governor Michael Hahn. The principal speakers were Colonel A.P. Field, president of the Conservative Union Party, and Rufus Waples, a member of the Central Executive Committee of the Republican party of Louisiana. This meeting consisted of 120 delegates, mostly professionals and small businessmen (See Table V.5), who ratified several resolutions in support 
Table V.4

Occupation of Participants in the July 24 Democratic Meeting 0ccupation 1

Number

77

44

10

19

25

10

Skilled worker

Laborer

Unkılown

Total

31

219
2

$$
\text { Relative } \%
$$

35.1

20.5

4.6

8.7

11.4

4.6

0.9

14.2

100.0
Adjusted \%

41.0

23.4

5.3

10.1

$13 \cdot 3$

5.3

1.1

$99.5^{2}$

Note 1: Anybody who held such occupation as merchant, banker, broker, planter, cotton factor, auctioneer, contractor, builder, cotton presser or manufacturer is considered as member of the highlevel business class, while doctor, lawyer, professor, harbor mastor, steamboat agent, architect, salesman and construction engineer is part of the professional class. The Small-business class regroups grocer, wholesale dealer, druggist, coffee house owner, dry goods dealer, wine and liquor dealer, tannery owner, undertaker and distillery owner. Clerk, cashier, bookkeeper and editor composes the small professional class.

Note 2: Column does not add to 100.0 due to rounding.

Sources: Census Reports, New Orleans, 1860, 1870, Microfilm Room, National Archives; Gardner's New Orleans City Directory for 1861, 1865, 1866; New Orleans Picayune, July 25, 1866.

of the convention, universal suffrage, a congressional policy of reconstruction, and the National Republican Convention in Philadelphia on the first of September. 58 


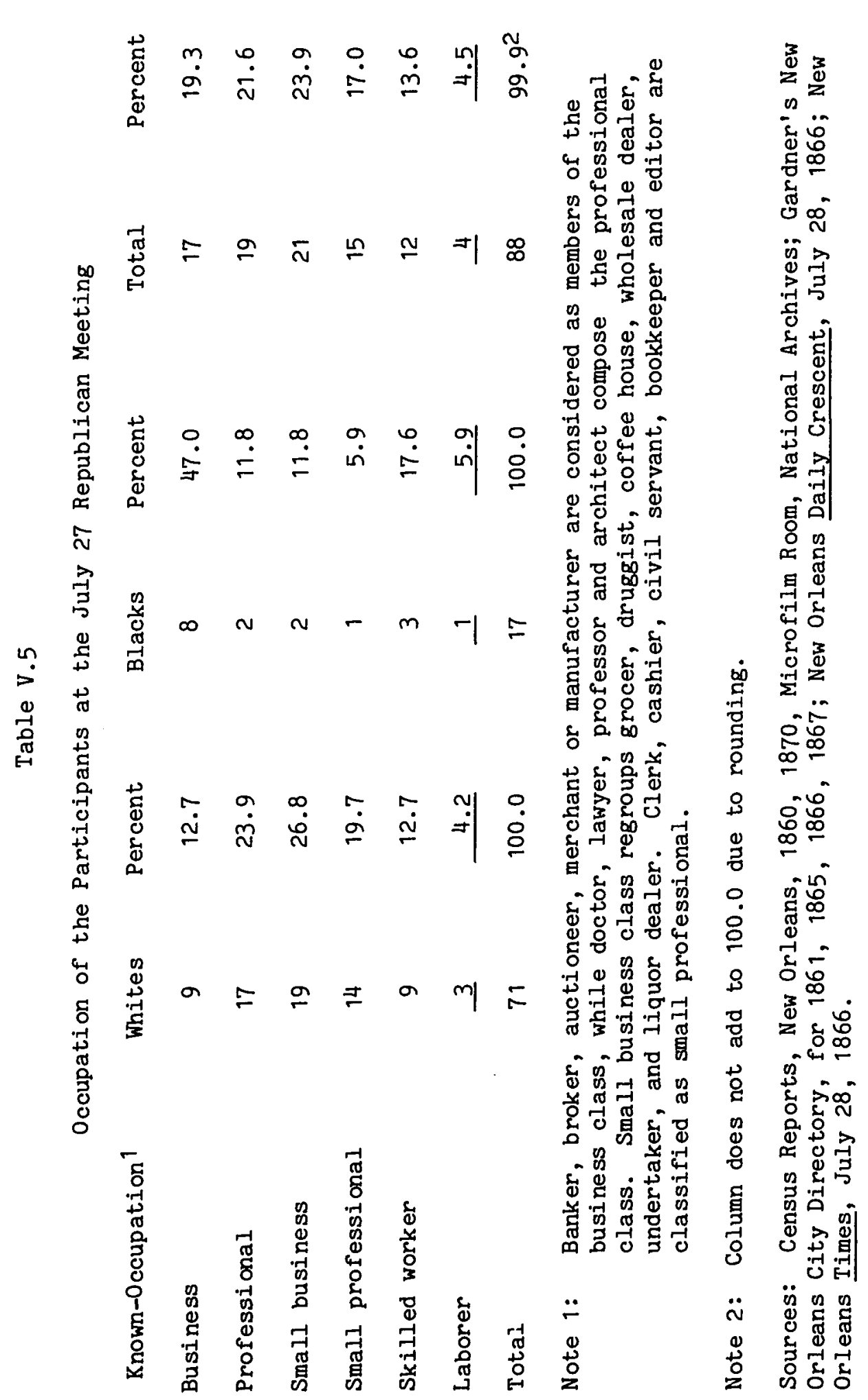


This meeting was also attended by a crowd of black people which quickly grew from 500 to 1500 persons. A large part of this crowd was standing in the street, in front of the Institute, and was addressed by different orators, including R. King Cutler, a member of the 1864 convention who had also been unseated as U.S. Senator, John Henderson, Jr., a member of the 1864 convention and a son of a former U.S. Senator from Mississippi, Judge Ezra Hiestand, former judge of the First District Court, William P. Judd, who had been appointed sergeant at arms for the July 30 meeting, H.C. Dibble, a notary public, and Dr. Anthony Paul Dostie, a former state auditor of public accounts. ${ }^{59}$ It was reported after the riot that Dr. Dostie and others made inflammatory speeches predicting that blood would run in the streets and advising blacks to appear armed at the convention. 60 This meeting closed with a torch light procession at the request of Dr. Dostie. ${ }^{61}$ The procession left the Mechanics' Institute in the direction of City Hall. Quickly the procession turned into a confrontation with the police, in which two blacks were killed, four policemen were wounded, and ten blacks were arrested. 62

An important issue in assessing blame for this violence is $\mathrm{Dr}$. Dostie's address: how provocative was it? One problem is that it is difficult to know what he really said; the only existing version of his speech was published by the Democratic press, while Republican papers avoided mentioning it. 63 Even the Chicago Tribune, and Emily Reed's Life of Dr. Dostie, which printed at length all the other speeches of that night, did not, for some reason, include a word of what Dr. Dostie might have said. The two newspapers that carried the speech were the New Orleans Bee and the New Orleans Times, the first in French, the 
second in English. ${ }^{64}$ Each version was the same; but since the publication was on August 3, a week after the speech was delivered and four days after the riot on July 30 , these accounts are suspect.

There is evidence corroborating the newspaper version from two witnesses. F.W. Tilton, a businessman unsympathetic to the convention, reported that he heard Dostie say: "The very stones of the streets of New Orleans ory for the blood of these traitors, these rebels. We shall have a meeting here on Monday, in this hall in the second story, come armed; we want no cowards; come armed; if any white man molest you knock him down." 65 Tilton added that he went on . Saturday morning to see the chief of police but met only one of his aides, Smith Izard, who told him not to worry. ${ }^{66}$ The other witness was M.B. Brady, also a merchant unsympathetic to $\mathrm{Dr}$. Dostie and to the goals of the convention. Brady reported having heard Dostie advising "the negroes to insist upon their rights and if they did not get them to make the streets of New Orleans run with the blood of the rebels." 67 These witnesses are supported in some respects by others.

Richard L. Shelby, reporter for the New York Tribune, testified that Dr. Dostie:

congratulated the negroes on having conducted themselves so very quietly and orderly during the evening. He recommended them to go quietly to their homes. If they were assaulted and knocked down by anyone he would advise them to defend themselves, and if necessary to save their own lives to kill the party who assaulted them. 68

Another member of the convention, Dr. W.R. Hire, heard similar words from Dostie: "Now my friends, go peacefully home, go orderly, do not disturb anybody; but if anybody, disturbs you, kill him."69 Judge 
Hiestand declared that Dostie said something like "it was time to show the rebels that they were not to enjoy power any longer; and that they ought to be hung. Remarks of that kind; I cannot give the exact expression." 70 Stephen F. Fish, nephew of one of the members of the convention, testified that some of the speakers strongly urged the blacks to come in strength to the convention meeting on Monday, July 30. 71 However, some witnesses, such as James L. Andem, R. King Cutler, and Rufus Waples added that the meeting was conducted peacefully and that no inflammatory speeches were made. ${ }^{72}$ Still, the partisan character of all these witnesses requires caution.

Greater reliance can be placed on what the press reported in the days before the riot. A close reading of the newspapers on Saturday morning, July 28 , reveals that, while the press found Dostie's speech "inflammatory", there was no mention of "bloody threats." The New Orleans Crescent published the speech of John Henderson, Jr., in which Jefferson Davis was denounced and the "niggers and yankees" pictured as the only loyal people of Louisiana. ${ }^{73}$ The Crescent also reported the speech of W.P. Judd who said that the goal of the meeting was to give strength and backbone to the convention, but it failed to mention any speech by Dostie. ${ }^{74}$ The New Orleans Bee and the New Orleans Times confirmed only that the advice Dostie gave to the Negroes was if they were "molested by white men, kill them."75 However, the New Orleans Picayune added that Dostie advised the Negroes to appear armed at the Convention and to defend themselves if attacked. 76

From what is known of Dostie's personality, it is not inconceivable that he made a rabblerousing speech. He enjoyed calling himself the 
"Robespierre of New Orleans," $" 77$ and he had often played the role of political agitator. Before leaving New Orleans in 1861, he had said: "I hate no human being, but rebellion to republican principles, and I will never cease to denounce it in bitter terms. Principles rise superior to men in this conflict between freedom and slavery, and I would rather see every human being wiped out from the Southern States, than to behold the triumph of treason." ${ }^{78}$ In 1862, after the fall of New Orleans, he returned to the city, and having been appointed to the School Board, he stressed the necessity of a purge in order to "make treason odious. "79 In May 1863, he led members of the Union League to the Varieties Theater and forced the management to display the Union flag and have the orchestra perform patriotic airs. His demands provoked a strong reaction among the audience and forced the military authorities who were in the theater to intervene. Following that incident, the military authorities issued an order that no one could interfere with the program at any theater. ${ }^{80}$ Twice, on June 14 and 17 , 1865, he had confrontations with the police. The first occurred because he refused to leave his office; he had been elected as state auditor in February 1864, but had been removed when a technicality gave Governor Wells an opportunity for a political purge. The second came when he attempted to disrupt a mass meeting in honor of the governor. 81 He only joined the Radical group of Thomas J. Durant in February 1866 after President Johnson failed to appoint him Surveyor of the Port of New Orleans. 82

Even if the words were "put into [Dostie's] mouth by his enemies. . . as this version of his remarks was widely disseminated, it did, undoubtedly have much effect in exciting the public mind." 83 So said General 
Absalom Baird, commanding officer at the time of the riot. Whether or not Dostie specifically advised blacks to come and support the convention, and to be ready to defend themselves--if necessary, even to kill the white people--the belief that such language had been used, at a time of social and racial tension, inevitably inoreased the chances of violence.

In a dispatch to President Johnson on A.xgust 6, 1866, General Sheridan declared that "the speech of Dostie was intemperate in language and sentiment. . I have not given you the words of Dostie's speech, as the version was denied; but what I have learned of the man, I believe they were intemperate." 84 General Sheridan reaffirmed this view before the Congressional Committee when he testified that "I made inquiries in reference to a speech made by Dr. Dostie, at the City Hall, and I learned that the speech was inflammatory, and calculated to excite." 85 Many witnesses, such as Judge Paul E. Theard, a loyal Union man, confirmed this view that Dostie used some inflammatory language calculated to excite the population. ${ }^{86}$ In its Saturday morning edition, the Picayune presented a similar view of the previous night's occurences:

The nature of the meeting held last night, the inflammatory addresses delivered, and the noisy and disorderly conduct of the procession of colored men which formed after the meeting, is the principal subject of discussions this morning throughout the city, and well it may be.

The Picayune continued:

We learn that efforts are now made by the Chief of Police to have Dr. Dostie and others, who used such violent and incendiary language, arrested and held accountable. Also that a committee of our best citizens will wait upon the military 
authority to solicit their aid in suppressing the efforts of the few who are now using extreme measure to excite the black population against the whites. 87

From a dispatch of July 28 , the New York Times the next day gave

this report of the Friday night meeting:

After the adjournment of a negro meeting last night the negroes formed into procession and armed with clubs etc. etc. They marched howling through the streets, threatening violence to the whites. At the meeting their speakers used most violent language. 88

The Times added on July 30 , from a dispatch of the previous day;

Yesterday the Attorney-General of the State and the LieutenantGovernor telegraphed to the President of U.S. informing him of the violent and incendiary proceedings and speeches of the Republican negro meeting the night before, stating that a serious riot was feared. . .89

In a dispatch of July 31 a special correspondent of the Radical

Cincinnati Gazette also described the atmosphere of the city after the

Friday night meeting:

On Friday evening a mass meeting was held at the Convention building (the Mechanics' Institute) and defiant speeches were made by Cutler, Dr. Dostie, Judge Hiestand and others. Next day the city was all aflame. The papers reported that incendiary speeches had been made, and it was in everybody's mouth that $\mathrm{Dr}$. Dostie and King Cutler had advised the negroes to arm themselves on Monday, and stand by the Convention that was going to give them suffrage, drive off the police, shoot, stab, and destroy their enemies. . . A All day Saturday and Sunday, men talked of this revolutionary meeting and the revolutionary convention that was to meet on Monday, the inflammatory speeches and the riot we were sure to have. Pistols were purchased in large numbers, and everybody seemed preparing. 90

Later, the Military Commission reached these conclusions regarding the role the Friday night meeting played in bringing on the riot: 
With regard to the meeting on Friday night, there can be no doubt that it exercised a highly exasperating influence on the minds of the opponents of the convention. Negro suffrage was openly advocated, violent speeches were made in which "Rebels" were denounced, and there can be no doubt that a most illadvised appeal was made by one speaker to the negroes, to "come in their might" on the next Monday to the meeting of the convention. In one respect, this meeting was certainly incendiary in its effect. It fired into absolute fury the smoldering wrath of the classes alluded to, against the Convention party, and by bringing a procession of negroes to the Hall, gave a pretext for the contemplated and premeditated attack.91

The full impact of the Friday night meeting can only be understood in the context of the tension in New Orleans in July 1866. Edward P. Brooks, in a July 4, 1866 dispatch to the New York Times, wrote that "the people here are more bitter than in any other place I have yet found." 92 On the same day, C. Black wrote to General Banks that "the state of public feeling in this community at this time is appalling"; the whites are "all malignant, bitter, Rebels, with all the prejudices, \& hatred, against the US Govemment and the loyal adherents thereto, that they had during the war." 93 Such bitterness grew out of the frustration felt by ex-Confederates of all classes who had accepted in good faith the result of the war and who by the spring and summer of 1866 felt that the Radicals in Congress wanted to impose upon them unjust conditions. Having been reduced from affluence to near poverty by the destruction of the war, southern whites saw in the Radicals' demand for universal suffrage and Negro equality a desire for revenge rather than for reconciliation. 94

Different witnesses before the Reconstruction Committee acknowledged the existence of strong hostility and discontent in New Orleans and Louisiana. Stephen Powers testified that this bitterness was especially strong among the French aristocratic class of New Orleans, but he did 
not believe the black population of the city was in any danger. "The blacks will always secure better protection than in the country," reported Powers, "because in the city everything is done openly, or brought very directly to the public notice by means of the daily papers. There are always abundant witnesses of everything done. . The negroes in New Orleans, therefore, are in no particular danger of being encroached upon and oppressed." Powers cited as proof the fact that a voluntary election had been held peacefully and without molestation in November 1865.95 However, Generals Philip H. Sheridan and Lorenzo Thomas, in their testimony before the same committee, disagreed. Sheridan declared that, if military protection for freedmen was removed, he feared "there would be a great trouble. . . and a war of races to some extent would probably be a consequence." 96 To the testimony of Sheridan, General Thomas added that he believed it was necessary to keep "a force in New Orleans, because the negroes flock there in large numbers, and if there is any disposition to oppress them it will be shown there." 97 By July 1866, the bitterness of the white population had been increased by a controversy over the enforcement of the Civil Rights Act as well as the decision to reconvene the 1864 covention. Minor outbreaks of violence, of which there were at least six in July 1866, showed that Generals Sheridan and Thomas were right that in any general breakdown of law and order the blacks could become the victims.

By the summer of 1866 , the Civil Rights Act had become the center of controversy and a source of resentment among the white population. In April the conservative press, especially the New Orleans Times and the Southern Star, had expressed opposition to the act. The New Orleans Times had pictured it as an unnecessary "piece of political machinery, 
tending to centralization, and the destruction of that local control which is essential to individual liberty." 98 The Star charged that "this degradation of the American name" originated in a desire "to wreak a savage and unmanly wrong upon the helpless people of the South" and to "create the political power necessary to perpetuate the Government and its spoils in the hands of the Radicals." 99 Moreover, the Star concluded that the South would have to fight, as it had fought before, to halt "this degradation of American citizenship, this outrage upon the Southern social system with all the energy of our nature." Still the Star felt it necessary to add that "the object of protecting Southern society from the plague of negro ascendancy" could be attained without visiting violence on the blacks. 100

Although the Civil Rights Act, having been passed over the veto of President Johnson on April 4, 1866, went into effect immediately, 101 not until July 1866, after Judge Edmund H. Durell of the U.S. District Court of Eastern Louisiana supported the constitutionality of the act in the case of Mrs. Sharkey vs. John M. Back, did it become a subject of controversy in New Orleans. By holding that civil rights fell under the jurisdiction of the U.S. District Court, Durell was also affirming the supremacy of federal over state law. ${ }^{102}$ Following Judge Durell's decision, a public debate began over the legality of Louisiana's recently enacted statute on labor. In April 1866, a certain John Lockwood was arrested, tried, and found guilty before two members of the Court of Justice of the Parish of Concordia, George A. Green and James I. Normant, for hiring freedmen who were already under contract to Messrs. H.L. and L.P. Conner. Lockwood appealed the decision to the U.S. District Court and presented an affidavit before U.S. Commissioner 
R.H. Shannon, charging that the justices had violated his civil rights. The commissioner ordered the two arrested and brought to New Orleans in the custody of a deputy marshal. The news of the arrest caused widespread excitement in the population. Although the two justices were immediately released under bonds of $\$ 2500$ each, the U.S. Commissioner took the occasion to declare the state labor laws enacted by the last legislature invalid. The conservative press in response emphasized particularly that the U.S. Commissioner did not show how Mr. Lockwood had lost or had been deprived of any of the precious rights secured to him by the Civil Rights Act. ${ }^{103}$

The Civil Rights Act and its enforcement became closely connected to the controversial question of reconvening the 1864 convention in late July 1866. On July 21, Judge Edmund Abell, presiding over the First District Criminal Court of the Parish of New Orleans, was arrested and released on $\$ 500$ bail under a charge of treason for having violated certain provisions of the Civil Rights Act. An affidavit presented by Rodoph F. Daunoy charged that Judge Abell had maliciously incited "the rebellious people of the insurrectionary State of Louisiana, to resist law, be disorderly, contemptuous, and bid defiance to the enlightened wisdom of Congress and the well defined laws of the United States" when he declared in early May 1866 that the Civil Rights Act was "unconstitutional, aims at the striking down of the independence of the States, to sap the foundation of the republican government, to override the laws of the State, and to obliterate every trace of independence of the State judiciary, by disgraceful servile ends." A second allegation was that by declaring in his charges to the Grand Jury that the convention of 1864 had no legal right to reassembly, Judge Abell had endangered the 
liberties of citizens guaranteed under the Civil Rights Act. Commissioner Shannon, in ordering Judge Abell's arrest, asserted that Abell's attack on the idea of reconvening the 1864 convention was "conceived and delivered by wicked, malicious and politically prejudiced mind and heart" and was calculated to breach the peace by inciting sedition and giving aid to the enemies of the United States. 104

The Conservative New Orleans press quickly perceived the significance of the arrest of Judge Abell. The decision of the U.S. Commissioner meant that the conventionists could resort to the Civil Rights Act to thwart state laws and city regulations and to protect themselves from prosecution. The arrest of Judge Abell symbolized for the Louisiana people that the state judiciary had become a useless appendage since the power of the U.S. Commissioner superseded all state laws and authority. Not surprisingly, the conservative press saw in that development the action of "plotters and disorganizers now at work in this City, and who, for self aggrandizement, stop at no measure, it matters not how lawless, that will advance their schemes." The conservative press perceived further an attempt "to inflame and provoke our peaceful citizens to some act of violence, which may give an excuse for further revolutionary proceedings on the part of this pestilent and audacious clique, who, encouraged by radical conspirators in Washington, are seeking to embroil and disturb the peace of this community." 105

While the enforcement of the Civil Rights Act stirred up the public mind on these two different occasions, two other events occurred in early July 1866, which revealed the tense atmosphere among whites and blacks in New Orleans. On July 6 , a riot which was quieted only by the intervention of the police in force broke out in the city, causing many 
injuries and numerous arrests. The clash occurred, according to the New Orleans Crescent, because of the comment of a little white girl, who said "Oh! there goes a nigger with a flag." The black apparently became angry and began to kick the girl, quickly touching off a general melee among the numerous whites and blacks at the scene who resorted to clubs, stones, knives and fire-arms until the police arrived. Ten days later, another conflict broke out when nine whites, who had been arrested under a warrant of U.S. Commissioner Shannon for having molested blacks, were brought under guard to New Orleans and jailed in the city prison. 106

In such an atmosphere of excitement, it is not surprising that there were "strange rumors afloat" of secret societies organized without distinction of color and composed of men determined to overthrow by force the constitution and the government, and that these societies "made use of secret signs and passwords, and that Mayor Monroe and Judge Abell have been doomed." 107 Similar rumors circulated on the day of the riot; Lieutenant Governor Voorhies gave credence to them when he wrote to General Baird, "I am informed that squads of the colored population are going about in the third district of the city; that they have abandoned their work, and that others are coming into the city. . . ."108 It was also reported on July 31 that after his arrest R.F. Daunoy had made a sensational declaration about the role of Dr. Dostie in preparing a black insurrection if reconvening the convention failed. ${ }^{109}$

Under these circumstances it is not surprising that some conventionists or Union supporters may have received threats and warnings not to be at the Mechanics' Institute on Monday, July 30 . Alexander White, an ex-sergeant of the police force, reported having advised P.K. O'Conner not to go there. ${ }^{110}$ Washington G. Rockwell, policeman, was reported 
to have given the same advice to some people holding positions with the government. ${ }^{111}$ Many conventionists and Union supporters, such as Judge Ezra Hiestand, James Duane, Winfree Philipps, W.F. Crozat, R.W. Todd, and J.R. Terry, testified that they had received threats or advice to leave the city, or at least to avoid being at the Institute on Monday, July 30 , and that this advice was sometimes given by friends ten days before the riot occurred. 112 Judge Howell reported that Governor Hahn, King Cutler, and Col. Field had received such threats. ${ }^{113}$ These threats and warnings could imply a preconceived plan and thus support a conspiracy theory, as the military commission concluded, ${ }^{114}$ or they could simply reflect the tenseness of the situation and the perception that violence was practically inevitable.

In such an atmosphere of tension and excitement, the civil authorities, in consultation with the President of the United States and the military authorities of Louisiana, tried to establish a strategy to deal with the convention without a public disturbance. They knew too well that they would lose in the long run if trouble occurred. ${ }^{115}$ Their strategy assumed that the military would not interfere, except to support the action of the courts.

On July 13, 1866, Lieutenant Governor Albert Voorhies informed Joseph A. Rozier, a well-known Uni on man and attorney who had opposed secession at the 1861 convention, that he had been unanimously chosen by an informal meeting of the legislature to go to Washington to confer with President Johnson. Voorhies told Rozier that this decision had been taken the day before at a meeting held "for the purpose of deliberating upon the state of our affairs, in connection with the reconvoca- 
tion of the Convention of 1864." Voorhies conceded that "in ordinary times such a proceeding as this move of a small faction of a body, which itself did not at any time represent a serious constituency, would be considered as a solemn farce," but declared that in view of the critical national situation and the fact "that the revolution to be inaugurated here forms part of a program of the Radical Revolutionists at Washington; --it becomes, a question of prudence not to treat this matter too lightly, but taking things at the court, to prepare for all possible emergencies." Voorhies emphasized that the members of the legislature were especially concerned that "the State Government would be left to its own resources to put down the conspiracy, which aims at its overthrow." Finally, Voorhies told Rozier that he was to inform the President of the condition of affairs in Louisiana and press upon him the necessity of preventing military interference, or if Johnson declined to give such a guarantee, to obtain assurances from him as "to the nature and extent of that interference, should any trouble or collision ensue in our midst." This last objective was important, since Voorhies in a private letter to a conservative friend 17 days before the riot had already expressed the fear that trouble would occur. 116

Rozier accepted the assignment and arrived in Washington on July 27. That same day Rozier met with the President and discovered that both shared the same constitutional point of view in regard to the convention and that the President was ready to support the civil authorities. 117

Meanwhile, those authorities, mainly Mayor Monroe and Lieutenant Governor Voorhies, contacted General Baird, who was in charge of the 
District of Louisiana while General Sheridan was touring Texas. On July 25, Mayor Monroe informed General Baird that "an unlawful body of men. . . claiming to be members of the convention of 1864 ," intended to meet on the next Monday with the avowed purpose of subverting the city and state governments. The mayor also notified the general of his intention to disperse the convention in accordance with "the laws and ordinances of the city, which my oath of office makes obligatory upon me to see faithfully executed" and which "declare all such assemblies calculated to disturb the public peace and tranquility unlawful." The mayor concluded by asking the general whether or not "the projected meeting has your approbation, so that I may act accordingly." 118

General Baird answered the following day, July 26 . He began by saying that the convention did not have his approbation or the approbation of any military authority as far as he was aware, and he added that the conventionists had not asked for such approbation and that he himself would prefer to avoid interfering in questions relative to the reconstruction of the state government. Therefore, he did not intend to send a military guard to the convention. However, the general indicated that he could not understand how the mayor could take it upon himself to decide the legality of the conventionists' attempt to remodel the state government, and that he believed they, or any group, had a right to meet and discuss freely the questions concerning their civil government. Baird concluded that he could not accept or support any interference from the mayor on that question, the answer to which lay in the province of the courts. But if, in case of trouble, "you doubt the ability of your small force of police to control them [the conventionists], you have in such case only to call upon me, and I will bring to your assis- 
tance not only the troops now present in the city, but if necessary the entire force it may be in my power to assemble." 119

On Friday, July 27, Governor Wells issued writs for the election of delegates on September 3, to fill vacancies in the convention. However, the writs were not "en bonne et due forme" because Secretary of State Hardy refused to sign or endorse them with his seal. 120 Moreover, the action of the governor brought a formal protest from Lieutenant-Governor Voorhies, Secretary of State Hardy, Attorney General Herron, and Auditor Perralta as well as harsh criticism from the press. ${ }^{121}$

On Saturday morning Mayor Monroe introduced Lieutenant-Governor Voorhies to General Baird. The general reported later that before this meeting he had received a short visit from Dr. W.H. Hire, a member of the convention, who informed him of the conventionists' intention to meet on the following Monday and their fear that there might be interference from the city authorities. ${ }^{122}$ At the Saturday meeting between Baird, Monroe and Voorhies, the latter suggested that instead of the mayor and his police force arresting the conventionists, the sheriff should make the arrests after the Grand Jury had indicted the conventionists. General Baird rejected this proposal and said that he would arrest the sheriff if he attempted to carry it out, since he believed the conventionists had a right to meet. The lieutenant governor then proposed that the sheriff get General Baird's approval before proceeding with any arrests, which seemed to please the general. The meeting concluded with agreement on both sides that violence would be disastrous for the civil authorities, and that they should telegraph the President or the Secretary of War for more instructions. 123 
The civil and military authorities were able to agree upon only one point: the convention had no right to remodel the state government until its authority was decided by the courts. ${ }^{124}$ As for the right of the conventionists to assemble, General Baird believed that, like any group of citizens, "they had a right to meet, and to talk, and to resolve, provided they committed no breach of peace," ${ }^{125}$ while the civil authorities would have preferred to arrest them. Nonetheless, city and state officials submitted to the decision of the general. ${ }^{126}$ The misunderstanding with the most tragic consequence had to do with the civil authorities' alleged request for troops. ${ }^{127}$ Mayor Monroe left with the impression that General Baird would send troops to the vicinity of the Mechanics' Institute on Monday, ${ }^{128}$ while General Baird asserted that "no application what ever was made to me for the assistance of troops" at the Saturday morning meeting, and that the only purpose of the visit of the lieutenant governor and the mayor was to make sure that there would be no interference from the military. 129

Following the meeting of Saturday, July 28, Lieutenant-Governor Voorhies telegraphed President Johnson, and General Baird telegraphed Secretary Stanton. ${ }^{130}$ The president, already informed of the situation by J.A. Rozier, immediately replied that "the military will be expected to sustain, not obstruct or interfere with, the proceedings of the courts." 131 Secretary Stanton, on the other hand, did not reply to General Baird, thus leaving him without instructions. Instead, Stanton held on to the telegram and did not consult the President, 
although he must have known, if only from the contents of the general's message, what the situation was:

A Convention had been called, with the sanction of Governor Wells, to meet on Monday. The Lieutenant Governor and city authorities think it unlawful, and propose to break it up by arresting the delegates. I have given no orders on the subject, but have warned the parties that I should not countenance or permit such action without instructions to that effect from the President. Please instruct me by telegram. 132

Stanton's excuse for not answering was that "this telegram was the first information communicated to me that a convention was to be held at New Orleans" and that "upon consideration, it appeared to me that his [Baird] warning to the city authorities was all that the case then required, for I saw no reason to instruct him to withdraw protection from a convention sanctioned by the governor." ${ }^{133}$ But more likely, as Donald E. Reynolds and other historians have observed, Stanton supported the convention, yet knowing President Johnson's position, could not openly contravene his superior. Therefore, the Secretary decided to leave General Baird without instruffions in the hope that he would defend the convention. 134

However, General Baird did see in the newspaper on Monday morning, July 30; the telegram from President Johnson to Lt. Governor Voorhies, and a little later that day Voorhies showned him a transcript of the message. ${ }^{135}$ Also, he had given orders on Sunday, July 29, to the troops stationed at Jackson Barracks, three miles below Canal Street, "to hold themselves in readiness throughout the day on Monday, in case they should be required for any service." 136 
For their part, the civil authorities met on Saturday night at the mayor's office. The meeting was attended by all the state officers except the governor, and by Mayor Monroe, Chief of Police Thomas A. Adams, police sergeant Lucien Adams, former Major-General F.J. Herron of the U.S. Army, Sheriff Harry T. Hays, Judge Edmund Abell, City Attorney H.D. Ogden, former Lieutenant General Richard Taylor of the Confederate Army, and around 15 merchants. The meeting began with a report by Voorhies on the agreement that he had made with General Baird about the convention meeting. Mayor Monroe also reported that "it was agreed that the convention should be allowed peacefully to meet, and be protected by the police, in connection with the military." General Herron testified to the veracity of the foregoing and added that all the participants at the Saturday night meeting had been opposed to the use of force to break up the convention. The meeting concluded with the decision that the mayor should publish a proclamation in the newspapers calling upon the people not to disturb the convention. 137

As a consequence of this meeting, the state and municipal authorities on Sunday, July 29, called upon "the press to advise the people as to the proper conduct to be held on the next day so as to avoid all collision and riot; and the mayor issued his proclamation to the same effect." 138 on Monday morning, July 30 , all the city papers except the New Orleans Tribune published the mayor's decree:

Whereas, The extinct Convention of 1864 purposes meeting This day; and whereas, intelligence having reached me that the peace and good order the city might be disturbed, Now, therefore, I, John T. Monroe, Mayor of the City of New Orleans, do issue this my Proclamation, calling upon the good people of this city to avoid with care all disturbance and collision; and I do particularly call upon the younger members of the community to act with such calmness and propriety as 
that the good name of the city may not be tarnished, and the enemies of the Reconstruction Policy of President Johnson be not afforded an opportunity, so much courted by them, of creating a breach of the peace and of falsifying facts to the great injury of the city and State. And I do further enjoin upon all good citizens to refrain from gathering in or about the place of meeting of said extinct Convention, satisfied from recent dispatches from Washington that the deliberations of the members thereof will receive no countenance from the President, and that he will sustain the Agents of the present Civil Government and vindicate its laws and acts to the satisfaction of the good people of the city and State. 139

Two statements in this proclamation, it should be noted, leave no doubt about the mayor's desire to avoid any collision or riot: first, his warning that any collison would give the enemies of the President an opportunity to injure the executive program of reconstruction as well as the good name of the city, and second, the assurance that there was no reason to worry since the President had promised to support the proceedings of the courts with the military, if necessary. Mayor Monroe in this last point alluded to the telegram that President Johnson had sent to Lieutenant Governor Voorhies on Saturday.

The press piously followed the advice of the mayor and civil authorities to give "wise and salutary counsels to the public" by publishing a call not to disturb the convention meeting. The New Orleans Bee commented on the proclamation in these terms: "It is based on. . prudential considerations. . . .; we deem it eminently apposite to the occasion, and we trust that its recommendation of forbearance and noninterference in respect to the convention will be studiously observed on all hands." 140 To this, the New Orleans Times, referring to the Saturday night meeting at Mayor Monroe's office, added, "This is not only our advice, but the counsel of a large number of the most distinguished and respected citizens of Louisiana, who have met and consulted 
upon this important matter." In addition, the Times asked the black population to stay away from the Mechanics' Institute, since they would not be able to accomplish any good by provoking violence. ${ }^{141}$ Finally, the New Orleans Daily Crescent requested the citizens to follow the Mayor's proclamation exactly:

It is therefore, extremely important that nothing be done that may, in any way, lead to collision, or produce riotous demonstrations. The leaders of the conventioners of course desire to see difficulties and riots, tumults and military intervention. The sacrifice of life, on either side, would be very agreeable and entertaining to them, as it would enable them to repeat, in exaggerated form, all the slanders which have been heaped on our people by the radical press. Their swift and willing testimony would be taken as conclusive evidence of our "contumacious disloyalty." But the people of New Orleans have no idea of gratifying their enemies by doing anything that may be construed to their disadvantage. The admirable and timely proclamation of Mayor Monroe, which will be found in this morning Crescent, expresses the feelings and desires of this community. It is to be hoped that no inconsiderable and reckless indiscretion of violence will be permitted to mar the effect of the mayor's excellent suggestions. The people of the State are capable of vindicating any assault on their sovereignty by legal and peaceful means. The president stands behind them, and the knowledge of that fact ought to inspire them with abundant confidence. 142

Afterwards, the Military Commission, General Sheridan, General Baird, and one historian, Donald E. Reynolds said that the press shared responsibility for the riot because it had published irresponsible editorials and baseless rumors, which had increased the excitement of the population and led to violence. ${ }^{143}$ But a close examination of the papers in the days before the riot uncovers an accurate description of the social tensi on of those days rather than baseless rumors. No paper, except the Times in an editorial of July 29, published any account that can fairly be labeled a "baseless rumor"; and its story about secret societies using passwords and signs and aiming to the overthrow of the government 
was ignored by the rest of the press in the eagerness to promote peace and restrain the populace.

In order to be ready in case of disturbance, and because of his awareness of the tense state of both the population and his police, Mayor Monroe ordered the latter to remain at their stations and to rest on Sunday night. Since he had used them extensively on the two previous nights to patrol the streets of the city, he wisely judged that they needed rest if they were to be ready on Monday. Two-thirds of the 500man force had been on night assignment and, if trouble occurred, the remaining 150 men were hardly sufficient to maintain peace in a city of over 200,000 people. 144

It is obvious that the civil authorities had nothing to win by instigating a riot or other social disturbance, and they knew it. They were ready to work closely with the military authorities in order to avoid trouble, and they took all possible measures to achieve peace. To see the situation otherwise requires viewing all their acts as part of a Machiavellian and diabolical scheme calculated to provoke violence and to throw the responsiblity on the military authorities and the conventionists. It also demands the belief that they failed only because of the good sense of Northern opinion and because the plotters were bad politicians. The facts tell a different story.

The immediate casse of the New Orleans riot of 1866 is to be found in the social and racial tension caused by the reconvening of the convention, the use made of the Civil Rights Act, and the emotional impact of the "incendiary speeches" given at the Friday night meeting of July 27. The conventionists, by moving steadily to establish a radical government 
based on the black vote, by ignoring the resentment their actions generated among the white population, and by threatening a change of government which would have deprived many white people, especially ex-Confederate soldiers and office-holders, of their employment, increased this tension. Social and racial tension was also enhanced in July 1866 by debates over the Civil Rights Act. Although this debate was not directly the doing of the conventionists, their decision to resort to the Civil Rights Act for their own aggrandisement and the nullification of State authority by applying this act to New Orleans in July 1866, could only stir up the excitement of the white population. Finally, the Friday night meeting, with its controversial speeches and the emotional impact which it had throughout the city raised this tension to an unprecedented level. The civil authorities, who were initially willing to break up the convention by arresting its members, had second thoughts after General Baird objected to such action. Then they decided to call on President Johnson and ask for his assistance in order to calm the emotions of the people and to forestall violence. To this end they issued a proclamation calling on the population to remain calm.

Subsequent events proved that not everyone was ready to heed the counsel of the civil authorities and the newspapers. John W. Overall, private secretary to Mayor Monroe, reflected more than a personal opinion when he said on the morning of the riot that he did not expect any trouble, but "if a riot does break out, and the United States government wants it quelled, all it is necessary for them to do is to open the gunshops and arm the Confederate soldiers." 145 His words were recorded not only by two different reporters, R.L. Shelby of the New York Tribune and E.P. Brooks of the New York Times, but they were also confirmed by 
the fact that $\mathrm{Mr}$. Overall, along with many members of the city council, was seen on the scene of the riot. ${ }^{146}$ Still, this does not explain why so many people rushed to the riot, unless the social and racial tension generated in the last month was too strong to be assuaged by the repeated calls for restraint and calm from the civil authorities and the press. The full story of what occurred on July 30 will answer this question. 


\section{Notes for Chapter V}

1Donald E. Reynolds, "The New Orleans Riot of 1866, Reconsidered," Louisiana History, V, (Winter 1964) 27.

2Journal of the Convention, 183.

3Ibid., 170; Convention Debates, 623-624.

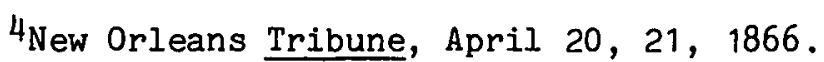

539 Congress, 2 session, House Report No. 16, "Report of the Select Committee on the New Orleans Riots," 262-3 (Hereinafter, cited as "Congressional Report, Report," and "Congressional Report, Testimony,) New Orleans Picayune, July 12, 1866.

6"Congressional Report, Testimony," 60; it is interesting to note that Neelis specified in his call that it was also issued at the request of Governor Wells.

7 New Orleans Crescent, June 28, 29, 1866; New Orleans Picayune, July 11, 1866; New Orleans Times, June 27, 28, 1866.

8"Congressional Report, Testimony," 53-57, 259-60; New Orleans Crescent, June 28, 29, 1866; New Orleans Picayune, July 12, 1866; New Orleans Times, June 27, 28, 1866; the Times reported on June 27, that Judge Durell refused to attend the meeting of June 26 , declaring "that they had assembled a the call of Governor Wells, and that he (the governor) would betray them."

9"Congressional Report, Testimony," 52-3.

10 Howell had been absented for more than 3 days, and the convention required either that he be present or resign. Howell chose to resign. Journal of the Convention, 65; New Orleans Times, July 13, 1866.

11 Journal of the Convention, 72; New Orleans Times, July 13, 1866.

12W.R. Fish to Banks, July 8, 1866, Banks Papers, LC; New Orleans Picayune, July 10, 1866.

13Ibid.; New Orleans Picayune, July 7, 1866; New Orleans Bee, July 9, 1866; New Orleans Crescent, July 9, 1866.

14 "Congressional Report, Testimony," 52; "Report of the Military Commission Investigating the New Orleans Riot," Gulf Department, RG 393, 
War Department, National Archives, 153 (only the Testimony section is paginated). Hereinafter, cited as "Military Report, Testimony," and Military Report, Documents,".

15 "Congressional Report, Testimony," 46-7; New Orleans Picayune, July $10,1866$.

16 "Congressional Report, Testimony," 7, 17, 20, 23, 31, 33, 57, $89,101,102,134,149,150,261$; New Orleans Picayune, July 11, 12, 1866 .

17 These elections and the crucial defeats that they inflicted on the Conservative Union Party (the old Free State party of Governor Hahn) were an essential factor in the evolution and radicalization of the members of this party and in the decision to reconvene the 1864 convention.

18"Congressional Report, Testimony," 6, 39, 89, 99, 101, 138, 148, $152,222,239,259,281,410$; the fight for power and of fice should not be underestimated. Control of the city administration not only made it possible for the party in power to determine the city policy, but it gave also this party a strong source of patronage with more than a thousand municipal offices.

19 "It was the idea of the men of this convention that it was for the benefit of the Union people. We were being abused here by the rebel leaders. Every man who is in office here is a rebel, and no man who has the least bit of Union sentiment in his blood or brain has the least chance; so, of course, we tried to have a chance, for we wanted to have a Uni on government." "Congressional Report, Testimony," 89.

$20_{\text {New }}$ York Times, July 31, 1866.

21 "Congressional Report, Testimony," 50.

22 Ibid., $34,52,62,63$.

23 Ibid., 54 .

${ }^{24}$ The conventionists claimed that the meeting of July 30 was only aimed to ascertain the vacancies and that they would have waited after the election of September 3, before proceeding to amend the constitution. But it seems more likely that they were to use the meeting of July 30 to organize the convention, in a word take control of it. "Congressional Report, Testimony," 55.

25 Ibid. , 56.
26 Ibid., 57.

27Ibid., 275; "Military Report, Documents,"; Judge Abell had first written a letter to the New Orleans Crescent, June 28,1866 , in which he questioned at length the motives of the conventionists and their right to reconvene the 1864 convention. 
28 Journal of the Convention, 169.

29 In this Judge Abell was no more inconsistent than Governor Wells, the conventionists, and the Democratic party, all of whom had changed their political attitude in relation to this question. The only group which had been consistent and opposed from the beginning the constitution of 1864 was the radical group of Durant, Flanders, Hornor, and Dunn.

30 "Revised Statutes of the State of Louisiana, New Orleans, 1866, 160." Cited in "Military Report, Testimony," 517-21, 522, 523, 526, 528.

31 "Military Report, Testimony," 520, 522, 532-33.

32 Ibid. , 517-21, 526, 528 .

33 Ibid.

34 Ibid. , 520, 528.

35 Ibid. , 517-21, 526, 528 .

36 Judge Duplantier was a member of the Conserative Union party in the fall of 1865, and he participated to the Friday night meeting, prior to the riot (See New Orleans Crescent, July 28, 1865).

37 "Congressional Report, Testimony," 408; "Military Report, Testimony, " 377 .

38 "Congressional Report, Testimony," 408; "Military Report, Testimony, " 218,377 . 276.

39 "Military Report, Documents, "; "Congressional Report, Testimony,"

40"Military Report, Documents,"; "Congressional Report, Testimony," 276.

41 Journal of the Convention, 171.

42New Orleans Bee, July 9, 1866; New Orleans Crescent, June 28, 29, July 9, 11, 12, 27, 1866; New Orleans Picayune, July 8, 10, 11, 12, 17, 1866: New Orleans Times, June 27, 28, July 8, 10, 12, 13, 14, 27, 1866.

43New Orleans Picayune, July 10, 12, 1866; Despite Governor Wells's denial in a telegram to President Johnson on July 28, 1866, (See Document, Military Commission), W.R. Fish, a member of the convention, testified before the Military Commission that "it was through his [Governor Wells] instigation and solicitation that the members of that convention attempted to asssemble." See "Military Report, Testimony," 173.

${ }^{44}$ New Orleans Picayune, July 14, 29, 1866; New Orleans Times, July 28, 1866; see also New Orleans Bee, July 30, 1866. 
45New Orleans Picayune, October 12, 1866; W.M. Caskey, Secession and Restoration, 176-77; J.R. Ficklen, History of Reconstruction in Louisiana, 111; W. M. Lowrey, "The Political Career of James Madison Wells," 1058-60.

46 "Congressional Report, Testimony," 222, 268, 302, 318, 387-390; New Orleans Crescent, July 24, 1866.

47 "Congressional Report, Testimony," 318.

48 Ibid., 352; Personal Memoirs of P.H. Sheridan, (New York, 1888) Vol. 2,235 .

49 "Congressional Report, Testimony," 302.

$50 \mathrm{As}$ a matter of fact, when Mayor Monroe reorganized the city police in April and May 1866, 4,000 applicants out of 12,800 registered voters (only registered voters could hold office) applied to be one of the 500 man police force. (See New Orleans Picayune, May 3, 1866; New Orleans Tribune, May 3, 4, 1866).

51 "Congressional Report, Testimony," 6, 89, 101, 152, 222, 259, $261,410$.

52 Ibid., 222.

53 Ibid., 410.

54 "Letters of General Baird to Col. Lee, August 15, 1866," in Military Report, Documents," and in "Congressional Report, Testimony," 457 .

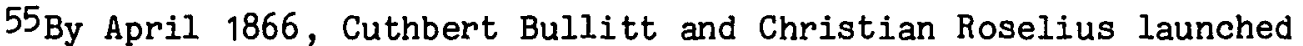
a movement to support the Johnson reconstruction program, uniting all the Union men and political factions whose ideas and position were between the Radical group of Durant and the Democratic party. But this National Union party fell short as it was unable to attract the support of the Conservative Union party and as it was infiltrated by the Democratic party. By the summer of 1866 , such a movement existed in all the states and had agreed to meet in August in Philadelphia to support the Johnson program and oppose the Radical strategy. See New Orleans Crescent, July 24, 1866; New Orleans Picayune, July 14, 1866; New Orleans Times, July 2, 10, 21, 23, 1866.

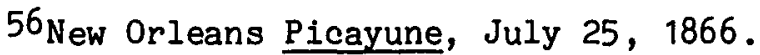

57 The conventionists had held between the meeting of June 26 and the mass meeting of July 27 , two secret meetings on July 7 and 24 , to define their strategy. New Orleans Times, July 8, 25, 27, 1866.

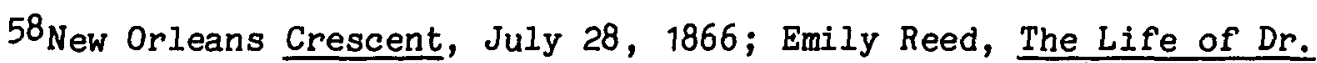
A.P. Dostie; or the Conflict in New Orleans (New York, 1868) 293. 
59New Orleans Picayune, July 28, 1866; New Orleans Crescent, July 28,1866 . 1866 .

$60_{\mathrm{New}}$ Orleans Bee, August 3, 1866; New Orleans Times, August 3,

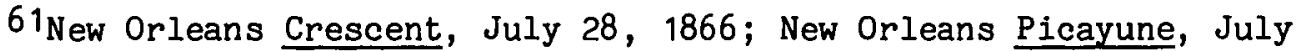
28, 1866; Chicago Tribune, August 6, 1866. 1866.

62 New Orleans Picayune, July 28, 1866; New Orleans Times, July 29,

63"Congressional Report, Testimony," 456.

${ }^{64}$ Emily Reed, The Life of Dr. Dostie, 293; Chicago Tribune, August 4, 6, 1866; New Orleans Bee, August 3, 1866; New Orleans Times, August 3,1866 .

65 "Military Report, Testimony," 232; and partially in "Congressional Report, Testimony," 380.

66 "Military Report, Testimony," 232; and partially in "Congressional Report, Testimony," 380.

67 "Congressional Report, Testimony," 312.

68 "Military Report, Testimony," 449-50; and partially in "Congressional Report, Testimony," 476.

69 "Congressional Report, Testimony," 66.

70 Ibid. , 3.

71 Ibid. , 38 .

72 Ibid., 1, 16, 32, 38, 44 .

$73 \mathrm{New}$ Orleans Crescent, July 28, 1866; this is confirmed in "Military Report, Testimony," 233.

$74^{\mathrm{New}}$ Orleans Crescent, July 28, 1866.

75New Orleans Bee, July 28, 1866; New Orleans Times, July 29, 1866.

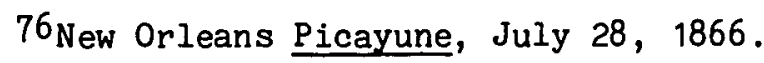

77 Emily Reed, The Life of Dr. Dostie, 130; New Orleans Times, July 29,1866 .

78 Emily Reed, The Life of Dr. Dostie, 18; Reed presents Dostie as the only true Radical of New Orleans and in the whole South.

${ }^{79}$ Ibid. , $46-48$. 
${ }^{80}$ Ibid., 59-60; New Orleans Bee, May 9, 1863; New Orleans Picayune, May 9, 10, 1863; Chicago Tribune, August 2, 1866.

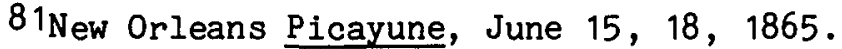

82Emily Reed, The Life of Dr. Dostie, 241-44; New Orleans Tribune, February 23, March 9, 1866.

83"Congressional Report, Testimony," 456.

${ }^{84}$ Personal Memoirs of P.H. Sheridan, 237-38.

85 "Congressional Report, Testimony," 350.

${ }^{86}$ Ibid., 376; "Military Report, Testimony," 402, 416, 515.

87New Orleans Picayune, July 28, 1866.

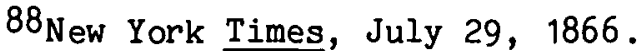

$89_{\text {New }}$ York Times, July 30, 1866.

90Dispatch reprinted in the Chicago Tribune, August 8, 1866.

91 "Military Report, Testimony,"; see also New York Tribune, October 3, 1866.

92New York Times, July 14, 1866.

93C. Black to Banks, Banks Papers, LC.

9439 Congress, 1 session, "Report of Joint Committee on Reconstruction," No. 30, part IV, General Sheridan testimony, March 31, 1866, 122-23 (Hereinafter, Joint Report on Reconstruction,); DeBow's Review, March 1866, 266-83; June 1866, 577-80; July 1866, 92; New Orleans Crescent, June 12, 15, 16, July 10, 1866.

95 "Joint Report on Reconstruction," Stephen Powers' testimony, April 9, 1866, 149.

96 "Joint Report on Reconstruction," Sheridan's testimony, March $31,1866,122-23$.

97 "Joint Report on Reconstruction, "General Thomas's testimony, April 17, 1866, 142.

98 New Orleans Times, April 9, 1866.

99 Southern Star, April 11, 12, 1866.

100 Ibid.

$101_{\text {Baird to }} \mathrm{Mr}$. Mandeville St-Clair, April 30, 1866, Endorsement, 1865-69, BRFAL; New Orleans Crescent, May 10, 1866. 


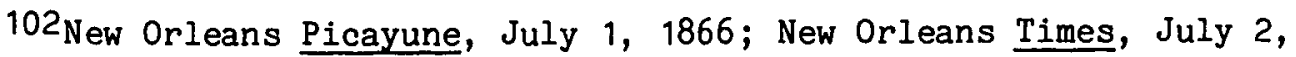
1866.

103 New Orleans Crescent, May 10, July 6, 1866; New Orleans Picayune, July $3,7,8,1866$; New Orleans Times, July 3, 8, 1866.

${ }^{104} \mathrm{New}$ Orleans Crescent, July 23, 1866; New Orleans Times, July 21, 1866.

105New Orleans Crescent, July 21, 23, 1866; New Orleans Times, July 21, 23, 1866; Chicago Tribune, July 22, 1866.

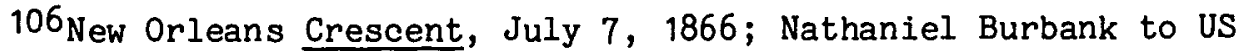
Commissioner Shannon, July 16, 1866; New Orleans Bee, July 17, 1866.

107New Orleans Times, July 29, 1866.

108 "Congressional Report, Testimony," 460; the fact is that Voorhies was without knowing it, referring to the formation of the colored procession.

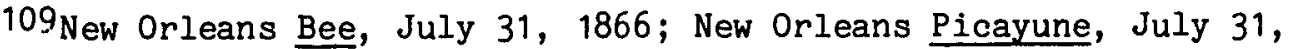
1866; New Orleans Times, August 4, 1866; In his testimony before the Military Report, S.E. Planchard denied it, while Daunoy seemed to suport it, "Military Report, Testimony," 257-58.

110 "Military Report, Testimony," 508.

111 Ibid. , 531.

112Ibid., 66-69, 205, 314, 425, 508; "Congressional Report, Testimony, " $5,10,127,279,361$.

113 "Congressional Report, Testimony," 50.

114 "Military Report, Report,"; New York Tribune, October 3, 1866.

115 "Military Report, Testimony," 419, 432-34, 452; "Congressional Report, Testimony," 236-7, 442, 457; On July 10, the New Orleans Crescent wrote about the treatment of the freedmen that "in case of a riotous gathering, if any of their number are killed they will regard the shedding of blood as an act of outrage and oppression, and will be more ready for a disturbance than before." The Crescent believed that "the radical foes of the South are laboring to bring about this state of feeling. Nothing would please them so well as to see a riot where a mob of a thousand negroes, blind, thoughtless and vindictive, should engage with a party of citizens attempting to disperse or arrest the rioter. . ." Then, the Crescent concluded that "in view of this, no other course can be advised than that of extreme forbearance towards all colored people, coupled with due vigilante and caution."

116 Voorhies to Rozier, July 13, 1866, Johnson Papers, LC; therefore, Rozier went to Washington not because the civil authorities believed that they had no power or authority to prevent the reassembling 
of the convention, as implied by W.R. Fish, but because they wanted to present to the President their views of the situation and press him to prevent any undue military interference; see "Congressional Report, Testimony," 11, 221, 225, 226.

117 "Congressional Report, Testimony," 225-26.

118 Ibid., 441, 455; "Military Report, Documents."

119 "Congressional Report, Testimony," 441, 455; "Military Report, Documents."

120 "Congressional Report, Testimony," 274.

121 New Orleans Bee, July 28, 1865; New Orleans Crescent, July 27, 1866; New Orleans Picayune, July 28, August 7, 1866; New Orleans Times.

122 "Congressional Report, Testimony," 442, 450, 456

123"Congressional Report, Testimony," 236, 237, 442, 457; "Military Report, Testimony," 419, 432-34, 452.

124 "Congressional Report, Testimony," 218-20, 236-37, 442, 457 ; "Military Report, Testimony," 160, 419-20, 432-34, 452.

125 "Congressional Report, Testimony," 442, 456-7.

126 "Congressional Report, Testimony," 219-20, 236-7; "Military Report, Testimony," 160, 419-20, 452.

127 That General Baird's version is the most accurate seems probable, since Lt. Governor Voorhies only applied for troops on the morning of the riot, after he had received from the President a telegram stipulating that the military would not interfere with, but support, the proceedings of the courts. However, it is clear that General Baird would have preferred not to have to interfere on either side. He had rejected a first demand for troops by the conventionists (Voorhies, "Congressional Report, Testimony," 237) and was ready to do it only after the lieutenant governor suggested that both sides apply for it. Moreover, another disagreement ensued about the exact hour that Voorhies made his request.

128 "Congressional Report, Testimony," 219; "Military Report, Testimony, " 160.

129"Congressional Report, Testimony," 444, 457; "Military Report, Testimony, " 433-34.

130 "Congressional Report, Testimony," 443, 458.

131 Ibid. , 443, 459.

132 Ibid. 
133 Ibid. , 546.

${ }^{134}$ Donald E. Reynolds, "The New Orleans Riot of $1866, " 10$; see also Benjamin P. Thomas and Harold M. Hyman, Stanton, The Life and Times of Lincoln's Secretary of War, (New York, 1968) 496-97; W.S. MoFeely, Yankee Stepfather, 283-4, rejects the excuse advanced by Stanton that he did not know anything since he told General Howard about the telegram, but concludes, that the Secretary of War did expect a brawl with few injuries which would show once more that the Johnsonian Governments in the South were unwilling or unable to keep the peace and adequately protect loyal Union men and freedmen.

135 Congressional Report, Testimony," 443, 444, 499.

${ }^{136}$ Ibid. , $443,458$.

137Lucien Adams had a reputation as a thug and had been appointed to the police force only a week before the riot; Harry $T$. Hays was the former commander of the Hays' Brigade of the Confederate Army. "Military Report, Testimony," 510, 512, 529, testimony of General F.J. Herron (US Army) September 8, 1866, Affidavit to Judge Hiestand by members of the convention; Grand Jury Report, testimony of Mayor Monroe; New Orleans Times, August 28, 29, 1866 .

138 "Military Report, Documents,"; Report of Mayor Monroe, Lt. Governor Voorhies, and Attorney General A.S. Herron (not General F.J. Herron) to President Johnson, also in Johnson Papers, LC, and published in New Orleans Picayune, August 7, 1866.

139 "Military Report, Documents," Mayor Monroe's proclamation; see also the New Orleans Bee, the New Orleans Picayune, the New Orleans Crescent, and the New Orleans Times, July 30, 1866.

$140_{\mathrm{New}}$ Orleans Bee, July $30,1866$.

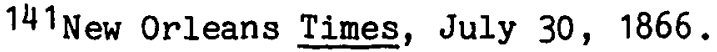

142New Orleans Crescent, July 30, 1866; The Crescent had already on July 27 advised "people of the State to give themselves no uneasiness about the convention," since "its action will amount to nothing" because no power can resuscitate a thing entirely dead.

143"Military Report, Report,"; Personal Memoirs of P.H. Sheridan (Dispatch to President Johnson on August 6) 239; this dispatch of Sheridan to Johnson is also in Johnson Papers; "Congressional Report, Testimony," 350, 456; Donald E. Reynolds, "The New Orleans Riot of $1866, " 10-11$.

144 "Congressional Report, Testimony," 219; Gardner's New Orleans City Directory, 1867, pp. 510.

145 "Military Report, Testimony," 447, 498; "Congressional Report, Testimony," 19. 
146 "Military Report, Testimony," 254; "Congressional Report, Testimony," 476 . 
Chapter VI

The "Bloody Details" of July 30

On July 31,1866 , the day after the riot, the conservative picayune observed that "the proceedings of yesterday form certainly a sad chapter in the history of our city," a day of "desperation and madness." It was very strange, "in an enlightened age like this, that such scenes can be systematically brought about against every admonition and every warning." The Picayune concluded its editorial by adding: "None regret the bloody details of yesterday more than we do--it was horrifying but there seemed no alternative; fanaticism ruled for the day. " 1 In order to get a clear view of what occurred in the streets of New Orleans and inside the hall of the Mechanics' Institute on July 30 , it is necessary not only to study the riot in its various stages, but also to answer some fundamental questions.

A black crowd began to assemble at the Mechanics' Institute as early as $90^{\prime c l o c k}$ on July 30 , three hours before the convention met. ${ }^{2}$ N.C. Snethen, Governor Wells' secretary, described this gathering of people as a disgraceful situation, ${ }^{3}$ while Judge Howell expressed his opposition to the presence of blacks and added that they were there without his approval. 4 A little after 11 o'clock, a preliminary meeting of the promoters of the convention project was called to discuss what they would do if they were arrested. Fresh from this meeting, Judge Howell asked first the Reverend $\mathrm{Mr}$. Horton and later an unidentified black to 
address the crowd in the street and to tell them that "it was not a public meeting but a convention, and that their presence was not needed, and advise them to go to their homes and business." 5 After these two had spoken, fifty or sixty of the crowd left for a while. 6

By 12:00 P.M., after Horton had offered the opening prayer, the convention was called to order and the roll taken. ${ }^{7}$ Since only 25 conventionists answered the roll call, the meeting lacked a quorum. The convention then recessed until 1:30 P.M. in order to allow the sergeant-at-arms to search for the absentees. ${ }^{8}$ Meanwhile, because of the heat, many conventionists went to a nearby bar, while the Hall began to be filled by a crowd of about 100 black and 75 white supporters or observers. ${ }^{9}$

By 12:30 P.M. a black procession which had been formed in the Third District around 11:30 A.M., was approaching the Institute. (See Map 1). The procession, at first composed of 50 or 60 people, gathered recruits as it marched, and by the time it crossed Canal Street it contained about 100 or 150 people, with a drum, a fife, and a Union flag. Edmund Campanel, a black, reported that the blacks in the procession were very enthusiastic at the prospect of receiving universal suffrage from the convention. As the procession emerged from Burgundy Street and began to cross Canal Street in order to enter Dryades Street, a row occurred. ${ }^{10}$ Witnesses on both sides stated that the row began when a white boy made an insulting remark to a black and kicked him in the back. The white crowd that was standing near laughed loudly, and the black knocked the white boy down. A melee followed. Edward Crevon, aide to the chief of police, and two civilians, Henry Clark and Marcelin Pecora, proceeded to 


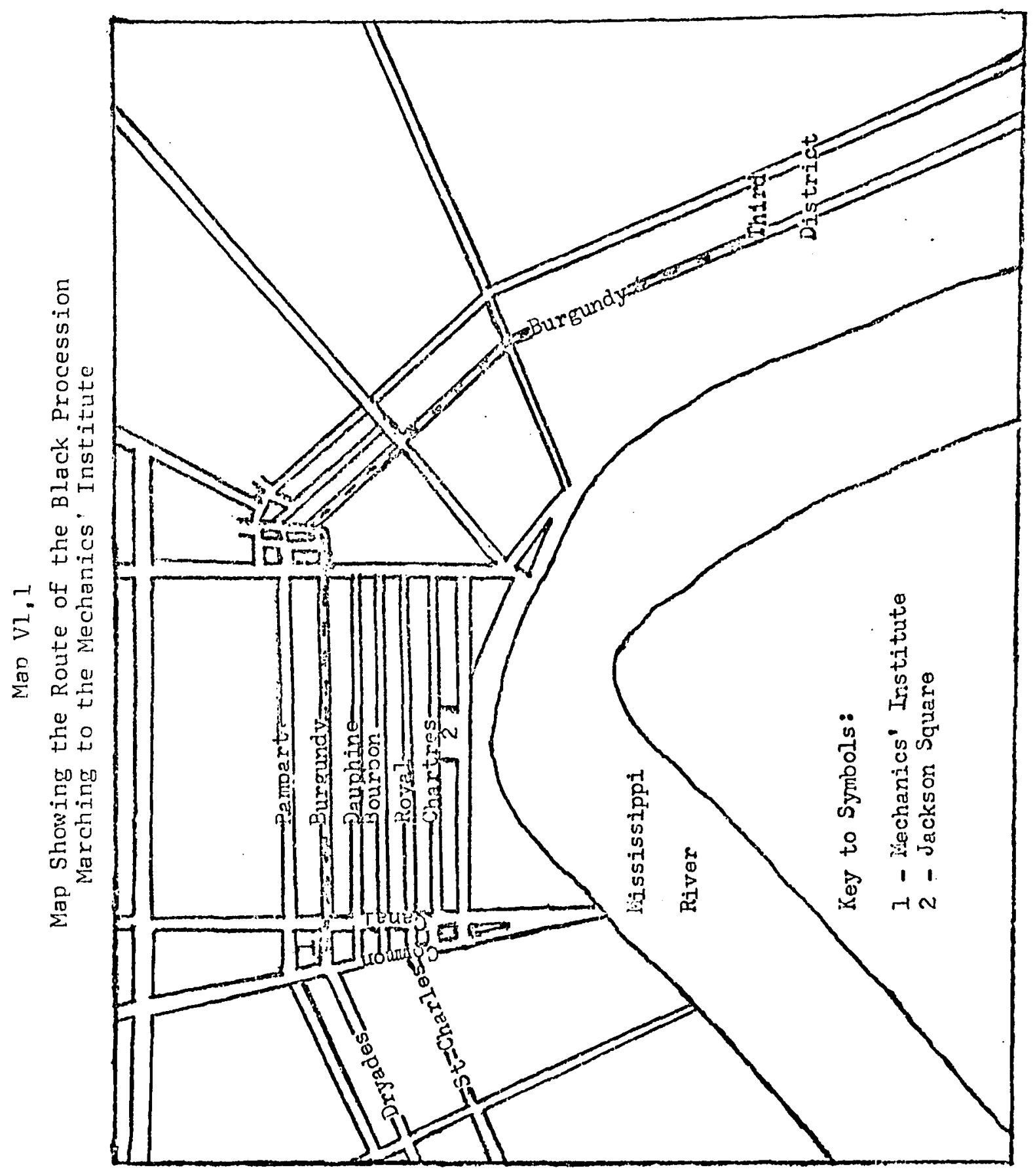


arrest the black in spite of protests and some resistance from the members of the procession, who shouted at Crevon that he was "a damned son of a bitch." Meanwhile, the flag bearer, A.L. Thibaut, ${ }^{11}$ a former lieutenant in the U.S. colored troops, responded to the jeers of the white crowd by waving his flag whereupon two or three white citizens from the white crowd sprang at him. Still, the flag bearer was able to push them down. Then City Railroad Policeman, Anthony Elmore, situated in a nearby coffee shop, fired in the direction of the flag bearer. It was the first shot fired on that day. The fire was returned by the black procession. All this created confusion and more excitement among the procession, but it finally rallied behind the flag bearer and resumed its march toward the Mechanics' Institute. Both opponents and supporters of the convention testified that the procession had become after this first disturbance not openly disorderly, but that its members were hallooing and making a lot of noise. ${ }^{12}$ Judge Howell, president pro tem of the convention, gave the following description of the procession when it arrived at the Mechanics' Institute:

Just after the adjournment, I heard music and a kind of commotion in the street, toward Canal street, and I thought I distinguished a few pistol shots. We went to the windows on the side towards Canal street. I then saw the procession, headed by music and a flag, coming up in the middle of the street. It was promiscuous--not in regular order of procession in ranks--but promiscuous, and covered the breadth of the street. 13

Arriving at the Institute around 12:45 P.M., where some 300 blacks were already assembled inside and outside of the building, the procession stopped at the front of the Institute while the flag bearer proceeded to carry his banner into the hall. Meanwhile, a white crowd which had been slowly increasing since the early morning in the streets 
adjacent to the Mechanics' Institute, was excited even more by a false report that Col. Thomas E. Adams, chief of police, had been shot. ${ }^{14}$

Rumors of a small disturbance were usually enough in New Orleans to cause excitement and attract large crowds at the scene of the commotion. On February 15, 1865, the New Orleans Times wrote that sometimes the only thing needed was for one man to look at another in a strange manner to be suddenly surrounded by a throng of observers. In short, riots and social disturbances were not unusual. ${ }^{15}$ The decision to reconvene the 1864 convention, the rash of rumors, and especially the alarming events of the previous week-end led many people to believe that something grave and important was going to occur, something they either strongly opposed or approved of. Therefore, a crowd of onlookers, excited by the situation and stimulated by the torrid weather of the day, could easily become disorderly and violent.

Different witnesses described the excitement that prevailed among a large number of white people on the morning of the 30 th. ${ }^{16}$ The beginning of the row was the occasion for many of them to rush to the scene. The Bee reported that after the fire bells had rung, "citizens from all parts of the city repaired with haste to the scene of disturbance; all was commotion and excitement, while "the fire department assembled and awaited orders from the city authorities to render any service they might be called upon to perform." ${ }^{17}$ Augustus Miller, a printer, testified that the excitement in the street and the rumor of a riot at the Mechanics' Institute distracted his employees who, when they heard a general fire alarm, rushed out to see what it was about. R.W. Todd, a student and son of Samuel $\mathrm{H}$. Todd, a merchant and assistant 
sergeant-at-arms at the convention, reported that about 11:00 A.M. Mr. Soulie, the director of Soulie's Commercial College, dismissed the students and told them to go home and stay there because there was going to be a riot, and he did not want them to get hurt. Todd stated that he went to see what was going on and to take his father away. William A. Balestier, a clerk, declared that he went to the Chief of Police's office, which was already crowded by citizens ready to be sworn in as special officers, but that the Chief of Police told them that if they had arms they should go immediately to the scene of the riot. ${ }^{18}$ This could explain the presence of a white crowd estimated at 1000 people, by A. Oubre, a planter sympathetic to the convention. J.D. O'Connell, a former Free State senator, put it at 1500.19

For at least five minutes after the Negro procession had arrived at the Institute and had merged with the black crowd already gathered there, everything was peaceful with the black crowd cheering enthusiastically in ${ }^{\text {the }}$ direction of the Hall. By one o'clock a fight, at first sporadic and then general, erupted when a young white boy shouted such epithets as "damned sons of a bitch" and gesticulated as if he was about to draw a weapon. He went as far as to pitch some bricks toward the blacks, causing them to rush at him. ${ }^{20}$ Then a police officer intervened, seized the young boy by the arms, and told him he was arrested. Meanwhile the black crowd was shouting "hang the white son of a bitch", and the white crowd was replying with similar insults. Excitement increased when some bricks were thrown in the direction of the white boy, who was by then in the custody of the policeman in proximity to the white crowd. Numerous police were already at the scene in response to the fire alarm, while scattered shots were heard. Although some witnesses such as Judge 
R.K. Howell, president pro tem of the convention, N.C. Snethen, Governor Wells' private secretary, and Pierre Sauve, a city official and former planter, implied that the first shot at the front of the Mechanics' Institute was fired by a black, others sald the first shots came from the white crowd. For example, former Federal general F.J. Herron, who followed the riot from the balcony of his office at the front of the Institute, saw the blacks throw stones at the white crowd, which responded with a volley of shots. Herron added that the blacks did not fire back immediately, and that "in the meantime scattering shots were fired by the crowd, and a volley came from the direction of the Institute. The crowd scattered, and returned the fire, giving a truly [sic] volley, which was replied from the Institute. Several persons in the crowd were wounded." By then, as General Herron and other witnesses reported, the situation had become completely confused, and the row was degenerating into a street battle. At first, surprised by the boldness of the black crowd, the police and white crowd fell back; but the police pulled themsel.ves together and began to fire on the black crowd outside the Institute. Poorly armed, the blacks began to run in every direction, attempting to use any means to protect or defend themselves, while a large number took refuge within the walls of the Institute. ${ }^{21}$

After the streets surrounding the Mechanics' Institute had been cleared of blacks, the white mob and most of the police proceeded to besiege the Institute, while within a radius of one to two miles of the Hall the blacks who had not taken refuge inside the Institute were pursued by policemen and white citizens. Many innocent blacks who had nothing to do with the convention project were pursued and shot by a wild crowd of wite citizens. 22 
Meanwhile, blacks and whjtes who hid inside the Institute soon discovered that they were not safe, for the mob and policemen were firing through doors and windows. The crowd inside the Institute responded with an occasional shot, while the leaders of the convention scheme, such as Dostie and Cutler, were advising their supporters not to resist, but only to close the windows and doors, lie on the floor, and await the arrival of Federal troops. ${ }^{23}$ But the police were convinced that the conventionists and the blacks were the riotous element. They reacted angrily to what they saw as a show of resistance. ${ }^{24}$ with the support of the white mob, they proceeded to take control of the Hall.

Itwasonly then that the city police got completely out of control. Unwilling to drive away the white mob and disregarding timid attempts made by convention supporters who waved white handkerchiefs and stated that no resistance would be made, a dozen policemen followed by a wild crowd of citizens assaulted the Institute. The police ignored the fact that conventionists and blacks were ready to surrender. They fired indiscriminately on the crowd inside the Institute, showing at first no interest in taking prisoners. The blacks and whites inside the Hall counter-attacked with broken chairs, clubs, and sticks, and any other weap on available, and drove the attackers out of the Hall. Meanwhile, the blacks who had attempted to escape by jumping out of the Institute's windows were either shot or beaten on the spot by the mob, although several whites and blacks did succeed in escaping. 25

After the first assault had been repulsed and other useless attempts to surrender had been made, John Henderson urged the people inside the Institute to rush out en masse, but the majority decided to barricade the 
doors and wait for the Federal troops to arrive. They succeeded in repulsing three other assaults before succumbing completely to the police and mob. During those assaults, scenes of the first charge were repeated; blacks who attempted to jump from windows were beaten and often killed by the mob under the eyes of policemen. ${ }^{26}$

During all that time the white mob made threatening and insulting remarks such as "Damned son of a bitch," "Damned Yankee," "Hang the damned traitor and nigger," "Killed the yankee nigger," "Shoot the nigger son of a bitch," and the like. Those remarks were directed more towards the white supporters of the convention than toward blacks. In its excitement the mob chased and assaulted any conventionists or blacks who attempted to escape. Many blacks who begged for their lives were pitilessly beaten and killed. John Henderson and Dr. A.P. Dostie were two special targets for the anger and passion of the mob. Each was dragged out of the Institute and chased by a mob howling "kill him," "kill the son of a bitch." Both were shot, stabbed, beaten, and left to die. The mob not only chased and killed those who attempted to escape, but also assaulted prisoners in the custody of the police, including ex-Governor Hahn, who was so badly assaulted after his arrest that he never completely recovered. If the police attempted to save the lives of many white conventionists, they often showed less interest in protecting blacks, many of whom were killed by the mob after having been arrested. $^{27}$ As the Picayune wrote, it was "a day of desperation and madness. 28

By 2:30 P.M., after more than one hour of resistance, the police finally took control of the Institute and arrested the few who were 
still left inside. But the white mob showed no desire to disperse. As the Picayune reported, "the bloody strife continued until at a late hour (between 3 and $40^{\prime}$ clock)" and was ended only with the arrival of Federal troops a little before 4:00 $0^{\prime}$ clock. They came in response to a request from the civil authorities. As the Picayune noted, the military authorities "appeared determined to restore order, and the crowds which had assembled at the various corners were dispersed at the point of the bayonet." 29 The city was put under martial law and the riot was over.

After the riot General Baird ordered Dr. Albert Hartsuff, an army surgeon to identify the killed and wounded. Dr. Hartsuff compiled a list of $38 \mathrm{killed}$, of whom he identified one as a member of the convention, two as loyal white citizens, one as a disloyal citizen, plus 34 blacks; of 146 wounded, eight were members of the convention, nine were loyal citizens, ten were policemen, and 119 were blacks (See Table VI.1). He verified each case by a house to house visit. ${ }^{30}$

Although this is the only official report of casualties, witnesses on either side gave slightly higher estimates of killed and wounded. Because the military authorities had already taken the position that a massacre had been planned by city officials, they had reason to produce a report showing such a lopsided distribution of casualties. The civil authorities disagreed strongly and claimed that at least 42 policemen were wounded. Thomas E. Adams, chief of police, stated that 16 policemen were wounded so badly they were unable to go on duty, 30 were slightly wounded, while two died from overexposure and three lay in a dying condition. Moreover, Chief of Police Adams presented a list of 24 severely wounded policemen to the Military Commission investigating the 


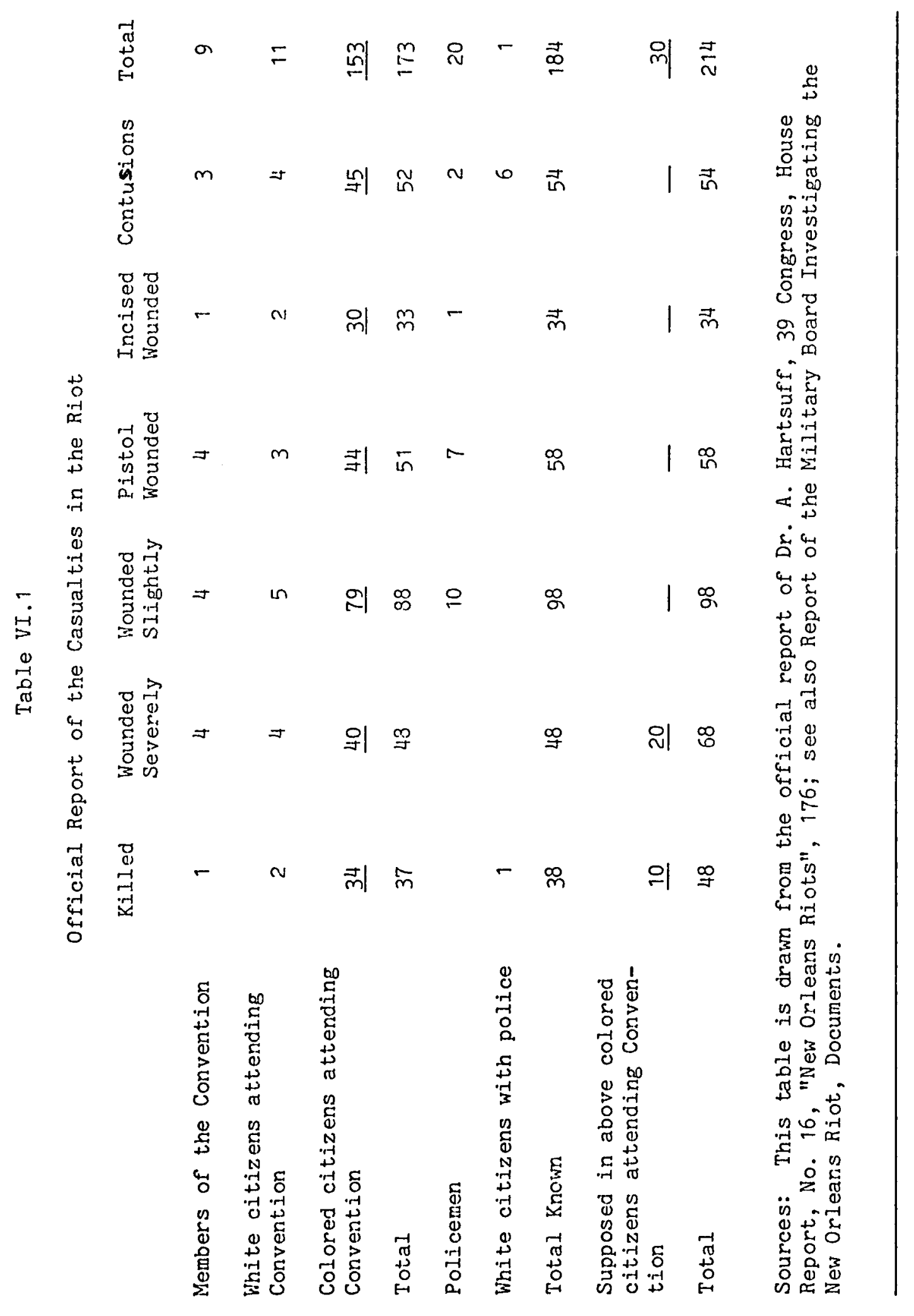


riot. 31 Finally, the Chicago Tribune, a militant Republican paper, reported that 20 to 30 policemen had been wounded during the riot, and the New York Times put the number at 50.32 Dr. Hartsuff's statement that only one "disloyal" person (that is, a member of the white mob) was killed and none wounded seems suspicious, given the size of the mob and its wild behavior. Meanwhile, some supporters of the convention, while accepting the picture drawn by Hartsuff's report, said that 300 or 400 blacks were killed or died subsequent to the riot, but most estimated the number of dead at about 100.33 The conservative New Orleans Picayune claimed that 40 or 50 blacks were killed during the riot. 34 This number seems more likely, and Richard L. Shelly, a reporter for the New York Tribune who was certainly not sympathetic to the conservatives, testified that he had made a careful investigation as to the number of killed and wounded and that he came to the conclusion that "the number could not fall much short of three hundred, for the reason that there were known to be killed somewhere between thirty and fifty." 35 Moreover, Shelly attributed the discrepancy between his and Dr. Hartsuff's estimates as to the total number of wounded to the fact that he had added, to the 150 wounded who were treated at the marine hospital, ${ }^{36} \mathrm{a}$. great number who were carried home and treated by their friends.

The discrepancy between the number of wounded and killed on both sides could partly be explained by the fact that the supporters of the convention had fewer arms than their opponents. The New Orleans Bee and the New Orleans Picayune, and some historians such as W.M. Caskey, tended to assume that the blacks came to the convention armed and attributed the smaller losses of the police and the white mob to the poor marksmanship of the blacks, 37 but the facts do not support this 
theory. In the first place, a large number of blacks had served in the U.S. colored troops and would have known how to use firearms. ${ }^{38}$

Several witnesses asserted that only a few blacks and white supporters had firearms. N.C. Snethen testified that he saw a white, R.F. Daunoy, and about half a dozen blacks with pistols on that day. 39 The only other white supporters who either admitted carrying arms or who were seen with arms on that day were former Governor Hahn, O.H. Poynot, former member of the convention, John Burke, former chief of the city police, and D.S. Haynes, former captain in the Union army. ${ }^{40}$ The view that only a few blacks had firearms is also supported by the testimony of blacks and white present at the riot. 41 Moreover, Edward Crevon, an aide to the chief of police, testified that he found no arms in the building after the riot was over. ${ }^{42}$ Meanwhile, General Sheridan, after a quick investigation, concluded that about one out of ten of the blacks who came to the Mechanics' Institute had firearms. ${ }^{43}$ But what several witnesses agreed upon was that many blacks had either clubs, canes, or sticks. 44 Furthermore, if the blacks' intention was to demonstrate support for the convention, not to create a riot, they would not be inclined to arm themselves. It was not easy for blacks to acquire guns. Those who had been mustered out of the Federal sevice had often been deprived of their muskets at the insistence of local whites. 45 And when the riot did begin, it was possible for whites to rush to nearby gun stores and buy weapons, an option not available to blacks. That situation gave the police and the white mob a firepower largely superior to their opponents.

Although the police did not receive any special orders concerning arms and were not furnished with arms by the city, some witnesses 
reported most policemen, who were told to be ready for trouble, came wearing their personal arms. ${ }^{46}$ Although small gun dealers reported selling as many as a dozen guns, mainly to citizens, on the day of the riot, testimony before the Military Commission revealed that the main source of arms and ammunition was the big gun store close to the Mechanics' Institute. ${ }^{47} \mathrm{~A}$ close look at the testimony reveals that no big sale occurred before the riot, but a clerk at House of $\mathrm{H}$. Folsom, John G. Chadwick, reported that there was a rush of customers at the beginning of the riot and that arms were bought by the best class of people. 48 J.B. Richards, a bookkeeper at the Stapleton's arms store, testified that his store sold 18 guns to citizens claiming to be members of the special police force. ${ }^{49}$ E.J. Watkinson, co-owner of the Dart \& Watkinson arms store, acknowledged that the demand for arms at his store was very great during the riot and that he sold $\$ 1,198$ worth of arms and ammunition to policemen and citizens. ${ }^{50}$ Therefore it seems clear that the riot produced a spontaneous and tremendous demand for arms and that the sales probably amounted to hundreds of pistols. This suggests that the riot was not carefully planned days or weeks before, as some supporters of the convention alleged.

On July 30,1866 , the night of the riot, Henry C. Warmoth wrote in his diary that the general impression among Union men was that the attack was premeditated and "that the City government planned it, as it is certain they executed it." 51 The reports of the Military Commission and the Congressional Investigating Committee show that supporters of the convention as well as the military authorities agreed with that conclusion. 52 In doing so, however, they ignored important circumstantial evidence and overlooked the fact that on the morning of the 
riot the mayor had published a proclamation asking the people to avoid creating any disturbance by staying away from the place where the convention was to meet. Nor did they take into account the fact that Lieutenant Governor Voorhies went to the offices of all the city papers asking them to publish editorials to the same effect. They based their conclusion merely on other circumstantial evidence: the discrepancy between the number of wounded and killed on both sides, the close collaboration between the police and the mob during the riot, the immediate arrival of the police on the scene of the riot following the ringing of an alarm bell, the presence of many fire companies, the numerous threats made before the riot, the presence of the city police wearing arms despite a city regulation to the contrary, the appointment of Lucien Adams, a thug of ill-fame, to the police force only a week before. They pointed out that only convention supporters and blacks were arrested, and claimed that citizens allegedly wearing either badges, ribbons, or handkerchiefs wereproof of conspiracy, to say nothing of the rumor that the Hays' Brigade, a former Confederate unit, was in force in the riot, and the appearance of a Confederate lieutenant in full uniform. ${ }^{53}$ Although those facts could easily support the theory that the riot was planned, it is important to remember that this theory also furnished the military authorities with an explanation that relieved them of any responsibility, while it provided the conventionists and the blacks with an invaluable cause célèbre that they could use to influence Congress and Northern public opinion in their favor.

The theory that a massacre was planned and executed by the city authorities has to be rejected. First, no clear and indisputable evidence exists to support it. Second, Mayor Monroe and Lieutenant- 
Governor Voorhies, not only vehemently denied the charge, but had openly acknowledged before the riot that if any disturbance occurred they would be the losers. 54 Third, Col. Adams, chief of police, and several police officers testified that the only orders given were not to interfere in any way with the convention, but to maintain peace and order. 55 Finally, Voorhies had already arranged with General Baird to have the conventionists arrested by Sheriff Harry T. Hays, and this was sanctioned by President Johnson. 56

However, if the view of a conspiracy on the part of the civil authorities must be dismissed, the failure of the police to do their duty must be explained. A look - the list of casualties shows without any doubt that the police force lamentably and tragically failed to fulfil its proper role. The evidence shows not only that the conventionists and their supporters would not have resisted arrest, 57 but that the police could have driven back the crowd, cleared the street, and prevented most of the bloody events of the riot. ${ }^{58}$ still, not all police officers misbehaved. Many conventionists, both black and white, acknowledged that their lives were saved by policemen. 59 The fact that ${ }_{\Lambda}^{\text {no }}$ fewer than 293 blacks and 31 white supporters or conventionists were arrested and brought to the city jails supported the view that not all policemen behaved brutally or irresponsibly. ${ }^{60}$ As E.P Brooks of the New York Times wrote on the day of the riot:

The police behaved, as a general rule, with extraordinary bravery and extraordinary cruelty. Probably 50 of them were wounded, several mortally. They were nearly all doubly armed, and used their arms with great effect and indiscriminate execution. As I have before remarked, some of them did their duty in protecting their prisoners, and all the prisoners who are now alive owe their lives to this fact. The mob would have lynched every white man in the building and brutally murdered 
every black man, had it not been for a few gallant and chivalric policemen. From what I have already said, however, you must know that some of the force were the worst rioters present. . 61

The fact that the police as a body behaved so badly may be explained, though not excused, by recognizing that they were working under the extreme pressure and influence of the white mob, with which they strongly sympathized and whose views on the convention they shared. It is not surprising, then, that the police quickly got very excited and out of control, a fact that was noticed by several witnesses. ${ }^{62}$ And it must not be forgotten that the police were fighting for their jobs, ${ }^{63}$ and that they were convinced that the other side was the riotous element. Those circumstances help to explain the failure of the police force, a failure which had such tragic consequences.

Although the theory of a conspiracy by city authorities may be dismissed, many white citizens were determined to "do their duty," as they put it, and disrupt the convention by force if necessary. The threats issued before the riot, the increasing tension in the city caused by the reconvening of the convention, the rumors circulating in the city during the weekend previous to the riot, and the gathering of the crowd on the morning of July 30 , are facts that cannot be overlooked. Several conventionists were aware of the probability of trouble, as was General Sheridan, while a week before the riot E.P. Brooks refused to accompany General Sheridan on his journey to Texas because he believed a riot was coming. 64

On the other hand, the blacks who flocked to the Mechanics' Institute were perhaps equally determined to uphold the convention, and seemed to have been organized for that purpose. This is shown by the 
presence of at least two former captains, three former lieutenants, and two former sergeants of the U.S. colored troops among a black crowd of whom almost half had served in the Union army. Moreover, the formation of a procession headed by a drum, a fife, and a Union flag and partially armed with guns and clubs reveals a certain seriousness of purpose, to say the least. In no uncertain terms they were answering the call of Dr. Dostie to go to the Institute and demand their right to full citizenship.

Although military authorities claimed that the city police could have quelled the riot, it was difficult for them to justify the absence of troops once they had agreed to send some. General Baird acknowledged that Voorhies visited him at his headquarters on the morning of the riot and during this meeting he had offered Voorhies to post troops close to the Mechanics' Institute one hour before the convention met, which seemed to please the Lieutenant-Governor. Baird stated also that immediately after Voorhies left, a little before 12:00 P.M., he issued an order to that effect. Baird further reported that it should have taken from 30 to 45 minutes for the troops at Jackson Barracks, three miles from Canal street, which had been put on alert on Sunday, July 29, to make their way to Canal street. 65 Although both General Baird and Lieutenant-Governor Voorhies disagreed on the hour of their meeting, Baird stating that they met at 11:00 A.M., while Voorhies reported that it was at 10:00 A.M. ${ }^{66}$ still there was ample time from 11:00 A.M. or even 12:00 P.M., for the troops to arrive before the riot began. And yet the troops did not arrive until after 3:00 P.M., probably closer to 4:00.67 Baird attempted unsuccessfully to explain the discrepancy between 30 to 45 minutes which were needed, and the four to five hours 
it took for the troops to arrive. First, Baird said that the delay was due to the fact that the troops were to be brought by a steamer and that "probably the officer in command was ignorant of the current of the river."68 Second, Baird stated that he had the impression that the convention was to meet at 6:00 P.M., although he was unable to explain how he got this impression. That Baird did not know the exact hour the convention was to meet is particularly strange, since he acknowledged that he read the morning papers of July 30; if so, he must have known, as everybody else in the city knew, that the convention would assemble at noon. Baird was in fact either grossly ignorant, or he failed most grievously as commanding officer of the Louisiana Department, for it was his duty to follow closely events that could threaten the peace and tranquility of his department. It seems more likely that he perverted the facts to excuse his inaction. The only conclusion possible is that either Baird did not send an order to the troops at 11:00 A.M. to move immediately to Canal street, as he had agreed with Lieutenant-Governor Voorhies to do, or he omitted, contrary to what he stated, to put the troops at Jackson Barracks on alert and to arrange to have a steamer ready for them there on Sunday, July $29 .^{69}$ But General Baird could not acknowlege that without admitting his incompetence or confessing to neglect of duty.

Baird's inaction is understandable, although it was inexcusable. He acknowledged that he read in the papers of the morning of the riot the Proclamation of Mayor Monroe, to which was annexed Johnson's telegram to Voorhies, which the latter showed Baird later in the morning, informing him that "the military will be expected' to sustain, and not obstruct or interfere with the proceedings of the courts." 70 Baird testified that 
he had no doubt about the authenticity of the telegram, and yet he falsely stated that he did not know if the president expected the military to sustain Judge Abell, who opposed the convention, or Judge Shannon, who supported it. ${ }^{71}$ In fact, Baird knew what the president desired him to do, but he also knew that he would be blamed by the Northern press and Congress if he did it. Baird simply did not want to get involved in a political situation in which he could burn his fingers. As General Sheridan clearly stated in his order before he left for Texas, Baird knew that he must avoid siding or seeming to side with either faction, because the military authorities would immediately be blamed and accused of partiality. Consequently, knowing the explosive division between the President and the Congress, and the repercussions that the Louisiana question could have in Washington, General Baird was reluctant to interfere. General Baird was not a radical, ${ }^{72}$ but he knew that Thomas W. Conway, the former assistant commissioner of the Freedmen's Bureau, had been removed for being too radical, while General J.S. Fullerton, who had superseded Conway temporarily, had been harshly criticized in the North for being too lenient toward the conseratives and ex-Confederates. It will be recalled that Baird himself had been strongly attacked by the Northern press and had received a reprimand from General Howard in November 1865 for having continued Fullerton's orders in force. ${ }^{73}$ It is not surprising, under those circumstances, that Baird desired to stay out of the question of the reconvening of the convention, while he considered the police force and the city authorities amply competent to maintain order. But what General Baird did not see is that he had already interfered when he limited the power of the civil authorities, whom he held responsible for keeping the peace, by 
requiring his approval before they arrested any of the conventionists. Consequently, the general shared a large part of the responsibility for the events of July 30. From any point of view, Baird had been tried and found wanting.

The way General Sheridan dealt with the convention question casts a shadow on his character and reputation. Sheridan left for Texas on JuIy 23 , although he had received notices, before he left, that the New Orleans press was publishing inflammatory articles concerning the Convention. 74 He specified further that he had given orders to General Baird before he left "that he [Baird] was not to allow the military to become involved in any political discussion or matter that kind; that he was not to allow the military to be used for the support or objects of either party" and that "the military were not to be used, except in case of a breach of the peace" 75 . Sheridan stated further that he had several discussions with Baird on that subject and that he was very particular in giving those instructions. He explained his reasons: "If he had, in anticipation of a riot, placed troops in the Mechanics' Institute, he would have been charged with supporting the Convention and supporting a political body. Such a charge would, undoubtedly, have been made against him, and be might have lost his command."76 Further, E.P. Brooks, reporter of the New York Times, testified that he declined the offer of Sheridan to accompany him to Texas because he expected a riot. ${ }^{77}$. The view that Sheridan expected trouble in which he did not want to be involved is further supported by his promulgation of Order No. 14, which dissolved all organizations of ex-Confederates that had been formed since May 1866 as charitable associations. ${ }^{78}$ This order was issued on July 22, the same day he informed General Rawlins of his 
decision to go to Texas. ${ }^{79}$ Futhermore, he had written to Rawlins on June 5, 1866, expressing his fears concerning the formation, as charitable organizations, of the Hays Brigade, the Gibson Brigade, the Washington Artillery, and the Fenner Battery in the City of New Orleans. Sheridan stated that "it should not be forgotten that in case of riots which the military might be forced to put down, that instead of fighting a mob we would find organizations, and in much greater numbers than we have troops here". Sheridan went further by asking General Rawlins to allow him "to order the Huse battery from the Rio Grande to this City so that we might not be entirely helpless in case of disturbance". Finally, Sheridan concluded that he would have not allowed the formation of those organizations, but since they had been allowed in Virginia and other places, he did not want to make an issue of $i t^{80}$. It is interesting that he changed his mind about these "charitable" associations only on the eve of his departure for Texas, and only after having given specific orders to General Baird on the policy to follow in case of a disturbance. Sheridan had justified his trip to Texas on the vague pretext of French threats, although he had himself in the same letter acknowledged that he doubted the ability of the French to withstand the onrushing Federal Mexican troops, which had already liberated Matamaros and all the northern provinces of Mexico during June ${ }^{81}$. Under those circumstances, it seems likely that Sheridan's real reason for going to Texas was to avoid any personal involvement in the scabrous question of the Convention.

By the morning of July 30 , all conditions were present to make a collison between supporters and opponents of the convention inevitable. New Orleans was acting out on a small scale the tragedy of Reconstruction. The tragedy, indeed, of the nation. 
Notes for Chapter VI

${ }^{1}$ New Orleans Picayune, July 31, 1866.

2Report of the Grand Jury of the Parish of Orleans (hereinafter cited as Grand Jury Report), New Orleans Public Library, Archives, 4, 6; "Military Report, Testimony," 136.

3"Military Report, Testimony," 19, 31, 32.

4 "Military Report, Testimony," 136.

5 "Military Report, Testimony," 19, 31, 32, 136; "Grand Jury Report", 5, 6, 10.

6"Military Report, Testimony," 19, 31, 32, 136; "Grand Jury Report", 5, 6, 10.

7 "Military Report, Testimony," 29, 137-8; "Congressional Report, Testimony," 12, 29, 43, 77; New Orleans Times, July 31, 1866.

8"Military Report, Testimony," 29, 137-38, 164; "Congressional Report, Testimony," 12, 29, 43, 77, 147.

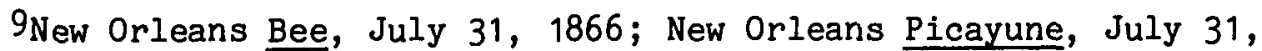
1866; New Orleans Times, July 31, 1866.

10 "Congressional Report, Testimony," 18, 20, 71, 75, 85-6, 103, 253, 254, 296, 382, 383; "Military Report, Testimony," 7, 11, 33, 37, $48,90,112,138,180,186,187,188,199,235,285,325,377,386-7$, 459, 477; "Grand Jury Report", 3, 4, 5, 9, 10, 11; New Orleans Bee, July 31, 1866; New Orleans Picayune, July 31, 1866; New Orleans Times, July 31,1866 .

11 Thibaut denied that he was the flag bearer, but only a bystander; See "Military Report, Testimony," 368.

12 "Congressional Report, Testimony," 18, 20,71, 75, 85, 86, 103, 253, 254, 296, 382, 383; "Military Report, Testimony," 7, 11, 33, 37, $48,90,112,138,180,186,187,188,199,285,325,377,386,387,459$, 477; "Grand Jury Report", 3, 4, 5, 9, 10, 11; New Orleans Bee, July 31, 1866; New Orleans Picayune, July 31, 1866; New Orleans Times, July 31, 1866.

13"Military Report, Testimony," 138.

14 "Grand Jury Report", 3, 4, 5, 9, 10, 11; "Military Report, Testimony, " 7, 11, 33, 37, 48, 90, 112, 180, 186, 187, 188, 199, 235, 
285, 325, 377, 386-7, 410, 459, 477; "Congressional Report, Testimony," $18,20,71,75,85,86,103,125,253,254,296,382,383$.

15Nathaniel Burbank to R.H. Shannon, July 16, 1866 , letter sent, RG 393, Gulf Department, War Department; Provost Marshall Court Record, October 31, 1865, RG 105, BRFAL; New Orleans Bee, August 22. September 23, October 3, November 7, 1862, May 9, 10, 1863. July 17, 1866; New Orleans Times, May 13, July 3, 1864 , February 15, May 27, August 29, September 1, 15, December 22, 23, 24, 25, 27, 1865, March 26, 27, 1866; New Orleans Crescent, July 7, 1866; Southern Star, December 22, 23, 24, 25, 27, 1865, January 29, 1866; New Orleans Tribune, December 27, 1865, April 24, 1866.

16 "Congressional Report, Testimony," 2, 3, 7, 15, 17, 18, 35, 64, $68,80,91,93,124-25,171,198,207,208,215,327,332,445$.

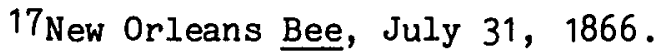

18"Military Report, Testimony," 417; "Congressional Report, Testimony," 68, 326.

19 "Congressional Report, Testimony," 78, 87.

20 It is impossible to determine whether or not he was acting on his own or as a provocative agent for the white crowd.

21 "Grand Jury Report", 4, 5, 7, 9, 10, 11; "Military Report, Testimony, " 12, 13, 20, 21, 25, 34, 75, 139, 142, 150, 373, 398, 410, 428, 447, 448; "Congressional Report, Testimony," 81, 118, 252-54, 266, $309,321,33,339,381$, 400; New York Tribune, July 31, 1866; New Orleans Bee, July 31, 1866; New Orleans Times, July 31, 1866; New Orleans Picayune, July 31, 1866; New Orleans Crescent, July 31, 1866; The description furnished by N.C. Snethen of the beginning of the riot corresponded exactly to the one given by General Herron, except for the fact that Snethen asserted that the first shot was clearly fired by a black, while Herron reported it was fired by whites. We have no doubt about the impartiality of either, which makes it difficult to determine who fired the first shot in the front of the Institute.

22 "Military Report, Testimony," 24, 181, 238, 280, 293, 300, 301, $332,338,339,345,351,362,366,369,370,371,384,388,390,407$, 442, 448, 474, 481, 485; "Congressional Report, Testimony," 2, 8, 12, $18,19,81,94,118,119,123,186,187$, and the like.

23 "Military Report, Testimony," 25, 30, 60, 61, 76, 78, 86, 96, $105,106,193,247,285,304,316,491$; "Congressional Report, Testimony," $8,12,29,35,36,64,65,70,79,87,94,96,97,103,118$, $119,120,123,125$, and the like; "Grand Jury Report", 4, 6, 7, 11; New Orleans Picayune, July 31, 1866; New Orleans Times, July 31, 1866.

24 The police knew of the charges presented by Judge Abell to the Grand Jury, the attempt made by Mayor Monroe to prevent military interference, the attitude of the press, which had pictured the conventionists 
as revolutionaries and agitators, and the feeling of the white community which opposed the project.

25 "Military Report, Testimony," 3, 19, 23, 31, 32, 35, 39, 85-88, $92-3,97,99,102,136,164,172,180,193,196,244,247,248,260$, $264,285,286,307,381,473,390$; "Congressional Report, Testimony, " 8, $12,18,29,35,3664,65,70,79,87,96-7,103,118-20,123,125,126$, $158,166,187,195,204,205,215,251,252,253,293,295,297,309$, $321,333,341,353,354,357,373,381,492,493$; "Grand Jury Report", $4,6,7,11$; New Orleans Times, July 31, 1866; New Orleans Picayune, July $31,1866$.

26 "Military Report, Testimony," 3, 19, 23, 31, 32, 35, 39, 85-88, $92-3,97,99,102,136,164,172,180,193,196,244,247,248,260$, $264,285,286,307,381,473,390$; "Congressional Report, Testimony, " 8, $12,18,29,35,3664,65,70,79,87,96-7,103,118-20,123,125,126$, $158,166,187,195,204,205,215,251,252,253,293,295,297,309$, 321, 333, 341, 353, 354, 357, 373, 381, 492, 493; "Grand.Jury Report", 4, 6, 7, 11; New Orleans Times, July 31, 1866; New Orleans Picayune, July $31,1866$.

27 "Military Report, Testimony," 5, 31, 37, 43, 45, 82, 89, 95 , $140,141,147,148,174,176,177,246,291,299,312,336,358,361$, $381,392-3,413,448,457,476,480,496,502,511,515$; "Congressional Report, Testimony," 12, 65, 87, 103, 160, 178, 191, 199, 203, 266.

$28_{\text {New }}$ Orleans Picayune, July 31, 1866.

29 New Orleans Picayune, July 31, 1866; Baird to Secretary of War, July 30,1866 , in Johnson Papers, LC; no other trouble occurred on that day, except for a disturbance at about 11:30 at night when some blacks, at the corner Enghenin and Port streets, according to the Picayune, fired at several citizens passing in the street. Nine blacks were arrested, and one was shot dead by the police.

30 "Congressional Report, Report," 11-16; "Congressional Report, Testimony," 176-77, 181-86; "Military Report, Testimony," see documents at the end of the report.

31 "Military Report, Testimony," 15, 16, 65, 157, 416; "Documents," see list of policemen wounded presented by Thomas E. Adams, chief of police; see also Report of Lt-Governor Voorhies, Attorney General Herron, and Mayor Monroe, to the President, August 3, 1866, Johnson Papers, (also in New Orleans Picayune, August 7,1866 ). See also New Orleans Bee, July 31, August 2, 8, 1866; New Orleans Picayune, July 31, August $1,5,7,1866$.

32Chicago Tribune, August 8, 1866; New York Times, August 8, 1866.

33"Congressional Report, Testimony," 14, 31, 48, 81, 144, 159, 166, 206, 335, 478; "Military Report, Testimony," 65; J.C. Houzeau, "Le Joumal Noir," 110.

${ }^{34} \mathrm{New}$ Orleans Picayune, July 31, 1866. 
35"Congressional Report, Testimony," 478.

${ }^{36}$ Ibid.; see also testimony of J.B. Jourdain who reported that many were killed and buried without the knowledge of their friends or families (Congressional Report, Testimony, 206). The report of Dr. Hartsuff declared that only two white supporters of the convention were killed, while there were three, Dr. Dostie, Capt. Loupersen, and Reverend Horton.

37w. M. Caskey, Secession and Restoration, 228; New Orleans Bee, July 31, 1866; New Orleans Picayune, July 31, 1866.

$3842.5 \%$ of the blacks involved in the riot had served in the US colored troops.

39"Grand Jury Report", 9.

40 "Military Report, Testimony," 51; "Congressional Report, Testimony," $373,385,498$.

41 "Military Report, Testimony," $30,37,70,75,80,100,124,142$, $163-4,174,190,192,215,258,286,340,411,457,462,479,491$.

42"Military Report, Testimony," 11.

43Sheridan to Johnson, August 6, 1866, telegram received, Johnson Papers, LC; Sheridan P.H., Personal Memoirs of PH Sheridan, 238.

44 "Military Report, Testimony," 124, 234, 264; see also note 10.

450 rder General No. 62, October 28, 1865, Scrapbook of Order received and issued, RG 393, Gulf Department, War Department.

$46_{\mathrm{Lt}-G o v e r n o r}$ Voorhies testified that a city regulation prohibited police officers from carrying firearms (Military Report, Testimony, 424). For police armed and orders given to the police, see "Military Report, Testimony, " 5, 6, 10, 14, 15, 42, 46, 67, 133, 144, 151, 156, $164,267,307,321,387,413,424,430,441,457$; "Congressional Report, Testimony," 9, 12, 19, and the like.

47 Those big gun stores were: A.B. Grimswold \& co. on St-Charles st.; Hyde \& Guttridge, corner Royal and Canal St; House of H. Folson \& co.; and Stapleton's arms store. See "Congressional Report, Testimony," 187, 188, 357; "Military Report, Testimony," 209, 271, 274, 275, 277, $278,281,384,385,426,430,449,453,466,467,468,506$.

48 "Military Report, Testimony," 274.

49 Ibid., 468.

${ }^{50}$ Ibid., 272.

51 Warmoth diary, July 30,1866 , Warmoth Papers, UNCA. 
52 "Congressional Report, Testimony," 19, 24, 30, 49, 79-80, 129, $131,140,201,202,203,219-21,396-7,440-460$; "Military Report, Testimony," 91, 154, 351, 434; Testimony of Sheridan in Congressional Report, 348; sheridan to Grant, August 1, 1866, telegram received, War Department.

53"Congressional Report, Report," 16-17; "Military Report, Report,"; N.Y. Tribune, October 3, 1866.

54 "Military Report, Testimony," 419, 432-4, 452; "Congressional Report, Testimony," 236-7, 442, 457.

55 "Military Report, Testimony," 5, 6, 10, 14, 15, 42, 46, 156, $387,424,430$.

56 "Military Report, Testimony," 419, 432-4, 452; "Congressional Report, Testimony," 236-7, 442, 457.

57 on the morning of the riot, several conventionists had held a formal meeting and agreed that they should not resist if attempts were made to arrest them, but that they should apply to Judge Guy Duplantier of the 6th City District Court to be immediately released under a writ of habeas corpus (see "Military Report, Testimony," 218, 377; "Congressional Report, Testimony," 408). Moreover, George Clark, a member of the City Council, acknowledged that if the conventionists and blacks had had any intention of committing "any act of resistance, they could have hurt a great many outside" (Military Report, Testimony, 402). For other evidences: see "Congressional Report, Testimony," 4, 10, 19, 29, 31, $38,41,47,55,65,67,218,377,408,464$.

58 "Military Report, Testimony," 252.

59 "Congressional Report, Testimony," 12, 64, 123, 214-5; "Grand Jury Report", 5, 6, 7; "Military Report, Testimony," 5, 31, 37, 43, 45, $82,89,95,98,141,147,148,149,174,176,177,246,299,312,381$, $392,459,474,496,502,511$.

$60_{\mathrm{New}}$ York Times, August $8,1866$.

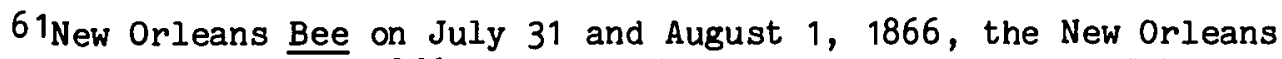
Crescent on August 1, 1866, and the New Orleans Picayune on July 31, 1866, did publish a list of blacks and whites arrested. The list did not include any member of the white mob, although Thomas E. Adams testifed before the Grand Jury that he had 10 to 12 young boys arrested for acting viciously. He increased this number to 50 in his testimony before the Military Commission. See Grand Jury Report, 14; "Military Report, Testimony," 14-16.

62 "Military Report, Testimony," 38, 108, 113, 152, 174, 238-9, $242,274,285$.

$63 \mathrm{~A}$ new force had been appointed in May 1866, following the City election of March 1866. A change of the political situation would have meant that most of the police force would have been discharged, and 80 
percent of the police force was discharged after the March 1866 city election. 4,000 people applied for the 500 positions in May 1866. See New Orleans Picayune, May 3, 1866.

$$
\begin{aligned}
& 64 \text { "Congressional Report, Testimony," 17, } 350 . \\
& 65 \text { "Congressional Report, Testimony," 449, } 452 . \\
& 66 \text { "Congressional Report, Testimony," 237-8, 464-5; "Military }
\end{aligned}
$$

Report, Testimony," 421-2, 475-6; Lieutenant Louis Cazarc, aide-de-camp to General Baird testified that Voorhies came at 10:45 and left after a few minutes.

67 General Baird stated that the troops arrived on the scene of the riot at 2:40, but this contradicted by the New Orleans press's description of the riot on July 31 which situated the arrival of troops at 4:00 P.M. This late hour is further confirmed by Jacob Barker who wrote to Johnson on July 31 that the troops arrived only at $3: 35$, by the correspondent of the Cincinnati Gazette and by A.L. Lee, a Union general, who was in New Orleans at the time of the riot. See Barker to Johnson, July 31, 1866, Johnson Papers, LC; New Orleans Bee, July 31, 1866; New Orleans Picayune, July 31, 1866; New Orleans Times, July 31, 1866; Chicago Tribune, August 8, 1866; New Orleans Times, July 31, September $18,19,1866$.

68 "Congressional Report, Testimony," 449.

${ }^{69}$ Ibid. , 458.

$70_{\text {Ibid. }}$

71 Ibid. , 459.

72C.R. Comstock to General Rawlins, February 3, 1866, Baird Miscellaneous Papers, War Department, National Archives.

73Max Woodhull, Asst. Adj. Genl., to General A. Baid, November 24, 2865, Registered of Letter received, Assistant Commissioneer, BRFAL.

74 "Congressional Report, Testimony," 350.

75 Ibid. , 348-50.

76 Ibid. , 350 .

77 Ibid. , 17 .

78 Those Confederate organizations were holding on each Saturday a public meeting. See New Orleans Crescent, May, June, 1866; For Order no. 14 of General Sheridan, see New Orleans Crescent, July 23, 1866.

79 Sheridan to Rawlins, July 22, 1866, Grant correspondence, War Department, National Archives. 
${ }^{80}$ Sheridan to Rawlins, June 5, 1866, Sheridan Papers, LC.

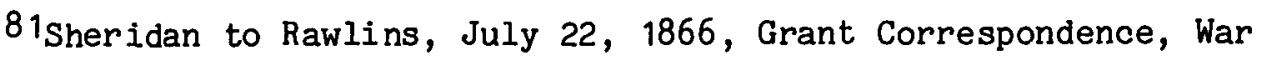
Department, National Archives. 


\section{CHAPTER VII}

Crowd and Mob: a World without Class Distinction

The New Orleans riot has usually been presented as the consequence of an attempt by Louisiana Radicals to return to power by revising the state constitution so as to enfranchise the black population. Confronted with this projected coup detat, the civil authorities used the city police, not to break up the convention, but to maintain order by arresting the rioters. However, the police got out of hand, and with the help of a reckless white mob composed mainly of teen-agers and of the rabble of the city, they attacked a band of poor deluded Negroes who, urged on by unprincipled white men, had converged on the Mechanics' Institute to express their support for the convention. This timehonored conservative interpretation needs to be revised.

Traditional historians, such as John R. Ficklen, Francis P. Burns, and William M. Caskey describe the conventionists as Radicals who were not interested ${ }_{n}^{\text {in }}$ universal suffrage unless it happily coincided with their desire to obtain "the plums of office through negro votes." ${ }^{1}$ For different reasons, historians such as Roger Shugg, Fawn Brodie, and Donald Reynolds ${ }^{2}$ also see the conventionists as Radicals. On the other hand, Joe Gray Taylor presents them as Unionists, while Michael L. Benedict sees them as constituting an alliance of "conservative Louisiana unionists, as Hahn, Cutler, Field and Dostie--and other members of the old Banks-Hahn machinery--. . . with their erstwhile radical enemies in 
a desperate attempt to regain power." ${ }^{3}$ An analysis of the political affiliation of the conventionists and their supporters should throw some light on this confused subject, especially on the question of Radical participation. 4

Although only 25 conventionists answered the roll call at 12:00 p.m. on July 30 , the list of those arrested or wounded reveals that at least 32 of the 96 conventionists of 1864 showed up at the Mechanics' Institute. Of those, 20 had held public office during the war, 20 had been elected to the 1864-1865 legislature, and 17 had attended the Conservative Union convention of October $1865 .^{5}$ Moreover, 26 of 32 had both held office and had served in the 1864-1865 legislature, indicating that a desire to regain office was a factor in their appearance at the meeting on July 30. This conclusion is strengthened by a close look at the political antecedents of those who attended the meeting of June 26 , preliminary to the reassembling of the convention: 33 of the 39 had held office or had been members of the legislature. Thus of those who attended either the June 26 or the July 30 meeting, 38 out of 44 were either former officholders or former members of the legislature.

of the 96 delegates who sat in the constitutional convention of 1864, only eight had afterwards associated themselves, in some cases rather tentatively with the Radicals. Ernest J. Wenck had signed the petition of December 1864 opposing the readmission of Louisiana as a state; W.R. Hire, Robert W. Bennie, Joseph Dupaty, Endaldo G. Pintado, and Charles Smith had been delegates at the Republican Convention of September 1865. Meanwhile, Charlie Smith had also joined Joseph G. Baum and Louis Gastinel in signing the December 1865 petition for admission 
of Louisiana as a Territory. Robert W. Bennie did not attend either the June 26 or July 30 meeting, while Joseph G. Baum and Louis Gastinel went only to the June 26 meeting. As for the other five, Joseph Dupaty and Endaldo G. Pintado went only to the July 30 meeting, while W.R. Hire, Charles Smith and Ernest J. Wenck attended both meetings. However, of those seven delegates who showed support for radical ideas and for the reconvening of the 1864 convention, five had previously held office or had been members of the legislature, which could indicate that they had some personal interest in the reconvening of the convention.

The character of the white unionists who supported the conventionists reinforces the impression given by traditional historians such as Ficklen that the main issues were offices and political power. of the 96 whites $^{6}$ who showed their support for the conventionists by appearing at the Mechanics' Institute, only 33 percent had, then or earlier, an upper or middle-class occupation (See Table VII.1). At least 38 had been officeholders or had run for of fice at the legislative elections of 1864 and 1865 or at the city election of 1866 . Combining that list of 96 whites with the list of 95 others who attended the July 27 meeting produces a total of 166 different individuals. Of those 166 white supporters, 71 (43 percent) had formerly held or had run for public office.

Only 16 of those 166 whites had previously been associated with the radicals. ${ }^{7}$ Moreover, those 16 persons represented only a small fraction of the 99 radicals. 8 of those 16 radicals, only three played a major role in the Republican party, and of those three, two, W.R. Crane and H.C. Warmoth, did not support the convention but did go to the 
Table VII. 1

Occupation of the White Supporters at the Riot

Occupation Number Relative $\%$ Adjusted $\%$

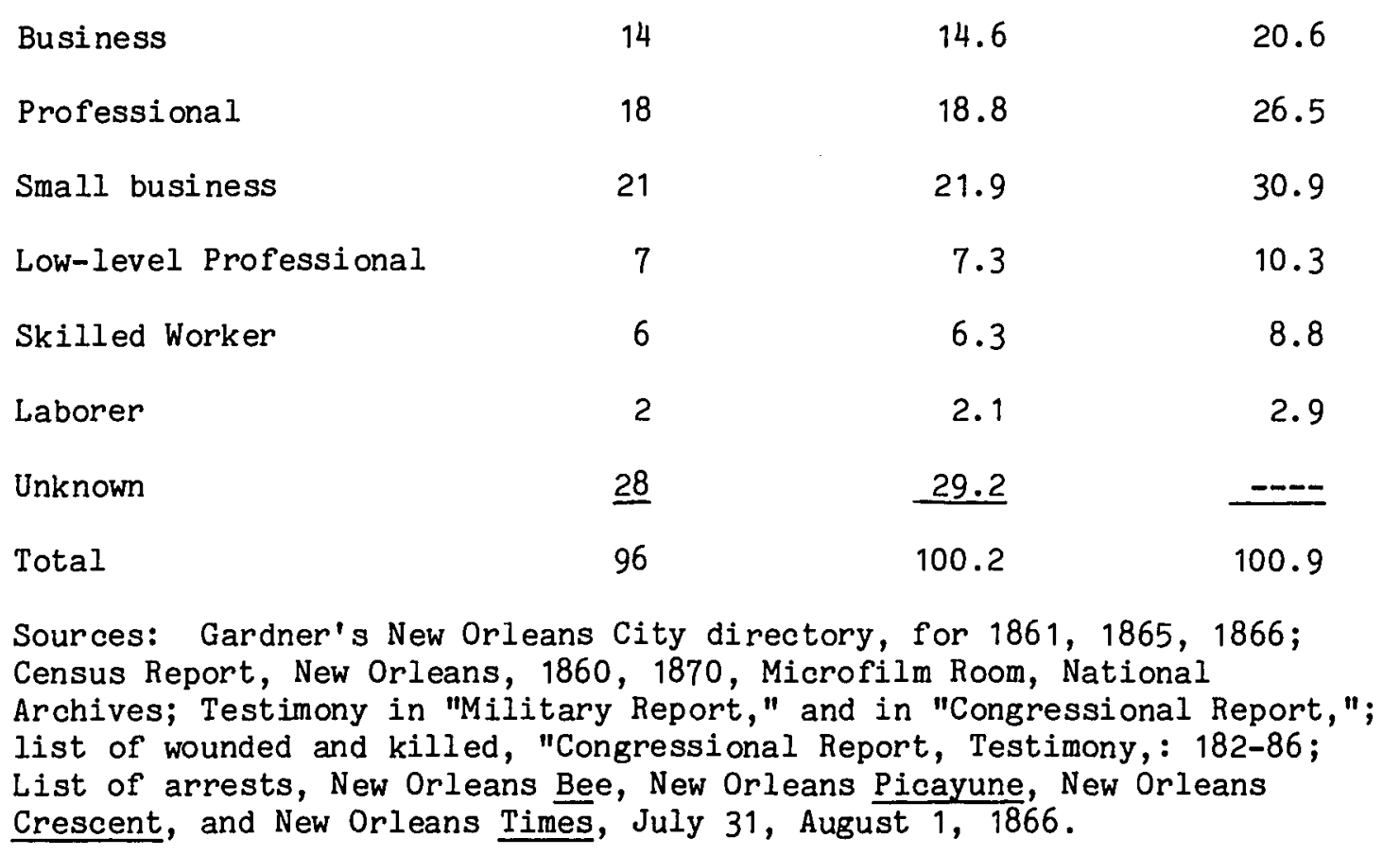

Mechanics' Institute as observers, while only Rufus Waples gave enthusiastic support to the conventionists' scheme. Five others, Louis B. Collins, R.F. Daunoy, Henry C. Dibble, Guy Duplantier, and J.F. Mollere are considered Radicals only because they signed the petition of December 1865 for the admission of Louisiana as a Territory. Three others, Alphonse Delage, Victor E. Rillieux and Dr. Auguste Shelly, had supported Radical views by participating in the Repubican Convention of September 1865 ; but A. Delage's radicalism is suspect because he was a 
member of the 1864-1865 legislature, while Auguste Shelly had by winter 1865-1866 given his support to the movement despite the opposition of most radicals to unite all the Union forces. The last five, Charles B.H. Duplessis, Frank Duplessis, Joseph Duplain, G.H. Houghton, and Charles Renaud were more Unionists than Radicals, since they had either only attended the Durant meeting of February 11, 1864, and had afterwards been candidates under the Conservative Union banner at the election of November 1865. In conclusion, the evidence proves that the whites who supported the reconvening of the 1864 convention were, except for a few, not members of the Radical party and had not previously held Radical opinions; a large number, however, had held office under Governor Hahn and expected to regain their jobs by supporting the convention.

Hitherto historians have not only drawn an inaccurate picture of the convention movement but have paid little attention to the blacks, who suffered most from the riot. Historians of the Dunning school, such as Ficklen, Burns, and Caskey, did not comment on the character of the blacks at the riot, although they probably would have agreed with the conservative press, which described them as freedmen fresh from the plantations. ${ }^{8}$ Two later historians, W.S. McFeely and R.D. Connel, are more specific. McFeely described the black procession as a parade of Negro workingmen, and Connel assumed that a large number of free black leaders participated in the riot. ${ }^{9}$ still the social origin of the blacks involved in the riot needs to be determined in order to draw a complete picture of that event.

Using the New Orleans press, which published a detailed list of the 293 blacks arrested during the riot, and the reports of the Military 
Commission and the Congressional Committee that investigated the riot, it is possible to gather information about 360 blacks who were involved in the riot. ${ }^{10}$ But in order to draw a more complete picture, it is necessary to include all blacks who had participated in social or political organizations between 1863 and 1866. This furnishes a sample of 532 blacks, 242 blacks who were free before the war and 290 others. ${ }^{11}$ Out of the 360 blacks counted as present at the riot, at least 126 were free blacks. Of the 532 blacks about whom information was collected, 195 ( 36.6 percent) had served in the Federal army, and of those, 153 (78.5 percent) showed up at the riot and constituted 42.5 of the blacks involved in the riot. Charles W. Gibbons, a former black officer, testified before the Congressional Committee that 40 to 50 black former members of the First Native Guard were in the procession that marched to the Institute. 12

Previous political or social activity was not as important a factor as military service. Of the 205 blacks who could be identified as playing an active social or political role between 1863 and 1866,13 only 31 ( 15.6 percent) appeared on the scene of the riot, and those 31 blacks represented only 8.9 percent of the blacks present. This number would be even lower if one excludes 12 free blacks whose only action was to sign a petition in 1864 demanding suffrage for the free black population. This lack of participation is a clear indication that the blacks who were politically involved tended to follow the position adopted by the Central Executive Committee of the Republican party which had refused to endorse the reconvening of the convention and who had encouraged the blacks to do the same. ${ }^{14}$ 
A study of the occupation and social status of the blacks present at the riot shows that they were scarcely the crowd of ignorant ex-slaves depicted by the Conservative press. Out of the 198 whose occupations could be established, 57 could be described as unskilled, 32 had carpentry skills, 10 mechanical skills, 14 trades connected with shipping, 17 clothing skills, 20 housekeeping skills; 22 had risen to the mid-level professional class, and 26 belonged to the mercantile community (See Appendix II). A closer look at some of the blacks involved in the riot shows that more than 13.3 percent of them came from the "best element" of the black community. Francois Lacroix, a former tailor who owned property worth $\$ 250,000$ in 1860 and $\$ 1,000,000$ in 1874 , attended the convention meeting and lost a 16 year old son in the riot. Bernard Soulie, a commission merchant with property valued at $\$ 100,150$ in 1860 , testified that he went to the Mechanics' Institute as an observer. John F. Seapring, a sailmaker worth $\$ 25,500$ and John Sparring worth $\$ 22,150$ were also at the riot, while Arthur L. Thibaut, a commission merchant and former lieutenant in the 73 rd US colored infantry was said to be the flag bearer of the black procession. 15

As in the case of the conventionists and their supporters, black and white, historians have not made a serious analysis of the social origins of the white wob who tried to break up the convention. Ficklen concludes that the mob was composed of the ruffianly and reckless elements of the city, but does not present any substantial evidence other than the testimony of Edward P. Brooks, the correspondent of the New York Times. Donald E. Reynolds, basing his conclusion on the statement of Richard Taylor, Confederate lieutenant general and son of President Zachary Taylor, and on the testimony of John Leclarc and George W. New, 
a merchant, before the Congressional Committee, assumes that "a large number of teen-ager youths" had joined a mob composed of "firemen wielding wrenches, bands of ex-Confederate soldiers, workers from nearby shops, and just plain rabble." ${ }^{16}$ Reynolds concludes, in a passage reminiscent of Ficklen that "conservative leaders did not fear the Convention, though they disapproved of it and tried to suppress it by legal means," while "many lower class citizens were not disposed to consider whether or not the convention could really achieve its objectives; it was enough for them that Radical whites and Negroes were meeting together and proposing measures, which if ever carried out would destroy the whole fabric of their stratified social system." 17 Except for Francis P. Burns and Joe Gray Taylor, who acknowledged that a large portion of the white mob was composed of firemen, ${ }^{18}$ no other historian has attempted to furnish a detailed description of the white mob.

To agree with Richard Taylor that the white mob was largely one of teen-agers would deprive the riot of much of its significance. In fact, at least four different witneses testified that crowds of boys were present on the scene of the riot. ${ }^{19}$ Other witnesses, however, stated that the white mob was not composed mainly of boys, but of many young Confederate veterans. ${ }^{20}$ Still other witnesses testified to the presence of citizens but did not report having seen any boys. ${ }^{21}$

From the testimony of a reliable witness, such as John L. Leidner, Chief of the New Orleans Fire Department, it is possible to conclude that many firemen appeared on the scene of the riot after the general fire alarm had sounded. 22 Chief Leidner acknowledged that fire companies $6,10,18$, and 20 went to the riot, while other witnesses 
reported having seen firemen from companies $2,5,10,12,14, \frac{\text { ald }}{21}$ as well. This would mean that firemen from at least 9 out of the 25 city fire companies were present at the riot. ${ }^{23}$

Supporters of the convention quickly charged that the presence of fire companies at the riot was a part of a plan by the city authorities to break up the convention. 24 Their allegation was partially confirmed by the New Orleans Bee, which reported on July 31 that the Fire Department had been ordered to assemble after the riot had begun and to be ready to intervene and support the police if necessary. Likewise P.A. Cazeaux, a clerk and telegrapher at Treme police station, testified that secret orders were given to the Fire Department to support the city police. 25 on the other hand, Chief J.L. Leidner testified that no orders were given to the Fire Department to collaborate with the police, but was unable to explain why so many companies hastened to the riot. Leidner acknowledged that the general alarm calling the fire department was 20 bells, while on July 30 , only 12 bells were heard. ${ }^{26}$ Given the chaotic course of the riot and the unorganized response of the police, the most likely explanation for the presence of so many firemen is not that they received any central directive but that on hearing the 12 bells alarm they rushed to the Mechanics' Institute on their own initiative. This view is also strengthened by the testimony of E.P. Brooks, the correspondent of the New York Times, and George Clark, a City alderman, who said the general alarm bell was not intended for the Fire Department but as a way to call the city police to the scene of the riot. 27 
Although many young men and firemen did appear in the front of the Mechanics' Institute during the riot, the white mob was not necessarily composed only of the lower social elements of the city. Although J.B. Jourdain, a free black cigar maker, testified before the Congressional Committee that the white mob consisted mainly of lower class whites, 28 Lucien P. Capla, a free black shoemaker, partly contradicted Jourdain and said that several citizens working with the mob were very well dressed, while others came from the very lowest class. ${ }^{29}$ Other witnesses reported the presence of large number of clerks, and the New Orleans Tribune said that wealthy people sent their clerks to the riot. ${ }^{30}$ Moreover, the fact that large quantities of arms and ammunition were bought by the "best class" of people when the riot broke out imples that the rioters were not only lower class people. ${ }^{31}$ Meanwhile, the Chicago Tribune, a militant Republican paper, charged on August 8, 1866, that "elegantly appearing persons, assuming the selective places in the aristocratic society of the city, leaped upon the lifeless bodies of prevously murdered men as they lay on Canal Street." 32 Fortunately, this fragmentary and conflicting evidence can be supplemented by examining a sample of 55 whites who were recognized as having been involved in the riot. 33 This sample represents less than 10 percent of the whites reported as present at the riot. Since some witnesses could have acted from personal spite in reporting the names of persons who were in fact not at the riot, and because prominent people were more likely to be noticed than plain "rabble", one must be cautious in drawing conclusions.

Of those 55 white rioters, three were described as poor, two as laborers, six as skilled workers, seven as firemen or watchmen, twenty 
as either clerks, reporters, or civil servants, one as a grocer, one as a druggist, ten as either lawyers, merchants, bankers, or real estate owners, and three as students (See Table VII.2). But a close look at the sample shows that J.W. Overall, personal secretary to Mayor Monroe, five members of the city council, and George Clark, an insurance broker, city alderman, former Acting Mayor, $a_{n}^{\text {nd }}$ former member of the Secession Convention, all acted with or encouraged the mob in its bloody behavior. George Ruloff, a merchant and banker worth more than $\$ 100,000$, and his son were also on the scene of the riot. Furthermore, several witnesses reported that Captain James Phillips, a member of the Legislature, an ex-planter and law partner of the prominent Louisiania lawyer, Christian Roselius, was an active member of the mob. Others were Captains Frederick Brooks, owner of a restaurant and a large boarding house, E.H. Cenas, the son of Dr. A.H. Cenas, a professor at Louisiana State University, the only known white victim on the side of the mob, Henry Clark, a clerk and son of George Clark, Edward B. Ehrenhardt, an attorney and notary public, and John McCleland, a former Chief of the city police under the administration of Mayor Monroe in 1861 and 1862. ${ }^{34}$ Moreover, the sample shows that a large number of those whites had served in the Confederate army, but only two had been in the Union army, one of whom was Thaddeus P. Mott, a former U.S. Colonel discharged by a court martial (See Table VII.3).

Historians have paid very little attention to the character of the New Orleans city police. 35 Several witnesses before the Military Commission and Congressional Committee testified that two-thirds to three-fourths were ex-Confederate soldiers, while others claimed that in May 1866, Mayor Monroe had made service in the Confederate army an 
Table VII.2

Occupation of Members of the White Mob

\begin{tabular}{lcc}
\multicolumn{1}{c}{ Known-Occupation } & Number & Percent \\
Poor & 3 & 5.7 \\
Laborer & 2 & 3.8 \\
Skilled Worker & 6 & 11.3 \\
Fireman, Watchman & 7 & 13.2 \\
Student & 3 & 5.7 \\
Clerk, Reporter, Civil Servant & 20 & 37.7 \\
Grocer, Druggist & 2 & 3.8 \\
Lawyer, Merchant, Banker & 10 & 18.9 \\
Total & 53 & 100.0
\end{tabular}

Sources: "Congressional Report, Testimony"; "Military Report, Testimony"; New Orleans Picayune, July 31, 1866; Gardner's New Orleans City Directory, for 1861, 1865, 1866; Census Reports, New Orleans, 1860, 1870, Microfilm Room, National Archives.

important requirement for an appointment to the police force. Thomas $\mathrm{E}$. Adams, a former colonel in the Confederate army and the chief of the city police in the summer of 1866 , stated that Mayor Monroe controlled the appointment of the police force and that about two-thirds came from the ranks of the Confederate army. Mayor Monroe was forced to admit to the Military Commission that more than half of the force had served the Confederacy. ${ }^{36}$ A study of Monroe's appointments reveals that 281 (56.3 percent) of 499 police officers about whom information was 
Table VII.3

Civil War Service of Members of White Mob

Service

Confederate army

Union Army

Unknown

Total
Number

32

2

$\underline{21}$

55
Percent

58.2

3.6

38.2

100.0

Sources: Index of the troops from Louisiana serving in the Confederate army, Microfilm Room, National Archives; Index of the troops from Louisiana serving in the Union army, Microfilm Room, National Archives; "Congressional Report, Testimony"; "Military Report, Testimony"; New Orleans Picayune, July 31, 1866.

collected served either in the Confederate army or in the Confederate Louisiana Militia. 37

It could be argued that 56 percent is a low figure since about 75 percent of the southern white male population of military age served in the Confederate forces, ${ }^{38}$ and 44 percent of the delegates in the 1864 convention had also served under the Confederacy. But the main charges against Mayor Monroe stemed from the fact that he fired the police force that had just been hired by Acting Mayor George Clark and appointed a new one. ${ }^{39}$ Although Mayor Monroe did reappoint 50 to 60 percent of the police officers who had been previously hired by the Acting Mayor, he did in fact discriminate against Unionists. Only 74 ( 14.8 percent) of the policemen appointed by Mayor Monroe had served on 
the force during the war, ${ }^{40}$ while at least 135 (27 percent) of the Monroe police had served on the police under the Know-Nothing administration of 1858 to 1862 (See Table VII.4).

Table VII. 4

Previous Service of the Monroe Police of 1866

Previous Service

Police officer before the war

Police officer during the war

Police officer before and

during the war

Unknown

Total
Number

110

49

25

$\underline{315}$

499
Relative \%

22.0

9.8

5.0

63.1

99.9
Adjusted \%

59.8

26.6

13.6

Sources: New Orleans Bee, and New Orleans Picayune, July 1857, July 1858, June, July 1859, May 28, 31, 1862; New Orleans Crescent, May 28, 1866; New Orleans Picayune, May 29, 1866; 1865 roll call of the New Orleans City police, New Orleans Public Library.

The fact that so many police officers had previously served under Monroe's administration before the war provoked charges that he was attempting to return to the old Know Nothing days of the 1850s, when thugs had joined the police force in large numbers, and had, by threats, violence, and murders terrorized the population and controled the city administration. 41 In response to such allegations, the New Orleans Crescent, the state and city printer, defended the Mayor's policy:

Was it strange that when Mr. Monroe became mayor of the city he appointed his officers from among his friends and not among his enemies--that he constituted the police mainly of those who were, in fact, a portion of the real people or New Orleans, and not of those who, having always been opposed to the sentiment 
of this community both in peace and in war, cannot decently claim to represent it? Was it strange that his appointees were chiefly members of that National Democratic party by which he was nominated and elected? Was it wonderful that among them were many of those men with maimed limbs or empty sleeves, who have a right to ask service at the hands of a community by which they were sent forth to fight and bleed and suffer? By no means. Had Mr. Monroe acted otherwise than as he did, he would have been guilty of treachery towards the party which elected him, of ingratitude towards the friends who supported him, and of faithlessness towards the people who had just bestowed on him so conspicuous a mark of their confidence. 42

Not al? the Conservative papers agreed with the Crescent or supported Monroe. The Picayune charged that the city police did not represent the "best class" of people and stated that the population of New Orleans was grossly deceived and defrauded by the appointment to the police force of "drones, drunkards, worthless and broken down characters" while it paid $\$ 400,000$ a year for the support of the police. The Picayune concluded that "the old custom of making the police department the last refuge of broken down and worthless characters, who have failed at everything else, and cannot support themselves at any honest employment, must be discarded." 43 A study of the occupation or social origin of the members of the police force appointed by Mayor Monroe reveals that they mostly came from the lower class (See Table VII.5).

Even if the theory that the city authorities conspired to break up the convention is rejected, Mayor Monroe still shared a large part of the responsibility for what occurred at the riot, given the character of the police force that he appointed. However, in order to give a complete picture of the character of the police force, it is necessary to recall that when the New Orleans police force was reorganized in the spring of 1866, Monroe was confronted by the fact that, not only had a third of the former police force signed a protest against his election, ${ }^{44}$ but also 
Table VII.5

Occupation of the Monroe Police Force

\section{Occupation}

Laborer

Skilled Worker

Firemen, watchman

Clerk, bookkeeper

Teacher

Liquor store, grocer, small dealer

Lawyer, doctor

Merchant.

Harbor Master

Total
Number

91

45

16

35

1

18

3

1

1

211
Percent

43.1

21.3

7.6

16.6

0.5

8.5

1.4

0.5

$\underline{0.5}$

100.0

Sources: New Orleans Crescent, May 28, 1866; New Orleans Picayune, May 29, 1866; Gardner's New Orleans City Directory, for 1861, 1865, 1866; Census Reports, New Orleans, 1860, 1870, Microfilm Room, National Archives.

that more than 4000 people applied for the 500 positions on the police force. This last point is particulirly important because it revealed the high level of chronic unemployment at that period. ${ }^{4}$ Monroe would naturally choose as police officers not those who opposed his election, but those who supported him.

The main conclusion to be drawn from this study of the social origins and occupations of the different groups involved in the riot is that, 
except for the police force, none of them could be described as belonging mainly to the lower classes. Each level of the social strata of the city was represented at the riot. Finally, this study demonstrates clearly that, in spite of what historians have said, radicals, whether black or white, were conspicuously absent from the scene of the riot. 
Notes for Chapter VII

1Francis P. Burns, "White Supremecy in the South: The Battle for Constitutional Government in New Orleans, July 30,1866," Louisiana Historical Quarterly, XVII, (July 1935), 596-97; W.M. Caskey, Secession and Restoration, 212, 219-20; J.R. Ficklen, History of Reconstruction in Louisiana, 155, 162-3.

2F.M. Brodie, Thaddeus Stevens: Scource of the South, (New York, 1959) 273-80; Donald E. Reynolds, "New Orleans Riot of 1866, Reconsidered," $6,7,8,12,14,16,21,25,27$; Roger W. Shugg, Origin of Class Struggle in Louisiana, 216.

3J.G. Taylor, Louisiana Reconstructed, 104, 107, 110; M.L. Benedict, A Compromise of Principles, Congressional Republican and Reconstruction, 1863-1869, 204.

"The term "Radical" is used to describe a person who supported or openly advocated universal suffrage and civil equality for blacks and who had either attended the Durant meeting of February 11, 1864, signed the Radical petitions of December 1864 and December 1865, attended the Republican Convention of September 1865, or had been a member of the Freemen's Aid Association.

5It is not necessary to present again the occupations of the conventionists; for details see Appendix $I$.

6 The list of 96 was compiled from the list of those whites arrested or wounded at the riot and from the list of those who testified before the Congressional Committee and Military Commission.

7 This is not to imply that Radicals did not want to hold office, but it is obvious that to be a radical and to advocate universal suffrage and civil equality for blacks made it difficult for the same man to hold an office throughout the period 1863-1866. When in office, Governor Hahn favored only his friends, and when he was succeeded by Governor Wells, the new governor removed even moderates that he found too radical. Therefore the advocacy of universal suffrage kept a radical from holding office except under the federal administration (Treasury Department).

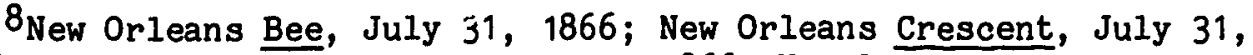
1866; New Orleans Picayune, July 31, 1866; New Orleans Times, July 31, 1866; see also Grand Jury Report, 14.

9R.C. Connel, "The Forgotten People: the Free People of Colored in New Orleans," 243; W.S. McF eely, Yankee Stepfather, 283. 
${ }^{10}$ New Orleans Crescent, July 31, 1866; New Orleans Times, July 31, 1866; New Orleans Picayune, July 31, 1866; "Military Report, Documents,"; "Congressional Report, Testimony," 182-186.

11 We consider as free blacks only those about whose status information could be found; see 1860 census, New.Orleans; Gardner's New Orleans City Directory, 1861, Free black petition of January 1864 , Legislative Documents, National Archives. It is important to note that only four black women were either wounded or arrested at the riot.

12 "Congressional Report, Testimony," 125; The accuracy of the Gibbons' testimony is verified by the fact that at least 34 blacks, formerly of the 73rd US colored infantry (previously known as the First Native Guard) were at the riot.

13 The list of 205 blacks who had played an active social and political role was drawn from the petition of free blacks for suffrage (we took only the names of those who had been either involved in the riot or in some other activity), from the black meeting (National Equal Rights League) of September 1865, the black convention of January 1865, from the committee for the reception of Chase, from the Executive Committee of the Freedmen's Aid Association of 1865 and 1866, Prom the "Freres Unis" committee of April 1866, and from the Committee on celebration of Emancipation on May 1866, and from the participants list at the Civil Rights meeting of May 1866. See National Archives, Legislative Document, petition of free colored people for suffrage, January 5, 1864; New Orleans Tribune, September 16, 17, 1864, January 9-15, May 12, 23, September 17, 24-30, 1865, March, April, May, 1866.

14 "Congresssional Report, Testimony," 7, 42, 70, 292-4, 440; New Orleans Crescent, July 12, 24, 1866; New Orleans Times, July 21, 1864.

15 The facts are drawn from 1860 and 1870 census and from R.D. Connel, "The Forgotten people," 300-6. Connel demonstrates clearly that census returns and tax lists tended to underestimate the wealth of the free black population of New Orleans, either because of racial bias, or because some wealthy free blacks tended to "understate their holdings to intrusive census takers." Connel, 110-115.

$16 \mathrm{~J}$. R. Ficklen, History of Reconstruction in Louisiana, 163, 168. Richard Taylor, Destruction and Reconstruction, edited by Richard B. Harwell, (New York, 1955) 304-5; "Congressional Report, Testimony," 92, 168; Donald Reynolds, "New Orleans Riot of 1866," 12.

17Donald Reynolds, "New Orleans Riot of 1866," 27.

18F.P. Burns, "White Supremacy in the South," 613; J.G. Taylor, Louisiana Reconstructed, 108.

19"Congressional Report, Testimony," 92, 168; "Military Report, Testimony," 68, 175.

20 "Congressional Report, Testimony," 180, 327; "Military Report, Testimony," 198, 215. 
21 "Military Report, Testimony," 34, 91, 123, 381, 417.

22 "Military Report, Testimony," 540-544.

23"Congressional Report, Testimony," 68, 80, 94, 110, 115, 119, $143,157,172,180,195,196,205,206,207,213,281,327,353$;

"Military Report, Testimony," 117, 173, 176, 205, 240, 346, 370, 381 , $480,487,497,500,503,510,529,530,537-544$.

24 "Congressional Report, Testimony," 68, 80, 94, 110, 115, 119, $143,157,172,180,195,196,205,206,207,213,281,327,353$; "Military Report, Testimony," 117, 173, 176, 205, 240, 346, 370, 381 , $480,487,497,500,503,510,529,530,537-544$. 549-50.

25 New Orleans Bee, July 31, 1866; "Military Report, Testimony,"

26 "Military Report, Testimony," 540-544.

27 "Military Report, Testimony," 497; "Congressional Report, Testimony," 353.

28 "Congressional Report, Testimony," 208.

29 "Congressional Report, Testimony," 123; It is possible that inembers of the mob dressed themselves in lower class clothes to conceal their social status, as happened at the New York riot of 1863 . E.P. Brooks, the correspondent of the New York Times, reported that the whole city was in a commotion, and that the white mob was composed of men of every class. (see New York Times, August 8, 1866).

30 "Military Report, Testimony, 183, 267, 290; New Orleans Tribune, October, 1866.

31 "Military Report, Testimony," 274, 468. The fact that so many guns were sold, while it cost around $\$ 15$ a piece to buy a pistol and while $\$ 15$ in New Orleans of 1866 meant a week of work for a worker, this tends to prove conclusively that citizens who bought firearms had to be of middle or upper class.

32 Chicago Tribune, August 8, 1866.

33The sample was drawn mainly from the testimony of witnesses before the Military Commission and Congressional Committee investigating the riot. They are the only sources available, since no list of white rioters arrested exists.

34 "Congressional Report, Testimony," 37, 68,93-1!, 98, 135, 178, $187,188,193-96,199,204,248,310,354,365,401,476,493-99$; "Military Report, Testimony," 66, 79, 83, 85, 134, 143, 167, 195, 245, $248,254,261,267,286-7,311,327-9,338,339,345-6,354,369,380$, $389,391,397,408,411,427,464,466,480,507,530,537$; New Orleans Picayune, July 31 1866; Gardner's New Orleans City Directory, for 1861, 
1865, 1866; Census Reports, New Orleans, 1860, 1870, Microfilm Room, National Archives.

35 Except for Fawn M. Brodie who depicted them as ex-rebels; Thaddeus Stevens, 274.

36 "Military Report, Testimony," 155, 156, 255, 427, , 551; "Congressional Report, Testimony,": 5, 32, 67, 80, 95, 106, 408, 484-7.

$37 \mathrm{~A}$ list of the police appointed by Mayor Monroe was published in the New Orleans Crescent of May 28, 1866, and New Orleans Picayune, May 29, 1866. The percentage was derived from a comparison of this list with the Index of the troops from Louisiana serving in the Confederate army, Microfilm Room, National Archives.

${ }^{38}$ Ludwell H. Johnson, Division and Reunion, (New York, 1978), 87.

39Acting Mayor Clark appointed a police force in early May; a partial list of members was published in the New Orleans Times, May 5, 12,1866 , and New Orleans Picayune, May 9, 1866.

40 Another example of discrimination against unionists occurred in August 1866 when the School Board, now in the hands of ex-Confederates, appointed only 139 teachers who were on the teacher list of 1865 and selected 82 new ones. Between 1863 and 1865, 90 percent of the teachers were reappointed, while it dropped to 62.9 percent between 1865 and 1866. See New Orleans Times, September 23, 1863, August 17, 1866; New Orleans Picayune, September 26, 1865; New Orleans Crescent, August 31, 1866. See also "Congressional Report, Testimony," 239, 392, 399, 427.

41 "Congressional Report, Testimony," 5, 10, 15, 22, 38-9, 42, 67, $78-9,95-6,121,137,139,206,208,494,499,520$.

42New Orleans Crescent, July 23, 1866.

43New Orleans Picayune, July 22, 1866.

${ }^{44}$ Petition to General Canby, March 16, 1866, M. 1738, letters, received RG 393, Gulf Department, War Department, compared with the roll call of 1865 New Orleans City police, in New Orleans Public Library.

45 There were 12,600 electors in New Orleans in May 1866. The 1864 constitution required citizens who appled for a position on the police force to be residents of the city and registered voters. The fact that a third of the city's registered voters did apply in April and May 1866 for a $\$ 80$ a month position on the police force indicates the seriousness of the unemployment in the city. See New Orleans Tribune, May 3, 1866; New Orleans Picayune, May 3, 4, 1866. 


\section{Chapter VIII}

Conclusion

July 30,1866 , was a frightful day, one of the darkest in New Orleans' history. On that day, fanaticism, violence, and senseless cruelty swept the city. The riot lasted only some three hours, and yet in this short time it took a heavy toll: forty to fifty dead, and one hundred fifty to three hundred wounded. To modern Americans who have heard stories about mobs lynching blacks in the South in the first half of this century and who have lived through the race riots of the $1960 \mathrm{~s}$, the New Orleans riot may seem to be only one more incident in the long history of racial violence. But in 1866, the New Orleans riot, coming after the Memphis riot of May 1866 and the Charleston riot of June 1866 , had a greater significance. To many Northerners, not yet recovered from the trauma and shock of the Civil War, the riot gave plausibility to Republican charges of an unrepentant and still rebellious South.

The New Orleans riot, which occurred only three months before the crucial congressional elections of 1866, was swiftly exploited by the Republican press and became a central issue in the campaign. On August 27, 1866, Senator James Dixon of Connecticut wrote President Johnson that the administration was unjustly accused in regard to the riot and that the radicals were attempting to excite popular opinion and make capital of it through the press. ${ }^{1}$ Several Northern papers, following the view of the New York Tribune, had pictured Dostie as a soldier of liberty and presented the riot as the beginning of a reign of terror in 
the South, as a new St. Bartholomew massacre in which loyal unionists were brutally murdered by former rebels. Those papers boldly charged that President Johnson was mainly responsible for this sad event, that his policy had "engendered the spirit which broke in riot." Some papers published exaggerated or fictitious descriptions of the riot. ${ }^{2}$ Moreover, President Johnson did not help his cause during his tour though the North in September 1866, when he unwisely denounced Congress and charged that some of its members had their hands red with blood from the riot. ${ }^{3}$ All this contributed to the Republican triumph in the elections, which enabled the party to seize control of Reconstruction and overthrow the policy of Lincoln and Johnson.

Most historians have recognized the importance of the New Orleans riot in bringing about radical, or congressional, reconstruction. They have pointed to the emotional storm it produced in the North, the influence it had in enlarging the gulf between the President and Congress, the role it played in the congressional elections of 1866 , and finally the impetus it gave to the passage of the Reconstruction Act of March 1867. They have also recognized the inherent irony of the New Orleans riot, the ultimate consequence of which was to bring the very changes that New Orleans whites had attempted to prevent by rioting. The riot expressed both the unwillingness of the men in power to be displaced by a small group of Unionists and the refusal of the great majority of whites to accept the enfranchisement of blacks. Paradoxically, the riot, more than any other factor, played a major role in producing these changes, and more. Within two years after the riot, Louisiana'government was in the hands of Republicans, under a new constitution which recognized the equality of blacks, granted them equal suffrage, opened 
to them the highest state, city and parish offices, and prohibited discrimination. 4

A local disturbance, which the New Orleans riot was in reality, could not have had such consequences if it had not corresponded in some way to the views and interests of each of the parties involved, if it had not confirmed their convictions as to the social and political situation in the South and the remedy required to deal with it. A reading of the Northern and Southern press, and an examination of the different reports and investigations of the riot reveal that each party involved developed an interpretation of the riot designed to fit its particular ideological orientation, social values, and political interest. The Republican press and congressmen were convinced more than ever that the South had not accepted its defeat, that it was determined to resume the war under new leaders and in a new form. President Johnson, irritated by congressional opposition to his conciliatory policy, assumed that he was the victim of a radical conspiracy. The northern Democratic press and congressmen believed that the Republicans were ready to use any means to ensure their control of the national government, even if it meant Africanization of the South. Southern conservatives shared the view of the northern Democrats. Finally, southern radicals, white and black, concluded that their security, their fate, and their hope for a better and more just society rested in the hands of Congress. ${ }^{5}$ This entrenchment of each party in its narrow provincial or ideological views was deepened by the riot and probably was its most important result, because of the part it played in bringing on Radical Reconstruction. 
Historians, as well as contemporaries, have advanced conflicting views of the riot, and for a long time their views reflected, generally speaking, those that prevailed in the 1860s. The opposite poles of earlier interpretation are represented, on the one hand, by writers in the "Dunning school" of Reconstruction history, who believed that a Radical clique in Washington was responsible for the riot, and, on the other hand, by the famous Negro historian, W.E.B. DuBois, who was convinced that the city fathers deliberately planned and executed the riot. ${ }^{6}$ In recent years, the only new interpretation of the riot has been presented by Donald E. Reynolds, who assumed that the riot was the result of "a spontaneous explosion of racial antipathy on the part of the white mob," a view also accepted in the recent book by Joe Gray Taylor. Reynolds acknowledges that the conventionists had no chance to succeed and that the conservatives and the civil authorities knew it. Reynolds' explanation of the riot rests on the theory that "many of the lower class citizens were not disposed to consider whether or not the convention could really achieve its objectives; it was enough for them that the radical whites and Negroes were meeting together and proposing measures, which if ever carried out would destroy the whole fabric of their stratified social system." This interpretation might be more satisfactory if it were not for the fact that white radicals and blacks had already met together publicly more than once, had proposed measures for a new social order, and had even held a voluntary election to persuade Congress to accept their policies, all without bringing any "spontaneous explosion of racial antipathy." 7 In other words, Reynolds does not explain why the riot occurred on July 30 rather than any other day. The answer to this question lies in the disruption of the Louisiana political system. 
The immediate causes of the riot were the social tension and excitement provoked by the reconvening of the convention, the controversy over the Civil Rights bill, Judge Abell's charge to the Grand Jury, and the Friday night meeting. As Reynolds says, these events had created among the white population of New Orleans the fear that if the convention met, the whole social and poltical system would be destroyed. Still, this fear alone did not cause the riot. Such an outburst could occur only when the people had come to believe that the authorities, confronted with a danger that threatenedthe social order, were either unable or unwilling to do their duty. ${ }^{8}$ In the case of the New Orleans riot of 1866, white citizens, from the bottom to the top of the social strataj, became convinced that the city authorities and the civil courts, because of military interference, did not have the power or the capacity to act on their behalf. In a word, they believed that the conventionists had a chance to carry out their scheme and that it was the people's duty to interfere. A survey of the social and political history of New Orleans and Louisiana since the arrival of Union troops in 1862 could explain the origin and the development of that belief.

Since May 1, 1862, Louisiana had been under martial law; it had had no legitimate civil government at either the local or the state level. A civil government, with executive, legislative, and judicial branches, had been organized in 1864 , but this government was a creation of the military authorities and had never won congressional recognition. From its beginning that civil government was subject to the caprice of the commanding officer of the Gulf Department. Judges could be removed by military order, as occurred in July, 1864, when Judge W.W. Handlin declared void a military order about slavery. Military authorities 
could strip civil courts of jurisdiction over cases involving freedmen. They could declare void the black code passed by the Democratic Legislature. They forced Governor Wells to order a city election and then suspended the mayor-elect until he had journeyed to Washington to receive a presidential pardon. They dissolved private charitable associations organized by Confederates veterans, and so forth.

At the time of the riot, therefore, military authority was still supreme. And yet there was also a civil government, complete in all its parts, from the local to the state level, a government that was allowed to function within wide but ill-defined and fluctuating boundaries. Conflict and confusion inevitably arose over the precise line of demarcation between civil and military functions. This was partly the fault of military officials. During the period of 1862 to 1866 , no fewer than five different officers headed the Gulf Department, and each of them pursued a different policy in Louisiana. This lack of continuity and consistency encouraged the formation and spread of factionalism. In 1862 and 1863, the radical faction had flourished under the protection of Generals Butler and Shepley. When General Banks assumed responsibility for civil affairs in Louisiana in January 1864, he developed his own political machine and faction. Naturally there was great dissatisfaction among his supporters when he was temporarily superseded in September 1864 by General Hurlbut, who tended to support a more conservative faction. With the accession to the gubernatorial chair of LieutenantGovernor Wells in March 1865, General Hurlbut and the conservatives gained complete command of the political situation in Louisiana. However, their control lasted only until General Banks resumed command of the Gulf Department in April 1865. General Banks immediately began to 
undo the policy that Governor Wells and General Hurlbut had pursued. Banks' opposition forced Wells to call directly upon the President, from whom he obtained not only the removal of General Banks, but some restraint on the power of the military to interfere. Although the summer and fall of 1865 witnessed strong and bitter controversies between General Canby and Mayor Kennedy, the military authorities, squeezed between the civil government and the President, tended to adopt a neutral position and to let Governor Wells pursue his conciliatory policy.

The election of November 1865, which gave complete control of the state to the Democratic party, seemed to resolve the problem of factionalism. Instead, it was the beginning of a bitter rivalry between Governor Wells and the legislature, which quickly split over the questions of internal and national policy. When he discovered to his dismay that President Johnson sided with the legislature, Wells saw himself becoming a man without a party, a governor whout any power or influence. Consequently, he could support either Thomas J. Durant's radical Republican party, which called for congressional action, or he could throw his influence behind the Conservative Union party, the former Free State party of which he had once been a member, and encourage it to reconvene the 1864 convention. Wells took the latter course.

The decision of the old Hahn faction to reconvene the 1864 convention and the riot that followed showed in a tragic way the intense confusion that existed among the authorities in Louisiana in 1866. General Baird told civil officials that martial law and military regulations took precedence over any city regulations or state laws. Consequently, Baird, 
who had received directives from the War Department to protect tine rights of all citizens in his department, opposed Mayor Monroe's intention to disperse the convention by invoking city regulations and state laws banning unlawful assemblies. Up to this point, the attitude of the military authorities was quite clear; General Baird openly stated that martial law was paramount. But then, having denied the right of civil officials to arrest the conventionists, he failed to enforce his decision or to ensure the protection of the conventionists. Other than telegraphing Washington for advice, Baird did nothing. If Baird had either let the civil authorities act or if he had protected the convention, even with a small squad of troops, the riot could have been avoided.

Baird was not the only guilty party. His unwillingness to act resulted partly from his knowledge of the division between President Johnson and the congress over reconstruction. Unwilling to take the risk of being blamed by either side for acting on his own, Baird referred the case to Secretary of War Edwin M. Stanton. But the secretary of war, who was using any means to undermine Johnson's policy, did not reply to Baird or show his telegram to the President, for he knew that the latter would have backed the civil authorities. Stanton had given close scrutiny to the Memphis riot and its consequences, and it is difficult to escape the suspicion that what ensued in New Orleans was either surprising or unwelcome to him. In any apportionment of responsibility for the tragedy, the secretary of war must not be overlooked.

A comparative study of the Memphis and New Orleans riots reveals many similarities. Although both were race riots that stemmed from the 
opposition of whites to the assertive claims of blacks to certain rights, the main resemblance was the confusion of authority and the unwillingness of the military to interfere. In both cities, the riot occurred less than a year after the local population had elected a new city administration. In each case, the population elected the same officials who had served under the Confederacy until their removal by the Union commanders. Each new administration had appointed a new police force. In both cases, the civil authorities called upon the military authorities for troops to cooperate with the police force in maintaining order. In both cases, the city authorities quickly lost control of events and saw their police force openly sympathize and join with the white mob. In both cases, the riot ended with the arrival of the Federal troops. In New Orleans as in Memphis, the Freedmen's Bureau, whose main responsibility was to protect the freedmen, failed lamentably. The failure was particularly striking in the New Orleans riot, since'General Baird, who was both commanding officer of the Department of Louisiana and assistant commissioner of the Freedmen's Bureau, could have easily justified immediate intervention to protect the blacks. Baird had not drawn any lesson from the Memphis riot and was not ready to face the situation. In New Orleans as in Memphis, the riots revealed a confusion in determining who should act and the failure of the military authorities to meet their responsibilities. ${ }^{9}$

The unstable and confusing mixture of civil and military government that was an essential element in both riots was the local reflection of a national crisis. The Memphis and Louisiana riots occurred while President Johnson and Congress were dead-locked over reconstruction. Confusion and uncertainty were the consequences of this division within 
the national government, conditions that favored the growth of factionalism. In New Orleans, where factions had flourished under the management of political generals, each faction quickly sided either with Congress or with the President, in expectation of gaining support in their local struggle for power. By July 1866, it was not yet certain whether Congress or the President would be victorious. Under those circumstances, it is understandable, though not necessarily excusable, that the military authorities would be unwilling to do anything that could be construed as favoring either side in a dispute over reconstruction politics. In a word, the origin and the outcome of the New Orleans riot could not be separated completely from the national debate over Reconstruction. The division in the national government encouraged a burgeoning of factionalism and a paralysis of authority that led directly to the bloody denouement of July 30,1866 . The New Orleans riot was a grim and tragic illustration of the dilemma of a whole nation, the dilemma of Reconstruction. 
${ }^{1}$ Dixon to Johnson, August 27, 1866, Johnson Papers, LC.

2Chicago Tribune, August 2, 4, 6, 8, 1866; Harper's Weekly, August 18, 1866; The Nation, August 2, 9, 16, 30, 1866; New York Herald, August 2, 1866; New York Tribune, July 31, August 1, 2, 3, 31, 1866; see also editorials of the Boston Journal and Detroit Post quoted in the New Orleans Crescent of August 13, 1866, and the New Orleans Times of August 14,1866 .

3Eric L. McKitrick, Andrew Johnson and Reconstruction, 422-447.

"Francis P. Burns, "White Supremacy in the South," Louisiana Historical Quarterly, XVIII (July, 1935), 581-616; W.M. Caskey, Secession and Restoration, 204-231; W.E.B. DuBois, Black Reconstruction, 464-466; J.R. Ficklen, History of Reconstruction in Louisiana, 146-179; Eric L. McKitrick, Andrew Johnson and Reconstruction, 422-447; Donald E.

Reynolds, "The New Orleans Ri ot of 1866, Reconsidered," Louisiana

History, V (Winter, 1964), 5-27; Joe Gray Taylor, Louisiana

Reconstructed, $111-113,134$.

5"Congressional Report, Report," 1-63; Grand Jury Report, 1-2; Lieutenant Governor Voorhies, Attorney General Herron, and Mayor Monroe to President Johnson, August 3, 1866, Johnson Papers, LC, and also in New Orleans Picayune of August 7, 1866 and New Orleans Bee of August 8, 1866; Appleton Annual Cyclopaedya, 1866, pp 458, published by Appleton \& company, Vol. 6, New York, 1867; New Orleans Picayune, September 4, 1866; New Orleans Times, September 8,1866 ; see also Howard $K$. Beale, The Critical Year: A Study of Andrew Johnson and Reconstruction, (New York, 1930); W.M. Caskey, Secession and Restoration, 228-231; E.L. McKitrick, Andrew Johnson and Reconstruction, 439-447; J.G. Taylor, Louisiana Reconstructed, 111-113, 134.

6F.P. Burns, "White Supremacy in the South," 581-616; W.M. Caskey, Secession and Restoration, 204-231; J.R. Ficklen, History of Reconstruction In Louisiana, 146-179; W.E.B. DuBois, Black Reconstruction, 464-466.

7D.E. Reynolds, "The New Orleans Riot of 1866, Reconsidered," 5-27; J.G. Taylor, Louisiana Reconstructed, 104-111.

${ }^{8}$ Chalmers Johnson, Revolutionary Change (Boston, 1966; H. Otto Dahlke, "Race and Minority Riots--A Study in the Typology of Violence," Social Forces, XXX (May 1952), 419-25; Robert E. Park, On Social Control and Collective Behavior (Chicago, 1967); Lewis A. Coser, The Functions of Social Conflict (Glencoe, 1964); Neil J. Smelser, Theory of Collective Behavior (New York, 1962); Georg Simmel, Conflict and the Web of GroupAffiliations (Glencoe, 1955). 
${ }^{9}$ House of Representatives Report on the Memphis Riots and Massacres, Report No. 101, 39th Congress, 1st session, Washington, 1866; Jack D.L. Holmes, "The Effects of the Memphis Race Riot of 1866," West Tennessee Historical Society, XII (1958), 58-79; J.D.L. Holmes, "The Underlying Causes of the Memphis Race Riot of 1866," Tennessee Historical Quarterly, XVII (September, 1958), 195-221; Vincent L. Burns, "The Memphis Riot of 1866," M. A. Thesis, Memphis State University, 1972. 


\section{Appendix I \\ Occupation of 1864 conventionists}

Occupation

Working Class

- laborer

- carpenter

- skilled worker

- civil engineer
Number

15

5

3

5

2

Business

36

37.5

- General Dealer

- stock dealer, broker

- merchant

- coffee house

- grocer

- stables

35.4

- lawyer

- doctor

- teacher

- clerk

- shipping agent

- civil servant

17

6

1

5

2

2

Agricultural occupation

- farmer

2

- planter

1

Unknown

$-\quad \frac{8}{88}$

8.3

Total

88

96

Note 1: Totals do not equal $100 \%$ due to rounding.

Sources: Census Report, New Orleans, 1860, 1870, Microfilm Room, National Archives; Gardner's New Orleans City Directory, 1861, 1866; New Orleans Times, 1863 to 1866; New Orleans Picayune, 1863 to 1866; New Orleans Bee, 1863 to 1866; New Orleans Tribune, 1864 to 1866; Journal of the Convention for the Revision and Amendment of the Constitution of Louisiana, New Orleans, 1864. 
Appendix II

Occupation of the Blacks at the Riot

Occupation

Professional

- physician and dentist

- teacher

- minister

- reporter

- clerk, bookkeeper

- musician

Mercantile occupation

- merchant

- broker, accountant

- farmer

- coffee house, restaurant, saloon

- grocer

- small dealer

- cigars

Housekeeping skill

- steward

- housekeeper

- porter

- butcher

- oyster

- cook

- baker

\section{Clothing skill}

- tailor

- shoemaker

- turner

- dyer

- hatter

- dressmaker

- jeweller, watchmaker

- barber
Number

22

1

2

5

1

11

2
1

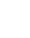

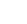

Relative \% Adjusted \%

6.1

11.1

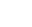


Occupation

Sea related skill

- rigger

- ship joiner

- sailmaker

- stevedore

- steamboatman

- mate

Mechanical skill

- foundryman

- screwman

- tinsmith

- telegraph operator

- engineer

- printer

Building, carpentry skill

- upholsterer

- carpenter

- painter

- caulker

- stonemason

- bricklayer

- cabinet maker

- moulder

Unskilled labor

- laborer

- drayman

- soldier

- grave digger

- blacksmith

- wood sawyer
Number

14

10

2.7

5.0
1

1

5

3
(1) (n)

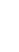

32

8.8

16.1

At Home

Unknown

Total
4

13

2

1

2

1 


\section{Bibliography}

\section{A: Manuscripts}

Historical Society of Pennsylvania, Philadelphia.

Chase, Salmon P. Papers.

Library of Congress, Washington, D.C.

Banks, Nathaniel P. Papers.

Butler, Banjamin F. Papers.

Chase, Salmon P. Papers.

Denison, George S. Papers.

Johnson, Andrew Papers.

Lincoln, Abraham Papers.

Stanton, Edwin M. Papers.

Stevens, Thaddeus Papers.

Louisiana Historical Society, New Orleans.

Wells, James M. Papers.

Louisiana State University, Department of Archives, Baton Rouge.

Flanders, Benjamin F. Papers.

Hahn, Michael Papers.

Maine Historical Society Library, Portland.

Shepley, George F. Papers.

Massachussetts Historical Society Library, Boston.

Quincy, Samuel M. Papers.

National Archives, Legislative and Judiciary Department, Washington, D.C.

Free Colored Petition for Suffrage to President Lincoln and Congress, January 5, 1864. 
National Archives, Treasury Department, Washington, D.C.

Civil War Third Special Agency Records, Record Group 366.

National Archives, War Department, Washington, D.C.

Baird, Absolom Miscellaneous Papers.

Bureau of Refugees, Freedmen and Abandoned Lands Records. Record Group 105.

Canby, Edward R.S. Miscellaneous Papers.

Civil Affairs, 1862-1866, Gulf Department, Record Group 393.

393.

General Correspondence, 1862-1866, Gulf Department, Record Group

Grant, Ulysses S. Correspondence.

Report and Proceedings of the Army Commission on the New Orleans Riot of 1866, Gulf Department, Record Group 393.

Report of the Smith-Brady Commission Investigating Corruption in the Gulf Department, Adjutant General Office Records, Record Group 94.

National Archives Microfilm Room.

Eighth Census Returns for New Orleans, 1860.

Index of the U.S. Colored Troops Serving during the Civil War.

Index of the Troops from Louisiana Serving in the Confederate Army, 1861-1865.

Index of the Troops from Louisiana Serving in the Union Army, $1861-1865$.

Ninth Census Returns for New Orleans, 1870.

New Orleans Public Library, New Orleans. 1867.

Gardner's New Orleans City Directory for the years 1861, 1866,

Register of Free Colored Persons Entitled to Remain in the State, 1840-1864.

Roll Call of the New Orleans City Police for the year 1865.

New York Historical Society Library, New York.

Durant, Thomas J. Papers. 
Minute Book of the Free State Association of New Orleans and City of Jefferson, 1863.

University of North Carolina. Southern Historical Collection, Chapel Hill.

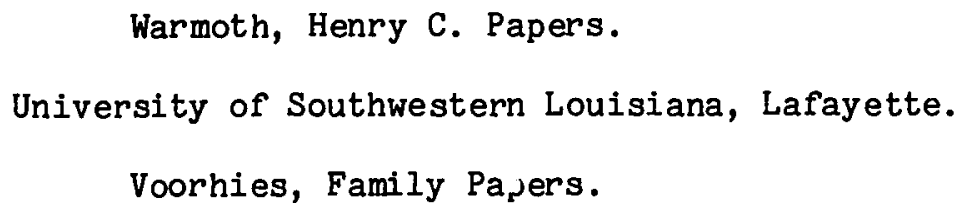


U.S. Senate Executive Documents, 39 Congress, 1 Session, No. 2.

U.S. Senate Miscellaneous Documents, 38 Congress, 2 Session, No. 2.

\section{C: Pamphlets}

Banks, Nathaniel P., "The Reconstruction of the States: Letter of Major General Banks to Senator Lane," New York, 1865.

Durant, Thomas J., "Letter to Henry W. Davis, October 27, 1864," H.P. Lathrop, New Orleans, 1864.

Warmoth, Henry C., "Letter of H.C. Warmoth, Claimant of a Seat in the House of Representatives as Delegate from the Territory of Louisiana, Addressed to Sdnator Williams of the Sub-Committee on Reconstruction for Louisiana," Washington, D.C. 1866.

Proceedings of the Convention of the Republican Party of Louisiana, New Orleans, 1865.

\section{D: Newspapers}

Chicago Tribune

De Bow's Review

Harper's Weekly

L'Union de la Nouvelle Orleans

New Orleans Bee

New Orleans Black Republican

New Orleans Daily Crescent

New Orleans Daily Picayune

New Orleans Southern Star

New Orleans Times

New Orleans Tribune

New Orleans True Delta

The Nation

New York Herald

New York Times

New York Tribune 


\section{E: Books}

Beale, Howard K. The Critical Year : A Study of Andrew Johnson and Reconstruction. New York, 1930.

Belz, Herman. Reconstructing the Union: Theory and Policy during the Civil War. Ithaca, NY, 1969.

Benedict, Michael L. A Compromise of Principles; Congressional Republicans and Reconstructions, 1863-1869. New York, 1974.

Blassingame, John W. Black New Orleans, 1860-1880. Chicago, 1973.

Capers, Gerald M. Occupied City: New Orleans Under the Federals, 1862-1865. Lexington, Ky, 1965.

Caskey, Willie M. Secession and Restoration of Louisiana. Baton Rouge, 1938 .

DuBois, W.E. Burghardt. Black Reconstruction in America. New York, 1962.

Ficklen, John R. History of Reconstruction in Louisiana. (Through 1868). Reprint. Gloucester, Mass. 1966.

Fisher, Roger P. The Segregation Struggle in Louisiana, 1862-1877. Urbana, Ill. 1974.

Gerteis, Louis S. From Contraband to Freedman. Westport, Ct, 1973.

Harrington, Fred H. Fighting Politician: Major General N.P. Banks. Philadelphia, 1948 .

Hesseltine, William B. Lincoln's Plan of Reconstruction. Tuscaloosa, Alabama, 1960.

McFeely, William S. Yankee Stepfather: General 0.0 . Howard and the Freedmen. New York, 1968.

McKitrick, Eric L. Andrew Johnson and Reconstruction. Chicago, 1960.

McPherson, James M. The Negro's Civil War. New York, 1965.

Reed, Emily. The Life of Anthony Paul Dostie Or the Conflict of New Orleans. New York, 1868.

Ripley, C. Peter. Slaves and Freedmen in Civil War Louisiana. Baton Rouge, 1976.

Shugg, Roger W. Origins of Class Struggle in Louisiana: A Social History of White Farmers and Laborers During Slavery and After. 1840-1875. Baton Rouge, 1939. 
Taylor, Joe Gray: Louisiana Reconstructed, 1863-1877. Baton Rouge, 1974.

Vincent, Charles. Negro Leadership in Louisiana, 1862-1870. Baton Rouge, 1975.

White, Howard A. The Freedmen's Bureau in Louisiana. Baton Rouge, 1970.

\section{F: Articles}

Burns, Francis P. "White Supremacy in the South: The Battle for Constitutional Government in New Orleans, July 30, 1866." Louisiana Historical Quarterly (July, 1935), 581-616.

Belz, Herman. "The Etheridge Conspiracy of 1863: A Projected Conservative Coup." Journal of Southern History (November, 1970), 549-67.

Capers, Gerald M. "Confederates -and Yankees in Occupied New Orleans, 1862-1865." Journal of Southern History (November, 1964), 405-426.

Carpenter, John A. "Atrocities in the Reconstruction Period." Journal of Negro History (October, 1962), 234-47.

Clarck, John G. "Radicals and Moderates on the Joint Committee on Reconstruction." Mid-America (April, 1963), 73-98.

Copeland, Fayette. "The New Orleans Press and Reconstruction." Louisiana Historical Quarterly (January, 1949), 139-337.

Dabney, Thomas E. "The Butler Regime in Louisiana." Louisiana Historical Quarterly (April, 1944), 487-526.

Engel smen, John C. "The Freedmen's Bureau in Louisiana." Louisiana Historical Quarterly (January, 1949) 145-244.

Everett, Donald E. "Demand of the New Orleans Free colored Population for Political Equality, 1862-1865." Louisiana Historical Quarterly (January, 1944), 43-64.

Hart, W.O. "The New Orleans Times and the New Orleans Democrat." Louisiana Historical Quarterly (October, 1925), 574-84.

Holmes, Jack D.L. "The Effects of the Memphis Race Riot of 1866," West-Tennessee Historical Society, XII, (1958), 58-79.

Holmes, J.D.L. "The Underlying Causes of the Memphis Race Riot of 1866," Tennessee Historical Quarterly, XVII, (September, 1958), 195-221.

Houzeau, Jean C. "Le Journal Noir, aux Etats-Unit, de 1865 a 1870." Revue de Belgique (May-June, 1872) 5-27, 101-126. 
Johnson, Howard P. "New Orleans Under General Butler." Louisiana Historical Quarterly (April, 1941), 434-536.

Lestage, H. Oscar. "The White League in Louisiana and Its Participation in Reconstruction Riots." Louisiana Historical Quarterly (July, 1935), 615, 695 .

Lowrey, Walter M. "The Political Career of James Madison Wells." Louisiana Historical Quarterly (October, 1948), 995-1123.

Messner, William F. "Black Violence and White Response: Louisiana 1862." Journal of Southern History (February, 1975), 19-38.

Perkins, A.E. "James Henri Burch and Oscar James Dunn in Louisiana." Journal of Negro History (July, 1937), 321-34.

Reynolds, Donald E. "The New Orleans Riot of 1866, Reconsidered." Louisiana History (Winter, 1964), 5-27.

Shugg, Roger W. "Suffrage and Representation in Ante-Bellum Louisiana." Louisiana Historical Quarterly (April, 1936), 390-406.

Taylor, Joe Gray, "New Orleans and Reconstruction." Louisiana History (Summer, 1968), 189-208.

Uzee, Philip D. "The Beginningss of the Louisiana Republican Party." Louisiana History (Summer, 1971), 197-211.

\section{G: Unpublished Theses and Dissertations}

Baker, Dorothy M. "An Economic Survey of New Orleans During the Civil War and Reconstruction." M.A. Thesis, Tulane University, 1942.

Binning, Francis W. "Henry Clay Warmoth and Louisiana Reconstruction." Ph. D. Dissertation, University of North Carolina, 1969.

Burns, Vincent S. "The Memphis Riot of 1866." M. A. Thesis, Memphis State University, 1972.

Connel, D.R. "The Forgotten People: Free People of Color in New Orleans, 1850-1870." Ph. D. Dissertation, John Hopkins University, 1976.

Constantin, Roland P. "The Louisiana 'Black Code' Legislation of 1865." M. A. Thesis, Louisiana State University, 1956.

McCrary, J. Peyton. "Moderation in a Revolutionary World: Lincoln and the Failure of Recontruction in Loulsiana." Ph. D. Dissertation, Princeton University, 1972.

Tregle, Joseph G. "Thomas J. Durant: Unionism as the Heir of Utopian Socialism", Paper presented at the meeting of the Louisiana Historical Association on March 9, 1978. 


\section{Gilles Vandal}

Born in Ste-Thecle, Quebec, on December 22, 1949. Graduated from Seminary des Sts-Apotres, Cote Ste-Catherine, June 1967, and D.E.C. from College St-Jean Vianney, Montreal, Quebec, June 1969. The author taught history at Seminaire Ste-Therese, Yaounde, Cameroun, 1969-1971. A.B., February 1974, and M.A., October 1975, at University of Ottawa, Ottawa, Ontario. The author was admitted as Ph. D. candidate at the College of William and Mary in Virginia in June 1977. 